\section{A III02 145783}

NAT'L INST OF STANDARDS \& TECH R.I.C

|||||||||||||||||||||||||||||||||||||||||||||||||||||||

I.|.|.|.|.

A11102145783

Dorfman, Leon M/Reactivity of the hydrox
QC100.U573 V46;1973 C.1 NBS-PUB-C 1973

\section{NBS}

PUBLICATIONS

NSRDS-NBS 46

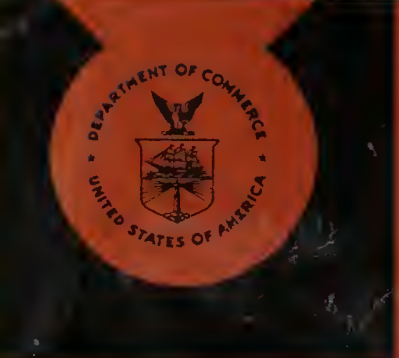

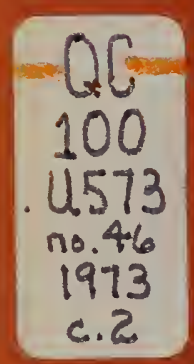

U.S. DEPARTMENT OF COMMERCE

National Bureau of

\section{Reactivity of the Hydroxyl Radical in Aqueous Solutions}


The National Bureau of Standards ${ }^{1}$ was established by an act of Congress March 3, 1901. The Bureau's overall goal is to strengthen and advance the Nation's science and technology and facilitate their effective application for public benefit. To this end, the Bureau conducts research and provides: (1) a basis for the Nation's physical measurement system, (2) scientific and technological services for industry and government, (3) a technical basis for equity in trade. and (4) technical services to promote public safety. The Bureau consists of the Institute for Basic Standards, the Institute for Materials Research, the Institute for Applied Technology, the Institute for Computer Sciences and Technology, and the Office for Information Programs.

THE INSTITUTE FOR BASIC STANDARDS provides the central basis within the United States of a complete and consistent system of physical measurement; coordinates that system with measurement systems of other nations; and furnishes essential services leading to accurate and uniform physical measurements throughout the Nation's scientific community, industry. and commerce. The Institute consists of a Center for Radiation Research, an Office of Measurement Services and the following divisions:

Applied Mathematics - Electricity - Mechanics - Heat - Optical Physics - Nuclear Sciences - - Applied Radiation 2 - Quantum Electronics ${ }^{3}$ - Electromagnetics ${ }^{3}$ — Time and Frequency ${ }^{3}$ - Laboratory Astrophysics ${ }^{3}$ - Cryogenics 3.

THE INSTITUTE FOR MATERIALS RESEARCH conducts materials research leading to improved methods of measurement, standards, and data on the properties of well-characterized materials needed by industry, commerce, educational institutions, and Government; provides advisory and research services to other Government agencies; and develops, produces, and distributes standard reference materials. The Institute consists of the Office of Standard Reference Materials and the following divisions:

Analytical Chemistry - Polymers - Metallurgy - Inorganic Materials - Reactor

Radiation - Physical Chemistry.

THE INSTITUTE FOR APPLIED TECHNOLOGY provides technical services to promote the use of available technology and to facilitate technological innovation in industry and Government; cooperates with public and private organizations leading to the development of technological standards (including mandatory safety standards), codes and methods of test; and provides technical advice and services to Government agencies upon request. The Institute consists of a Center for Bulding Technology and the following divisions and offices:

Engineering and Product Standards - Weights and Measures - Invention and Innovation - Product Evaluation Technology - Electronic Technology - Technical Analysis - Measurement Engineering - Structures, Materials, and Life Safety * Building

Environment * - Technical Evaluation and Application" - Fire Technology.

THE INSTITUTE FOR COMPUTER SCIENCES AND TECHNOLOGY conducts research and provides technical services designed to aid Government agencies in improving cost effectiveness in the conduct of their programs through the selection, acquisition, and effective utilization of automatic data processing equipment; and serves as the principal focus within the executive branch for the development of Federal standards for automatic data processing equipment, techniques, and computer languages. The Center consists of the following offices and dıvisions:

Information Processing Standards - Computer Information - Computer Services -

Systems Development - Information Processing Technology.

THE OFFICE FOR INFORMATION PROGRAMS promotes optimum dissemination and accessibility of scientific information generated within NBS and other agencies of the Federal Government; promotes the development of the National Standard Reference Data System and a system of information analysis centers dealing with the broader aspects of the National Measurement System; provides appropriate services to ensure that the NBS staff has optimum accessibility to the scientific information of the world. The Office consists of the following organizational units

Office of Standard Reference Data - Office of Technical Information and Publications -

I ibrary - Office of International Relations.

2. Headquarlers and Laboratories a: Gaithersburg. Maryland, unless otherwise noted; mailing address it as ington, D C. 20234.

2 Part of the Center for Radiation Research.

3 Locared at Boulder. Colorado 80302.

- Part of the Cen er for Building Technology. 


\section{Reactivity of the Hydroxyl Radical in Aqueous Solutions}

Leon M. Dorfman

Department of Chemistry

The Ohio State University

Columbus, Ohio 43210

and

Gerald E. Adams

Cancer Research Campaign

Grey Laboratory

Mount Vernon Hospital

Northwood, Middlesex, England

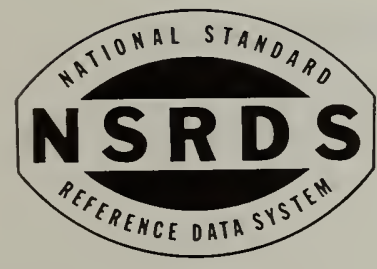

U.S. DEPARTMENT OF COMMERCE, Frederick B. Dent, Secretary NATIONAL BUREAU OF STANDARDS, Richard W. Roberts, Director

Issued June 1973 


\section{Library of Congress Catalog Card Number: 72-600321}

\section{NSRDS-NBS 46}

Nat. Stand. Ref. Data Ser., Nat. Bur. Stand. (U.S.), 4672 pages (June 1973)

CODEN: NSRDAP

(C) 1972 by the Secretary of Commerce on Behalf of the United States Government

For sale by the Superintendent of Documents, U.S. Government Printing Office, Washington, D.C. 20402 (Order by SD Catalog No. C13.48:46) 


\section{Foreword}

The National Standard Reference Data System provides access to the quantitative data of physical science, critically evaluated and compiled for convenience and readily accessible through a variety of distribution channels. The System was established in 1963 by action of the President's Office of Science and Technology and the Federal Council for Science and Technology, and responsibility to administer it was assigned to the National Bureau of Standards.

NSRDS receives advice and planning assistance from a Review Committee of the National Research Council of the National Academy of Sciences-National Academy of Engineering. A number of Advisory Panels, each concerned with a single technical area, meet regularly to examine major portions of the program, assign relative priorities, and identify specific key problems in need of further attention. For selected specific topics, the Advisory Panels sponsor subpanels which make detailed studies of users' needs, the present state of knowledge, and existing data resources as a basis for recommending one or more data compilation activities. This assembly of advisory services contributes greatly to the guidance of NSRDS activities.

The System now includes a complex of data centers and other activities in academic institutions and other laboratories. Components of the NSRDS produce compilations of critically evaluated data, reviews of the state of quantitative knowledge in specialized areas, and computations of useful functions derived from standard reference data. The centers and projects also establish criteria for evaluation and compilation of data and recommend improvements in experimental techniques. They are normally associated with research in the relevant field.

The technical scope of NSRDS is indicated by the categories of projects active or being planned: nuclear properties, atomic and molecular properties, solid state properties, thermodynamic and transport properties, chemical kinetics, and colloid and surface properties.

Reliable data on the properties of matter and materials is a major foundation of scientific and technical progress. Such important activities as basic scientific research, industrial quality control, development of new materials for building and other technologies, measuring and correcting environmental pollution depend on quality reference data. In NSRDS, the Bureau's responsibility to support American science, industry, and commerce is vitally fulfilled. 



\section{Contents}

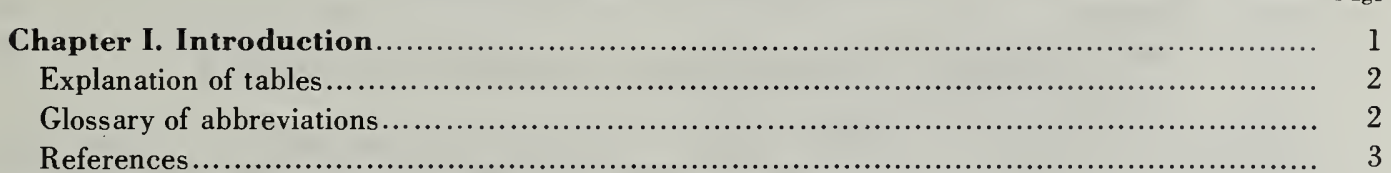

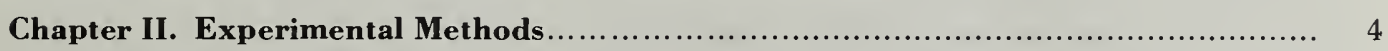

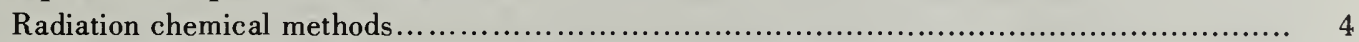

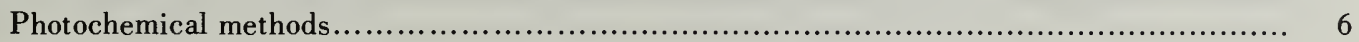

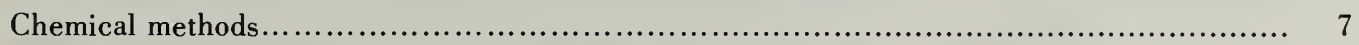

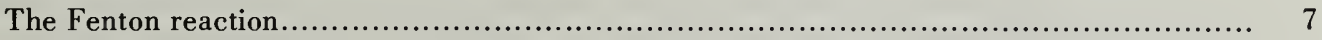

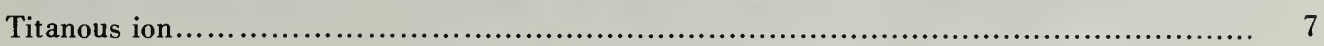

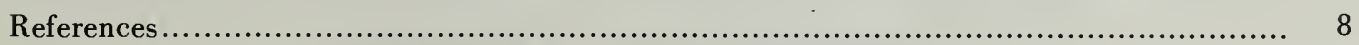

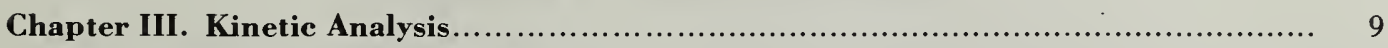

Direct observation of product formation.......................................................... 9

Direct observation of hydroxyl radical disappearance........................................... 10

Competition kinetic measurements............................................................ 10

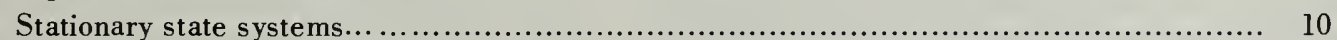

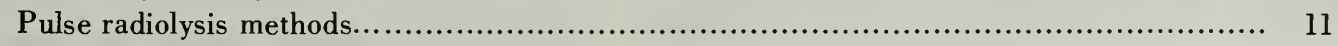

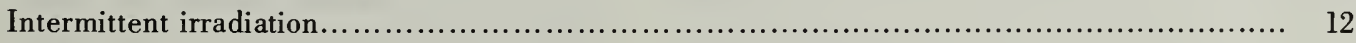

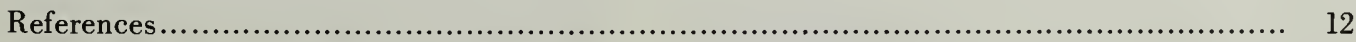

Chapter IV. Physical Properties and Chemical Equilibrium.............................. 13

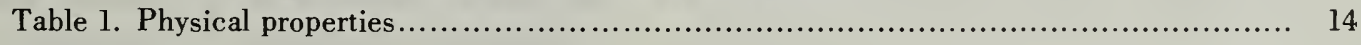

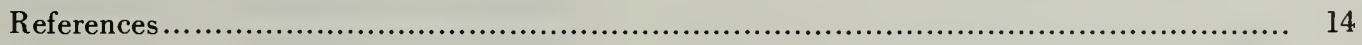

Chapter V. Addition Reactions.............................................................. 15

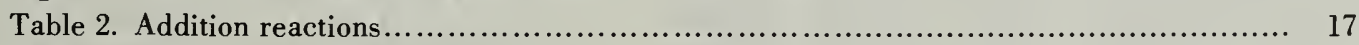

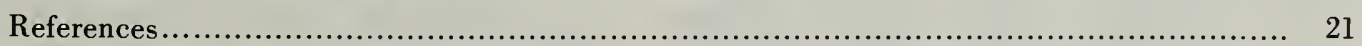

Chapter VI. Hydrogen Abstraction Reactions.............................................. 22

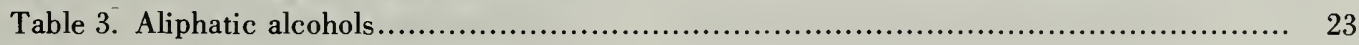

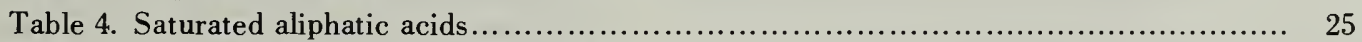

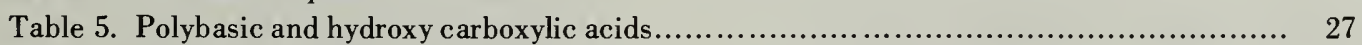

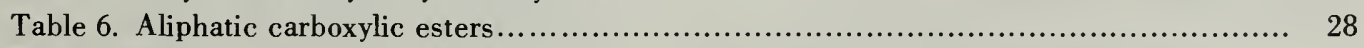

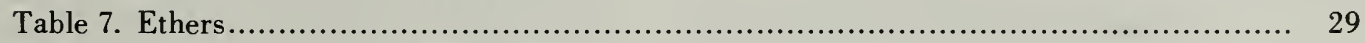

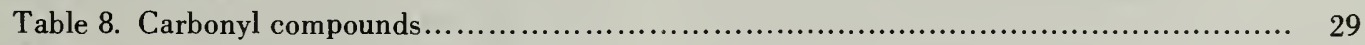

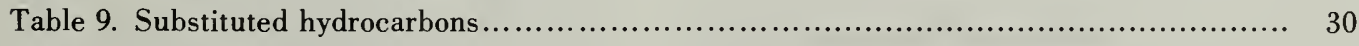

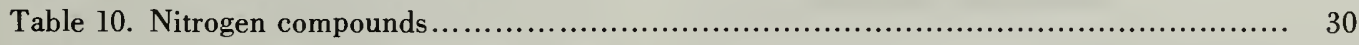

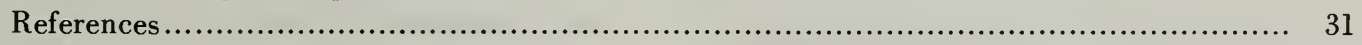

Chapter VII. Inorganic Electron Transfer Reactions................................... 21

Table 11. Inorganic electron transfer reactions................................................... 33

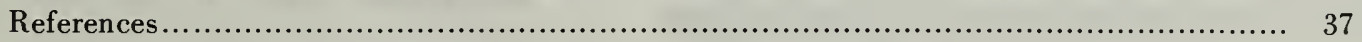

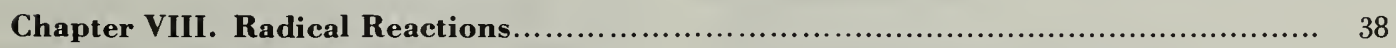

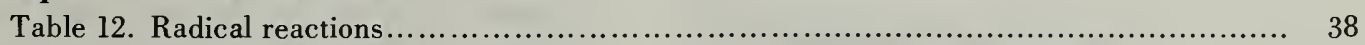

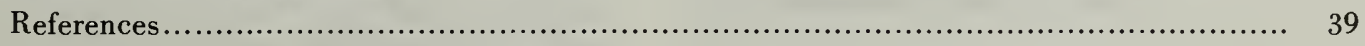

Chapter IX. Reactions of the Oxide Radical Ion...................................... 40

Table 13. Reactions of the oxide radical ion.................................................... 40

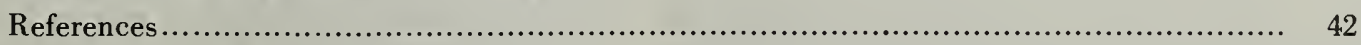


Chapter X. Reactions With Biological Molecules.................................... 43

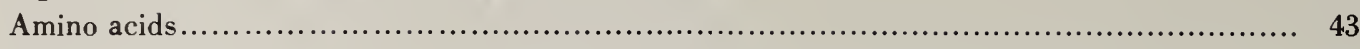

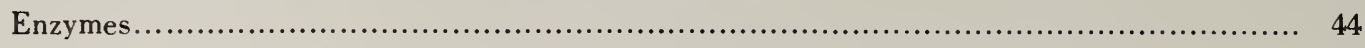

Nucleic acid derivatives................................................................ 45

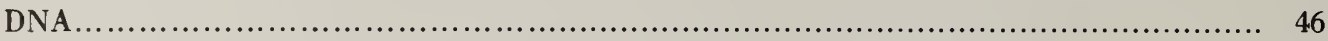

Table 14. Sulfur and selenium compounds................................................ 46

Table 15. Amino acids ............................................................... 47

Table 16. Simple peptides........................................................... 49

Table 17. Enzymes................................................................... 50

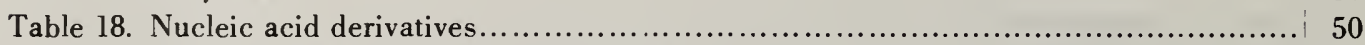

Table 19. Carbohydrates and related compounds ........................................ 53

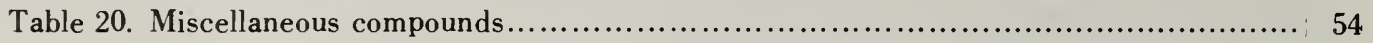

References............................................................................. 56

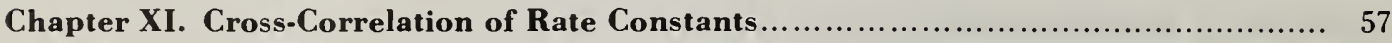

Table 21. Comparison of values from different methods ................................... 58

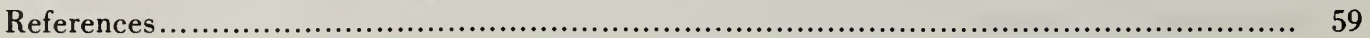




\title{
Reactivity of the Hydroxyl Radical in Aqueous Solutions
}

\author{
Leon M. Dorfman and Gerald E. Adams
}

\begin{abstract}
The reaction rate data of the hydroxyl radical in aqueous solution are compiled and evaluated in this critical review. The values are reported in a series of tables covering addition, hydrogen abstraction, inorganic electron transfer and radical reactions. Rate constants for the hydroxyl radical with biological molecules are included. In addition, the rate constant data for the oxide radical ion are given. Physical properties are listed and the experimental methods employed in $\mathrm{OH}$ radical chemistry are reviewed. An analysis involving rate constant data comparisons is made.
\end{abstract}

Key words: Abstraction reactions; addition reactions; aqueous solution; biological molecules; electron transfer reactions; hydroxyl radical; oxide radical ion; radical reactions; rate constants; reference data.

\section{Chapter I. Introduction}

Water is the most important single solvent in which the physical and chemical processes that can occur are of broad importance in so many areas of the natural sciences. As a result, the rates and equilibria of chemical reactions in aqueous solution have been the subject of countless investigations of almost every conceivable chemical system of substances soluble in water. Among the important chemical reactions occurring in water are those of the free hydroxyl radical, $\mathrm{OH}$, a reactive decomposition product of water which exhibits strong oxidizing properties. Indeed, it is one of the strongest of chemical oxidizing agents.

Hydroxyl radical reactions are of importance in both chemical and biological systems. In chemical systems, such reactions may be fundamental steps in the hydroxylation and oxidation of aquo-organic systems, in the oxidation of inorganic ions and ion complexes, and in the initiation of polymerization. In aqueous solutions which have been exposed to ionizing radiation, the hydroxyl radical is one of the two principal reactive species formed in the decomposition of the water. Subsequent oxidation reactions are the result of its formation. It is, in fact, the application of fast reaction methods in radiation chemistry which has provided the major part of the new information on the reactivity of the hydroxyl radical, to which this monograph is directed.

In radiation biology, since 80 percent of the cell consists of water, reactions of the hydroxyl radical as a reactive transient are important in biological damage. The effects are indirect and evidence has recently been accumulated which shows that a substantial part of this indirect damage to the cells, in many systems, is due to oxidative effects which may be attributable to the hydroxyl radical. Information from such studies, moreover, has a bear- ing on our understanding of molecular processes in biological systems in general.

The chemical reactions of the hydroxyl radical in water may be classified as four different types. These are:

(a) Addition

$$
\mathrm{OH}+\mathrm{C}_{6} \mathrm{H}_{6}=(\mathrm{OH}) \mathrm{C}_{6} \mathrm{H}_{6} .
$$

in which the hydroxyl radical adds to an unsaturated compound, aliphatic or aromatic, to form a free radical product. The addition to aromatic compounds, from which various cyclohexadienyl radicals are formed, is typical;

(b) Hydrogen Abstraction

$$
\mathrm{OH}+\mathrm{CH}_{3} \mathrm{OH}=\cdot \mathrm{CH}_{2} \mathrm{OH}+\mathrm{H}_{2} \mathrm{O}
$$

to form a free radical and water;

\section{(c) Electron Transfer}

$$
\mathrm{OH}+\left[\mathrm{Fe}(\mathrm{CN})_{6}\right]^{4-}=\left[\mathrm{Fe}(\mathrm{CN})_{6}\right]^{3-}+\mathrm{OH}^{-}
$$

to form ions in a higher valence state, or an atom or free radical if a mononegative ion is oxidized, and the hydroxide ion;

\section{(d) Radical Interaction}

$$
\mathrm{OH}+\mathrm{OH}=\mathrm{H}_{2} \mathrm{O}_{2}
$$

in which the hydroxyl radical reacts with another hydroxyl radical, or with an unlike radical, to combine or to disproportionate to form a stable product. 
A subclassification of these four reaction types exists since the hydroxyl radical has more than one form. $\mathrm{OH}$ behaves like a weak acid, ionizing in very strongly basic solution to form $\mathrm{O}^{-}$, a species whose reactivity differs substantially from that of $\mathrm{OH}$.

Many separate reactions of each type have been investigated and the specific reaction rates determined. Precise quantitative information has been developed principally through the application of the pulse radiolysis technique. Since the radiolysis of water, the mechanism of which is fairly completely understood, produces hydroxyl radicals in known yields, the use of this fast reaction method has been most fruitful in determining the chemical reactivity of $\mathrm{OH}$.

The observation of the spectra of cyclohexadienyl radicals by Dorfman and his co-workers [1-3] ${ }^{1}$, and their determination of rate constants for several addition reactions of $\mathrm{OH}$, led to subsequent measurements of such rate constants for a large number of organic compounds. The work of Rabani and Matheson $[4,5]$ on the reactivity of the hydroxyl radical with ferrocyanide ion, provided an example of electron transfer in a reaction which has proved useful as a reference reaction. The generality of such electron transfer reactions of $\mathrm{OH}$ with inorganic anions and complexes was demonstrated by Adams and Boag $[6,7]$ who observed the formation of optically absorbing transients from anions of Group 4-7 of the periodic table. A large part of the work which has provided the information contained in this monograph has evolved from studies of this type.

A critical appraisal and compilation of available data constitutes the substance of this monograph. Any quantitative model for a reacting system rests on a knowledge of the individual rate constants for the elementary reactions of the reactive transient species. Most satisfactory tests of the validity of such models require a knowledge of these individual rate constants. It is our hope that the contents of this critical compilation will prove useful in different areas of research.

\section{Explanation of Tables}

The information contained in these tables represents a critical evaluation as well as a compilation. Accordingly, the tables contain not only the values and the cogent parameters of the system, but also brief notations about the method used in each case and the particular experimental conditions which may be crucial in establishing the validity of the results obtained. In the case of many of the rate constants determined on a relative basis, the values presented in these tables will be found not to coincide with the values suggested by the original authors. Such values have been corrected to bring them into accord with the most reliable values available for the rate constants of reference reactions

' Figures in brackets indicate the literature references at the end of each chapter. References are numbered independently for each chapter. which have been used in the determination of these relative values. The following notation has been used to distinguish the characteristics of the values wherever possible:

*, absolute values - which do not depend upon the value of a rate constant for some reference reaction used in competition studies;

$\dagger$, most reliable values-values of which the accuracy (within the stated experimental uncertainty or lacking such a statement, within $\pm 30 \%$ ) seems least open to question considering such factors as the scatter, or in some cases the paucity of the experimental results or, more commonly, the complexities in interpretation of the data.

The selection has the following basis: Values merit the confidence implied by the designation "most reliable" when they are obtained by methods:

(a) which are as direct as possible,

(b) which involve only few, well-established assumptions about mechanism, and

(c) from which the evaluation of the data follows from a closed analytical solution of the rate equations for such a mechanism, or from a computer analysis of these rate equations. Accordingly it is not surprising that most of the values so designated have been determined absolutely by pulse radiolysis, or in competition kinetics by pulse radiolysis rather than by analysis of stable products. It may be helpful to point out that, conversely, the following negative criteria have, in general, been applied in excluding the $\dagger \cdot$ designation for many of the data whenever:

(a) the system involves a complex mechanism which may not be clearly established, or more particularly,

(b) the relationship between the species monitored and the reaction of the hydroxyl radical is not clearly established, or

(c) the degree of scatter of the results is so great as to raise a question about the meaningfulness of the average, or

(d) the variation of appropriate physical parameters covers too small a range to constitute a satisfactory test of validity of the kinetic analysis, or

(e) insufficient information has been provided to judge whether the criteria for inclusion have been met. Data from the thiocyanate competition method, for example, have not been desig. nated most reliable because of uncertainties about the mechanism; nor have values for the reactions with aromatic compounds obtained by carbon dioxide analysis because of the uncertainty in relating the yield of this stable product to the rate of the elementary reaction in question.

The designation of most reliable values should be viewed as an attempt to provide some guidance to the reader who is not familiar with the details of the methods. It is not bestowed as an accolade. 
Although we may have erred in selecting too few values as "most reliable", it is clear to us that the inclusion of such a designation enhances the value of the compilation.

\section{Glossary of Abbreviations}

The following abbreviations have been used in the tables to conserve space:

\begin{tabular}{|c|c|}
\hline abs. & absorbed \\
\hline addit. & addition \\
\hline & $\begin{array}{l}\text { calculated or calculation } \\
\text { competition or competitive }\end{array}$ \\
\hline comput. & computer \\
\hline conc. & concurrent \\
\hline corr. & correction or corrected \\
\hline $\begin{array}{l}\epsilon \\
\text { ferrocyan. }\end{array}$ & $\begin{array}{l}\text { molar extinction coefficient } \\
\text { ferrocyanide }\end{array}$ \\
\hline form. & formation \\
\hline & $\begin{array}{l}\text { radiation chemical yield (molecules } \\
\text { reacting or forming per } 100 \mathrm{eV} \\
\text { absorbed) }\end{array}$ \\
\hline irrad. & irradiation \\
\hline & $\begin{array}{l}\text { 2-propanol } \\
\text { neutral }\end{array}$ \\
\hline
\end{tabular}

obs.

PNBA

PNDA

prod.

$\mathrm{P}$

$\mathrm{R}$

reac.

rel.

RT

$\mathrm{S}$

scav.

thiocvan.

observed or observation

$p$-nitrobenzoate ion

$p$-nitrosodimethyl aniline product pulse radiolysis reaction relative room temperature steady scavenger or scavenged thiocyanate

\section{Chapter I. References}

[1] Dorfman, L. M., Taub, I. A., Bühler, R. E., J. Chem. Phys. 36, 3051 (1962).

[2] Wander, R., Neta, P., and Dorfman, L. M., J. Phys. Chem. 72, 2946, (1968).

[3] Neta, P., and Dorfman, L. M., Advances in Chemistry Series No. 81, Radiation Chemistry I, 222 (1968). R. F. Gould, Ed.

[4] Rabani, J., and Matheson, M. S., J. Amer. Chem. Soc. 86, 3175 (1964).

[5] Rabani, J., and Matheson, M. S., J. Phys. Chem. 70, 761 (1966).

[6] Adams, G. E., and Boag, J. W., Proc. Chem. Soc., 112 (1964).

[7] Adams, G. E., Boag, J. W., and Michael, B. D., Proc. Chem. Soc., 411 (1964). 


\section{Chapter II. Experimental Methods}

Several different methods of generating hydroxyl radicals in water, or in aqueous solutions, have been used. Among these are: (1) radiation chemical methods in which water is decomposed by ionizing radiation, as, for example, by electrons, (2) photochemical methods in which hydroxyl radicals are formed from water by the absorption of light in the vacuum ultraviolet, or from hydrogen peroxide in solution by the absorption of light in the ultraviolet, and (3) chemical methods in which the hydroxyl radical is formed in a chemical reaction as in Fenton's reaction, or the reaction of titanous ion with hydrogen peroxide.

The determination of the specific reactivity of hydroxyl in its elementary reactions further requires that the method of generation permits the isolation and observation of individual elementary reactions, preferably by fast reaction methods. The pulse radiolysis method [1-5] has proved to be by far the most effective fast reaction technique for the study of hydroxyl radical kinetics and it is from such investigations that the bulk of the data tabulated here have originated.

The brief description of the experimental methods which follows, is in no way intended to be a manual of technique. It is simply a brief summary, intended to provide the general reader with some understanding of the method of generating hydroxyl radicals and of observing their reactions and determining from such observations, the individual rate constants. It is intended to give the reader some appreciation of the complexities which are encountered in arriving at the final results.

\section{Radiation Chemical Methods}

The decomposition of water as a result of the absorption of energy from ionizing radiation passing through it produces some stable products and some reactive intermediates, the identity of which has been well established by investigations extending over three decades [6-8]. The principal reactive intermediates are the hydroxyl radical, which exhibits oxidizing properties and the hydrated electron (along with a smaller yield of hydrogen atom) which exhibits reducing properties. The radiation chemical decomposition of neutral water may be represented as:

$$
\mathrm{H}_{2} \mathrm{O}-\leadsto \rightarrow \mathrm{OH}, e_{\mathrm{aq}}^{-}, \mathrm{H}, \mathrm{H}_{2}, \mathrm{H}_{2} \mathrm{O}_{2}, \mathrm{H}_{3} \mathrm{O}_{\mathrm{aq}}^{+}, \mathrm{OH}_{\mathrm{aq}}^{-}
$$

In addition to the oxidizing species, $\mathrm{OH}$, and the reducing species, $e_{\mathrm{aq}}^{-}$and $\mathrm{H}$, there is a smaller yield of molecular products, hydrogen and hydrogen peroxide. These are thought to be formed, at least in part, in local regions of high concentration of the primary species resulting from the spatially inhomogeneous initial distribution of energy in the system, in regions called spurs and blobs (depending on their size). These have spherical radii which are initially less than $100 \AA$. The hydronium ion is formed in the rapid ion molecule reaction which forms the hydroxyl radical:

$$
\mathrm{H}_{2} \mathrm{O}^{+}+\mathrm{H}_{2} \mathrm{O}=\mathrm{H}_{3} \mathrm{O}^{+}+\mathrm{OH}
$$

This reaction occurs in a time shorter than the dielectric relaxation time and thus, before the $\mathrm{H}_{2} \mathrm{O}^{+}$ is solvated. Hydrated electrons are formed in less than $10^{-11} \mathrm{~s}$ as the secondary electrons in the system approach thermalization. Both $\mathrm{OH}$ and $e_{\mathrm{aq}}^{-}$are thus formed in times shorter than $10^{-11} \mathrm{~s}$. The hydroxide ion, indicated in reaction ( 1 ), is formed by interaction of a hydrated electron with hydroxyl radical in the spurs.

The yields of these transient species are a function of radiation quality and of $\mathrm{pH}$. For neutral solutions and with electrons of energy greater than about $1 \mathrm{MeV}$ the yields [6,9-12] (represented by the symbol $G$ ) are: $G_{\mathrm{OH}}=2.8, G_{e^{-a}}=2.8, G_{\mathrm{H}}=0.55$, $G_{\mathrm{H}_{2}}=0.45, G_{\mathrm{H}_{2} \mathrm{O}_{2}}=0.7, G_{\mathrm{H}_{3} \mathrm{O}^{+}}=2.9$ and $G_{\mathrm{OH}_{-}}=$ 0.1 molecules $/ 100 \mathrm{eV}$. With regard to the study of the kinetics of the hydroxyl radical then, irradiated water may be regarded as essentially a two-radical system of $\mathrm{OH}$ and $e_{\mathrm{aq}}^{-}$, with $\mathrm{H}$ amounting to only 9 percent of the total initial concentration of reactive radicals. It is also possible to convert the hydrated electrons into hydroxyl radicals by the use of nitrous oxide as an electron scavenger. The occurrence of the overall reaction

$$
e_{\mathrm{aq}}^{-}+\mathrm{N}_{2} \mathrm{O}+\mathrm{H}_{2} \mathrm{O}=\mathrm{N}_{2}+\mathrm{OH}+\mathrm{OH}^{-}
$$

the nature of which will be discussed in a subsequent chapter, thus creates very nearly a oneradical system of $\mathrm{OH}$ in water, with the initial concentration ratio $[\mathrm{OH}]_{0} /[\mathrm{H}]_{0} \cong 10$.

It should be pointed out that it is the nature of the process of energy loss by the ionizing radiation that makes the radiolysis of water the most convenient method for generating hydroxyl radicals in aqueous solutions. The energy loss process, resulting in ionization and excitation of the absorber system by electron impact, is one of coulombic interaction of incident electrons with the system electrons and depends roughly on the electron density of the 
components of the system. In dilute solutions of any solute, therefore, it is the water which absorbs almost all the energy, leaving the solute molecules relatively unaffected. This is in contrast to the partition of incident energy in the photolysis of dilute solutions, where the high energy photons necessary for the decomposition of water or hydrogen peroxide will also be absorbed quite strongly by most solutes of interest even at low concentration.

It should also be understood that the energy of the incident electrons is not a physical parameter fundamental to the investigations since a continuous electron energy degradation spectrum exists in the system.

Although the initial spatial distribution of the reactive transients in irradiated water is nonhomogeneous and has itself been the subject of direct investigation [13] on a time scale of $10^{-11} \mathrm{~s}$, this heterogeneity is short-lived. The spurs have a lifetime on the order of $10^{-9}$ to $10^{-8} \mathrm{~s}$, after which the distribution of the reactive transients becomes homogeneous by diffusion. Most kinetic investigations of hydroxyl radical reactivity have been carried out on a time scale greater than $10^{-8} \mathrm{~s}$. The hydroxyl radicals generated in this way are in the ground electronic state and, presumably, in the ground vibrational state since collisional de-excitation in condensed phase would be very rapid.

Since the radiolysis of water provides such a convenient means of producing hydroxyl radicals, the development of the pulse radiolysis technique furnished an ideal fast reaction method for the study of their reactivity. In this method, the radiation is delivered to the solution in a single pulse, the duration of which may range from $10^{-11}$ to $10^{-6} \mathrm{~s}$. Most investigations of hydroxyl radical reactivity have utilized electron pulses ranging from $50 \mathrm{~ns}$ to $1 \mu \mathrm{s}$ in duration.

The source of the electron pulse in such studies may be any one of a number of different types of electron accelerators. Microwave linear accelerators, with energies ranging from about 2 to $30 \mathrm{MeV}$, are used most extensively in such applications. Van de Graff accelerators, modified to store charge and deliver a single, high current electron pulse, usually at 2 or $3 \mathrm{MeV}$, have been used in several laboratories. The Febetron ${ }^{2}$, an impulse machine utilizing a capacitor bank with a Marx surge circuit to deliver a pulse of fixed length at $2 \mathrm{MeV}$, is a convenient source for pulse radiolysis. $\mathrm{X}$ rays have been used infrequently because of the conversion loss and have not been applied in any of the work on hydroxyl radicals. Detailed characteristics of most of the sources used have been presented in a recent book [4] on this subject.

The characteristics of the electron pulse, which are of importance in fast reaction studies are its duration and time-profile and its amplitude. Pulse

- Certain commercial products and instruments are identified in this work in order to specify adequately the experimental procedure. In no case does such identification imply recommendation or endorsement by the National Bureau of Standards. lengths ranging from $\mathrm{l} n \mathrm{~ns}$ to $\mathrm{l} \mu \mathrm{s}$ or longer are readily available; pulse lengths of less than $20 \mathrm{ps,}$ from the fine structure of a microwave linac pulse, have been used in a special application [14]. The pulses with a duration greater than a few nanoseconds are fairly well represented as a square waveform. Thus, the Van de Graaff at Argonne National Laboratory, with which pulses as short as $1 \mathrm{~ns}$ have been used, has a pulse with rise time and decay time of less than $0.5 \mathrm{~ns}$. The microwave linac at the Ohio State University, with which pulses generally longer than $10 \mathrm{~ns}$ have been used, has rise and decay times of $5 \mathrm{~ns}$. It is an important convenience in the interpretation of kinetic data that the time-profile of the pulse approximates to a square waveparticularly that the falling edge is represented by a step function.

The pulse current must be high enough so that a single pulse delivers sufficient power to the system in order to produce an observable concentration of the transient species of interest. With the shortest electron pulses, currents in the range of several amperes to several tens of amperes have been used; with the longer pulses, currents are generally of the order of $0.1 \mathrm{~A}$ to almost $1 \mathrm{~A}$. In any event, the magnitude of the product of current, duration, and voltage of the pulse is such that, in most applications, a single pulse will deliver in the range of 0.02 to $5 \mathrm{~J}$. With most systems, this is a sufficient power level to produce an "instantaneous" concentration of transient species in the range of $10^{-7} M$ to almost $10^{-4} M$. Such a concentration is readily detectable by a variety of methods.

The solution into which this energy perturbation is injected is generally contained in a quartz cell of rectangular or cyclindrical design with a volume generally larger than a few $\mathrm{ml}$, and, perhaps, up to several tens of $\mathrm{ml}$, depending upon the electron beam energy. The power level is insufficient, therefore, to produce any significant temperature rise in the system.

The reaction of interest may be observed by monitoring one of the properties of either the reactive intermediate or of a product formed directly in the elementary reaction, over an appropriate period of time following the electron pulse. Properties which have been used are: optical absorption, optical emission if this occurs, electron spin resonance absorption if the requirement of time resolution permits, and electrical conductivity if the species is charged. Optical absorption is the most versatile of these methods and has proved to be by far the most extensively used. In this case, the optical absorption of a monitoring light beam passing through the reaction cell is measured by fast spectrophotoelectric recording at an appropriate wavelength, starting at, or before, the time of the pulse and extending after it for several half-times of the observed reaction. A typical rate curve for the formation of a product in a hydroxyl radical reaction is shown in figure 1 . The identity of the absorbing species may, in some cases, be known from previous work in which the spectrum 


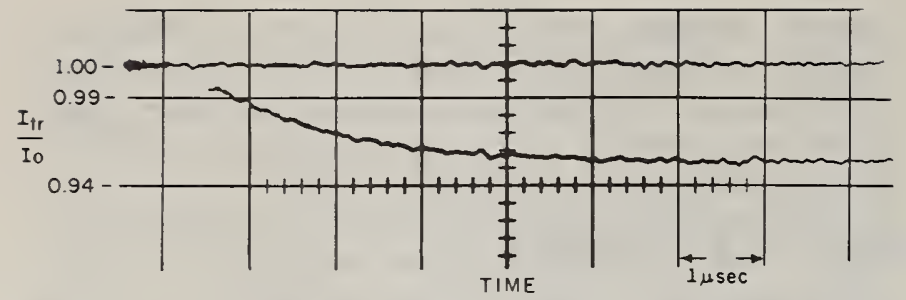

FIGURE 1. Rate curve for the reaction of the oxide radical ion, $\mathrm{O}^{-}$, with ethanol obtained by observing the formation of the $\cdot \mathrm{C}_{2} \mathrm{H}_{4} \mathrm{O}^{-}$radical ion at $360 \mathrm{~nm}$ following a $300 . \mathrm{ns}$ electron pulse in an aqueous solution at $\mathrm{pH} 13.92$ containing $4.3 \times 10^{-4} \mathrm{M}$ ethanol.

The fraction of the light transmitted is shown as a function of time at a sweep speed of $1 \mu \mathrm{s} / \mathrm{cm}$ on the oscilloscope. Data taken from reference [7], chapter IX.

has already been assigned; in others, it may be the subject of some speculation in the event the identity is based on the chemical behavior of the system.

Rate constants for reactions of the hydroxyl radical, with the exception of the combination reaction and the reaction with molecular hydrogen, have not been determined by observing $\mathrm{OH}$ directly. An optical absorption in the far uv $[15,16 a]$ thought to be that of the hydroxyl radical in water, is too weak, and in a spectral region too readily obscured by most solutes to be used for this purpose. Instead, the rate curves for product formation have been used.

In many cases, as will be explained, rate constants have been determined by competition, in which the relative concentration, rather than the rate, of a product formed is determined. Such competition methods may utilize a steady radiation source such as a $\mathrm{Co}^{60} \gamma$-ray source rather than a pulsed electron source and will, in that case, involve the relative concentration of a stable product rather than that of an intermediate.

Another radiation chemical method which has been used effectively for the determination of rate constants of two important reactions of $\mathrm{OH}$, is the equivalent of the rotating sector method. A pulsed Van de Graaff accelerator, in which the pulse duration and period could be varied, was used.

\section{Photochemical Methods}

Water vapor absorbs strongly in the vacuum ultraviolet region of the spectrum, the continuum extending from about 145 to $200 \mathrm{~nm}$. This absorption was, at first, thought to result in the photodissociation reaction:

$$
\mathrm{H}_{2} \mathrm{O} \longrightarrow\left[\mathrm{H}_{2} \mathrm{O}^{*}\right] \longrightarrow \mathrm{H}_{2}+\mathrm{O} .
$$

However, it was argued, on energetic grounds, that the dissociation is not possible for wavelengths longer than about $180 \mathrm{~nm}$ and that the primary dissociation step is:

$$
\mathrm{H}_{2} \mathrm{O} \longrightarrow\left[\mathrm{H}_{2} \mathrm{O}^{*}\right] \longrightarrow \mathrm{H}+\mathrm{OH} .
$$

The absorption spectrum in liquid water is dis placed slightly to longer wavelength. The first indica- tion that reaction 5 also occurs in the liquid phase, was the demonstration that ferric ion is formed in the flash photolysis of aqueous solution of ferrous ion with light of wavelength below $200 \mathrm{~nm}$ [16b]. In an extension of this work [17], the observation that $\mathrm{H}_{2} \mathrm{O}_{2}$ is a major product in the flash photolysis of deaerated water, provided fairly reliable confirmation that this reaction takes place. There is no experimental evidence that solutes, certainly at concentrations less than $1 M$, interact with the primary excited state of water. Although liquid water does not absorb above $200 \mathrm{~nm}$, some mercury photosensitized decomposition has been observed in aqueous solution, although the quantum yields are rather low [18].

It was reported [19] that hydroxyl radicals are formed by the photodecomposition of hydrogen peroxide with light of wavelength $253.7 \mathrm{~nm}$ :

$$
\mathrm{H}_{2} \mathrm{O}_{2} \longrightarrow \mathrm{OH}+\mathrm{OH} \text {. }
$$

Under some conditions the quantum yields for $\mathrm{H}_{2} \mathrm{O}_{2}$ removal can be extremely high, suggesting the occurrence of chain processes, although, at high light intensities, the chain length decreases. A study of the kinetics of $\mathrm{H}_{2} \mathrm{O}_{2}$ photodecomposition indicated, initially, a primary quantum yield of unity [20]. However, a subsequent investigation [21] of the photo-oxidation of formic acid in solution containing $\mathrm{H}_{2} \mathrm{O}_{2}$ showed that the true quantum yield is 0.5 . The kinetic behavior of the decomposition product is identical to that of the oxidizing species formed in the $\gamma$-radiolysis of water [22] and there is now little doubt that it is the free hydroxyl radical.

The fast-flow technique has been used in an ESR study [23] of the structure of radicals formed by reaction of $\mathrm{OH}$ produced by $\mathrm{H}_{2} \mathrm{O}_{2}$ photolysis. In this technique, which, in some respects, is similar to that used in the fast flow ESR studies with the $\mathrm{Ti}^{3+} / \mathrm{H}_{2} \mathrm{O}_{2}$ reagent described below, $\mathrm{H}_{2} \mathrm{O}_{2}$ solution is photolyzed just before it is passed through the cavity of the ESR spectrometer. Under appropriate conditions, radicals formed by reaction of $\mathrm{OH}$ with a second solute are sufficiently long-lived to permit their ESR spectra to be recorded. As with the other flow experiments, the strength of this technique lies in its suitability for studying the structures of radicals formed by reaction of $\mathrm{OH}$.

Although attempts have been made to use $\mathrm{H}_{2} \mathrm{O}_{2}$ photolysis as a source of $\mathrm{OH}$ radicals for kinetic studies [24, 25], its usefulness is restricted to those few systems where the absorption of the solute at this wavelength is low relative to that of $\mathrm{H}_{2} \mathrm{O}_{2}$.

It has been shown [26] that solutions of ferric ion can initiate vinyl polymerization when irradiated with light of wavelength $365 \mathrm{~nm}$ and oxidize aromatic compounds, including benzene itself [27], to the corresponding phenols. The evidence is strong that the primary photochemical reaction involves an internal electron transfer reaction in a ferric ion complex which leads to ejection of the hydroxyl radical from the solvation shell: 


$$
\mathrm{Fe} \mathrm{OH}^{2+} \rightarrow \mathrm{Fe}^{2+}+\mathrm{OH}
$$

In the case of benzene, the primary quantum efficiency for light of wavelength $313 \mathrm{~nm}$ is 0.13 [27]. There are no reports of this system being used for determining any $\mathrm{OH}$ reactivities.

\section{Chemical Methods}

\section{The Fenton Reaction}

In 1894, Fenton [28] reported that a variety of $\alpha$-hydroxy acids could be oxidized by mixtures of hydrogen peroxide and ferrous salt. Subsequently, it was shown that polyhydric alcohols, sugars, amino compounds, and phenols were similarly oxidized while, at higher temperatures, some simple aliphatic alcohols also reacted. The reactions appeared to be specific to ferrous ion and were dependent upon $\mathrm{pH}$.

In the thirties, the classic work of Haber and Weiss, continued later by Weiss, led to the postulation of the hydroxyl radical as an intermediate in the Fenton reaction [29]. This did much to clarify the mechanisms of the many oxidation processes initiated by this reagent.

To explain the observation that ferrous ion was a much better catalyst than the ferric ion in the dehydrogenation of various substrates by hydrogen peroxide, it was proposed that the initial step is the reaction:

$$
\mathrm{Fe}^{2+}+\mathrm{H}_{2} \mathrm{O}_{2} \rightarrow \mathrm{Fe}^{3+}+\mathrm{OH}+\mathrm{OH}^{-} .
$$

Adequate confirmation of the $\mathrm{OH}$ radical as an intermediate, obtained first from an investigation of the chain polymerization of olefins [30] was provided by evidence from a variety of other systems [31-34].

The mechanism of oxidation of organic substrates by the Fenton reagent can be complex. An initial examination of the kinetics of oxidation of a range of compounds $\lceil 33,34\rceil$ appeared to indicate that the reactions could be classified into "chain" and "nonchain" processes. It was proposed that $\mathrm{OH}$ radicals formed in acid solution by reaction (8) react with an oxidizable substrate $\mathrm{RH}$, by hydrogen abstraction to form the radical $\mathrm{R} \cdot$. Since $\mathrm{H}_{2} \mathrm{O}_{2}$ is present this radical may react in a chain propagation step to regenerate $\mathrm{OH}$ :

$$
\mathrm{R} \cdot+\mathrm{H}_{2} \mathrm{O}_{2} \rightarrow \mathrm{ROH}+\mathrm{OH} \text {. }
$$

In such cases, low concentrations of ferrous ions could initiate the chain oxidation of an excess of organic solute. If, however, reaction (9) were slow, chain termination could occur by radical-radical reaction by oxidation by Fe III. Since ferrous ion can compete with the substrate for $\mathrm{OH}$, it was proposed that kinetic analysis of the data should yield the rate constant ratio for these two reactions. A large number of relative rate constants were obtained by this method, although it is now known that the mechanisms proposed are incomplete. No account was taken of either the reaction of the organic radical with oxygen or the formation of $\mathrm{HO}_{2}$ in the chain propagation step:

$$
\mathrm{OH}+\mathrm{H}_{2} \mathrm{O}_{2} \rightarrow \mathrm{HO}_{2}+\mathrm{H}_{2} \mathrm{O} \text {. }
$$

The overall reaction mechanism is sensitive, therefore, to the relative concentrations of the various solutes. Nevertheless, the kinetic data are interesting from the historical viewpoint in that they represent the first systematic study of $\mathrm{OH}$ reactivity generally.

Although the Fenton reaction has been used in more recent years for a study of some $\mathrm{OH}$ rate constants [25] the complexities of the oxidation mechanisms seriously limit its reliability as a general kinetic method. As is the case with the titanium/ $\mathrm{H}_{2} \mathrm{O}_{2}$ system described below, the usefulness of the Fenton reaction lies more in its application in fastflow/ESR techniques where the emphasis is on the structure of the radicals formed by reactions of $\mathrm{OH}$ rather than on the kinetics of the processes.

\section{Titanous Ion}

Titanous ion, $\mathrm{Ti}^{3+}$, reacts with $\mathrm{H}_{2} \mathrm{O}_{2}$ in a process analagous to the Fenton reaction, although it has been reported that the reaction is faster [35].

$$
\mathrm{Ti}^{3+}+\mathrm{H}_{2} \mathrm{O}_{2} \rightarrow \mathrm{Ti}^{4+}+\mathrm{OH}+\mathrm{OH}^{-} .
$$

A convenient and fruitful method of studying reactions of the $\mathrm{OH}$ radical generated by this reaction has been used $[36,37]$ in which the reactants, titanous ion, $\mathrm{H}_{2} \mathrm{O}_{2}$, and an organic substrate, $\mathrm{RH}$, are mixed in a rapid-flow apparatus. The combined solution is then passed through the cavity of an electron spin resonance spectrometer a short time after mixing and the ESR spectra of the transient free radicals formed by reaction of $\mathrm{OH}$ with the substrate are recorded.

The mechanism of the titanous ion $/ \mathrm{H}_{2} \mathrm{O}_{2}$ reaction is undoubtedly complex. The $\mathrm{OH}$ radical produced in (11) reacts with both $\mathrm{Ti}^{3+}$ and $\mathrm{H}_{2} \mathrm{O}_{2}$ forming, respectively, $\mathrm{Ti}^{4+}$ and $\mathrm{HO}_{2}$ radicals. The relative efficiency with which $\mathrm{OH}$ can react with an added substrate then depends on the relative solute concentrations. However, further complications arise from the existence of complexes between $\mathrm{H}_{2} \mathrm{O}_{2}$ and the $\mathrm{Ti}^{4+}$ ions formed in the reaction. In the ESR spectrum observed after mixing $\mathrm{Ti}^{3+}$ and $\mathrm{H}_{2} \mathrm{O}_{2}$, two singlet lines are observed which have been attributed to separate species in view of the different time constants for the decay [38,39]. There is little doubt that the singlets are due to complexes of titanium ions and oxyradicals $[40,41]$ and recent evidence [42] indicates that the radical involved in both complexes is $\mathrm{HO}_{2}$.

It has been suggested [40] that the reactive agents in the oxidation of organic substrates are complexes containing titanium ions and $\mathrm{OH}$ radicals and not free $\mathrm{OH}$ and that they are responsible for 
the singlet spectra. Double mixing experiments have shown. however. that this is not so 1431.

When $\mathrm{Ti}^{3+}$ and $\mathrm{H}_{2} \mathrm{O}_{2}$ are brought together a short time before an organic reactant is added, both singlets are still observed. They are not quenched and are certainly due to relatively unreactive species. As would be expected, unless an oxidizable organic substrate is available for reaction immediately the $\mathrm{OH}$ radical is formed, $\mathrm{OH}$ will react with other species in the system. However, there seems little doubt that, despite the complexity of the reaction when such a compound is available at the time of mixing, the reacting species is the free, uncomplexed hydroxyl radical. This is confirmed further by the considerable data concerning the nature of the radicals formed from various organic substrates. Where comparisons are possible, agreement with pulse radiolysis data on radical assignments are good. Examples of reactions studied by the flow method include addition of $\mathrm{OH}$ to aromatic [44] and various unsaturated aliphatic compounds $[45,46]$.

The strength of the fast flow/ESR method lies in the facility for determining the structure of the radicals produced by reaction of $\mathrm{OH}$. However, the limitations imposed by the time resolution available with the method and the complexities of the mechanisms involved, make it less suitable for the quantitative measurement of the kinetics of $\mathrm{OH}$ reactions.

\section{Chapter II. References}

[1] Dorfman, L. M., and Matheson, M. S., Progress in Radiation Kinetics, Vol. III, 237 (1965).

[2] Keene, J. P., J. Sci. Instr. 41, 493 (1964).

[3] Boag, J. W., Actions Chimiques et Biologiques des Radiations, Chap. I, Series VI, M. Haissinsky, ed. (Masson et Cie, Paris, 1963).

[4] Matheson, M. S., and Dorfman, L. M., Pulse Radiolysis (M.I.T. Press, Cambridge, Mass., 1969).

[5] Dorfman, L. M., Science 141, 493 (1963).

[6] Allen, A. O., The Radiation Chemistry of W ater and Aqueous Solutions (D. Van Nostrand Co. Inc., New York, 1961).

[7] Hart, E. J., and Anbar, M., The Hydrated Electron (John T. Wiley, New York, N.Y., 1970).

[8] Mozumder, A., and Magee, J. L., Radiation Res. 28. 203 (1966).

[9] Allan, J. T., and Scholes, G., Nature 187, 218 (1960).

[10] Rabani, J., Mulac, W. A., and Matheson, M. S., J. Phys. Chem. 69,53 (1965).

[11] Rabani, J., and Stein, G., J. Chem. Phys. 37, 1865 (1962).

[12] Schmidt, K. H., and Ander, S. M., J. Phys. Chem. 73, 2846 (1969).

[13] Bronskill, M. J., Wolff, R. K., and Hunt, J. W., J. Chem. Phys. 53, 4201 (1970).
[14] Bronskill, M. J., and Hunt, J. W., J. Phys. Chem. 72, 3762 (1968).

[15] Thomas, J. K., Rabani, J., Matheson, M. S., Hart, E. J., and Gordon, S., J. Phys. Chem. 70, 2409 (1966).

[16a] Pagsberg, P., Christensen, H., Rabani, J., Nillson, G. Fenger, J., and Nielsen, S. O., J. Phys. Chem. 73, 1029 (1969).

[16b] Baxendale, J. H., and Mansell, A. L., Nature 190, 622 (1961).

[17] Baxendale, J. H., Radiation Res. 17, 312 (1962).

[18] Melville, H. W., Proc. Roy. Soc. A, 15 7, 621 (1936).

[19] Milas, N. A., Kurz, P. F., and Anslow, W. P., J. Amer. Chem. Soc. 59, 343 (1937).

[20] Dainton, F. S., and Rowbottom, J., Trans. Faraday Soc. 49, 1160 (1953).

[21] Weeks, J. L., and Matheson, M. S., J. Amer. Chem Soc. 78, 1273 (1956)

[22] Hochanadel, C. J., Radiation Res. 17, 286 (1962).

[23] Livingston, R., and Zeldes, H., J. Chem. Phys. 44, 1245 (1966).

[24] Berces, T., and Trotman-Dickenson, A. F., J. Chem. Soc. 4281 (1961).

[25] Kralic, I., in The Chemistry of Ionization and Excitation, eds. G. R. A. Johnson and G. Scholes (Taylor and Francis Ltd., London, p. 303, 1967).

[26] Uri, N., Chem. Rev. 50, 413 (1952).

[27] Baxendale, J. H., and Magee, J., Trans. Faraday Soc. 51 , 205 (1955).

[28] Fenton, H. J. H., Chem. Soc. (London) 65, 899 (1894).

[29] Haber, F., and Weiss, J. J., Proc. Roy. Soc. A147, 332 (1934).

[30] Baxendale, J. H., Evans, M. G., and Park, G. S., Trans. Faraday Soc. 42, 155 (1946).

[31a] Koltoff, I. M., and Medalia, I. A., J. Amer. Chem. Soc. 71, 3777 (1949).

[31b] Koltoff, I. M., and Medalia, I. A., J. Amer. Chem. Soc. 71, 3784 (1949).

[32] Barb, W. G., Baxendale, J. H., George, P., and Hargrave, K. R., Trans. Faraday Soc. 47, 462 (1951).

[33] Merz, J. H., and Waters, W. A., J. Chem. Soc. S15 (1949).

[34] Merz, J. H., and Waters, W. A., Disc. Faraday Soc. 2, 179 (1947).

[35] Cahill, A. E., and Taube, H. J. Amer. Chem. Soc. 74, 2312 (1952).

[36] Dixon, W. T., and Norman, R. O. C., Nature 196, 891 (1962).

[37] Dixon, W. T., and Norman, R. O. C., J. Chem. Soc. 3119 (1963).

[38] Piette, L. H., Bulow, G., and Loeffler, K., Amer. Chem. Div. Petrol Chem. 09-019 (1964)

[39] Sicilio, F., Florin, R. E., and Wall, L. A., J. Phys. Chem. 70, 47 (1966)

[40] Chiang, Y. S., Craddock, J., Mickewich, D., and Turkevich, J., J. Phys. Chem. 70, 3509 (1966).

[41] Fischer, H., Ber. Bunsenges. Phys. Chem. 71, 685 (1967).

[42] Czapski, G., Levanon, H., and Samuni, A., U.S. Atom. Energy Comm. Report No. NYO-3753-9 (1969).

[43] Jefcoate, C. R. E., and Norman, R. O. C., J. Chem. Soc. (B), 48 (1968).

[44] Lindsay-Smith, J. R., and Norman, R. O. C., J. Chem. Soc. 2897 (1963).

[45] Smith, P., and Wood, P. B., Can. J. Chem. 45, 649 (1967).

[46] Dixon, W. T., Norman, R. O. C., and Buley, A. L., J. Chem. Soc. 3625 (1964). 


\section{Chapter III. Kinetic Analysis}

The rate constants in this compilation have been determined by one or another of the following methods, for which the kinetic analysis will be indicated and some of the requirements and pitfalls mentioned. Three of these methods lead to absolute values for the rate constant, while a fourth, very commonly used, leads to relative values in which only the ratio of the rate constant to that of a competing reference reaction is known.

\section{Direct Observation of Product Formation}

Direct observation of the rate curve for the formation of a product is feasible if the product, $\mathrm{P}$, has a sufficiently strong and accessible optical absorption,

$$
\mathrm{OH}+\mathrm{X}=\mathrm{P} \text {. }
$$

$\mathrm{P}$ may be an adduct free radical, where $\mathrm{X}$ represents a stable molecule or ion, a free radical formed by abstraction of hydrogen, or a radical or ion-product of the oxidation of an ion. If no concurrent reaction of hydroxyl radical such as

$$
\mathrm{OH}+\mathrm{OH}=\mathrm{H}_{2} \mathrm{O}_{2}
$$

is competitive with reaction ( 1 ), a condition that will obtain if the ratio $k_{1}[\mathrm{X}]_{0} / k_{2}[\mathrm{OH}]_{0}$ is sufficiently large, say, greater than 50 , the rate equation for product formation is, simply,

$$
\frac{d[\mathrm{P}]}{d t}=k_{1}[\mathrm{OH}][\mathrm{X}] \text {, }
$$

which reduces, for the condition $[\mathrm{X}]_{0} \gg[\mathrm{OH}]$ to

$$
\frac{d[\mathrm{P}]}{d t}=k_{1}^{\prime}[\mathrm{OH}]
$$

Since the formation of $\mathrm{P}$ and the disappearance of $\mathrm{OH}$ are complementary, the integrated form of this equation, in terms of the optical density, $D_{t}$, of $\mathrm{P}$ at any time, is:

$$
\log \left(D_{x}-D_{t}\right)-\log D_{x}=-0.4343 k_{1}^{\prime} t .
$$

$k_{1}^{\prime}$, the first order rate constant, may then be obtained from the slope of a plot of $\log \left(D_{x}-D_{t}\right)$ versus time, which should be linear. The absolute value for $k_{1}$, the bimolecular rate constant, is then obtained from

$$
k_{1}=k_{1}^{\prime} /[\mathrm{X}]_{0}
$$

In this application, $\mathrm{P}$ must be the only species absorbing at $\lambda_{1}$, the monitoring wavelength, whose concentration changes sensibly during the observation. It is generally not satisfactory, because of the insensitivity of log plots, to rely on a linear plot at only a single concentration of $\mathrm{X}$, but rather more desirable to demonstrate constancy of $k_{1}$, with variation of $[\mathrm{X}]_{0}$ over a reasonable range. If several products are formed concurrently from $\mathrm{OH}$ and $\mathrm{X}$ in reaction (1), $k_{1}$ will be equal to the sum of the rate constants for the individual reactions.

If the rate of reaction (2) is not negligible relative to that of (1), some deviation from linearity will be observed and the occurrence of (2) must be taken into account in the treatment of the data. This can be done quite readily by analog or digital computer calculation since the value for $k_{2}$, as will be seen, is known absolutely. In some cases the reaction of $e_{\mathrm{aq}}^{-}$and of $\mathrm{H}$ will not interfere in the foregoing direct determination of $k_{1}$. In others where one or other may result in the formation with a rate constant differing from $k_{1}^{\prime}$ of a product also absorbing at $\lambda_{1}$, it is necessary to convert $e_{\mathrm{aq}}^{-}$into $\mathrm{OH}$ by means of reaction (3) chapter II, and to take into account the reactivity of $\mathrm{H}$, the concentration of which then amounts to only 10 percent of that of $\mathrm{OH}$.

An experimental condition which has occasionally been overlooked in such rate constant determinations and which can result in small, but significant errors, is the nonuniformity of the radiation flux throughout the cell volume. A variation of the initial concentration of reacting species along the path of the analyzing light has no effect $[1,2]$ upon rate constants for first order reactions and only a small effect in the case of second order reactions. Variation across the light path in the direction of the electron beam, if these are at right angles, has a small effect on first order constants and may have a significant effect upon second order constants, as has been indicated with numerical examples $[1,2]$.

A considerable number of absolute rate constants for reactions such as addition to aromatic molecules, electron transfer from anions, and a special case of hydrogen abstraction, have been determined by such observation of product formation in pulse radiolysis. Included are some reactions which may be used as reference reactions in competition methods. With proper attention to the experimental conditions and care in analysis of the data, absolute rate constants have been obtained with an uncertainty as low as \pm 10 percent in the accuracy, which represents very nearly the best attainable. 


\section{Direct Observation of the Hydroxyl Radical Disappearance}

This method, which is, in principle, the most desirable one, has proved feasible [3-5] for only two reactions, the recombination, reaction (2), and the reaction with molecular hydrogen. As will be seen in chapter IV, a weak optical absorption at wavelengths below $280 \mathrm{~nm}$, seen in irradiated water under appropriate conditions, is thought to be that of the hydroxyl radical. By monitoring this absorption in the presence of a sufficient concentration of hydrogen, an approximate value for the rate constant of the reaction

$$
\mathrm{OH}+\mathrm{H}_{2}=\mathrm{H}_{2} \mathrm{O}+\mathrm{H}
$$

known more accurately from other methods, was determined. In this case for the condition $\left[\mathrm{H}_{2}\right]_{0} \gg$ $[\mathrm{OH}]_{0}$, the integrated form of the differential rate equation, in terms of the optical density of $\mathrm{OH}$, is

$$
\log D_{t}-\log D_{0}=-0.4343 k_{7}^{\prime} t \text {. }
$$

$k_{7}$ may then be obtained absolutely from the slope of the straight line resulting from a plot of $\log D_{t}$ versus time, if $\left[\mathrm{H}_{2}\right]_{0}$ is known.

With $\mathrm{N}_{2} \mathrm{O}$ present to convert $e_{\mathrm{aq}}^{-}$to $\mathrm{OH}$, the rate constant for reaction (2) was determined. If (2) were the only reaction occurring, the integrated form of the differential rate expression for the disappearance of $\mathrm{OH}$, in terms of its optical density, would be:

$$
1 / D_{t}-1 / D_{0}=\left(\frac{2 k_{2}}{\epsilon_{\mathrm{nH}}^{\lambda} 1}\right) t
$$

where $\epsilon_{\mathrm{OH}}^{\lambda}$ is the molar extinction coefficient of the hydroxyl radical at the wavelength, $\lambda$, of observation. $\epsilon_{\mathrm{OH}}^{\lambda}$ may be determined provided the dose is known, since the yields of $\mathrm{OH}$ and of $e_{\mathrm{aq}}^{-}$are accurately known. The absolute value for $k_{2}$ may then be determined from the slope of a straight line plot of $1 / D_{t}$ versus time. Since there is some contribution from the reaction

$$
\mathrm{OH}+\mathrm{H}=\mathrm{H}_{2} \mathrm{O} \text {, }
$$

this was taken into account in evaluating $k_{2}$.

The limitation on the application of this method stems from the fact that the absorption of $\mathrm{OH}$ is very weak and is in a region of the spectrum in which most solutes as well as $\mathrm{HO}_{2}$, an intermediate formed in the radiolysis, absorb rather strongly.

\section{Competition Kinetic Measurements}

Here only a relative rate constant can be determined.

\section{Stationary State Systems}

While it is true that the pulse radiolysis technique has provided most of the accurate $\mathrm{OH}$-rate data now available, much of the basic information concerning the general mechanisms of reaction of $\mathrm{OH}$ has derived from the considerable effort directed to the study of the stationary-state radiolysis of aqueous solutions. In such systems, irradiated at the dose rates available with conventional $\mathrm{x}$ - or $\gamma$-ray sources, the duration of the irradiation is many orders of magnitude greater than the lifetime of the $\mathrm{OH}$ radical formed under these conditions. Consequently, throughout the course of the radiolysis, this species is present at a constant, but extremely low, concentration. Its reactions cannot be observed directly and the determination of the reaction mechanisms depend entirely on the qualitative and quantitative estimation of the final, stable reaction products.

In aqueous solutions, therefore, the reactivity of the $\mathrm{OH}$ radical must be obtained by analysis of the yields and distribution of these final products. It can only be expressed relative to some other reference rate constant which itself has to be determined absolutely by some other method. The reliability of rate data so determined is dependent, therefore, on the accurate knowledge of the overall reaction mechanism. However, in spite of these difficulties, useful rate data have been obtained from stationary state kinetic competition analysis.

In principle, two general methods are employed for the determination of a relative rate constant for for reaction of $\mathrm{OH}$ with a given solute. In the first method, the kinetic analysis is based upon the effect of an additive on the yield of a stable product which results from reaction of $\mathrm{OH}$ with the solute. In the second, the competition is measured by the effect of the additive on the rate of removal or modification of the original solute.

The formic acid system [6] is an example of the former method. $\mathrm{OH}$ radicals react with this solute to form the carboxyl radical, $\mathrm{COOH}$ :

$$
\mathrm{OH}+\mathrm{HCOOH} \rightarrow \mathrm{H}_{2} \mathrm{O}+\mathrm{COOH} .
$$

In the presence of ferric ion, at low $\mathrm{pH}$, carboxyl radicals are oxidized to $\mathrm{CO}_{2}$ which can be collected and measured after the radiolysis is complete:

$$
\mathrm{COOH}+\mathrm{Fe}^{3+} \rightarrow \mathrm{CO}_{2}+\mathrm{Fe}^{2+}+\mathrm{H}^{+} .
$$

With a second solute present, which reacts competitively with $\mathrm{OH}$, the yield of $\mathrm{CO}_{2}$ will decrease.

If $G\left(\mathrm{CO}_{2}\right)$ is the radiation yield of carbon dioxide resulting entirely from reaction (12), then the effect on this yield of an added solute is given by the equation:

$$
\frac{1}{G\left(\mathrm{CO}_{2}\right)}=1+\frac{k_{x}[\mathrm{X}]}{k_{11}[\mathrm{HCOOH}]}
$$

where $[\mathrm{X}]$ is the concentration of the added solute and $k_{x}$ and $k_{11}$ are the respective rate constants for reaction of $\mathrm{OH}$ with each solute. The relative rate constant ratio $k_{x} / k_{11}$ is obtained from the data expressed graphically according to eq (13). 
Examples of the second type of stationary state competition system includes those in which the highly-colored compound, paranitrosodimethylaniline, PNDA [7], and the pyrimidine base, thymine [8-10], are used as reference solutes.

The compound PNDA has an intense optical absorption band with a maximum at $440 \mathrm{~nm}$ where the molar extinction coefficient is $3.42 \times 10^{4} \mathrm{M}^{-1}$ $\mathrm{cm}^{-1}$. The reaction product of $\mathrm{OH}$ with PNDA, believed to be an adduct radical, has a much weaker absorption at this wavelength. Consequently, irradiation of an aqueous solution of this compound leads to bleaching of the solution. In the presence of a second solute which can compete effectively for the $\mathrm{OH}$ radical, the extent of the bleaching is reduced. Simple kinetic analysis of the data yields the relative rate constant ratio for reaction of $\mathrm{OH}$ with the two solutes.

The thymine method is similar in principle to that employing PNDA as the reference solute. The presence of the 5:6 double bond in this molecule gives rise to a strong optical absorption band at $264 \mathrm{~nm}\left(\epsilon=7.95 \times 10^{3} M^{-1} \mathrm{~cm}^{-1}\right)$. It is well established that $\mathrm{OH}$ radicals add to the $5: 6$ double bond in thymine and, since this reaction destroys the chromophore, reaction of $\mathrm{OH}$ can be followed by direct measurement of the radiation-induced bleaching. Provided that the ultimate product of reaction of $\mathrm{OH}$ with a competitive solute does not contribute to the final absorption (or, if so, the extent of the contribution must be known) the relative rate constant for the solute can be determined.

Although both these competition methods have been used extensively, their reliability depends ultimately on the validity of the overall mechanisms assumed for the competition. Both solutes have been used, however, as reference standards for competition studies in pulse radiolysis where less emphasis need be placed on knowledge of the overall reaction mechanism. This is discussed later in chapter XI.

\section{Pulse Radiolysis Methods}

Several competition methods are available where the pulse radiolysis technique is used for obtaining relative $\mathrm{OH}$ rate data, although, as before, the validity of absolute rate constants derived from the data depends upon the accuracy with which the reactivity of $\mathrm{OH}$ with the reference solute can be determined.

As with the stationary state systems, two general spectrophotometric methods are available. In the event that the reference solute has suitable optical absorption properties, the reaction of $\mathrm{OH}$ radicals can be measured by observation of the bleaching of this absorption. The reaction of a competitive solute is indicated by a reduction in the extent of the bleaching, provided the transient product has a weaker absorption in the relevant region of the spectrum. Alternatively, the reference solute may react with $\mathrm{OH}$ to form a transient product with a much stronger absorption than the stable solute.
In this case, provided the product of $\mathrm{OH}$ reaction with the competitive solute does not absorb strongly in the same region, the competition is followed by measurement of the suppression of the transient absorption.

The competition kinetics of such systems are as follows: A solution containing a reference solute, $A$, of concentration [C] and a concentration [S] of a test solute $\mathrm{B}$ is irradiated by a short electron pulse. The $\mathrm{OH}$ radicals then react with either solute in proportion to the products of the concentration and rate constant of the respective reactions:

$$
\begin{gathered}
\mathrm{OH}+\mathrm{A} \stackrel{k_{a}}{\longrightarrow} \text { absorbing product } \\
\mathrm{OH}+\mathrm{B} \stackrel{k_{b}}{\longrightarrow} \text { nonabsorbing product. }
\end{gathered}
$$

If $A_{0}$ is the optical density of the absorbing product when solute $\mathrm{B}$ is absent and $A$ is the optical density when solute $B$ is present, then it follows that

$$
\frac{A_{o}}{A}=1+\frac{k_{b}[\mathrm{~S}]}{k_{a}[\mathrm{C}]} \text {. }
$$

A plot of $A_{o} / A$ against the ratio of solute concentrations is linear with the slope equal to $k_{b} / k_{a}$.

The rate constant $k_{b}$ can be derived, assuming that the reference rate constant, $k_{a}$, can be measured directly.

The carbonate radical, $\mathrm{CO}_{3}^{2-}$ was the first reference system used in pulse radiolysis for the determination of $\mathrm{OH}$ rate data $[11,12]$. The carbonate ion reacts with $\mathrm{OH}$ to form the transient radical, $\mathrm{CO}_{3}^{-}$, which has an absorption maximum at $600 \mathrm{~nm}$. Reaction of $\mathrm{OH}$ with a competitive solute suppresses this absorption band. An advantage of this system is that it can be used in aerated solution, although the drawbacks include the rather low extinction coefficient $\left(\epsilon^{500}=1.8 \times 10^{3} \mathrm{M}^{-1} \mathrm{~cm}^{-1}\right)$ and the obvious restriction to alkaline solutions.

Other systems were introduced in which the extinction coefficient of the reference absorption band is much higher. These include the halide and pseudohalide radicals, $\mathrm{I}_{2}^{-}$[4], and $(\mathrm{CNS})_{\overline{2}}^{-}[12]$, which have absorption maxima at $390 \mathrm{~nm}$ and $480 \mathrm{~nm}$ respectively. The serious disadvantage with systems of this type, which, in some cases may invalidate the method, is due to the fact that the reference absorptions are not formed in a one-step process. In the thiocyanate system, for example, the absorbing radical, (CNS $)_{2}^{-}$, is formed according to

$$
\begin{aligned}
& \mathrm{OH}+\mathrm{CNS}^{-} \rightarrow \mathrm{CNS}^{-} \\
& \mathrm{CNS}+\mathrm{CNS}^{-} \rightleftharpoons \mathrm{CNS}_{2}^{-} .
\end{aligned}
$$

It has been shown [13] that reaction (16) is somewhat slower than reaction (15) and is thus rate determining. Since the measured rate constant $\left(6.6 \times 10^{9}\right.$ $\left.M^{-1} \mathrm{~s}^{-1}\right)$ for the formation of the absorption refers 
to reaction (16), rate constants for other solutes measured by competition using this value are too low. Nevertheless, as will be discussed later, the large amount of published rate data for this system can be successfully normalized by arbitrary fitting with apparent self-consistency. Added kinetic complications which would arise if competition reactions of the uncomplexed CNS radical were to occur, seem to be unimportant in this system.

In similar competition studies where the $\mathrm{Br}_{2}^{-}$ absorption, formed from $\mathrm{OH}$ oxidation of bromide ions is used as the reference absorption, these complications are probably present [12]. The competition between carbonate and bromide ions for $\mathrm{OH}$ can be followed either by monitoring the $\mathrm{CO}_{3}^{-}$ absorption or that due to $\mathrm{Br}_{2}^{-}$. In either case, the rate constant for reaction of $\mathrm{OH}$ with $\mathrm{Br}^{-}$was found to be $1.8 \times 10^{8} M^{-1} \mathrm{~s}^{-1}$. However, the value obtained from direct observation of $\mathrm{Br}_{2}^{-}$formation is considerably larger. Pulse radiolysis systems in which the competition is measured by the effect of the second additive on the $\mathrm{OH}$-induced bleaching of an absorbing reference solute, have been used fairly successfully. Both the thymine and paranitrosodimethyl aniline methods, used originally under steady state conditions, have been adapted for use in pulse radiolysis experiments. As discussed previously, the validity of the stationary state experiments depends on the validity of the reaction mechanism assumed. However, in pulse radiolysis, since the competition is followed by direct observation of the extent of reaction between $\mathrm{OH}$ and the reference solute, subsequent radical reactions which could complicate the overall mechanism, become irrelevant.

A pulse radiolysis reference system which has much to commend it, is that in which ferrocyanide ion is used as the reference solute $[14,15]$. The ion is oxidized by $\mathrm{OH}$ rapidly and quantitatively in the simple, one-electron transfer reaction:

$$
\mathrm{OH}+\left[\mathrm{Fe}(\mathrm{CN})_{6}\right]^{4-} \rightarrow \mathrm{OH}^{-}+\left[\mathrm{Fe}(\mathrm{CN})_{6}\right]^{3-} \text {. }
$$

The product, ferricyanide ion, is stable and has a characteristic absorption band with a maximum at $410 \mathrm{~nm}\left(\epsilon^{410}=1000 \mathrm{M}^{-1} \mathrm{~cm}^{-1}\right)$. Further, it can be used over the entire range of $\mathrm{pH}$. Although radicals produced by reaction of $\mathrm{OH}$ with the competitive solute may, in some cases, react rapidly with the ferricyanide ion formed in (17) at the radiation doses which may be used in this technique, the rate of such reactions are still too slow to prevent accurate measurement of the initial values of the absorption.

\section{Intermittent Irradiation}

Intermittent irradiation [16] may be employed with application of the rotating sector method [17]. An absolute value for $k_{7}$ and a value for $k_{2}$ relative to $k_{7}$ have been determined by this method. The intermittency was provided by a pulsed, $1.5 \mathrm{MeV}$ Van de Graaff accelerator, with variable pulse length and variable frequency (although the off/on ratio was fixed at 7.5) with the period for a cycle variable from $10^{-5}$ to $5 \mathrm{~s}$. The product, of which the yield was measured, was hydrogen peroxide at steady state, $\left[\mathrm{H}_{2} \mathrm{O}_{2}\right]_{\mathrm{ss}}$, using intermittent irradiation and with a steady beam, $\left[\mathrm{H}_{2} \mathrm{O}_{2}\right]_{\mathrm{b}}$. Data were presented of $\left[\mathrm{H}_{2} \mathrm{O}_{2}\right]_{\mathrm{ss}} /\left[\mathrm{H}_{2} \mathrm{O}_{2}\right]_{\mathrm{b}}$ as a function of $\tau$, the pulse duration. With a risetime of $1 \mu$ s the pulse has a square waveform which simplifies the interpretation of rotating sector data.

A modification of the kinetic analysis normally used in the rotating sector method (in which product formation rate is proportional to the average concentration of the rate controlling transient) was necessary, since the concentration of measurable products here is at steady state. The analysis in. volves the overall mechanism for the water radiolysis. The experimental quantity, $\left[\mathrm{H}_{2} \mathrm{O}_{2}\right]_{\mathrm{ss}} /\left[\mathrm{H}_{2} \mathrm{O}_{2}\right]_{\mathrm{b}}$, is a complex function of (a) $\tau$ and the off/on ratio, (b) the beam intensity, (c) the relative rate and, hence, rate constants of the individual reactions, (d) the ratio $\left[\mathrm{O}_{2}\right] /\left[\mathrm{H}_{2} \mathrm{O}_{2}\right]$ under steady beam conditions and, (e) the yield of $\mathrm{OH}$ and of $\mathrm{H}_{2}$. The function is solved by trial and error by fitting to a curve of $\mathrm{H}_{2} \mathrm{O}_{2 \mathrm{ss}} /\left[\mathrm{H}_{2} \mathrm{O}_{2}\right]_{\mathrm{b}}$ versus $k_{2}\left[\mathrm{H}_{2} \mathrm{O}_{2}\right]_{\mathrm{b}} \tau$ from which the value for $k_{2}$ is found. Notwith. standing the complexity of the function used, the uncertainty in $k_{7}$ is only \pm 10 percent. Since $k_{2} / k_{7}^{2}$ is also obtained in this experiment, a relative value for the recombination rate constant is determined. The reader is referred to the original papers for the detailed interpretation of the data.

\section{Chapter III. References}

[1] Sauer, M. C., Jr., Argonne National Laboratory Report No. 7327, (May 1967).

[2] Boag, J. W., Trans. Faraday Soc. 64, 677 (1968).

[3] Thomas, J. K., Rabani, J., Matheson, M. S., Hart, E. J., and Gordon, S., J. Phys. Chem. 70, 2409 (1966).

[4] Thomas, J. K., Trans. Faraday Soc. 61, 702 (1965).

[5] Pagsberg, P., Christensen, H., Rabani, J., Nilsson, G., Fenger, J., and Nielsen, S. O., J. Phys. Chem. 73, 1029 (1969).

[6] Baxendale, J. H., and Smithies, D., Z. Phys. Chem. 7, 242 (1956).

[7] Kraljic, I., and Trumbore, C. N., J. Amer. Chem. Soc. 87, 2547 (1965).

[8] Ward, J. F., and Myers, L. S., Jr., Radiation Res. 26, 483 (1965).

[9] Scholes, G., and Willson, R. L., Trans. Faraday Soc. 63, 2983 (1967)

[10] Scholes, G., Shaw, P., Willson, R. L., and Ebert, M., in Pulse Radiolysis, ed. M. Ebert et al., p. 151 (Academic Press, London \& N.Y., 1965).

[11] Adams, G. E., and Boag, J. W., Proc. Chem. Soc. 112 (1964).

[12] Adams, G. E., Boag, J. W., and Michael, B. D., Trans. Faraday Soc. 61, 1417 (1965).

[13] Baxendale, J. H., Bevan, P. L. T., and Stott, D. A., Trans. Faraday Soc. 64, 2389 (1968).

[14] Adams, G. E., Boag, J. W., and Michael, B. D., Trans. Faraday Soc. 61, 492 (1965).

[15] Willson, R. L., Greenstock, C. L., Adams, G. E., Wageman, R., and Dorfman, L. M., Int. J. Radiat. Phys. and Chem. 3, 211 (1971).

[16] Schwarz, H. A., J. Phys. Chem. 66, 255 (1962).

[17] Burnett, M., and Melville, H. W., Techniques of Organic Chem., Vol. 8, A. Weissberger, Ed. (Interscience Pub., New York, N.Y. 1953). 


\section{Chapter IV. Physical Properties and Chemical Equilibrium}

Those physical properties of the hydroxyl radical in water which pertain most directly to its chemical reactivity are the $p K$ for its ionic dissociation, which has been accurately determined, and its diffusion coefficient, which has been estimated. Several other properties, such as the optical absorption spectrum, electron paramagnetic resonance absorption spectrum, and electron affinity which are also known, are given here.

The hydroxyl radical is a neutral free radical. The determination that it bears zero charge when formed in water radiolysis was made in two ways, by comparison of the reactivity [1] of $\mathrm{OH}$ produced in radiolysis with that produced photochemically and by the use of tests of the kinetic salt effect [2]. In the former, the chemical behavior of photolytic and radiolytic $\mathrm{OH}$ was shown to be the same; in the latter experiments the absence of any kinetic salt effect showed that the oxidizing species in water radiolysis bore zero charge. This conclusion was an important step in identifying the species as $\mathrm{OH}$. The formation of hydroxyl radicals in irradiated ice and in various irradiated hydrated crystals, has also been shown $[3,4]$ from its ESR spectrum at $4.2 \mathrm{~K}$ and $77 \mathrm{~K}$. This spectrum consists of an asymmetric doublet in accord with the interaction of the unpaired electron with the hydrogen atom. The isotropic hyperfine splitting in ice was $-26.3 \mathrm{Oe}$ compared with $-26.7 \mathrm{Oe}$ in the vapor phase [5] and a calculated value [6] of -24.2 Oe. This observation of $\mathrm{OH}$ in irradiated ice further supports the conclusion that it is formed in water, but to the best of our knowledge, the ESR spectrum has not been observed in the liquid phase, very likely because of the low steady state concentration and short lifetime.

The electron affinity of the hydroxyl radical in the gas phase does not appear to be known accilrately, and experimental estimates cover a substantial range. A value $[7,8]$ of about $2 \mathrm{eV}$ or slightly higher, seems to be correct. The heat of hydration of the hydroxide ion is estimated [9] to be about $88 \mathrm{kcal} / \mathrm{mol}$. The sum of this value and the electron affinity of $\mathrm{OH}$ in the gas phase would then place the electron affinity of $\mathrm{OH}$ in water at about $5.8 \mathrm{eV}$.

The hydroxyl radical behaves like a weak acid, undergoing ionic dissociation in strongly basic solution:

$$
\mathrm{OH}+\mathrm{OH}^{-} \rightleftharpoons \mathrm{O}^{-}+\mathrm{H}_{2} \mathrm{O} \text {. }
$$

The $p K$ for this equilibrium is $11.9 \pm 0.2$. Since $\mathrm{O}^{-}$, the basic form of the hydroxyl radical, exhibits substantially different chemical reactivity than the more familiar form, $\mathrm{OH}$, we may expect the apparent reactivity of the hydroxyl radical to show a marked $\mathrm{pH}$-dependence in the region of $\mathrm{pH}$ from about 10.5 to 13 .

This difference in reactivity was, in fact, used [10] to determine the $p K$ in the following way. The reactivity of $\mathrm{OH}$ with ferrocyanide is much greater that that of $\mathrm{O}^{-}$.

$$
\begin{gathered}
\mathrm{OH}+\left[\mathrm{Fe}(\mathrm{CN})_{6}\right]^{4-}=\mathrm{OH}^{-}+\left[\mathrm{Fe}(\mathrm{CN})_{6}\right]^{3-}, \\
\mathrm{O}^{-}+\left[\mathrm{Fe}(\mathrm{CN})_{6}\right]^{4-} \stackrel{\mathrm{H}_{2} \mathrm{O}}{=} 2 \mathrm{OH}^{-}+\left[\mathrm{Fe}(\mathrm{CN})_{6}\right]^{3-} .
\end{gathered}
$$

This rate of formation of ferricyanide ion was observed by pulse radiolysis as a function of $\mathrm{pH}$ in the appropriate range. With $k_{2} \gg k_{3}$, the following equation holds:

$$
\log \left(k_{2} / k-1\right)=\mathrm{pH}-p K
$$

where $k$ is the apparent rate constant for reaction of both $\mathrm{OH}$ and $\mathrm{O}^{-}$. The data gave $p K=11.9 \pm 0.2$. This was also confirmed in later experiments in which the reactivity of hydroxyl with carbonate ion was studied [11], which gave $p K=11.8 \pm 0.2$ and with thiocyanate ion [12] which gave $p K=11.9 \pm 0.15$.

The reverse of (1), the reaction of $\mathrm{O}^{-}$to form $\mathrm{OH}$, involves a water molecule rather than the hydronium ion which is present in very low concentration at such high $\mathrm{pH}$.

The reactions of $\mathrm{OH}$ and of $\mathrm{O}^{-}$are listed in separate chapters in this compendium, where the difference in reactivities may be readily compared. These differences in reactivity with compounds such as oxygen and aromatic molecules are so large as to be qualitative.

The hydroxyl radical in water appears to show a weak optical absorption in the far ultraviolet, which has been recorded in pulse radiolysis studies [13-15]. In the gas phase, $\mathrm{OH}$ exhibits a series of fairly strong absorption bands [16] at 280 to $306 \mathrm{~nm}$. In water, a weak absorption, which is thought to be that of the hydroxyl radical, is seen, starting at about $300 \mathrm{~nm}$ and increasing at shorter wavelengths to $200 \mathrm{~nm}$, the limit of measurements made. This absorption, which seems to be continuous, is shown in figure 2 in which data from two groups of investigators is included. If any fine structure existed, it would not likely be seen in such spectrophotometric measurements with a relatively large band pass. The identification of this absorption with $\mathrm{OH}$ is based upon two observations: 


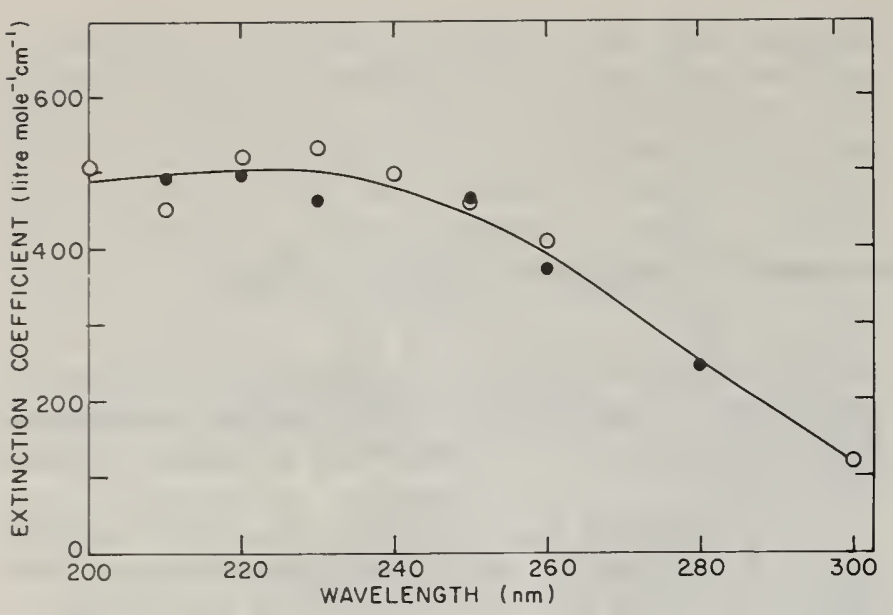

FIGLRE 2. The absorption spectrum attributed to the hydroxyl radical in water obtained by pulse'radiolysis of aqueous solutions containing either $\mathrm{N}_{2} \mathrm{O}$ or $\mathrm{H}_{2} \mathrm{O}_{2}$ to scavenge the hydrated electron.

The molar extinction coefficient is plotted against wavelength. $\bigcirc \mathrm{D}$ ata from reference [15], chapter IV, in which the solution contains $2 \mathrm{mM} \mathrm{N} \mathrm{N}_{2} \mathrm{O}$, and the absorption is corrected for $\mathrm{H}_{2} \mathrm{O}_{2}, \mathrm{H}$ and $\mathrm{OH}^{-}$. Data from reference [13], chapter IV, in which the solution contains either $1 \mathrm{~m} M \mathrm{~N}_{2} \mathrm{O}$ or $0.2 \mathrm{mM} \mathrm{H} \mathrm{H}_{2} \mathrm{O}_{2}$, and the absorption is corrected for $\mathrm{H}_{2} \mathrm{O}_{2}$.

(1) with $\mathrm{N}_{2} \mathrm{O}$ present, the optical density is doubled in accord with the conversion of $e_{\mathrm{aq}}^{-}$to $\mathrm{OH}$ and, (2) the decay kinetics of the absorption in this system in which $[\mathrm{OH}]_{0} /[\mathrm{H}]_{0} \cong 10$, and there are, ostensibly, no other radicals present, gives values for $k_{\mathrm{OH}+\mathrm{OH}}$ and $k_{\mathrm{OH}+\mathrm{H}_{2}}$ in quite good agreement with the values obtained by other methods. Molar extinction coefficients of $370 \mathrm{M}^{-1} \mathrm{~cm}^{-1}$ at $260 \mathrm{~nm}$ [13] and $530 \mathrm{M}^{-1} \mathrm{~cm}^{-1}$ at $230 \mathrm{~nm}$ [15], in fairly good agreement, have been reported from the two laboratories. The suggestion has been made [15] that this absorption is a red-shift of the water continuum resulting from a partial electron transfer from the first excited singlet state of water to a neighboring $\mathrm{OH}$ radical.

It should be understood that experiments in this spectral region, involving as they do a weakly absorbing transient, are difficult and complex in that there are overlapping absorptions from species such as $\mathrm{H}, \mathrm{OH}^{-}$, and $\mathrm{H}_{2} \mathrm{O}_{2}$. However, appropriate corrections [15] have been made and the agreement in the observation lends confidence to the validity of the assignment. The existence of the absorption maximum reported [15], does, however, depend upon the optical density measurement at a single wavelength. A somewhat similar absorption thought to be that of $\mathrm{O}^{-}$has been observed [17] in strongly basic solution, but no definitive evidence for the assignment has been obtained.

The diffusion coefficient of the hydroxyl radical in water was estimated [18] from the value determined for the rate constant of the reaction of hydroxyl radical with catalase, which is $8.3 \times$ $10^{10} \mathrm{M}^{-1} \mathrm{~s}^{-1}$ at $25^{\circ} \mathrm{C}$. The diffusion coefficient was obtained from this value and from the Smoluchowski [19] equation on the assumption that the reac- tion was diffusion-controlled and that the catalase was stationary, with $\mathrm{OH}$ being the only diffusing partner. With the reasonable approximation that the sum of the radii of interaction is equal to the molecular radius of the catalase molecule, a value of $2.3 \times 10^{-5} \mathrm{~cm}^{2} \mathrm{~s}^{-1}$ at $25^{\circ} \mathrm{C}$ was estimated for the diffusion coefficient. The assumption is also inherent in taking the rate constant to be diffusioncontrolled, that no factor of geometry is involved in the value for the specific rate. If this were not the case, the value determined would then represent a lower limit for the diffusion coefficient of $\mathrm{OH}$. $\mathrm{OH}$.

Table 1 summarizes these physical properties of

TABLE 1. Physical properties of $\mathrm{OH}$ in water

\begin{tabular}{ll}
\hline \hline Optical absorption & $\begin{array}{l}\text { at } \lambda \leqslant 300 \mathrm{~nm} \\
\epsilon^{260}=370 M^{-1} \mathrm{~cm}^{-1} \\
\epsilon^{230}=530 M^{-1} \mathrm{~cm}^{-1} \\
11.9 \pm 0.2\end{array}$ \\
Molar extinction coefficient & $2.3 \times 10^{-5} \mathrm{~cm}^{2} \mathrm{~s}^{-1}$ \\
Diffusion coefficient & Doublet \\
ESR spectrum (ice) & $2 \mathrm{eV}$ \\
Electron affinity (gas phase) & $5.8 \mathrm{eV}$ \\
Electron affinity (aqueous-calc.) & $0.44 \mathrm{eV}$ \\
Heat of ionization ${ }^{20}$ & \\
\hline
\end{tabular}

\section{Chapter IV. References}

[1] Hochanadel, C. J., Radiation Res. 17,286 (1962).

[2] Hummel, A., and Allen, A. O., Radiation Res. 17, 302 (1962).

[3] Matheson, M. S., and Smaller, B., J. Chem. Phys. 23, 521 (1955).

[4] Gunter, T. E., J. Chem. Phys. 46, 3818 (1967).

[5] Radford, H. E., Phys. Rev. 126, 1035 (1962).

[6] Kayama, K., J. Chem. Phys. 39, 1507 (1963).

[7] Page, F. M., Advances in Chemistry Series No. 36, Free Radical in Inorganic Chemistry, p. 68 (1962).

[8] Branscomb, L. M., and Smith, S. J., Phys. Rev. 99, 1657 (1955).

[9] Benjamin, L., and Gold, V., Trans. Faraday Soc. 50, 797 (1954).

[10] Rabani, J., and Matheson, M. S., J. Phys. Chem. 70, 76] (1966).

[11] Weeks, J. L., and Rabani, J., J. Phys. Chem. 70, 2100 (1966).

[12] Adams, G. E., Boag, J. W., Currant, J., and Michael, B. D., in Pulse Radiolysis, p. 117, ed. M. Ebert et al. (Academic Press, London and New York, 1965).

[13] Thomas, J. K., Rabani, J., Matheson, M. S., Hart, E. J., and Gordon, S., J. Phys. Chem., 70, 2409 (1966).

[14] Thomas, J. K., Trans. Faraday Soc. 61, 702 (1965).

[15] Pagsberg, P., Christensen, H., Rabani, J., Nilsson, G., Fenger, J., and Nielsen, S. O., J. Phys. Chem. 73, 1029 (1969).

[16] Oldenberg, O., and Rieke, F. F., J. Chem. Phys. 6, 439 (1938).

[17] Boag, J. W., and Adams, G. E., Cellular Radiation Biology, p. 64 (The Williams and Wilkins Co., Baltimore, 1965).

[18] Henglein, A., Karmann, W., Roebke, W., and Beck, G., Makromolekulare Chemie 92, 105 (1966).

[19] Smoluchowski, M. V., Z. Physik. Chem. 92,129 (1918).

[20] Baxendale, J. H., Ward, M. D., and Wardman, P., Trans. Farad. Soc. 67, 2532 (1971). 


\section{Chapter V. Addition Reactions}

Hydroxyl radicals add very readily to aromatic molecules to form the corresponding hydroxycyclohexadienyl radicals and to unsaturated aliphatic compounds to form hydroxyalkyl radicals. Observation of the rate curve for formation of the cyclohexadienyl radicals in pulse radiolysis, the spectra of which were first reported [2] for benzene and a series of substituted benzenes, permits the determination of absolute rate constants for these reactions. The various substituted cyclohexadienyl radicals which may be formed exhibit a strong optical absorption in the uv and, therefore, represent a convenient transient product for monitoring the reaction. Rate constants have thus been determined absolutely for addition to compounds such as benzene [1, 2], benzoic acid [3], hydroxybenzenes [4], nitrobenzene [5] and many others.

$$
\begin{gathered}
\mathrm{OH}+\mathrm{C}_{6} \mathrm{H}_{6}=(\mathrm{OH}) \mathrm{C}_{6} \mathrm{H}_{6} \cdot \\
\mathrm{OH}+\mathrm{C}_{6} \mathrm{H}_{5} \mathrm{COOH}=(\mathrm{OH}) \dot{\mathrm{C}}_{6} \mathrm{H}_{5} \mathrm{COOH} .
\end{gathered}
$$

The occurrence of such addition reactions, which compete overwhelmingly with hydrogen abstraction from these molecules, was first demonstrated by kinetic and isotopic studies [1] and confirmed by ESR observation [6] of the hydroxycyclohexadienyl radical in a flow system in which $\mathrm{OH}$ was generated chemically by the reaction of titaneous ion with hydrogen peroxide. However, just as the hydroxyl radical adds readily in reactions (1) and (2), so does the hydrogen atom add readily to form cyclohexadienyl radicals.

$$
\begin{gathered}
\mathrm{H}+\mathrm{C}_{6} \mathrm{H}_{6}=\mathrm{C}_{6} \mathrm{H}_{7} \cdot, \\
\mathrm{H}+\mathrm{C}_{6} \mathrm{H}_{5} \mathrm{COOH}=\cdot \mathrm{C}_{6} \mathrm{H}_{6} \mathrm{COOH} .
\end{gathered}
$$

The hydroxycyclohexadienyl radicals and the cyclohexadienyl radicals of the same compound exhibit rather similar, overlapping optical absorption spectra with molar extinction coefficients of comparable magnitude [2-5]. Consequently, any attempt to observe the reaction by monitoring the optical absorption in a system containing both hydroxyl radicals and hydrogen atoms will result in monitoring both $\mathrm{OH}$-addition and $\mathrm{H}$-addition concurrently. Since the rate constants for $\mathrm{OH}$-addition are, in general, somewhat different from those for $\mathrm{H}$-atom addition, unless the conditions of the system are arranged to resolve the reactions of the hydroxyl radicals or the hydrogen atoms, a composite of the two rate constants will be obtained. Moreover, the hydrated electron may also react with the solute molecule to complicate the system even further by the formation of a transient with an overlapping absorption unless these complications are eliminated.

These complications have been eliminated, in the case of the reactants cited [2-5], as well as for many other reactants, by the use of selective scavengers. The hydrated electron has been scavenged by the use of $\mathrm{N}_{2} \mathrm{O}$ in many systems.

$$
\begin{gathered}
e_{\mathrm{aq}}^{-}+\mathrm{N}_{2} \mathrm{O}=\mathrm{N}_{2}+\mathrm{O}^{-}, \\
\mathrm{O}^{-}+\mathrm{H}_{2} \mathrm{O}=\mathrm{OH}+\mathrm{OH}^{-} .
\end{gathered}
$$

As has been pointed out in chapter II, this converts the system almost completely to a one-radical system with $[\mathrm{OH}]_{0} /[\mathrm{H}]_{0} \cong 10$, in which rate constants such as $k_{1}$ and $k_{2}$ may be determined accurately with only a small correction for the effect of the concurrent reactions (3) and (4) respectively. This correction may, nevertheless, amount to as much as 5 to 8 percent, depending on the particular compound and the experimental conditions. Oxygen has also been used [5] as a scavenger to remove both $e_{\mathrm{aq}}^{-}$and $\mathrm{H}$ to form a relatively unreactive transient.

$$
\begin{aligned}
& e_{\mathrm{aq}}^{-}+\mathrm{O}_{2}=\mathrm{O}_{2}^{-}, \\
& \mathrm{H}+\mathrm{O}_{2}=\mathrm{HO}_{2} .
\end{aligned}
$$

$k_{3}, k_{4}$, and other rate constants for analagous addition reactions of hydrogen atoms, the values of which are needed to provide accurate, if small, corrections in determining $k_{1}$ and $k_{2}$, have been determined from experiments in which $\mathrm{OH}$ radicals are eliminated by the use of selective scavengers such as deuteromethanol $[2,3]$ or thallous ion [5]. With such necessary attention to the details of the system, rate constants with an uncertainty as low as \pm 15 percent have been determined for many $\mathrm{OH}$-addition reactions. Some rate constants for $\mathrm{OH}$-addition reactions have also been determined from competition kinetic studies in pulse radiolysis as well as in steady state irradiations. The values obtained by all these methods, along with pertinent information about the conditions are given in table 2 , page $17 .^{3}$

One such condition, the $\mathrm{pH}$ of the solution, is particularly worthy of note since it may affect the value of the rate constant. Many of the compounds listed in table 2 undergo an ionic dissociation, for

${ }^{3}$ All subsequent tables are placed at the end of the chapter in which they are discussed. See contents for page numbers of specific tables. 
which the equilibrium is $\mathrm{pH}$-dependent. The rate constant for $\mathrm{OH}$-addition may be different, as for benzoic acid and benzoate ion [3], for the neutral molecular form and the molecule ion. Consequently, the $\mathrm{pH}$ of the solution must be accurately known, especially in the range near the $p K$ of the reactant molecule if an ionic dissociative equilibrium occurs.

There is a complication inherent in many of these addition reactions, the details of which are difficult to determine and which has, consequently, not been adequately defined for most of the reactants in table 2. For substituted aromatic compounds, or polycyclic compounds, a number of different isomeric hydroxycyclohexadienyl radicals may be formed by the addition of the hydroxyl radical. The determination of the rate constant for $\mathrm{OH}$-addition by observation of the transient product in pulse radiolysis, or by competition studies, reveals only the value for the overall rate constant, and not the separate rate constants for formation of the individual isomers in concurrent reactions. The absence of this information in no way invalidates the rate constants in table 2 , which are thus the sum of rate constants for such individual reactions. For those compounds about which information on the isomeric distribution has been obtained, the details are given in the table.

Rate constants have been determined for a sufficient variety of substituted aromatic compounds to permit some assessment to be made of the effect of substituent groups upon the reactivity of aromatic compounds toward hydroxyl radicals. Such an assessment of the rates of $\mathrm{OH}$-addition as an electrophilic substitution reaction has been presented $[7,8]$ in terms of the Hammeit equation [9],

$$
\log \frac{k_{\mathrm{OH}}+\mathrm{PhX}}{k_{\mathrm{OH}}+\mathrm{PhH}}=\sigma \rho,
$$

where $\sigma$ is a substituent constant defined by the $\log$ of the ratio of the acidity constant for a substituted benzoic acid to the acidity constant for benzoic acid, and $k_{\mathrm{OH}+\mathrm{Phx}}$ and $k_{\mathrm{OH}+\mathrm{PhH}}$ are the $\mathrm{OH}$ addition rate constants for the substituted benzene respectively. $\rho$ is a constant for the specific reaction. Figure 3 shows [8] a plot of the $\sigma$-values for a number of mono-substituted benzenes and $p$-substituted benzoate ions as a function of $\log \frac{k_{\mathrm{OH}}+\mathrm{Phx}}{k_{\mathrm{OH}+\mathrm{PhH}}}$ using a set of absolute rate constants. The data indicate a correlation with a value $\rho=0.5$ obtained from the slope, suggesting that the addition reaction is an electrophilic substitution. There may be some question about the significance of this empirical correlation in view of the fact that the rate constants cover a relatively small range, are all fairly close to the diffusion controlled limit, and show a substantial degree of scatter of the data presented $[7,8]$ in such a plot.

Many of the foregoing studies, in which the rates of formation and the optical absorption spectra of a great variety of cyclohexadienyl radicals have been determined, have been quite successfully directed toward the exposition of the properties of these radicals. Thus, information has been obtained about the dimerization, the detachment of water from hydroxy- and dihydroxycyclohexadienyl radicals, the $p K$ of many of the radicals formed, and the slow decomposition of the dimers of the cyclohexadienyl radicals. These properties, although important to an understanding of the chemistry of the systems, are not our concern in this monograph.

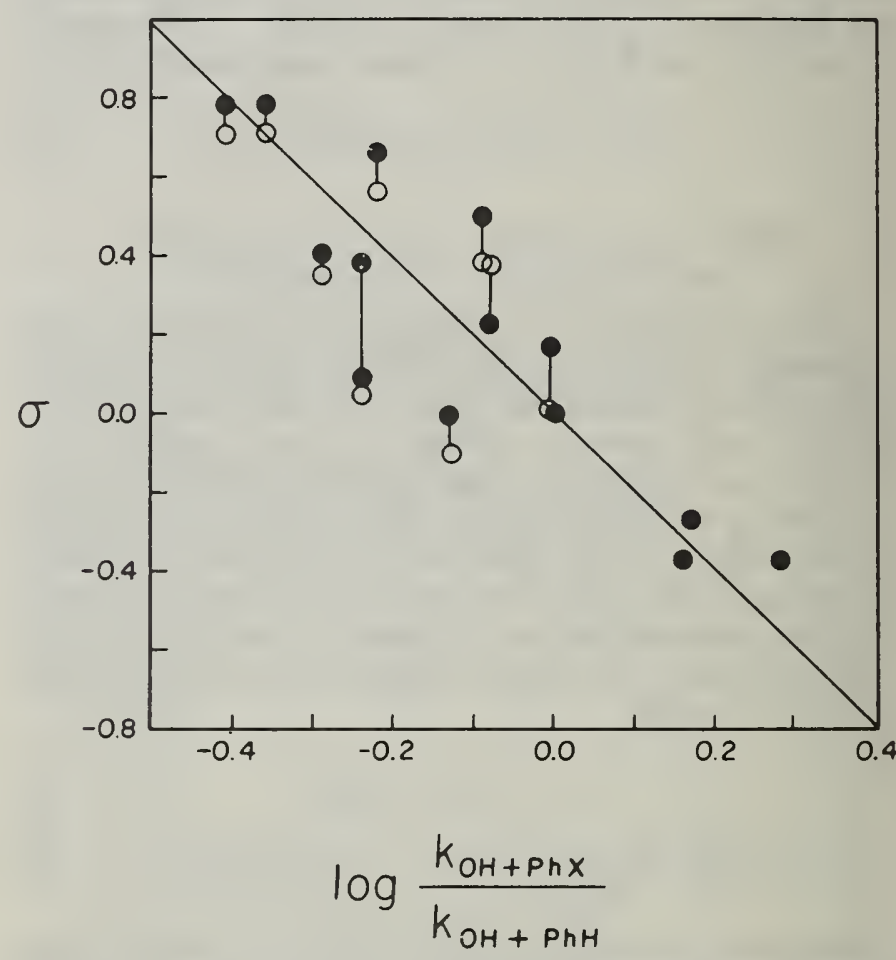

FIgURE 3. Correlation of rate constants for hydroxyl radical addition reactions with Hammett's equation.

The value for the Hammett $\sigma$ is plotted against the value of the Hammett function in which $k_{\mathrm{OH}+\mathrm{PhX}}$ is the rate constant for the monosubstituted benzene or the $p$-substituted benzoic acid and $k_{\mathrm{OH}+\mathrm{PhH}}$ is the rate constant for benzene or benzoic acid. 
TABLE 2. Addition reactions

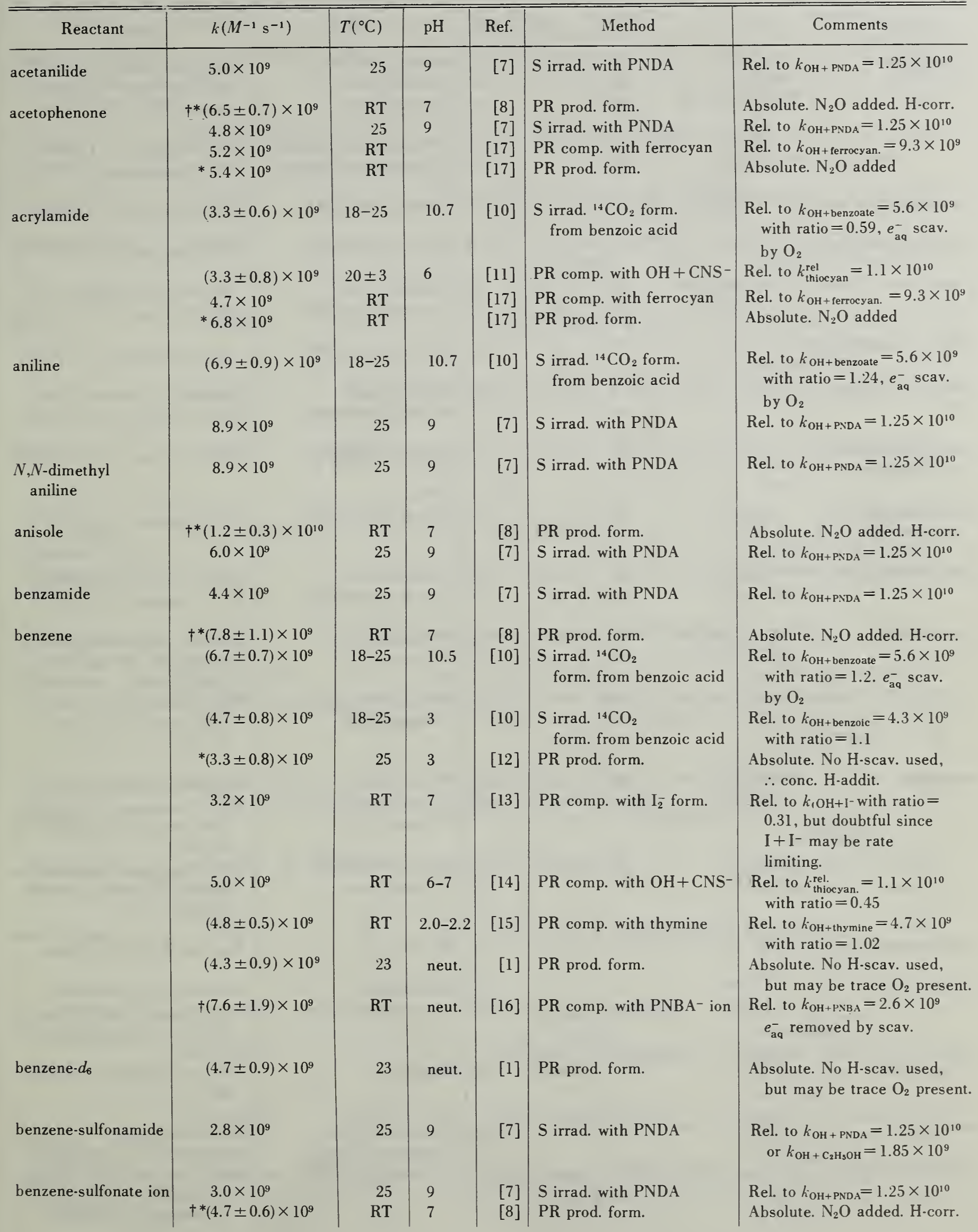


TABLE 2. Addition reactions-Continued

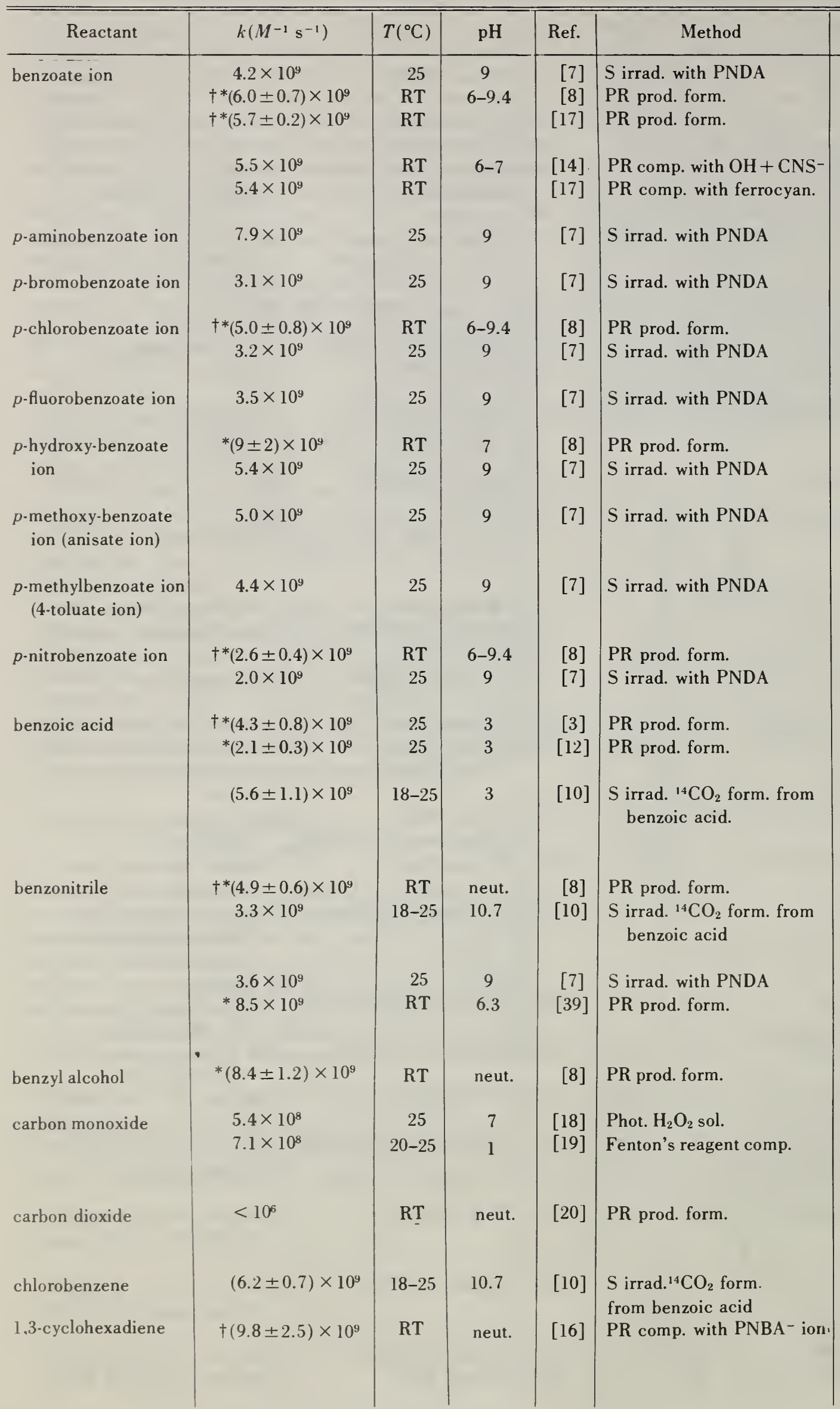

Rel. to $k_{\mathrm{OH}}+\mathrm{PNDA}=1.25 \times 10^{10}$ Absolute. $\mathrm{N}_{2} \mathrm{O}$ added. $\mathrm{H}$-corr. Absolute. $\mathrm{N}_{2} \mathrm{O}$ added. No $\mathrm{H}$ corr.

Rel. to $k_{\text {thiocyan. }}^{\text {rel. }}=1.1 \times 10^{10}$

Rel. to $k_{\mathrm{OH}+\text { ferrocyan. }}=9.3 \times 10^{9}$

Rel. to $k_{\mathrm{OH}+\mathrm{PNDA}}=1.25 \times 10^{10}$

Rel. to $k_{\mathrm{OH}+\mathrm{PNDA}}=1.25 \times 10^{16}$

Absolute. $\mathrm{N}_{2} \mathrm{O}$ added. $\mathrm{H}$-corr. Rel. to $k_{\mathrm{OH}+\mathrm{PNDA}}=1.25 \times 10^{10}$

Rel. to $\mathrm{k}_{\mathrm{OH}+\mathrm{PNDA}}=1.25 \times 10^{10}$

Absolute. $\mathrm{N}_{2} \mathrm{O}$ added. $\mathrm{H}$-corr. Rel. to $k_{\mathrm{OH}+\mathrm{PNDA}}=1.25 \times 10^{10}$

Rel. to $k_{\mathrm{OH}+\mathrm{PNDA}}=1.25 \times 10^{10}$

Rel. to $k_{\mathrm{OH}+\mathrm{PNDA}}=1.25 \times 10^{10}$

Absolute. $\mathrm{N}_{2} \mathrm{O}$ added. $\mathrm{H}$-corr. Rel. to $k_{\mathrm{OH}+\mathrm{PNDA}}=1.25 \times 10^{10}$

Absolute. $\mathrm{N}_{2} \mathrm{O}$ added. H-corr. Absloute. No. H-scav. used : conc. $\mathrm{H}$-addit.

Rel. to $k_{\mathrm{OH}+\text { benzoate }}=5.6 \times 10^{9}$ with ratio $=1.0, e_{\mathrm{aq}}^{-}$scav. by $\mathrm{O}_{2}$

Absolute. $\mathrm{N}_{2} \mathrm{O}$-added. $\mathrm{H}$-corr. Rel. to $k_{\mathrm{OH}+\text { benzoate }}=5.6 \times 10^{9}$ with ratio $=0.59, e_{\mathrm{aq}}^{-}$scav. by $\mathrm{O}_{2}$

Rel. to $k_{\mathrm{OH}+\mathrm{PNDA}}=1.25 \times 10^{10}$

Absolute. $\mathrm{N}_{2} \mathrm{O}$ added. No corr. $\mathrm{H}$-atom

Absolute. $\mathrm{N}_{2} \mathrm{O}$-added. $\mathrm{H}$-corr.

Rel. to $k_{\mathrm{OH}+\mathrm{H}_{2} \mathrm{O}_{2}}=4.5 \times 10^{7}$

Rel. to $k_{\mathrm{OH}+\mathrm{Fe}^{2+}}=3.3 \times 10^{8}$ with ratio $=2.14$

Absence of transient prod. sets limit

Rel. to $k_{\mathrm{OH}+\text { benzoate }}=5.6 \times 10^{9}$ with ratio $=1.1, e_{a q}^{-}$scav. by $\mathrm{O}_{2}$ Rel. to $k_{\mathrm{OH}}+\mathrm{PNBA}=2.6 \times 10^{9} e_{\mathrm{aq}}^{-}$ removed by scav. $\mathrm{H}$ abstraction amounts to 30 percent 
TABLE 2. Addition reactions-Continued

\begin{tabular}{|c|c|c|c|c|c|c|}
\hline Reactant & $k\left(M^{-1} \mathrm{~s}^{-1}\right)$ & $T\left({ }^{\circ} \mathrm{C}\right)$ & $\mathrm{pH}$ & Ref. & Method & Comments \\
\hline 1,4-cyclohexadiene & $\dagger(7.7 \pm 1.9) \times 10^{9}$ & RT & neut. & {$[16]$} & PR comp. with $\mathrm{PNBA}^{-}$ion & $\begin{array}{l}\text { Rel. to } k_{\mathrm{OH}+\mathrm{PNBA}}=2.6 \times 10^{9} e_{\mathrm{aq}}^{-} \\
\text {removed by scav. } \mathrm{H} \text {-abstrac- } \\
\text { tion amounts to } 45 \text { percent }\end{array}$ \\
\hline cyclohexene & $(8.8 \pm 2.2) \times 10^{9}$ & RT & neut. & {$[16]$} & PR comp. with $\mathrm{PNBA}^{-}$ion & $\begin{array}{l}\text { Rel. to } k_{\mathrm{OH}+\mathrm{PNBA}}-=2.6 \times 10^{9} \\
e_{\mathrm{aq}}^{-} \text {removed by scav. }\end{array}$ \\
\hline dimethylsulfoxide & $7.1 \times 10^{9}$ & RT & neut. & {$[20]$} & PR comp. with $\mathrm{OH}+\mathrm{CNS}^{-}$ & Rel. to $k_{\text {thiocyan. }}^{\text {rel. }}=1.1 \times 10^{10}$ \\
\hline dimethylthioether & $8.7 \times 10^{9}$ & RT & neut. & {$[20]$} & $\begin{array}{l}\text { PR comp. with } \mathrm{OH}+ \\
\text { methanol }\end{array}$ & $\begin{array}{l}\text { Rel. to } k_{\text {thiocyan. }}^{\text {rel. }}=1.1 \times 10^{10} \\
\text { with ratio }=0.79, \text { as sec- } \\
\text { ondary standard }\end{array}$ \\
\hline \multirow[t]{2}{*}{ dioxane } & $2.4 \times 10^{9}$ & RT & 7 & {$[13]$} & PR comp. with $I_{2}^{-}$form. & $\begin{array}{l}\text { Rel. to } k_{\mathrm{OH}+\mathrm{I}^{-}} \text {with ratio }=0.23, \\
\text { but doubtful since } \mathrm{I}+\mathrm{I}^{-} \text {may } \\
\text { be rate limiting }\end{array}$ \\
\hline & $1.7 \times 10^{9}$ & RT & $2.0-2.2$ & {$[15]$} & PR comp. with thymine & $\begin{array}{l}\text { Rel. to } k_{\mathrm{OH}+\text { thymine }}=4.7 \times 10^{9} \\
\text { with ratio }=0.37\end{array}$ \\
\hline ethylene & $1.8 \times 10^{9}$ & RT & $\begin{array}{l}\text { neut. } \\
\text { and } \\
\text { acid }\end{array}$ & $\begin{array}{l}{[21]} \\
{[22]}\end{array}$ & PR comp. with $\mathrm{OH}+\mathrm{CNS}^{-}$ & $\begin{array}{l}\text { Rel. to } k_{\text {thiocyan. }}^{\text {rel. }}=1.1 \times 10^{10} \\
\text { Calc. although details not } \\
\text { given }\end{array}$ \\
\hline $\begin{array}{l}p \text {-hydroxynitro- } \\
\text { benzene ( } p \text {-nitro- } \\
\text { phenol) }\end{array}$ & $\dagger^{*}(3.8 \pm 0.6) \times 10^{9}$ & RT & 1.3 & {$[23]$} & PR prod. form. & $\begin{array}{l}\text { Absolute. } \mathrm{N}_{2} \mathrm{O} \text { added. } \\
\text { Evidence indicates reac. } \\
\text { is not addition, but with } \\
\text { nitro group }\end{array}$ \\
\hline hydroquinone & $2.1 \times 10^{10}$ & RT & $6-7$ & {$[14]$} & PR comp. with $\mathrm{OH}+\mathrm{CNS}^{-}$ & Rel. to $k_{\text {thiocyan. }}^{\text {rel. }}=1.1 \times 10^{10}$ \\
\hline \multirow[t]{3}{*}{ nitrobenzene } & $\begin{array}{l}\dagger^{*}(3.2 \pm 0.4) \times 10^{9} \\
3.4 \times 10^{9}\end{array}$ & $\begin{array}{l}\mathrm{RT} \\
25\end{array}$ & $\begin{array}{c}\text { neut. } \\
9\end{array}$ & $\begin{array}{l}{[8]} \\
{[7]}\end{array}$ & $\begin{array}{l}\text { PR prod. form. } \\
S \text { irrad. with PNDA }\end{array}$ & $\begin{array}{l}\text { Absolute. } \mathrm{N}_{2} \mathrm{O} \text { added. } \mathrm{H} \text {-corr. } \\
\text { Rel. to } k_{0 \mathrm{H}+\mathrm{P}^{\mathrm{NDA}}}=1.25 \times 10^{10}\end{array}$ \\
\hline & $2.2 \times 10^{9}$ & $18-25$ & 10.5 & {$[10]$} & $\begin{array}{l}\mathrm{S} \text { irrad. }{ }^{14} \mathrm{CO}_{2} \text { form. from } \\
\text { benzoic acid }\end{array}$ & $\begin{array}{l}\text { Rel. to } k_{\mathrm{OH}+\text { henzoate }}=5.6 \times 10^{9} \\
\text { with ratio }=0.39 . e_{\text {:iq }}^{-} \text {scav. } \\
\text { by } \mathrm{O}_{2}\end{array}$ \\
\hline & $\dagger^{*}(4.7 \pm 0.5) \times 10^{9}$ & RT & 1 & {$[5]$} & PR prod. form. & Absolute. $\mathrm{O}_{22}$ to scav. $e_{\mathrm{aq}}^{-}$ \\
\hline nitromethane & $<9 \times 10^{6}$ & 'RT & neut. & {$[24]$} & PR comp. with $\mathrm{OH}+\mathrm{CNS}^{-}$ & $\begin{array}{l}\text { Rel. to } k_{\text {thiocyan }}^{\text {rel. }}=1.1 \times 10^{10} \\
\text { Upper limit only }\end{array}$ \\
\hline nitromethane anion & $\dagger^{*}(8.5 \pm 1.5) \times 10^{9}$ & RT & neut. & {$[25]$} & PR prod. form. & $\begin{array}{l}\text { Absolute. Addit. reac. with } \\
\text { anionic form of molecule }\end{array}$ \\
\hline nitrosobenzene & $1.9 \times 10^{10}$ & RT & neut. & {$[26]$} & PR comp. with $\mathrm{OH}+\mathrm{CNS}^{-}$ & $\begin{array}{l}\text { Rel. to } k_{\text {thiocyan. }}^{\text {sel. }}=1.1 \times 10^{10} \\
\text { Reac. is not addit. to ring, } \\
\text { but nitroso group }\end{array}$ \\
\hline \multirow[t]{3}{*}{$\begin{array}{l}p \text {-nitroso- } N, N \text {-di- } \\
\text { methylaniline }\end{array}$} & $1.25 \times 10^{10}$ & $22-25$ & 9 & {$[27]$} & $\begin{array}{l}S \text { irrad. using PNDA } \\
\text { bleaching }\end{array}$ & $\begin{array}{l}\text { Rel. to } k_{\mathrm{OH}+\mathrm{C}_{2} \mathrm{H}_{3} \mathrm{OH}}=1.85 \times 10^{9} \\
\text { with ratio }=6.8\end{array}$ \\
\hline & ${ }^{*} 1.8 \times 10^{10}$ & RT & 9 & {$[28]$} & PR of PNDA bleaching & $\begin{array}{l}\text { Absolute. } \mathrm{N}_{2} \mathrm{O} \text { added. Authors } \\
\text { question use of PNDA as } \\
\text { ref. reac. }\end{array}$ \\
\hline & $\dagger^{*} 1.25 \times 10^{10}$ & RT & neut. & {$[29]$} & PR prod. form. & $\begin{array}{l}\text { Absolute. } \mathrm{N}_{2} \mathrm{O} \text { added. No } \mathrm{H} \text { - } \\
\text { corr. Low pulse intensity } \\
\text { recommended }\end{array}$ \\
\hline phenate ion & $9.1 \times 10^{9}$ & $18-25$ & 10.7 & {$[10]$} & $\begin{array}{l}\mathrm{S} \text { irrad. }{ }^{14} \mathrm{CO}_{2} \text { form. from } \\
\text { benzoic acid }\end{array}$ & $\begin{array}{l}\text { Rel. to } k_{\mathrm{OH}+\text { henzoate }}=5.6 \times 10^{9} \\
\text { with ratio }=1.62, e_{\mathrm{aq}}^{-} \text {scav. } \\
\text { by } \mathrm{O}_{2}\end{array}$ \\
\hline
\end{tabular}


TABLE 2. Addition reactions-Continued

\begin{tabular}{|c|c|c|c|c|c|c|}
\hline Reactant & $k\left(M^{-1} \mathrm{~s}^{-1}\right)$ & $T\left({ }^{\circ} \mathrm{C}\right)$ & $\mathrm{pH}$ & Ref. & Method & Comments \\
\hline phenol & $\begin{array}{c}\dagger *(1.4 \pm 0.3) \times 10^{10} \\
8.6 \times 10^{9} \\
6.0 \times 10^{9} \\
\\
1.8 \times 10^{10}\end{array}$ & $\begin{array}{c}19-23 \\
25 \\
18-25\end{array}$ & $\begin{array}{c}7.4-7.7 \\
9\end{array}$ & $\begin{array}{r}{[4]} \\
{[7]} \\
{[10]}\end{array}$ & $\begin{array}{l}\text { PR prod. form. } \\
\\
\mathrm{S} \text { irrad. with PNDA } \\
\mathrm{S} \text { irrad. }{ }^{14} \mathrm{CO}_{2} \text { form. from } \\
\text { benzoic acid } \\
\text { PR comp. with } \mathrm{OH}+\mathrm{CNS}^{-}\end{array}$ & $\begin{array}{l}\text { Absolute. } \mathrm{N}_{2} \mathrm{O} \text { added. No corr. } \\
\text { for } \mathrm{H} \text {-addit. } \\
\text { Rel. to } k_{\mathrm{OH}+\mathrm{PNDA}}=1.25 \times 10^{10} \\
\text { Rel. to } k_{\mathrm{OH}+\text { benzoate }}=5.6 \times 10^{9} \\
\text { with ratio }=1.08, e_{\mathrm{aq}}^{-} \text {scav. } \\
\text { by } \mathrm{O}_{2} \\
\text { Rel. to } k_{\text {thiocyan. }}^{\text {rel. }}=1.1 \times 10^{10} \\
\text { with ratio }=1.6\end{array}$ \\
\hline $\begin{array}{l}\beta \text {-phenylacetate }(2- \\
\text { phenylethanoate) }\end{array}$ & $\begin{array}{l}\dagger^{*}(7.9 \pm 1.1) \times 10^{9} \\
\quad 4.4 \times 10^{9}\end{array}$ & $\begin{array}{r}\text { RT } \\
25\end{array}$ & $\begin{array}{c}6-8 \\
9\end{array}$ & $\begin{array}{l}{[8]} \\
{[7]}\end{array}$ & $\begin{array}{l}\text { PR prod. form. } \\
\text { S irrad. with PNDA }\end{array}$ & $\begin{array}{l}\text { Absolute. } \mathrm{N}_{2} \mathrm{O} \text { added. } \mathrm{H} \text {-corr. } \\
\text { Rel. to } k_{\mathrm{OH}+\mathrm{PNDA}}=1.25 \times 10^{10}\end{array}$ \\
\hline phenylacetate & $5.0 \times 10^{9}$ & 25 & 9 & [7] & S irrad. with PNDA & Rel. to $k_{\mathrm{OH}+\mathrm{PNDA}}=1.25 \times 10^{10}$ \\
\hline phenylhydroxylamine & $\begin{array}{r}\dagger^{*} 1.5 \times 10^{10} \\
2.0 \times 10^{10}\end{array}$ & $\begin{array}{l}\text { RT } \\
\text { RT }\end{array}$ & $3.7-11.5$ & $\begin{array}{l}{[30]} \\
{[30]}\end{array}$ & $\begin{array}{l}\text { PR prod. form. } \\
\text { PR comp. with } \mathrm{OH}+\mathrm{CNS}^{-}\end{array}$ & $\begin{array}{l}\text { Absolute. } \mathrm{N}_{2} \mathrm{O} \text { added. No. H- } \\
\quad \text { corr. } \\
\text { Re.l to } k_{\text {thiocyan. }}^{\text {rel. }}=1.1 \times 10^{10}\end{array}$ \\
\hline pyridine & $\begin{array}{l}(3.1 \pm 0.6) \times 10^{9} \\
* 1.8 \times 10^{9}\end{array}$ & $\begin{array}{r}\text { RT } \\
21\end{array}$ & $\begin{array}{c}\text { neut. } \\
7\end{array}$ & $\begin{array}{l}{[31]} \\
{[33]}\end{array}$ & $\begin{array}{l}\text { PR comp. with } \mathrm{OH}+\mathrm{CNS}^{-} \\
\text {PR prod. form. }\end{array}$ & $\begin{array}{l}\text { Rel. to } k_{\text {thiocyan. }}^{\text {rel. }}=1.1 \times 10^{10} \\
\text { Absolute. } \mathrm{N}_{2} \mathrm{O} \text { added. No H- } \\
\text { corr. }\end{array}$ \\
\hline pyridinium ion & $(3.4 \pm 0.6) \times 10^{7}$ & $\mathrm{RT}$ & 1 & [31] & PR comp. with $\mathrm{OH}+\mathrm{CNS}^{-}$ & Rel. to $k_{\text {thiocyan. }}^{\text {rel. }}=1.1 \times 10^{10}$ \\
\hline $2,2^{\prime}$-dipyridyl & $* 6.2 \times 10^{9}$ & 21 & $\begin{array}{c}9.3 \\
1\end{array}$ & [33] & PR prod. form. & $\begin{array}{l}\text { Absolute. } \mathrm{N}_{2} \mathrm{O} \text { added. No. } \mathrm{H}- \\
\text { corr. }\end{array}$ \\
\hline $4,4^{\prime}$-dipyridyl & $* 5.3 \times 10^{9}$ & 21 & 9.3 & [33] & PR prod. form. & $\begin{array}{l}\text { Absolute. } \mathrm{N}_{2} \mathrm{O} \text { added. } \mathrm{No} \mathrm{H} \text { - } \\
\text { corr. }\end{array}$ \\
\hline salicylate ion & $\begin{array}{c}5.6 \times 10^{9} \\
+* 1.2 \times 10^{10} \\
(2.0 \pm 0.2) \times 10^{10} \\
(9.4 \pm 0.1) \times 10^{9}\end{array}$ & $\begin{array}{r}\mathrm{RT} \\
\mathrm{RT} \\
22-25\end{array}$ & $\begin{array}{l}7 \\
7 \\
9\end{array}$ & $\begin{array}{l}{[32]} \\
{[32]} \\
{[27]}\end{array}$ & $\begin{array}{l}\mathrm{S} \text { irrad. }{ }^{14} \mathrm{CO}_{2} \text { form. from } \\
\text { benzoic acid } \\
\\
\text { PR prod. form. } \\
\text { PR comp. with } \mathrm{OH}+\mathrm{CNS}- \\
\mathrm{S} \text { irrad. with PNDA }\end{array}$ & $\begin{array}{l}\text { Rel. to } k_{\mathrm{OH}+\text { benzoate }}=5.6 \times 10^{9} \\
\quad \text { with ratio }=1.0, e_{\mathrm{all}}^{-} \text {scav. } \\
\text { by } \mathrm{O}_{2} \\
\text { Absolute. } \mathrm{N}_{2} \mathrm{O} \text { added. H-corr. } \\
\text { Rel. to } k_{\text {thiocyan. }}^{\text {rel }}=1.1 \times 10^{10} \\
\text { Rel. to } k_{\mathrm{OH}+\mathrm{PNDA}}=1.25 \times 10^{10}\end{array}$ \\
\hline terephthalate ion & $3.2 \times 10^{9}$ & 25 & 9 & [7] & $S$ irrad. with PNDA & Rel. to $k_{\mathrm{O})+\mathrm{P} \times \mathrm{NDA}}=1.25 \times 10^{10}$ \\
\hline toluene & $*(3.0 \pm 0.7) \times 10^{9}$ & 25 & 3 & {$[12]$} & PR prod. form. & $\begin{array}{l}\text { Absolute. No H-scav. used, } \therefore \\
\text { conc. H-addit }\end{array}$ \\
\hline
\end{tabular}




\section{Chapter V. References}

[1] Dorfman, L. M., Taub, I. A., and Buhler, R. E., J. Chem. Phys. 36, 3051 (1962).

[2] Sauer, M. C., and Ward, B., J. Phys. Chem. 71, 3971 (1967).

[3] Wander, R., Neta, P., and Dorfman, L. M., J. Phys. Chem. 72, 2946 (1968).

[4a] Land, E. J., and Ebert, M., Trans. Faraday Soc. 63, 1181 (1967).

[4b] Adams, G. E., Michael, B. D., and Land, E. J., Nature 211, 293 (1966).

[4c] Adams, G. E., and Michael, B. D., Trans. Faraday Soc. 63, 1171 (1967).

[5] Asmus, K. D., Cercek, B., Ebert, M., Henglein, A., and Wigger, A., Trans. Faraday Soc. 63, 2435 (1967).

[6] Dixon, W. T., and Norman, R. O. C., Proc. Chem. Soc. 97 (1963).

[7] Anbar, M., Meyerstein, D., and Neta, P., J. Phys. Chem. 70, 2660 (1966).

[8] Neta, P., and Dorfman, L. M., Advances in Chemistry Series No. 81, Radiation Chemistry I, 222 (1968).

[9] Hammett, L. P., Physical Organic Chemistry, Chap. 7 (McGraw-Hill Book Co. Inc., New York, N.Y., 1940).

[10] Matthews, R. W., and Sangster, D. F., J. Phys. Chem. 69, 1938 (1965).

[11] Chambers, K. W., Collinson, E., Dainton, F. S., Seddon, W. A., and Wilkinson, F., Trans. Faraday Soc. 63, 1699 (1967).

[12] Dorfman, L. M., Taub, I. A., and Harter, D. A., J. Chem. Phys. 41, 2954 (1964).

[13] Thomas, J. K., Trans. Faraday Soc. 61, 702 (1965).

[14] Adams, G. E., Boag, J. W., Currant, J., and Michael, B. D., Pulse Radiolysis, P. 131, Ed. M. Ebert et al., Academic Press, New York, N.Y. (1965).

[15] Scholes, G., Shaw, P., Willson, R. L., and Ebert, M., Pulse Radiolysis, p. 151, Ed. M. Ebert et al., Academic Press, New York, N.Y. (1965).
[16] Michael, B. D., and Hart, E. J., J. Phys. Chem. 74, 2878 (1970).

[17] Willson, R. L., Greenstock, C. L., Adams, G. E., Wageman, R., and Dorfman, L. M., Int. J. Rad. Phys. and Chem. 3, 211 (1971).

[18] Buxton, G., and Wilmarth, W. K., J. Phys. Chem. 67, 2835 (1963).

[19] Dainton, F. S., and Hardwick, T. J., Trans. Faraday Soc. 53, 333 (1957).

[20] Meissner, G., Henglein, A., and Beck, G., Zeitschrift für Naturforschung, B22, 13 (1967).

[21] Cullis, C. F., Francis, J. M., Raef, Y., and Swallow, A. J., Proc. Roy. Soc. A300, 443 (1967).

[22] Swallow, A. J., Advances in Chemistry Series No. 82 , Radiation Chemistry II, Ed. R. F. Gould, 499 (1968).

[23] Cercek, B., and Ebert, M., Advances in Chemistry Series No. 81, Radiation Chemistry I, 210 (1968).

[24] Asmus, K. D., Henglein, A., and Beck, G., Ber. Bunsengesell. für Phys. Chem., 70, 459 (1966).

[25] Asmus, K. D., and Taub, I. A., J. Phys. Chem. 72, 3382 (1968).

[26] Asmus, K. D., Beck, G., Henglein, A., and Wigger, A., Ber. Bunsengesell. für Phys. Chem. 70, 869 (1966).

[27] Kraljic, I., and Trumbore, C. N., J. Amer. Chem. Soc. 87, 2547 (1965).

[28] Dainton, F. S., and Wiseall, B., Trans. Faraday Soc. 64, 694 (1968).

[29] Baxendale, J. H., and Khan, A. A., Int. J. Rad. Phys. and Chem., 1, 11 (1969).

[30] Wigger, A., Henglein, A., and Asmus, K. D., Ber. Bunsengesell. für Phys. Chem. 71, 513 (1967).

[31] Cercek, B., and Ebert, M., Trans. Faraday Soc. 63, 1687 (1967).

[32] Amphlett, C. B., Adams, G. E., and Michael, B. D., Advances in Chemistry Series No. 81, Radiation Chemistry I, 231, Ed. R. F. Gould (1968).

[33] Simic, M., and Ebert, M., Int. J. Rad. Physics and Chem. 3, 259 (1971).

[34] Chutny, B., and Swallow, A. J., Trans. Faraday Soc. 66, 2847 (1970). 


\section{Chapter VI. Hydrogen Abstraction Reactions}

Fully saturated organic compounds and many unsaturated molecules such as aldehydes and ketones react with hydroxyl radicals by simple hydrogen abstraction to form water and a carbon radical

$$
\mathrm{RH}+\mathrm{OH}=\mathrm{R} \cdot+\mathrm{H}_{2} \mathrm{O}
$$

In some cases, however, the possibility exists that the detailed mechanism of reaction involves, initially, electron abstraction to form a cationic species. which then rapidly deprotonates

$$
\begin{gathered}
\mathrm{RH}+\mathrm{OH}=\mathrm{RH}^{+}+\mathrm{OH}^{-} \\
\mathrm{RH}^{+}=\mathrm{R} \cdot+\mathrm{H}^{+}
\end{gathered}
$$

Since $\mathrm{OH}$ is a strong electrophile, rate constants for hydrogen abstraction are, in general, particularly sensitive to the influence of inductive effects in the structure. In addition to effects on the overall reaction rate, such effects influence the actual site of the hydrogen abstraction process. This is well illustrated by the data for mono- and polyhydric alcohols given in table 3 of this chapter.

For the primary straight chain alcohols, the rate constants increase progressively from $8 \times 10^{8} \mathrm{M}^{-1} \mathrm{~s}^{-1}$ for methanol to about 5-6 $\times 10^{9}$ for alcohols containing five or more carbon atoms. This latter value probably represents a diffusion-controlled limit for reactions of these compounds. The trend undoubtedly illustrates the effect of the inductive effect of the aliphatic carbon chain on the electron density at the $\alpha$-carbon atom, although there is evidence that $\mathrm{OH}$ attack becomes multifocal as the chain length increases $[1,2]$. Information from experiments where $\mathrm{OH}$ is generated either by pulse radiolysis or by photolysis of hydrogen peroxide indicates that the proportion of $\alpha$-carbon attack decreases from 100 percent in methanol to 37 percent in normal butanol. However, as might be expected, chain branching increases the probability of reaction at this position. In isopropanol, about 95 percent of $\mathrm{OH}$ radicals react at the $\alpha$-carbon atom compared with only 66 percent in normal propanol. In the polyhydric alcohols, the effect of carbon chain length on the overall reactivity is less evident.

In the carboxylic acids (tables 4 and 5), the $\mathrm{OH}$ reactivities are generally lower than those for the alcohols. Further, there is a pronounced effect of $\mathrm{pH}$ on the rate constants, the values for the anions being usually greater than those for the unionized structures. It would be expected that resonance stabilization in the carboxyl group would tend to hinder $\mathrm{OH}$ attack at this group and if, therefore, the $\beta$, or more distant, carbon atoms were the only available reaction sites, it is not surprising that the rate constants are lower than those for the corresponding alcohols. Formic acid is an exception since an $\alpha$-hydrogen is available in this molecule and is, therefore, more reactive than acetic acid. Substitution of an $\mathrm{OH}$ group in the $\alpha$-position has a marked effect on reactivity due to the effect on the electron density at this site. Lactic acid is about 20-25 times more reactive than acetic acid. The effect of halide substitution at this position is less, although it is still evident.

Data for carboxylic esters (table 6) are more limited, although where multiple determinations are available, e.g., methyl acetate, the agreement is good. As might be expected the overall reactivities of the esters lie between those of the aliphatic alcohols and acids from which they are derived. It can be seen that trends exist in the data. For a given ester group, the rate constants increase with chain length in the acid stem, e.g. butyrate $>$ propionate $>$ acetate. As has been pointed out [3] ethyl formate is an exception to the trend, although, in this instance, the reactivity is increased considerably by the presence of the $\alpha$-hydrogen atom. For the various acetates, the rate constants also increase with chain length, the value for the $n$-propyl derivative is an order of magnitude greater than that for methyl acetate.

Electrophilic attack by $\mathrm{OH}$ on the carbonyl group is most unlikely in these esters. Although it is difficult to draw definite conclusions as to the site of attack, the apparent effect on the rate constants of the chain lengths of both the acid and the ester stems suggests that both regions of the molecules are reaction sites. This aspect has been discussed in more detail elsewhere [3].

In the ethers (table 7), where the results of several determinations are available, the agreement is generally good. As would be expected, the data for both diethyl ether and dioxan indicate that the $\mathrm{OH}$ reactivities of ethers are generally unaffected by variation in $\mathrm{pH}$.

Rate constants for reactions of $\mathrm{OH}$ with miscellaneous carbonyl compounds are given in table 8 . Understandably, acetone is the ketone for which the most data are available. The agreêment between the values obtained by relative methods using five different reference solutions is clearly excellent, the overall spread between the separate mean values being less than 10 percent. As is the case with the alcohols and esters, the increasing influence of the inductive effect of the alkyl group is again evident in the four simple monoketones. However, the value for acetone seems abnormally low, since the increase from acetone to methylethyl ketone is 
much greater than that observed in the corresponding alcohols. This may be due to the greater influence in acetone of keto-enol tautomerization.

Aldehydes appear to be more reactive, as might be expected, since, in solutions, these compounds have some gem-diol character which should increase the electron availability at the $\alpha$-carbon atom.

The effect of miscellaneous substitutents is indicated in table 9.
Table 10 contains rate data for miscellaneous nitrogen compounds. Information on amino compounds is scarce. However, there has been a systematic study of aliphatic amides [4], which has shown that, in general, these compounds are very reactive. The compound, $\mathrm{CH}_{3} \mathrm{CO} \mathrm{N}\left(\mathrm{CH}_{3}\right) \mathrm{CH}_{2} \mathrm{CH}_{2} \mathrm{~N}\left(\mathrm{CH}_{3}\right) \mathrm{CO}$ $\mathrm{CH}_{3}$ has been isolated from irradiated acetamide solution [4] showing that the principle site of $\mathrm{OH}$ attack on this molecule occurs at an $\mathrm{N}$-methyl group.

TABLE 3. Aliphatic alcohols

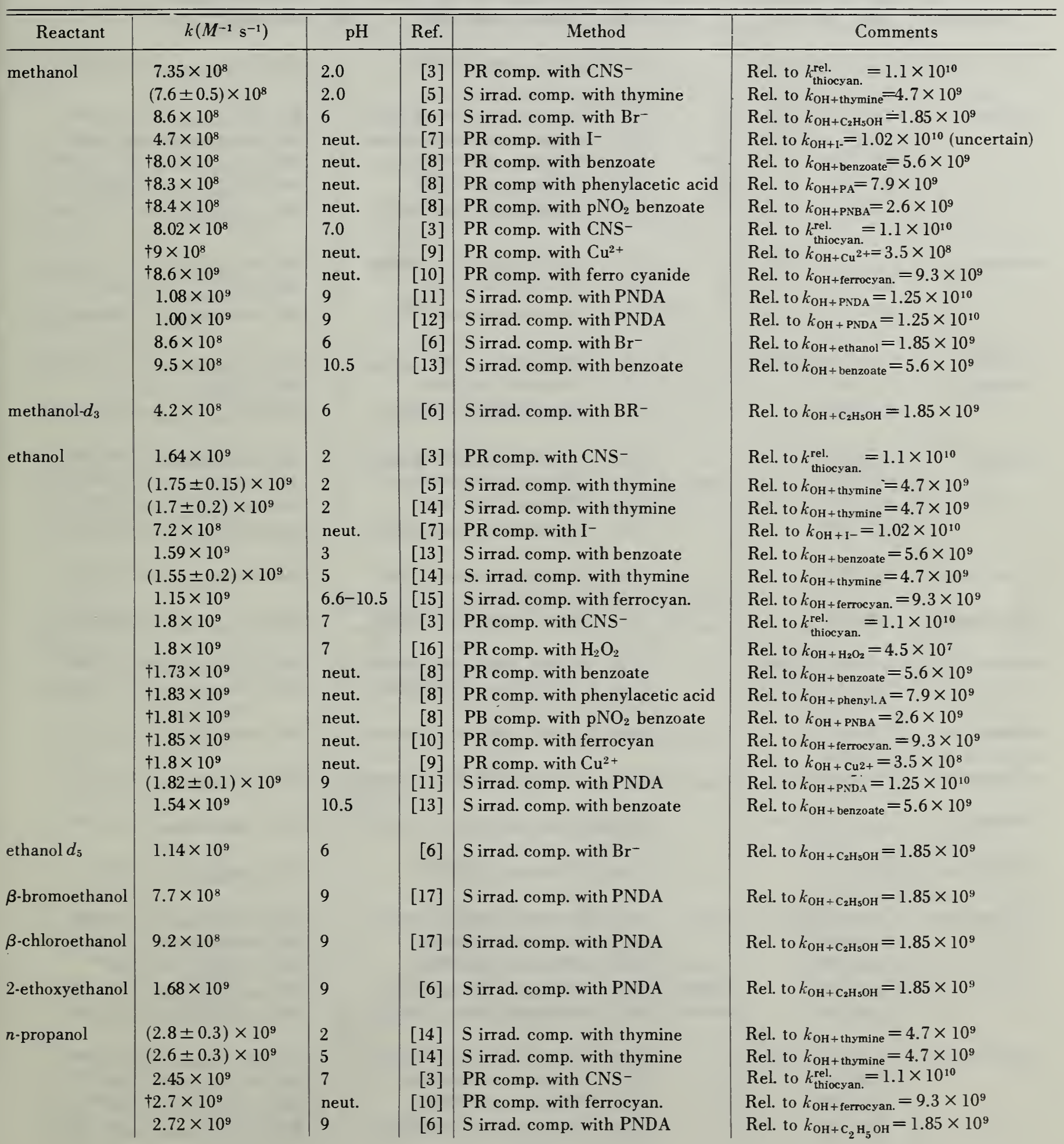


TABLE 3. Aliphatic alcohols-Continued

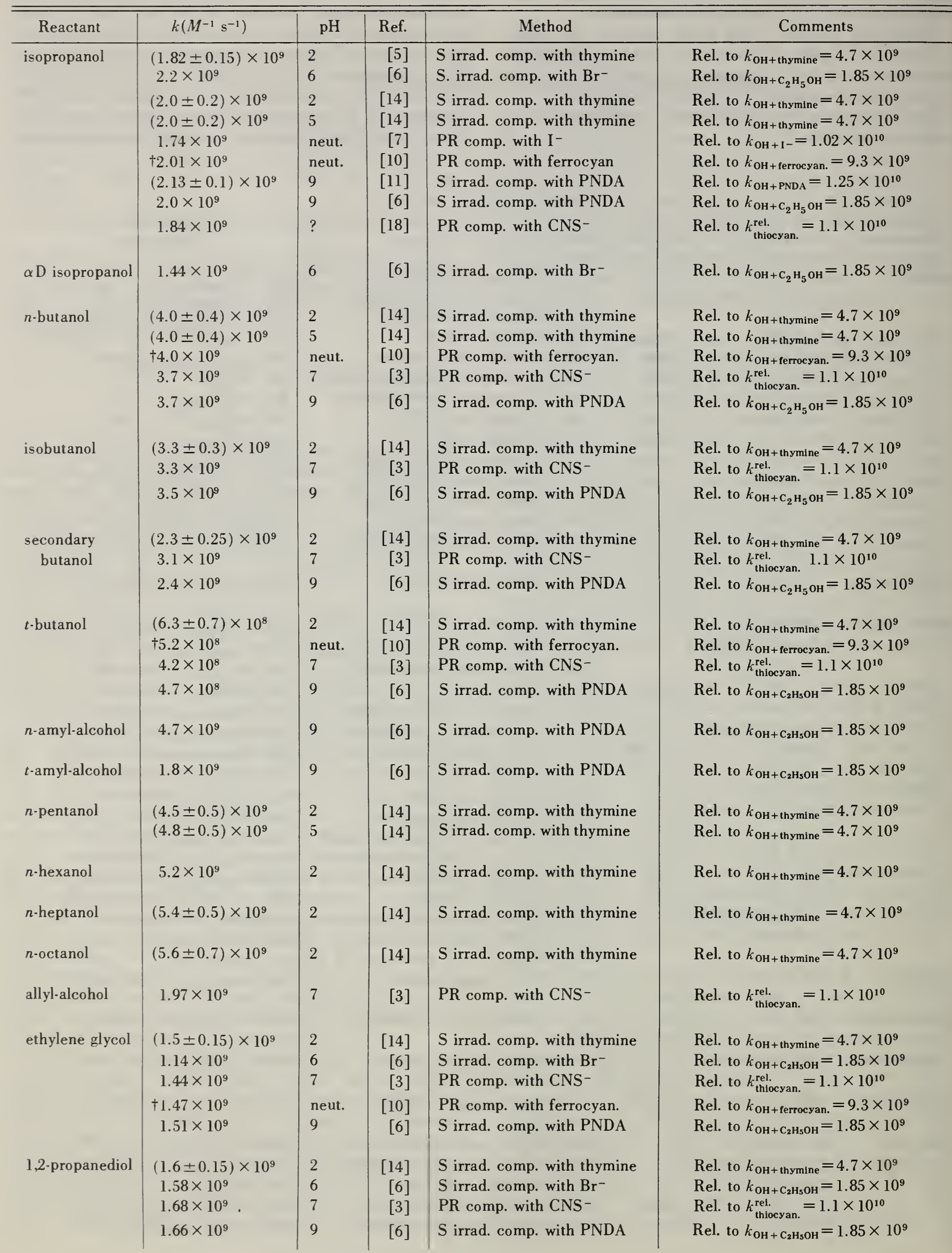


TABLE 3. Aliphatic alcohols-Continued

\begin{tabular}{|c|c|c|c|c|c|}
\hline Reactant & $k\left(\boldsymbol{M}^{-1} \mathrm{~s}^{-1}\right)$ & $\mathrm{pH}$ & Ref. & Method & Comments \\
\hline $1,5-$ propanediol & $\begin{array}{l}2.9 \times 10^{9} \\
2.4 \times 10^{9}\end{array}$ & $\begin{array}{l}6 \\
9\end{array}$ & $\begin{array}{l}{[6]} \\
{[6]}\end{array}$ & $\begin{array}{l}\mathrm{S} \text { irrad. comp. with } \mathrm{Br}^{-} \\
\mathrm{S} \text { irrad. comp. with } \mathrm{PNDA}\end{array}$ & $\begin{array}{l}\text { Rel. to } k_{\mathrm{OH}+\mathrm{C}_{2} \mathrm{H}_{5} \mathrm{OH}}=1.85 \times 10^{9} \\
\text { Rel. to } k_{\mathrm{OH}+\mathrm{C}_{2} \mathrm{H}_{5} \mathrm{OH}}=1.85 \times 10^{9}\end{array}$ \\
\hline $\begin{array}{l}\text { diethylene } \\
\text { glycol }\end{array}$ & $2.0 \times 10^{9}$ & 9 & {$[6]$} & $S$ irrad. comp. with PNDA & Rel. to $k_{\mathrm{OH}+\mathrm{C}_{2} \mathrm{H}_{5} \mathrm{OH}}=1.85 \times 10^{9}$ \\
\hline glycerol & $\begin{array}{l}(1.64 \pm 0.16) \times 10^{9} \\
1.59 \times 10^{9} \\
\dagger 1.9 \times 10^{9} \\
2.04 \times 10^{9} \\
1.85 \times 10^{9}\end{array}$ & $\begin{array}{l}2 \\
7 \\
\text { neut. } \\
9 \\
9\end{array}$ & $\begin{array}{r}{[14]} \\
{[3]} \\
{[10]} \\
{[11]} \\
{[6]}\end{array}$ & $\begin{array}{l}\text { S irrad. comp. with thymine } \\
\text { PR comp. with CNS- } \\
\text { PR comp. with ferrocyan } \\
\text { S irrad. comp. with PNDA } \\
\text { S irrad. comp. with PNDA }\end{array}$ & 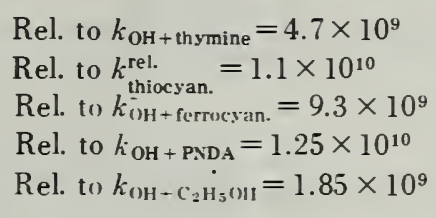 \\
\hline 1,3-butane-diol & $\begin{array}{l}2.2 \times 10^{9} \\
2.3 \times 10^{9}\end{array}$ & $\begin{array}{l}7 \\
9\end{array}$ & $\begin{array}{l}{[3]} \\
{[6]}\end{array}$ & $\begin{array}{l}\text { PR comp. with CNS- } \\
\text { S irrad. comp. witlı PNDA }\end{array}$ & $\begin{array}{l}\text { Rel. to } k_{\text {thiocsan. }}^{\text {rel. }}=1.1 \times 10^{10} \\
\text { Rel. to } k_{()_{H}+\left({ }_{2} \mathrm{H}_{5}() \mathrm{H}\right.}=1.85 \times 10^{9}\end{array}$ \\
\hline 2,3-butane-diol & $1.35 \times 10^{9}$ & 7 & {$[3]$} & PR comp. with CNS- & Rel. to $k_{\text {thiscyan. }}^{\text {rel. }}=1.1 \times 10^{10}$ \\
\hline 1,4-butane-diol & $\begin{array}{l}3.2 \times 10^{9} \\
3.0 \times 10^{9}\end{array}$ & $\begin{array}{l}7 \\
9\end{array}$ & $\begin{array}{l}{[3]} \\
{[6]}\end{array}$ & $\begin{array}{l}\text { PR comp. with } \mathrm{CNS}^{-} \\
\text {S irrad. comp. with PNDA }\end{array}$ & $\begin{array}{l}\text { Rel. } \mathrm{t} \text { ) } k_{\text {thinevan. }}^{\text {rel. }}=1.1 \times 10^{10} \\
\text { Rel. } \mathrm{t} \text { (1) } k_{\left(\mathrm{OH}+\mathrm{C}_{2} \mathrm{H}_{5} \mathrm{OH}\right.}=1.85 \times 10^{9}\end{array}$ \\
\hline erythritol & $2.0 \times 10^{9}$ & 9 & {$[6]$} & S irrad. comp. with PNDA & Rel. $\mathrm{t} 0 k_{\left(\mathrm{OH}-\mathrm{C}_{2} \mathrm{H}_{3}(\mathrm{OH}\right.}=1.85 \times 10^{9}$ \\
\hline pentaerythritol & $3.2 \times 10^{9}$ & 9 & {$[6]$} & S irrad. comp. with PNDA & Rel. $\mathrm{t}\left(\mathrm{)} k_{\left(\mathrm{OH}+\mathrm{C}_{2} \mathrm{H}_{5} \mathrm{OH1}\right.}=1.8 \mathrm{~J} \times 10^{9}\right.$ \\
\hline ribose & $2.1 \times 10^{4}$ & 9 & {$[19]$} & S irrad. comp. with PNDA & Rel. $\mathrm{t} 0 k_{(0 \mathrm{H}+\mathrm{NDA}}=1.25 \times 10^{10}$ \\
\hline D-glucose & $(1.9 \pm 0.15) \times 10^{9}$ & 2 & {$[14]$} & S irrad. comp. with thymine & Rel. $\mathrm{t}\left(k_{() \mathrm{H}+\mathrm{thsmine}}=4.7 \times 10^{9}\right.$ \\
\hline ascorbic acid & $1.2 \times 10^{10}$ & 1 & {$[3]$} & PR comp. with CIS- & Rel. $\mathrm{to} k_{\text {thiscyan. }}^{\mathrm{rel} l .}=1.1 \times 10^{10}$ \\
\hline sucrose & $2.4 \times 10^{9}$ & 2 & {$[14]$} & $\mathrm{S}$ irrad. comp. with thymine & Rel. to $k_{() \mathrm{H}+\text { thrmine }}=4.7 \times 10^{9}$ \\
\hline
\end{tabular}

TABLE 4. Saturated aliphatic acids-(Monobasic)

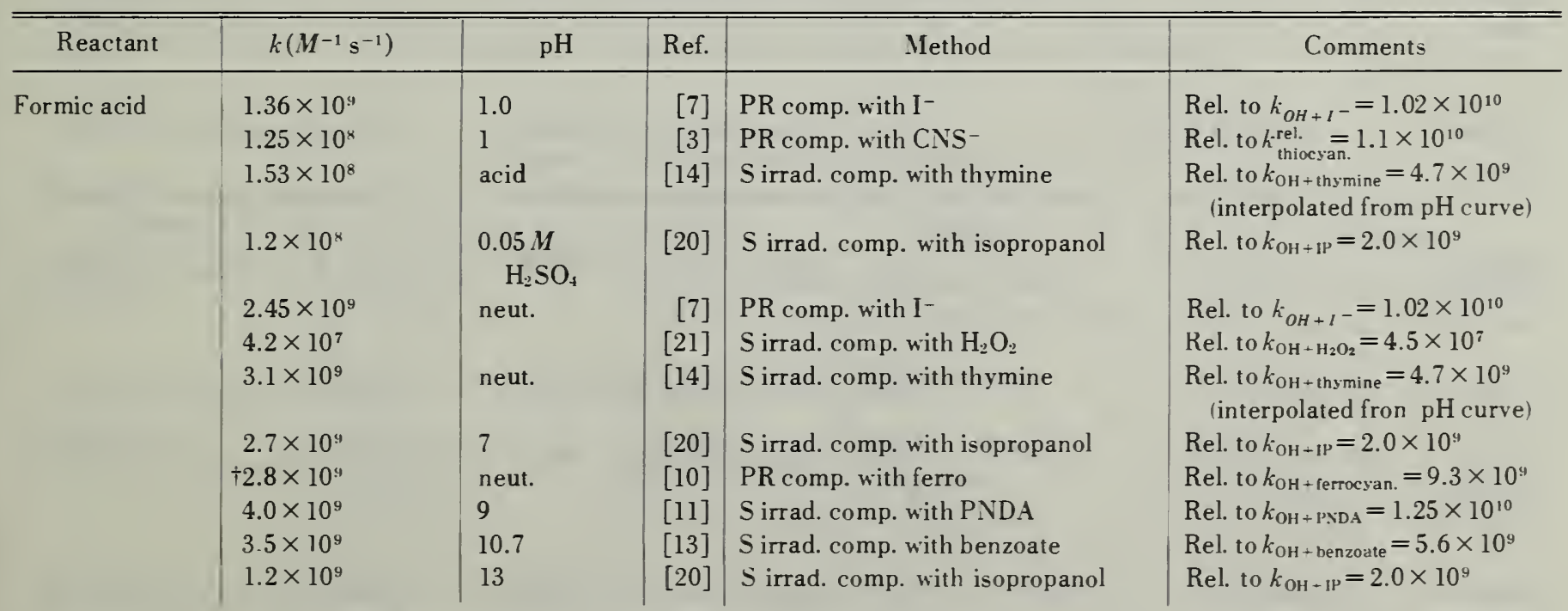


TABLE 4. Saturated aliphatic acids-(Monobasic)-Continued

\begin{tabular}{|c|c|c|c|c|c|}
\hline Reactant & $k\left(M^{-1} \mathrm{~s}^{-1}\right)$ & $\mathrm{pH}$ & Ref. & Method & Comments \\
\hline \multirow[t]{9}{*}{ acetic acid } & $2.3 \times 10^{7}$ & 1.0 & [3] & PR comp. with $\mathrm{CNS}^{-}$ & Rel. to $k_{\text {thiocyan. }}^{\text {rel. }}=1.1 \times 10^{10}$ \\
\hline & $*(9 \pm 0.4) \times 10^{6}$ & 1.0 & {$[7]$} & PR disappearance of $\mathrm{OH}$ spectrum & Absolute \\
\hline & $1.4 \times 10^{7}$ & 1.0 & [7] & PR comp. with $\mathrm{I}^{-}$ & Rel. to $k_{\mathrm{OH}+I^{-}}=1.02 \times 10^{10}$ \\
\hline & $2.0 \times 10^{7}$ & 2 & [14] & $S$ irrad. comp. with thymine & Rel. to $k_{\mathrm{OH}+\text { thymine }}=4.7 \times 10^{9}$ \\
\hline & $+7 \times 10^{7}$ & neut. & {$[10]$} & PR comp. with ferrocyan. & Rel. to $k_{\mathrm{OH}+\text { ferrocyan. }}=9.3 \times 10^{9}$ \\
\hline & $\dagger^{*} 8.5 \times 10^{7}$ & neut. & {$[10]$} & PR prod. form. & $\begin{array}{l}\text { Absolute measurement } \mathrm{N}_{2 .} \mathrm{O} \\
\text { added No corr. for } \mathrm{H} \\
\text { reaction }\end{array}$ \\
\hline & $(8.8 \pm 0.5) \times 10^{7}$ & 9 & {$[11]$} & S irrad. comp. with PNDA & Rel. to $K_{O H}+P . N D .4=1.25 \times 10^{10}$ \\
\hline & $7.2 \times 10^{7}$ & 9 & [6] & S irrad. comp. with PNDA & Rel. to $k_{\mathrm{OH}+\mathrm{C}_{2} \mathrm{H}_{5} \mathrm{OH}}=1.85 \times 10^{\prime \prime}$ \\
\hline & $6.2 \times 10^{7}$ & 10.7 & {$[13]$} & $S$ irrad. comp. with benzoate & Rel. to $k_{\mathrm{OH}+\text { benzoate }}=5.6 \times 10^{9}$ \\
\hline $\begin{array}{l}\text { bromoacetic } \\
\text { acid }\end{array}$ & $4.4 \times 10^{7}$ & 9 & {$[6]$} & S irrad. comp. with PNDA & Rel. to $k_{\mathrm{OH}}+\mathrm{C}_{2} \mathrm{H}_{5} \mathrm{OH}=1.85 \times 10^{\prime \prime}$ \\
\hline \multirow{3}{*}{$\begin{array}{l}\text { chloracetic } \\
\text { acid }\end{array}$} & $4.3 \times 10^{7}$ & 1 & {$[3]$} & PR comp. with $\mathrm{CNS}^{-}$ & Rel. to $k_{\text {thiocyan. }}^{\text {rel. }}=1.1 \times 10^{10}$ \\
\hline & $(7.0 \pm 0.7) \times 10^{7}$ & 2 & [14] & $\mathrm{S}$ irrad. comp. with thymine & Rel. to $k_{\mathrm{OH}+\text { thymine }}=4.7 \times 10^{\prime \prime}$ \\
\hline & $5.5 \times 10^{7}$ & 9 & {$[6]$} & S irrad. comp. with PNDA & Rel. to $k_{\mathrm{OH}+\mathrm{C}_{2} \mathrm{H}_{5} \mathrm{OH}}=1.85 \times 10^{4}$ \\
\hline $\begin{array}{l}\text { fluor-acetic } \\
\text { acid }\end{array}$ & $3.0 \times 10^{7}$ & 9 & {$[6]$} & $S$ irrad. comp. with PNDA & Rel. to $k_{\mathrm{OH}+\mathrm{C}_{2} \mathrm{H}_{5} \mathrm{OH}}=1.85 \times 10^{\prime \prime}$ \\
\hline $\begin{array}{l}\text { methoxy-acetic } \\
\text { acid }\end{array}$ & $6.0 \times 10^{8}$ & 9 & {$[6]$} & $S$ irrad. comp. with PNDA & Rel. to $k_{\mathrm{OH}+\mathrm{C}_{2} \mathrm{H}_{5} \mathrm{OH}}=1.85 \times 10^{9}$ \\
\hline $\begin{array}{l}\text { cyano-acetic } \\
\text { acid }\end{array}$ & $1.54 \times 10^{7}$ & 9 & {$[6]$} & $S$ irrad. comp. with PNDA & Rel. to $k_{\mathrm{OH}+\mathrm{C}_{2} \mathrm{H}_{5} \mathrm{OH}}=1.85 \times 10^{9}$ \\
\hline $\begin{array}{l}\text { ethylene- } \\
\text { diamine } \\
\text { tetracetic } \\
\text { acid }\end{array}$ & $3.5 \times 10^{9}$ & 9 & {$[19]$} & S irrad. comp. with PNDA & Rel. to $k_{\mathrm{OH}+\mathrm{PNDA}}=1.25 \times 10^{10}$ \\
\hline $\begin{array}{l}\text { trimethyl } \\
\text { acetic } \\
\text { acid }\end{array}$ & $1.4 \times 10^{9}$ & 9 & {$[6]$} & $S$ irrad. comp. with PNDA & Rel. to $k_{\mathrm{OH}+\mathrm{C}_{2} \mathrm{H} \mathrm{OH}}=1.85 \times 10^{10}$ \\
\hline \multirow[t]{2}{*}{$\begin{array}{l}\text { propionic } \\
\text { acid }\end{array}$} & $(4.6 \pm 0.5) \times 10^{8}$ & 2 & {$[14]$} & $\mathrm{S}$ irrad. comp. with thymine & Rel. to $k_{\mathrm{OH}+\text { thymine }}=4.7 \times 10^{9}$ \\
\hline & $7.9 \times 10^{8}$ & 9 & {$[6]$} & $S$ irrad. comp. with PNDA & Rel. to $k_{\mathrm{OH}+\mathrm{C}_{2} \mathrm{H}_{5} \mathrm{OH}}=1.85 \times 10^{9}$ \\
\hline $\begin{array}{l}\alpha \text {-bromo- } \\
\text { propionic } \\
\quad \text { acid }\end{array}$ & $2.2 \times 10^{x}$ & 8.5 & {$[17]$} & $S$ irrad. comp. with PNDA & Rel. to $k_{\mathrm{OH}+\mathrm{C}_{2} \mathrm{H}_{\mathrm{S}} \mathrm{OH}}=1.85 \times 10^{9}$ \\
\hline pyruvic acid & $3.2 \times 10^{7}$ & 9 & {$[19]$} & $S$ irrad. comp. with PNDA & Rel. to $k_{\mathrm{OH}+\mathrm{PNDA}}=1.25 \times 10^{10}$ \\
\hline $\begin{array}{l}\beta \text {-bromo } \\
\text { propionic } \\
\text { acid }\end{array}$ & $2.3 \times 10^{8}$ & 8.5 & {$[17]$} & $S$ irrad. comp. with PNDA & Rel. to $k_{\mathrm{OH}+\mathrm{C}_{2} \mathrm{H}_{3} \mathrm{OH}}=1.85 \times 10^{9}$ \\
\hline $\begin{array}{l}\alpha \text {-chloro- } \\
\text { propionic } \\
\text { acid }\end{array}$ & $2.4 \times 10^{8}$ & 8.5 & {$[17]$} & $S$ irrad. comp. with PNDA & Rel. to $k_{\mathrm{OH}+\mathrm{C}_{2} \mathrm{H}_{5} \mathrm{OH}}=1.85 \times 10^{9}$ \\
\hline $\begin{array}{l}\beta \text {-chloro- } \\
\text { propionic } \\
\text { acid }\end{array}$ & $3.2 \times 10^{8}$ & 8.5 & {$[17]$} & S irrad. comp. with PNDA & Rel. to $k_{\mathrm{OH}+\mathrm{C}_{2} \mathrm{H}_{5} \mathrm{OH}}=1.85 \times 10^{9}$ \\
\hline
\end{tabular}


TABlE 4. Saturated aliphatic acids-(Monobasic)-Continued

\begin{tabular}{|c|c|c|c|c|c|}
\hline Reactant & $k\left(M^{-1} \mathrm{~s}^{-1}\right)$ & $\mathrm{pH}$ & Ref. & Method & Comments \\
\hline$n$-butyric acid & $\begin{array}{l}(1.64 \pm 0.2) \times 10^{9} \\
1.85 \times 10^{9}\end{array}$ & $\begin{array}{l}2 \\
9\end{array}$ & $\begin{array}{r}{[14]} \\
{[6]}\end{array}$ & $\begin{array}{l}\mathrm{S} \text { irrad. comp. with thymine } \\
\mathrm{S} \text { irrad. comp. with PNDA }\end{array}$ & $\begin{array}{l}\text { Rel. to } k_{\mathrm{OH}+\text { thymine }}=4.7 \times 10^{9} \\
\text { Rel. to } k_{\mathrm{OH}+\mathrm{C}_{2} \mathrm{H}_{3} \mathrm{OH}}=1.85 \times 10^{9}\end{array}$ \\
\hline iso butyric acid & $1.26 \times 10^{9}$ & 9 & [6] & $S$ irrad. comp. with PNDA & Rel. to $k_{\mathrm{OH}+\mathrm{C}_{2} \mathrm{H}_{5} \mathrm{OH}}=1.85 \times 10^{9}$ \\
\hline $\begin{array}{l}\text { cyclobutane } \\
\text { carboxylic } \\
\text { acid }\end{array}$ & $3.02 \times 10^{9}$ & 9 & [6] & $S$ irrad. comp. with PNDA & Rel. to $k_{\mathrm{OH}+\mathrm{C}_{2} \mathrm{H} \mathrm{OH}}=1.85 \times 10^{9}$ \\
\hline $\begin{array}{l}\alpha \text {-amino- } n \text { - } \\
\text { butyric acid }\end{array}$ & $(3.3 \pm 0.3) \times 10^{8}$ & 2 & {$[14]$} & S irrad. comp. with thymine & Rel. to $k_{\mathrm{OH}+\text { thymine }}=4.7 \times 10^{9}$ \\
\hline $\begin{array}{l}\beta \text {-amino- } n \text { - } \\
\text { butyric acid }\end{array}$ & $(6.8 \pm 0.7) \times 10^{7}$ & 2 & {$[14]$} & S irrad. comp. with thymine & Rel. to $k_{\mathrm{OH}+\text { thymine }}=4.7 \times 10^{9}$ \\
\hline $\begin{array}{l}\gamma \text {-amino- } n \text { - } \\
\text { butyric acid }\end{array}$ & $(1.9 \pm 0.2) \times 10^{8}$ & 2 & {$[14]$} & S irrad. comp. with thymine & Rel. to $k_{\mathrm{OH}+\text { thymine }}=4.7 \times 10^{9}$ \\
\hline $\begin{array}{l}\text { 2-methyl } \\
\text { butyric acid }\end{array}$ & $2.4 \times 10^{9}$ & 9 & [6] & S irrad. comp. with PNDA & Rel. to $k_{\mathrm{OH}+\mathrm{C}_{2} \mathrm{H}_{\mathrm{SOH}}}=1.85 \times 10^{9}$ \\
\hline $\begin{array}{l}\text { 3-methyl } \\
\text { butyric acid }\end{array}$ & $2.2 \times 10^{9}$ & 9 & {$[6]$} & $S$ irrad. comp. with PNDA & Rel. to $k_{\mathrm{OH}+\mathrm{C}_{2} \mathrm{H}_{\mathrm{S}} \mathrm{OH}}=1.85 \times 10^{9}$ \\
\hline $\begin{array}{l}\text { 3,3-dimethyl } \\
\text { butyric acid }\end{array}$ & $1.66 \times 10^{9}$ & 9 & {$[6]$} & S irrad. comp. with PNDA & Rel. to $k_{\mathrm{OH}+\mathrm{C}_{2} \mathrm{H}_{\mathrm{O}} \mathrm{OH}}=1.85 \times 10^{9}$ \\
\hline$n$-valeric acid & $2.9 \times 10^{9}$ & 9 & {$[6]$} & S irrad. comp. with PNDA & Rel. to $k_{\mathrm{OH}+\mathrm{C}_{2} \mathrm{H}_{\mathrm{O}} \mathrm{OH}}=1.85 \times 10^{9}$ \\
\hline$n$-caproic acid & $3.9 \times 10^{9}$ & 9 & [6] & $S$ irrad. comp. with PNDA & Rel. to $k_{\mathrm{OH}+\mathrm{C}_{2} \mathrm{H}_{5} \mathrm{OH}}=1.85 \times 10^{9}$ \\
\hline $\begin{array}{l}\text { cyclo-pentane } \\
\text { carboxylic } \\
\text { acid }\end{array}$ & $4.0 \times 10^{9}$ & 9 & {$[6]$} & S irrad. comp. with PNDA & Rel. to $k_{\mathrm{OH}+\mathrm{C}_{2} \mathrm{H}_{\mathrm{S}} \mathrm{OH}}=1.85 \times 10^{9}$ \\
\hline $\begin{array}{l}\text { cyclo-hexane } \\
\text { carboxylic } \\
\text { acid }\end{array}$ & $5.4 \times 10^{9}$ & 9 & {$[6]$} & S irrad. comp. with PNDA & Rel. to $k_{\mathrm{OH}+\mathrm{C}_{2} \mathrm{H}_{5} \mathrm{OH}}=1.85 \times 10^{9}$ \\
\hline
\end{tabular}

TABLE 5. Polybasic and hydroxy-carboxylic acids

\begin{tabular}{|c|c|c|c|c|c|}
\hline Reactant & $k\left(M^{-1} \mathrm{~s}^{-1}\right)$ & $\mathrm{pH}$ & Ref. & Method & Comments \\
\hline \multirow[t]{3}{*}{ oxalic acid } & $(8 \pm 3) \times 10^{6}$ & 2 & {$[14]$} & $S$ irrad. comp. with thymine & Rel. to $k_{\mathrm{OH}+\text { thymine }}=4.7 \times 10^{9}$ \\
\hline & $1.03 \times 10^{7}$ & 7 & {$[22]$} & $\begin{array}{l}S \text { irrad. comp. with methanol and } \\
\text { ethanol }\end{array}$ & Rel. to $k_{\mathrm{OH}+\mathrm{C}_{2} \mathrm{H}_{5} \mathrm{OH}}=1.85 \times 10^{9}$ \\
\hline & $(8.4 \pm 1.5) \times 10^{6}$ & 9 & {$[11]$} & S irrad. comp. with PNDA & Rel. to $k_{\mathrm{OH}+\mathrm{PNDA}}=1.25 \times 10^{111}$ \\
\hline \multirow[t]{3}{*}{ malonic acid } & $(1.7 \pm 0.15) \times 10^{7}$ & 2 & {$[14]$} & S irrad. comp. with thymine & Rel. to $k_{\mathrm{OH}+\text { thymine }}=4.7 \times 10^{9}$ \\
\hline & $3.0 \times 10^{8}$ & $6-7$ & {$[3]$} & PR comp. with CNS ${ }^{-}$ & Rel. to $k_{\text {thlocyan. }}^{\mathrm{rel}}=1.1 \times 10^{10}$ \\
\hline & $5.5 \times 10^{7}$ & 9 & {$[6]$} & S irrad. comp. with PNDA & Rel. to $k_{\mathrm{OH}+\mathrm{PNDA}}=1.25 \times 10^{10}$ \\
\hline succinic acid & $(1.2 \pm 0.1) \times 10^{8}$ & 2 & {$[14]$} & S irrad. comp. with thymine & Rel. to $k_{\mathrm{OH}+\text { thymine }}=4.7 \times 10^{9}$ \\
\hline glutaric acid & $(6.1 \pm 0.5) \times 10^{8}$ & 2 & {$[14]$} & S. irrad. comp. with thymine & Rel. to $k_{\mathrm{OH}+\text { thymine }}=4.7 \times 10^{9}$ \\
\hline adipic acid & $(1.5 \pm 0.15) \times 10^{9}$ & 2 & {$[14]$} & S irrad. comp. with thymine & Rel. to $k_{\mathrm{OH}+\text { thymine }}=4.7 \times 10^{9}$ \\
\hline
\end{tabular}


TABLE 5. Polybasic and hydroxy-carboxylic acids-Continued

\begin{tabular}{|c|c|c|c|c|c|}
\hline Reactant & $k\left(M^{-1} \mathrm{~s}^{-1}\right)$ & $\mathrm{pH}$ & Ref. & Method & Comments \\
\hline pimelic acid & $(2.6 \pm 0.3) \times 10^{9}$ & 2 & {$[14]$} & S irrad. comp. with thymine & Rel. to $k_{\mathrm{OH}+\text { thymine }}=4.7 \times 10^{9}$ \\
\hline suberic acid & $(3.5 \pm 0.4) \times 10^{9}$ & 2 & {$[14]$} & S irrad. comp. with thymine & Rel. to $k_{\mathrm{OH}+\text { thymine }}=4.7 \times 10^{9}$ \\
\hline azelaic acid & $(4.0 \pm 0.5) \times 10^{9}$ & 2 & {$[14]$} & S irrad. comp. with thymine & Rel. to $k_{\mathrm{OH}+\text { thymine }}=4.7 \times 10^{4}$ \\
\hline sebacic acid & $(4.7 \pm 0.5) \times 10^{9}$ & 2 & [14」 & S irrad. comp. with thymine & Rel. to $k_{\mathrm{OH}+\text { thymine }}=4.7 \times 10^{9}$ \\
\hline citric acid & $\begin{array}{l}5 \times 10^{7} \\
(4.7 \pm 0.3) \times 10^{8}\end{array}$ & $\begin{array}{l}1 \\
2\end{array}$ & $\begin{array}{r}{[3]} \\
{[14]}\end{array}$ & $\begin{array}{l}\text { PR comp. with } \mathrm{CNS}^{-} \\
\mathrm{S} \text { irrad, comp. with thymine }\end{array}$ & $\begin{array}{l}\text { Rel. to } k_{\text {thiocyan. }}^{\text {rel. }}=1.1 \times 10^{10} \\
\text { Rel. to } k_{\mathrm{OH}+\text { thymine }}=4.7 \times 10^{9}\end{array}$ \\
\hline glycolic acid & $\begin{array}{l}(4 \pm 0.3) \times 10^{8} \\
7.2 \times 10^{8}\end{array}$ & $\begin{array}{l}9 \\
9\end{array}$ & $\begin{array}{l}{[6]} \\
{[6]}\end{array}$ & $\begin{array}{l}\text { S irrad. comp. with PNDA } \\
\text { S irrad. comp. with PNDA }\end{array}$ & $\begin{array}{l}\text { Rel. to } k_{\mathrm{OH}+\mathrm{C}_{2} \mathrm{H}_{5} \mathrm{OH}}=1.85 \times 10^{9} \\
\text { Rel. to } k_{\mathrm{OH}+\mathrm{C}_{2} \mathrm{H}_{5} \mathrm{OH}}=1.85 \times 10^{9}\end{array}$ \\
\hline lactic acid & $\begin{array}{l}4.3 \times 10^{8} \\
(5.6 \pm 0.5) \times 10^{8}\end{array}$ & $\begin{array}{l}1 \\
2\end{array}$ & $\begin{array}{l}:[3] \\
{[14]}\end{array}$ & $\begin{array}{l}\text { PR comp. with } \mathrm{CNS}^{-} \\
\mathrm{S} \text { irrad. comp. with thymine }\end{array}$ & $\begin{array}{l}\text { Rel. to } k_{\text {thiocyan. }}^{\text {rel. }}=1.1 \times 10^{10} \\
\text { Rel. to } k_{\mathrm{OH}+\text { thynine }}=4.7 \times 10^{9}\end{array}$ \\
\hline malic acid & $(4.7 \pm 0.5) \times 10^{8}$ & 2 & {$[14]$} & $S$ irrad. comp. with thymine & Rel. to $k_{\mathrm{OH}+\text { thymine }}=4.7 \times 10^{4}$ \\
\hline tartaric acid & $\begin{array}{l}(5.2 \pm 0.5) \times 10^{8} \\
6.8 \times 10^{8}\end{array}$ & $\begin{array}{l}2 \\
9\end{array}$ & $\begin{array}{l}{[14]} \\
{[19]}\end{array}$ & $\begin{array}{l}S \text { irrad. comp. with thymine } \\
S \text { irrad. comp. with PNDA }\end{array}$ & $\begin{array}{l}\text { Rel. to } k_{\mathrm{OH}+\text { thymine }}=4.7 \times 10^{9} \\
\text { Rel. to } k_{\mathrm{OH}+\mathrm{PNDA}}=1.25 \times 10^{10}\end{array}$ \\
\hline $\begin{array}{l}\text { tetrahydroxy- } \\
\text { succinic acid }\end{array}$ & $1.3 \times 10^{9}$ & 9 & [6] & S irrad. comp. with PNDA & Rel. to $k_{\mathrm{OH}+\mathrm{C}_{2} \mathrm{H}_{5} \mathrm{OH}}=1.85 \times 10^{9}$ \\
\hline thioglycolic acid & $6.0 \times 10^{9}$ & 1 & {$[3]$} & PR comp. with $\mathrm{CNS}^{-}$ & Rel. to $k_{\text {thiocyan. }}^{\text {rel. }}=1.1 \times 10^{10}$ \\
\hline
\end{tabular}

TABLE 6. Aliphatic carboxylic esters

\begin{tabular}{|c|c|c|c|c|c|}
\hline Reactant & $k\left(M^{-1} \mathrm{~s}^{-1}\right)$ & $\mathrm{pH}$ & Ref. & Method & Comments \\
\hline ethyl formate & $3.8 \times 10^{8}$ & $6-7$ & {$[3]$} & PR comp. with CNS- & Rel. to $k_{\text {thiocyan. }}^{\text {rel. }}=1.1 \times 10^{10}$ \\
\hline \multirow[t]{3}{*}{ methyl acetate } & $1.3 \times 10^{8}$ & 2 & {$[3]$} & PR comp. with $\mathrm{CNS}^{-}$ & Rel. to $k_{\text {thiocyan. }}^{\text {rel. }}=1.1 \times 10^{10}$ \\
\hline & $1.2 \times 10^{8}$ & $6-7$ & {$[3]$} & PR comp. with CNS- & Rel. to $k_{\text {thiocyan. }}^{\text {rel. }}=1.1 \times 10^{10}$ \\
\hline & $1.1 \times 10^{8}$ & 9 & {$[6]$} & S irrad. comp. with PNDA & Rel. to $k_{\mathrm{OH}+\mathrm{C}_{2} \mathrm{HsOH}}=1.85 \times 10^{9}$ \\
\hline \multirow[t]{2}{*}{ ethyl acetate } & $(2.4 \pm 0.2) \times 10^{8}$ & 2 & {$[14]$} & $\mathrm{S}$ irrad. comp. with thymine & Rel. to $k_{\mathrm{OH}+\text { thymine }}=4.7 \times 10^{9}$ \\
\hline & $4.0 \times 10^{8}$ & $6-7$ & {$[3]$} & PR comp. with $\mathrm{CNS}^{-}$ & Rel. to $k_{\text {thiocyan. }}^{\mathrm{rel}}=1.1 \times 10^{10}$ \\
\hline \multirow[t]{2}{*}{ isopropyl acetate } & $4.3 \times 10^{8}$ & 2 & [3] & PR comp. with $\mathrm{CNS}^{-}$ & Rel. to $k_{\text {thiocyan. }}^{\text {rel. }}=1.1 \times 10^{10}$ \\
\hline & $4.5 \times 10^{\mathrm{s}}$ & $6-7$ & {$[3]$} & PR comp. with $\mathrm{CNS}^{-}$ & Rel. to $k_{\text {thiocyan. }}^{\text {rel. }}=1.1 \times 10^{10}$ \\
\hline$n$-propyl acetate & $1.4 \times 10^{9}$ & $6-7$ & {$[3]$} & PR comp. with CNS- & Rel. to $k_{\text {thiocyan. }}^{\text {rel. }}=1.1 \times 10^{10}$ \\
\hline methyl propionate & $4.5 \times 10^{8}$ & $6-7$ & {$[3]$} & PR comp. with $\mathrm{CNS}^{-}$ & Rel. to $k_{\text {thiocyan. }}^{\text {rel. }}=1.1 \times 10^{10}$ \\
\hline ethyl propionate & $8.7 \times 10^{8}$ & $6-7$ & {$[3]$} & PR comp. with $\mathrm{CNS}^{-}$ & Rel. to $k_{\text {thiocyan. }}^{\text {rel. }}=1.1 \times 10^{10}$ \\
\hline methyl butyrate & $1.7 \times 10^{9}$ & $6-7$ & {$[3]$} & PR comp. with CNS- & Rel. to $k_{\text {thiocyan. }}^{\text {rel. }}=1.1 \times 10^{10}$ \\
\hline ethyl butyrate & $1.6 \times 10^{9}$ & $6-7$ & {$[3]$} & PR comp. with $\mathrm{CNS}^{-}$ & Rel. to $k_{\text {thiocyan. }}^{\text {rel. }}=1.1 \times 10^{10}$ \\
\hline diethyl malonate & $6.5 \times 10^{8}$ & $6-7$ & {$[3]$} & PR comp. with CNS- & Rel. to $k_{\text {thiocyan. }}^{\text {rel. }}=1.1 \times 10^{10}$ \\
\hline diethyl succinate & $7.8 \times 10^{x}$ & $6-7$ & {$[3]$} & PR comp. with $\mathrm{CNS}^{-}$ & Rel. to $k_{\text {thiocyan. }}^{\text {rel. }}=1.1 \times 10^{10}$ \\
\hline
\end{tabular}


TABLE 7. Ethers

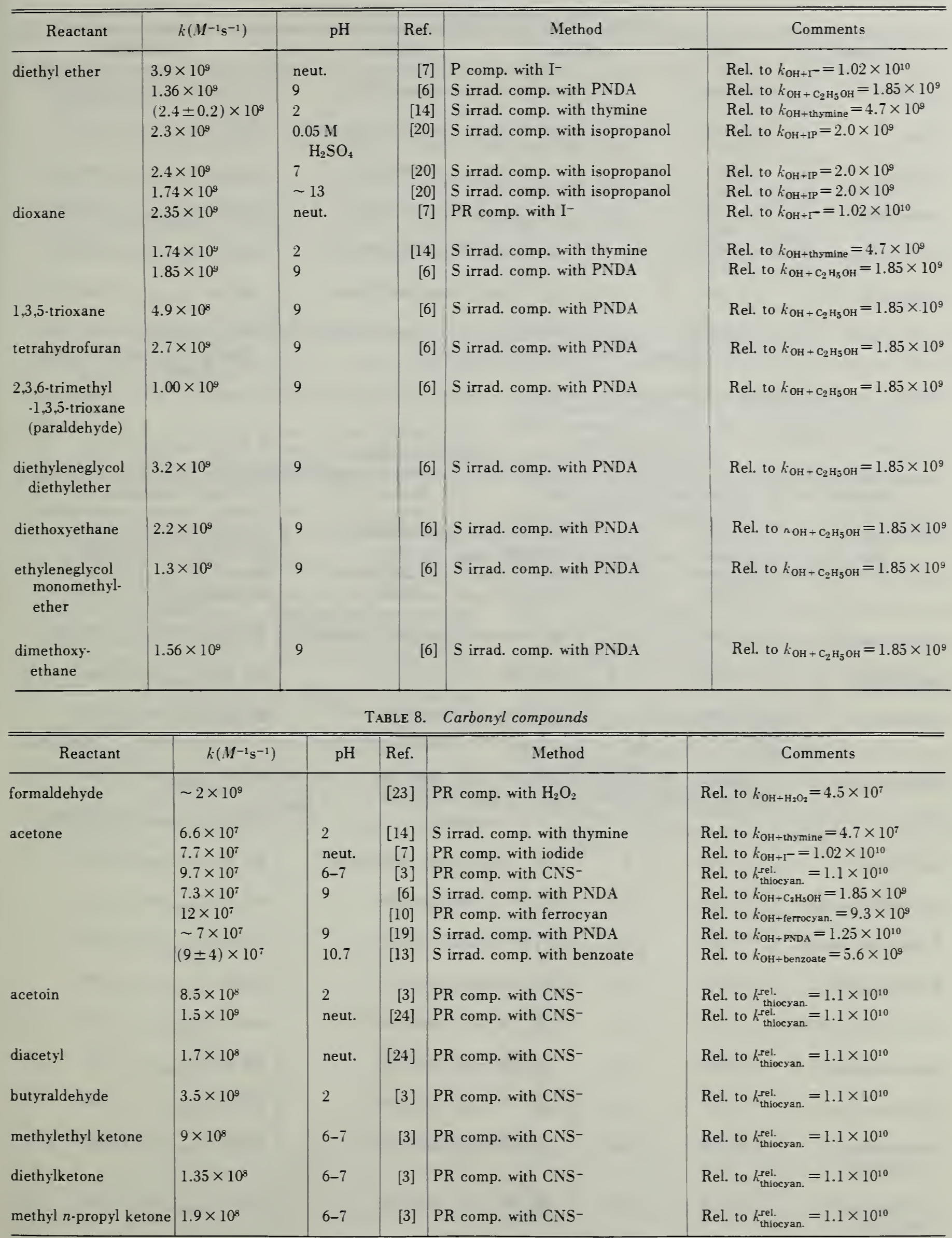


TABLE 9. Substituted hydrocarbons

\begin{tabular}{|c|c|c|c|c|c|}
\hline Reactant & $k\left(M^{-1} \mathrm{~s}^{-1}\right)$ & $\mathrm{pH}$ & Ref. & Method & Comments \\
\hline methane & $2.4 \times 10^{8}$ & 9 & {$[6]$} & S irrad. comp. with PNDA & Rel. to $k_{\mathrm{OH}}+\mathrm{c}_{2} \mathrm{H}_{5} \mathrm{OH}=1.85 \times 10^{9}$ \\
\hline ethane & $1.2 \times 10^{9}$ & 1.2 & {$[25]$} & $S$ irrad. comp. with formic acid & Rel. to $k_{\mathrm{OH}+\mathrm{H} \mathrm{COOH}}=1.2 \times 10^{*}$ \\
\hline chloroform & $1.4 \times 10^{7}$ & 9 & {$[6]$} & S irrad. comp. with PNDA & Rel. to $k_{\mathrm{OH}}+\mathrm{c}_{2} \mathrm{H}_{5} \mathrm{OH}=1.85 \times 10^{9}$ \\
\hline cyanomethane & $3.5 \times 10^{6}$ & 9 & {$[6]$} & S irrad. comp. with PNDA & Rel. to $k_{\mathrm{OH}+\mathrm{C}_{2} \mathrm{H}_{5} \mathrm{OH}}=1.85 \times 10^{9}$ \\
\hline diethoxyethane & $1.55 \times 10^{9}$ & 9 & {$[6]$} & $S$ irrad. comp. $w$ th PNDA & Rel. to $k_{\mathrm{OH}+\mathrm{C}_{2} \mathrm{H}_{5} \mathrm{OH}}=1.85 \times 10^{9}$ \\
\hline dimethoxyethane & $5.7 \times 10^{8}$ & 9 & [6] & S irrad. comp. with PNDA & Rel. to $k_{\mathrm{OH}+\mathrm{C}_{2} \mathrm{H}_{5} \mathrm{OH}}=1.85 \times 10^{9}$ \\
\hline nitromethane & $\begin{array}{c}3.1 \times 10^{8} \\
\dagger^{*}(8.5 \pm 1.5) \times 10^{9}\end{array}$ & $\begin{array}{c}9 \\
10.5\end{array}$ & $\begin{array}{r}{[6]} \\
{[26]}\end{array}$ & $\begin{array}{l}S \text { irrad. comp. with PNDA } \\
\text { PR prod. form. }\end{array}$ & $\begin{array}{l}\text { Rel. to } k_{\mathrm{OH}}+\mathrm{C}_{2} \mathrm{H}_{5} \mathrm{OH}=1.85 \times 10^{9} \\
\text { Absolute } \mathrm{N}_{2} \mathrm{O} \text { added. no correct. } \\
\text { for } \mathrm{H} \text { addit. }\end{array}$ \\
\hline
\end{tabular}

TABLE 10. Nitrogen compounds

\begin{tabular}{|c|c|c|c|c|c|}
\hline Reactant & $k\left(M^{-1} \mathrm{~s}^{-1}\right)$ & $\mathrm{pH}$ & Ref. & Method & Comments \\
\hline methylamine & $\begin{array}{l}1.9 \times 10^{7} \\
1.8 \times 10^{8} \\
2.4 \times 10^{9} \\
1.15 \times 10^{10}\end{array}$ & $\begin{array}{l}5 \\
\text { neut. } \\
12 \\
12\end{array}$ & $\begin{array}{r}{[69]} \\
{[27]} \\
{[6]} \\
{[27]}\end{array}$ & $\begin{array}{l}\text { S irrad. comp. with PNDA } \\
\text { PR comp. with CNS } \\
\text { S irrad. comp. with PNDA } \\
\text { PR comp. with } \text { CNS }^{-}\end{array}$ & $\begin{array}{l}\text { Rel. to } k_{\mathrm{OH}+\mathrm{C}_{2} \mathrm{H}_{5} \mathrm{OH}}=1.85 \times 10^{9} \\
\text { Rel. to } k_{\text {thiocyan. }}^{\text {rel. }}=1.1 \times 10^{10} \\
\text { Rel. to } k_{\mathrm{OH}+\mathrm{C}_{2} \mathrm{H}_{5} \mathrm{OH}}=1.85 \times 10^{9} \\
\text { Rel. to } k_{\text {thiocyan. }}^{\text {rel. }}=1.1 \times 10^{10}\end{array}$ \\
\hline ethylenediamine & $1.0 \times 10^{8}$ & 5 & {$[28]$} & S irrad. comp. with isopropanol & Rel. to $k_{\mathrm{OH}+\text { isopropanoi }}=2.0 \times 10^{9}$ \\
\hline formamide & $<5 \times 10^{8}$ & 5.5 & {$[29]$} & PR comp. with $\mathrm{CNS}^{-}$ & Rel. to $k_{\text {thiocyan. }}^{\text {rei. }}=1.1 \times 10^{10}$ \\
\hline acetamide & $\begin{array}{l}1.9 \times 10^{8} \\
1.3 \times 10^{7}\end{array}$ & $\begin{array}{l}5.5 \\
9\end{array}$ & $\begin{array}{r}{[29]} \\
{[6]}\end{array}$ & $\begin{array}{l}\text { PR comp. with CNS- } \\
\text { S irrad. comp. with PNDA }\end{array}$ & $\begin{array}{l}\text { Rel. to } k_{\text {thiocyan. }}^{\text {rel. }}=1.1 \times 10^{10} \\
\text { Rel. to } k_{\mathrm{OH}+\mathrm{C}_{2} \mathrm{H}_{5} \mathrm{OH}}=1.85 \times 10^{9}\end{array}$ \\
\hline acrylamide & $\begin{array}{l}(3.3 \pm 0.8) \times 10^{9} \\
(3.3 \pm 0.2) \times 10^{9}\end{array}$ & $\begin{array}{l}\text { neut. } \\
10.7\end{array}$ & $\begin{array}{l}{[30]} \\
{[13]}\end{array}$ & $\begin{array}{l}\text { PR comp. with CNS- } \\
\mathrm{S} \text { irrad. comp. with } \\
\text { benzoate }\end{array}$ & $\begin{array}{l}\text { Rel. to } k_{\text {thiocyan. }}^{\text {rel. }}=1.1 \times 10^{10} \\
\text { Rel. to } k_{\mathrm{OH}+\text { benzoate }}=5.6 \times 10^{9}\end{array}$ \\
\hline acetonitrile & $3.5 \times 10^{6}$ & 9 & {$[6]$} & S irrad. comp. with PNDA & Rel. to $k_{\mathrm{OH}+\mathrm{C}_{2} \mathrm{HsOH}}=1.85 \times 10^{9}$ \\
\hline$N$-methylformamide & $1.2 \times 10^{9}$ & 5.5 & {$[29]$} & PR comp. with $\mathrm{CNS}^{-}$ & Rel. to $k_{\text {thiocyan. }}^{\text {rel. }}=1.1 \times 10^{10}$ \\
\hline$N$-dimethylacetamide & $1.7 \times 10^{9}$ & 5.5 & {$[29]$} & PR comp. with $\mathrm{CNS}^{-}$ & Rel. to $k_{\text {thiocyan. }}^{\text {rel. }}=1.1 \times 10^{10}$ \\
\hline$N$-methylacetamide & $1.6 \times 10^{9}$ & 5.5 & {$[29]$} & PR comp. with $\mathrm{CNS}^{-}$ & Rel. to $k_{\text {thiocyan. }}^{\text {rel. }}=1.1 \times 10^{10}$ \\
\hline$N$-dimethylacetamide & $3.5 \times 10^{9}$ & 5.5 & {$[29]$} & PR comp. with $\mathrm{CNS}^{-}$ & Rel. to $k_{\text {thlocyan. }}^{\text {rel. }}=1.1 \times 10^{10}$ \\
\hline dimethylacetamide & $1.6 \times 10^{9}$ & $5-6$ & [4] & PR comp. with $\mathrm{CNS}^{-}$ & Rel. to $k_{\text {thiocyan. }}^{\text {rei. }}=1.1 \times 10^{10}$ \\
\hline trimethylacetamide & $1.4 \times 10^{9}$ & $5-6$ & [4] & PR comp. with CNS- & Rel. to $k_{\text {thiocyan. }}^{\text {rel. }}=1.1 \times 10^{10}$ \\
\hline $\begin{array}{l}N \text {-methyldimethyl } \\
\text { acetamide }\end{array}$ & $1.9 \times 10^{9}$ & $5-6$ & [4] & PR comp. with $\mathrm{CNS}^{-}$ & Rel. to $k_{\text {thiocyan. }}^{\text {rel. }}=1.1 \times 10^{10}$ \\
\hline $\begin{array}{l}N \text {-methyltrimethyl } \\
\text { acetamide }\end{array}$ & $2.4 \times 10^{9}$ & $5-6$ & [4] & PR comp. with $\mathrm{CNS}^{-}$ & Rel. to $k_{\text {thiocyan. }}^{\text {rel. }}=1.1 \times 10^{10}$ \\
\hline
\end{tabular}


TABLE 10. Nitrogen compounds-Continued

\begin{tabular}{l|l|c|c|c|c}
\hline \multicolumn{1}{c|}{ Reactant } & $k\left(M^{-1} \mathrm{~s}^{-}\right)$ & $\mathrm{pH}$ & Ref. & Method & Comments \\
\hline $\begin{array}{l}N \text {-dimethyl trimethyl } \\
\text { acetamide }\end{array}$ & $4.0 \times 10^{9}$ & $5-6$ & {$[4]$} & PR comp. with CNS & Rel. to $k_{\text {thiocyan. }}^{\text {rel. }}=1.1 \times 10^{10}$ \\
$N$-tert. butylacetamide & $1.1 \times 10^{9}$ & $5-6$ & {$[4]$} & PR comp. with CNS & Rel. to $k_{\text {thiocyan. }}^{\text {rel. }}=1.1 \times 10^{10}$ \\
propionamide & $7.0 \times 10^{8}$ & $5-6$ & {$[4]$} & PR comp. with CNS & Rel. to $k_{\text {thiocyan. }}^{\text {rel. }}=1.1 \times 10^{10}$ \\
$N$-methyl propionamide & $1.4 \times 10^{9}$ & $5-6$ & {$[4]$} & PR comp. with CNS & Rel. to $k_{\text {thiocyan. }}^{\text {rel. }}=1.1 \times 10^{10}$ \\
\hline
\end{tabular}

\section{Chapter VI. References}

[1] Adams, G. E., and Willson, R. L., Trans. Faraday Soc. 65, 2981 (1969).

[2] Burchill, C. E., and Ginns, I. S., Can. J. Chem. 48, 2628 (1970).

[3] Adams, G. E., Boag, J. W., Current, J., and Michael, B. D., Pulse Radiolysis, Ed. M. Ebert, et al., p. 131 (Academic Press, London and New York, 1965).

[4] Hayon, E., Ibata, T., Lichtin, N. N., and Simic, M., J. Amer. Chem. Soc. 93, 5388 (1971).

[5] Scholes, G., Shaw, P., Willson, R. L., and Ebert, M., Pulse Radiolysis, Ed. M. Ebert et al., p. 151 (Academic Press, London and New York, 1965).

[6] Anbar, M., Meyerstein, D., and Neta, P., J. Chem. Soc. (B), 742 (1966).

[7] Thomas, J. K., Trans. Faraday Soc. 61, 702 (1965).

[8] Neta, P., and Dorfman, L. M., Advances in Chemistry Series No. 81, Radiation Chemistry I, 222, Ed. R. F. Gould (1968).

[9] Baxendale, J. H., Fielden, E. M., and Keene, J. P., Pulse Radiolysis, Ed. M. Ebert et al., p. 217 (Academic Press, London and New York, 1965).

[10] Willson, R. L., Greenstock, C. L., Adams, G. E., Wageman, R., and Dorfman, L. M., Int. J. Rad. Phys. and Chem. 3, 211 (1971).

[11] Kraljic, I., and Trumbore, C. N., J. Amer. Chem. Soc. 87, 2547 (1965).

[12] Shah, S., Trumbore, C. N., Giessner, B., and Park, W., Advances in Chemistry Series No. 81, Radiation Chemistry I, 321, Ed. R. F. Gould (1968).

[13] Matthews, R. W., and Sangster, D. F., J. Phys. Chem. 69, 1938 (1965).
[14] Scholes, G., and Willson, R. L., Trans. Faraday Soc. 63 , 2983 (1967).

[15] Rabani, J. and Stein, G., Trans. Faraday Soc. 58, 2150 (1962).

[16] Hummel, A., and Allen, A. O., Radiat. Res., 17, 302 (1962).

[17] Anbar, M., and Neta, P., J. Chem. Soc. (A), 834 (1967).

[18] Greenstock, C. L., Ng, M., and Hunt, J. W., Advances in Chemistry Series No. 81, Radiation Chemistry I, 379, Ed. R. F. Gould (1968).

[19] Kraljic, I., Chemistry of Ionization and Excitation Ed., G. R. A. Johnson and G. Scholes, p. 303 (Taylor and Francis Ltd., London, 1967).

[20] Hughes, G., and Makada, H. A., Trans. Faraday Soc. 64, 3276 (1968).

[21] Hart, E. J., J. Amer. Chem. Soc. 74, 4174 (1952).

[22] Draganic, I., Proc. Tihany Symp. Akademiai Kiado (Hungary) p. 129 (1966).

[23] Hart, E. J., Thomas, J. K., and Gordon, S., Radiation Res. Suppl. 4., 74 (1964).

[24] Lilie, J., Beck, G., and Henglein, A., Ber. Bunsenges. Phys. Chem. 72, 529 (1968)

[25] Ahmad, M., and Clay, P. G., J. Chem. Soc. 845 (1966).

[26] Asmus, K. D., and Taub, I. A., J. Phys. Chem. 72, 3382 (1968).

[27] Wigger, A., Grunbein, W., Henglein, A., and Land, E. J., Zeit. für Naturforsch. 24b, 1262 (1969).

[28] Anbar, M., Munoz, R. A., and Rona, P., J. Phys. Chem. 67, 2708 (1963).

[29] Hayon, E., Ibata, T., Lichtin, N. N., and Simic, M., J. Amer. Soc. $92,3898(1970)$

[30] Chambers, K. W., Collinson, E., Dainton, F. S., Seddon, W. A., and Wilkinson, F., Trans. Faraday Soc. 63, 1699 (1967). 


\section{Chapter VII. Inorganic Electron Transfer Reactions}

This chapter lists rate constants for reactions of $\mathrm{OH}$ with neutral and charged inorganic compounds. With few exceptions, reactions of this type involve simple electron transfer of $\mathrm{OH}$ to form the hydroxide ion with a corresponding change in the valency state of the donor.

$$
\mathrm{M}^{n+}+\mathrm{OH}=\mathrm{M}^{(n+1)+}+\mathrm{OH}-
$$

or

$$
\mathrm{M}^{n-}+\mathrm{OH}=\mathrm{M}^{(n-1)-}+\mathrm{OH}^{-}
$$

The data in table 11 are listed according to the periodic classification of the elements.

Although $\mathrm{H}_{2}$ is listed here, the isotope effect evident in the significant difference between the $\mathrm{OH}$ reactivities of hydrogen and deuterium indicates that the reactions probably involve direct hydrogen transfer

$$
\mathrm{H}_{2}+\mathrm{OH}=\mathrm{H}_{2} \mathrm{O}+\mathrm{H} \cdot
$$

rather than the formation of an intermediate $\mathrm{H}_{2}^{+}$ion:

$$
\mathrm{H}_{2}+\mathrm{OH}=\mathrm{H}_{2}^{+}+\mathrm{OH}^{-}
$$

However, for convenience, the data for $\mathrm{H}_{2}$ and $\mathrm{D}_{2}$ are viven in this chapter and not in Chapter VI.

For the group I metal cations, $\mathrm{Ag}^{+}[1]$ and $\mathrm{Au}^{+}$ [2], and, presumably, $\mathrm{Cu}^{+}$react with $\mathrm{OH}$ to form higher valency states. Surprisingly, the oxidation of cupric ion to a form of Cu III also proceeds at a rate which is only an order of magnitude lower than that for a diffusion-controlled reaction [3].

Interest in the reaction of $\mathrm{OH}$ with the powerful reducing agent, borohydride ion, centered on its possible value as a means of converting $\mathrm{OH}$ into the highly reducing hydrogen atom [4].

$$
\begin{gathered}
\mathrm{BH}_{4}^{-}+\mathrm{OH}=\mathrm{BH}_{4}+\mathrm{OH}^{-} \\
\mathrm{BH}_{4}=\mathrm{BH}_{3}+\mathrm{H}^{.}
\end{gathered}
$$

Preliminary studies indicated, however, that the $\mathrm{BH}_{4}$ intermediate is sufficiently stable to dissociation to permit it to react with other solutes.

There are some data for reaction of $\mathrm{OH}$ with cations and complex anions of metals of the transition series. With the exception of ferrous ion and thallous ion, data are sparse for the transition complex cations. For the three complexes listed, there is no change in the coordination number following $\mathrm{OH}$ oxidation, although this is not the case for a complex of $\mathrm{Pt} \mathrm{II},\left[\mathrm{Pt} \mathrm{Cl}_{4}\right]^{=}$. The one-electron oxidation state of this anion, a complex of Pt III, is unstable and the reaction proceeds to the ultimate formation of a 6-coordination complex of $\mathrm{Pt}$ IV. The initial reaction is not electron transfer and involves addition of $\mathrm{OH}$ to form an intermediate platinum complex of coordination number five [5].

There are adequate data for the reaction of $\mathrm{OH}$ with carbonate ion. Agreement is good, although there is a $\mathrm{pH}$ effect on the rate constant due to the carbonate-bicarbonate ionic equilibrium. The $\mathrm{CO}_{3}^{-}$radical ion formed in the reaction gives rise to a strong transient absorption spectrum with a maximum at $600 \mathrm{~nm}$. For this and other reasons, the reaction has been used as a reference system in pulse radiolysis competition experiments for the measurement of a large number of $\mathrm{OH}$ rate constants. We recommend that a value of $4.1 \times 10^{8}$ be used for the reference rate constant in such determinations.

As would be expected, the reactivity of the reducing oxy-anions of the three-valent Group 5 and the four-valent Group 6 elements approach diffusionlimited values. Where multiple determinations are available, the agreement is generally quite good.

There is a considerable amount of data available on the reactivity of the halide ions of Group 7; reactivities for the pseudo-halide, thiocyanate ion, $\mathrm{CNS}^{-}$, are also included in this section. For both $\mathrm{Cl}^{-}$and $\mathrm{Br}^{-}$there is a strong effect of acid $\mathrm{pH}$ on the reactivity and for chloride, the effect is particularly marked due to the complex nature of the overall oxidation process [6]. There are numerous determinations of the reactivity of bromide ion with, apparently, good agreement at both acid and neutral $\mathrm{pH}$.

Oxidation of a halide ion, $\mathrm{X}^{-}$, proceeds in two stages:

$$
\begin{aligned}
& \mathrm{OH}+\mathrm{X}^{-}=\mathrm{X} \cdot+\mathrm{OH}^{-}, \\
& \mathrm{X} \cdot+\mathrm{X}^{-} \rightleftharpoons \mathrm{X}_{2}^{-} .
\end{aligned}
$$

In competition experiments designed to measure the $\mathrm{OH}$-reactivity of a second solute, the possibility exists, therefore, of competitive reaction of the intermediate species, $\mathrm{X} \cdot$, with both solutes. If this occurs, relative rate data determined by such methods could be misleading. Rate constants 
measured in pulse radiolysis experiments by direct observation of the rate of formation of the complex radical $\mathrm{X}_{2}^{-}$depend for their validity on the assumption that, in the overall process, reaction (7) is rate-determining. Experiments have been carried out [7] which show that this assumption is not valid. Kinetic analysis of the reaction sequence in the thiocyanate system indicated that the rate constant of reaction (7) is greater than that of reaction (8). In view of the frequency with which the $\mathrm{CNS}^{-}$system has been used as a reference system in kinetic competition studies, the validity of the rate data so determined is discussed in detail in the final chapter.

TABLE 11. Inorganic electron transfer reactions

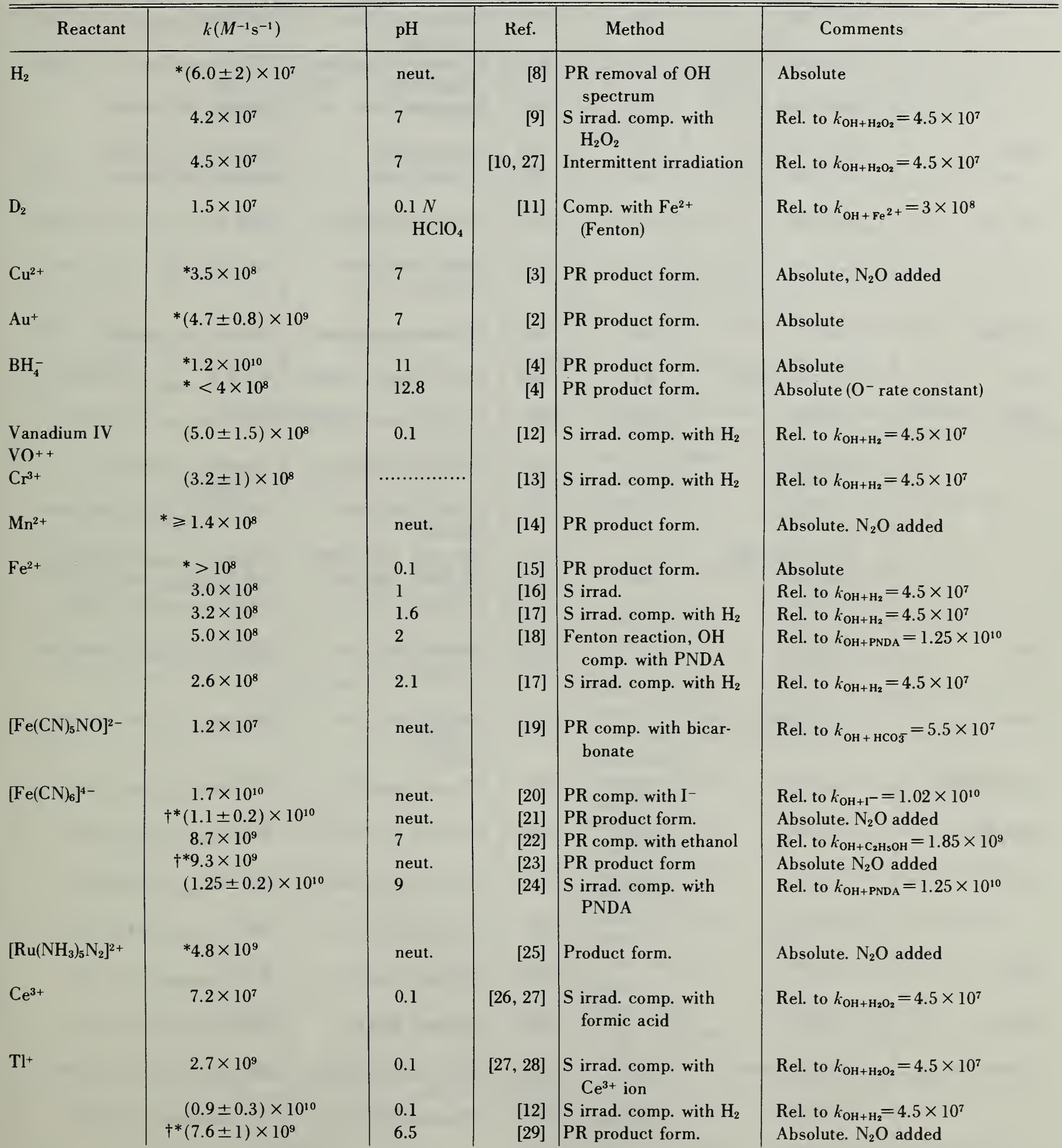


TABLE 11. Inorganic electron transfer reactions-Continued

\begin{tabular}{|c|c|c|c|c|c|}
\hline Reactant & $k\left(M^{-1} \mathrm{~s}^{-1}\right)$ & $\mathrm{pH}$ & Ref. & Method & Comments \\
\hline$\left[\mathrm{PtCl}_{4}\right]^{2-}$ & $\begin{array}{l}* 8 \times 10^{9} \\
* 8 \times 10^{9}\end{array}$ & $\begin{array}{l}7 \\
>13\end{array}$ & $\begin{array}{l}{[30]} \\
{[30]}\end{array}$ & $\begin{array}{l}\text { PR product form. } \\
\text { PR product form. }\end{array}$ & $\begin{array}{l}\text { Absolute. } \mathrm{N}_{2} \mathrm{O} \text { added } \\
\text { Absolute. } \mathrm{N}_{2} \mathrm{O} \text { added }\end{array}$ \\
\hline$\left[\mathrm{Pt}(\mathrm{CN})_{4}\right]^{2-}$ & $1.0 \times 10^{10}$ & 2 & {$[30]$} & PR comp. with methanol & Rel. to $k_{\mathrm{OH}+\mathrm{CH}_{3} \mathrm{OH}}=8.5 \times 10^{8}$ \\
\hline \multirow[t]{4}{*}{$\mathrm{CO}_{\overline{3}}^{\overline{3}}$} & $\dagger^{*} 4.2 \times 10^{8}$ & 10.8 & [31] & PR product form. & Absolute. $\mathrm{N}_{2} \mathrm{O}$ added \\
\hline & $4.5 \times 10^{8}$ & 10.5 & {$[32]$} & $\begin{array}{l}\mathrm{S} \text { irrad. comp. with } \\
\text { benzoate }\end{array}$ & Rel. to $k_{\mathrm{OH}+\text { benzoate }}=5.6 \times 10^{9}$ \\
\hline & $3.8 \times 10^{8}$ & 10.7 & [33] & $\begin{array}{l}\text { PR comp. with methanól } \\
\text { and ethanol }\end{array}$ & Rel. to $k_{\mathrm{OH}+\mathrm{C}_{2} \mathrm{H}_{3} \mathrm{OH}}=1.85 \times 10^{9}$ \\
\hline & $\dagger * 3.65 \times 10^{8}$ & 11 & [34] & PR product form. & Absolute. $\mathrm{N}_{2} \mathrm{O}$ added \\
\hline \multirow[t]{2}{*}{$\mathrm{HCO}_{\overline{3}}$} & ${ }^{*} 1.0 \times 10^{7}$ & 6.5 & [35] & PR prod. form. & Absolute. $\mathrm{CO}_{2}$ added \\
\hline & ${ }^{*} 1.5 \times 10^{7}$ & 8.4 & {$[31]$} & PR prod. form. & Absolute. $\mathrm{N}_{2} \mathrm{O}$ added \\
\hline $\mathrm{CO}$ & $4.5 \times 10^{8}$ & neut. & {$[36]$} & PR comp. with $\mathrm{H}_{2} \mathrm{O}_{2}$ & Rel. to $k_{\mathrm{OH}+\mathrm{H}_{2} \mathrm{O}_{2}}=4.5 \times 10^{7}$ \\
\hline $\mathrm{CN}^{-}$ & $(4.5 \pm 0.3) \times 10^{9}$ & 9 & {$[24]$} & $\begin{array}{l}\text { S irrad. comp. with } \\
\text { PNDA }\end{array}$ & Rel. to $k_{\mathrm{OH}+\mathrm{PNDA}}=1.25 \times 10^{10}$ \\
\hline $\mathrm{C}\left(\mathrm{NO}_{2}\right)_{3}^{-}$ & $* 3 \times 10^{9}$ & neut. & {$[37]$} & PR bleaching of solute & Absolute. $\mathrm{N}_{2} \mathrm{O}$ added \\
\hline $\mathrm{Sn}^{++}$ & $(2.5 \pm 0.3) \times 10^{9}$ & 0.1 & {$[38]$} & $\mathrm{S}$ irrad. comp. with $\mathrm{Fe}^{2+}$ & Rel. to $k_{\mathrm{OH}+\mathrm{Fe}^{2+}}=3.5 \times 10^{8}$ \\
\hline \multirow[t]{6}{*}{$\mathrm{NO}_{2}^{-}$} & $5 \times 10^{9}$ & neut. & [39] & $\mathrm{S}$ irrad. comp. with $\mathrm{H}_{2}$ & Rel. to $k_{\mathrm{NW}+\mathrm{H}_{2}}=4.5 \times 10^{7}$ \\
\hline & $1.3 \times 10^{9}$ & & {$[40]$} & $\mathrm{PR}$ of $\mathrm{NO}_{\overline{3}}$ solutions & $\begin{array}{l}\text { Computer analysis of } \\
\text { reactions }\end{array}$ \\
\hline & $7.1 \times 10^{9}$ & & [41] & $\begin{array}{l}S \text { irrad. comp. with } \\
\text { PNDA }\end{array}$ & Rel. to $k_{\mathrm{OH}+\mathrm{PNDA}}=1.25 \times 10^{10}$ \\
\hline & $(8.1 \pm 0.4) \times 10^{9}$ & 9 & {$[24]$} & PR comp. with PNDA & Rel. to $k_{\mathrm{OH}+\mathrm{P} N \mathrm{NA}}=1.25 \times 10^{10}$ \\
\hline & $7.4 \times 10^{9}$ & 10.7 & [33] & PR comp. with $\mathrm{CO}_{3}^{=}$ & Rel. to $k_{\mathrm{OH}+\mathrm{CO}_{3}}=4.1 \times 10^{8}$ \\
\hline & $8.1 \times 10^{9}$ & 11 & {$[42]$} & PR comp. with $\mathrm{CO}_{3}^{=}$ & Rel. to $k_{\mathrm{OH}+\mathrm{CO}_{3}}=4.1 \times 10^{8}$ \\
\hline NO & $(8.8 \pm 1.1) \times 10^{9}$ & 7 & [43] & $\begin{array}{l}\text { S irrad. comp. with } \\
\text { alcohols }\end{array}$ & Rel. to $k_{\mathrm{OH}+\mathrm{C}_{2} \mathrm{H}_{5} \mathrm{OH}}=1.85 \times 10^{9}$ \\
\hline azide & $(1.08 \pm 0.05) \times 10^{10}$ & 9 & {$[24]$} & $\begin{array}{l}\text { S irrad. comp. with } \\
\text { PNDA }\end{array}$ & Rel. to $k_{\mathrm{OH}+\mathrm{PNDA}}=1.25 \times 10^{10}$ \\
\hline hypophosphite & $1.9 \times 10^{9}$ & 10.7 & {$[33]$} & PR comp. with $\mathrm{CO}_{3}^{=}$ & Rel. to $k_{\mathrm{OH}+\mathrm{CO}_{3}}=4.1 \times 10^{8}$ \\
\hline phosphite & $3.9 \times 10^{9}$ & 10.7 & {$[33]$} & PR comp. with $\mathrm{CO}_{3}=$ & Rel. to $k_{\mathrm{OH}+\mathrm{CO}_{3}}=4.1 \times 10^{8}$ \\
\hline \multirow[t]{2}{*}{$\mathrm{HPO}_{4}^{2-}$} & $<10^{7}$ & neut. & {$[20]$} & PR comp. with iodide & Rel. to $k_{\mathrm{OH}^{+} \mathrm{I}^{-}}=1.02 \times 10^{10}$ \\
\hline & $<5 \times 10^{6}$ & & [44] & PR comp. with $\mathrm{CO}_{3}^{=}$ & Rel. to $k_{\mathrm{OH}+\mathrm{CO}_{\overline{3}}^{\overline{3}}}=4.1 \times 10^{8}$ \\
\hline $\mathrm{PO}_{4}^{3-}$ & $<10^{7}$ & & {$[44]$} & PR comp. with $\mathrm{CO}_{3}^{\overline{3}}$ & Rel. to $k_{\mathrm{OH}+\mathrm{Co}_{3} \overline{\bar{s}}}=4.1 \times 10^{8}$ \\
\hline $\mathrm{P}_{2} \mathrm{O}_{7}^{4-}$ & $<4 \times 10^{6}$ & & {$[44]$} & $\mathrm{PR}$ comp. with $\mathrm{CO}_{3}=$ & Rel. to $k_{\mathrm{OH}+\mathrm{CO}_{3}}=4.1 \times 10^{8}$ \\
\hline \multirow[t]{2}{*}{ arsenite $\left(\mathrm{AsO}_{2}^{-}\right)$} & $(7.6 \pm 0.3) \times 10^{9}$ & 9.0 & {$[24]$} & $\begin{array}{l}\text { S irrad. comp. with } \\
\text { PNDA }\end{array}$ & Rel. to $k_{\mathrm{OH}+\mathrm{PNDA}}=1.25 \times 10^{10}$ \\
\hline & $9.5 \times 10^{9}$ & 10.7 & [33] & PR comp. with $\mathrm{CO}_{3}^{=}$ & Rel. to $k_{\mathrm{OH}+\mathrm{Co}_{3}}=4.1 \times 10^{8}$ \\
\hline
\end{tabular}


TABLE 11. Inorganic electron transfer reactions-Continued

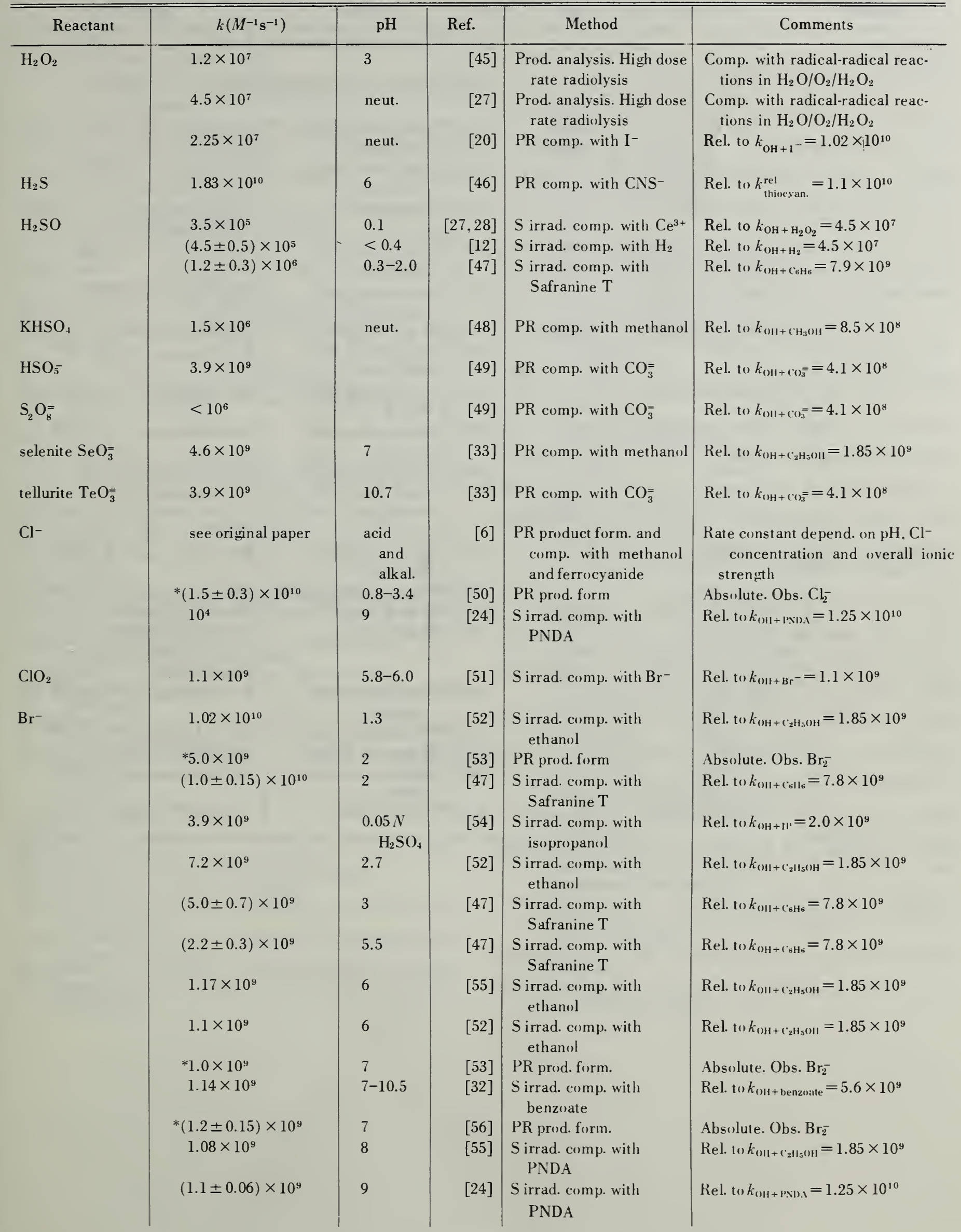


TABLE 11. Inorganic electron transfer reactions - Continued

\begin{tabular}{|c|c|c|c|c|c|}
\hline Reactant & $k\left(M^{-1} \mathrm{~s}^{-1}\right)$ & $\mathrm{pH}$ & Ref. & Method & Comments \\
\hline \multirow{2}{*}{$\begin{array}{l}\text { hypobromite } \\
\mathrm{BrO}^{-}\end{array}$} & $4.4 \times 10^{9}$ & 11 & {$[57]$} & PR comp. with carbonate & Rel. to $k_{\mathrm{OH}+\mathrm{CO}_{3}}=4.1 \times 10^{8}$ \\
\hline & $1.9 \times 10^{9}$ & 13 & {$[57]$} & PR comp. with carbonate & Rel. to $k_{0 \mathrm{H}+\mathrm{CO}_{\overline{3}}}=4.1 \times 10^{8}$ \\
\hline \multirow[t]{11}{*}{$\mathrm{I}^{-}$} & $1.38 \times 10^{10}$ & $\begin{array}{l}0.05 \mathrm{~N} \\
\mathrm{H}_{2} \mathrm{SO}_{4}\end{array}$ & {$[54]$} & $\begin{array}{l}\text { S irrad. comp. with } \\
\text { isopropanol }\end{array}$ & Rel. to $k_{\mathrm{OH}+\mathrm{IP}}=2.0 \times 10^{9}$ \\
\hline & $(1.13 \pm 0.16) \times 10^{10}$ & 2 & {$[47]$} & $\begin{array}{l}\text { S irrad. comp. with } \\
\text { Safranine T }\end{array}$ & Rel. to $k_{\mathrm{OH}+\mathrm{C}_{6} \mathrm{H}_{6}}=7.8 \times 10^{9}$ \\
\hline & $* 3.4 \times 10^{10}$ & $2-7$ & {$[7]$} & PR prod. form. & $\begin{array}{l}\text { Absolute, Analysis of } \mathrm{I}^{+} \mathrm{I}^{-} \rightleftharpoons \mathrm{I}_{2}^{-} \\
\text {equilibrium }\end{array}$ \\
\hline & $(7.5 \pm 1.1) \times 10^{9}$ & $3-5.5$ & {$[47]$} & $\begin{array}{l}\text { S irrad. comp. with } \\
\text { Safranine } T\end{array}$ & Rel. to $k_{\mathrm{OH}+\mathrm{c}_{6} \mathrm{H}_{6}}=7.8 \times 10^{9}$ \\
\hline & $1.6 \times 10^{10}$ & 7 & {$[54]$} & $\begin{array}{l}\text { S irrad. comp. with } \\
\text { isopropanol }\end{array}$ & Rel. to $k_{\mathrm{OH}+\mathrm{IP}}=2.0 \times 10^{9}$ \\
\hline & $*(1.02 \pm 0.13) \times 10^{10}$ & neut. & {$[20]$} & PR product form. & Absolute $\mathrm{N}_{2} \mathrm{O}$ added \\
\hline & $1.2 \times 10^{10}$ & 9 & {$[42]$} & $\begin{array}{l}\text { S irrad. comp. with } \\
\text { PNDA }\end{array}$ & Rel. to $k_{\mathrm{OH}+\mathrm{PNDA}}=1.25 \times 10^{10}$ \\
\hline & $(1.09 \pm 0.06) \times 10^{10}$ & 9 & {$[24]$} & $\begin{array}{l}S \text { irrad. comp. with } \\
\text { PNDA }\end{array}$ & Rel. to $k_{\mathrm{OH}+\mathrm{PNDA}}=1.25 \times 10^{10}$ \\
\hline & $1.37 \times 10^{10}$ & 10.5 & {$[32]$} & $\begin{array}{l}S \text { irrad. comp. with } \\
\text { benzoate }\end{array}$ & Rel. to $k_{\mathrm{OH}+\text { benzoate }}=5.6 \times 10^{9}$ \\
\hline & $7.3 \times 10^{9}$ & 11 & [42] & PR comp. with $\mathrm{CO}_{3}^{=}$ & Rel. to $k_{\mathrm{OH}+\mathrm{CO}_{3}}=4.1 \times 10^{8}$ \\
\hline & $3.4 \times 10^{10}$ & $\begin{array}{l}1.0 M \\
\quad \mathrm{NaOH}\end{array}$ & {$[51]$} & $\begin{array}{l}S \text { irrad. comp. with } \\
\text { isopropanol }\end{array}$ & Rel. to $k_{\mathrm{OH}+\mathrm{IP}}=2.0 \times 10^{9}$ \\
\hline \multirow[t]{9}{*}{ thiocyanate } & $8.6 \times 10^{9}$ & 2 & {$[58]$} & $\begin{array}{l}S \text { irrad. comp. with } \\
\text { thymine }\end{array}$ & Rel. to $k_{\mathrm{OH}+\text { thymine }}=4.7 \times 10^{9}$ \\
\hline & $1.13 \times 10^{10}$ & 2 & {$[33]$} & PR comp. with $\mathrm{C}_{2} \mathrm{H}_{5} \mathrm{OH}$ & Rel. to $k_{\mathrm{OH}+\mathrm{C}_{2} \mathrm{H}_{5} \mathrm{OH}}=1.85 \times 10^{9}$ \\
\hline & $*(7.5 \pm 0.5) \times 10^{9}$ & $2-10$ & {$[59]$} & PR prod. form. & Absolute $\mathrm{N}_{2} \mathrm{O}$ added \\
\hline & ${ }^{*} 2.8 \times 10^{10}$ & $2-9$ & {$[7]$} & PR prod. form. & $\begin{array}{l}\text { Absolute. Analysis of } \\
\text { CNS }+\mathrm{CNS}^{-} \rightleftharpoons \mathrm{CNS}_{2}^{-} \\
\text {equilibrium. }\end{array}$ \\
\hline & $9.2 \times 10^{9}$ & 5 & {$[60]$} & $\begin{array}{l}\mathrm{S} \text { irrad. comp. with } \\
\text { thymine }\end{array}$ & Rel. to $k_{\mathrm{OH}+\text { thymine }}=4.7 \times 10^{9}$ \\
\hline & $1.13 \times 10^{10}$ & 7 & {$[33]$} & PR comp. with $\mathrm{C}_{2} \mathrm{H}_{5} \mathrm{OH}$ & Rel. to $k_{\mathrm{OH}+\mathrm{C}_{2} \mathrm{H}_{5} \mathrm{OH}}=1.85 \times 10^{9}$ \\
\hline & $* 6.6 \times 10^{9}$ & 7 & {$[35]$} & PR form. of $(\mathrm{CNS})_{2}^{-}$ & Absolute $\mathrm{N}_{2} \mathrm{O}$ added \\
\hline & $1.19 \times 10^{10}$ & 9 & [18] & $\begin{array}{l}\text { S irrad. comp. with } \\
\text { PNDA }\end{array}$ & Rel. to $k_{\mathrm{OH}+\mathrm{PNDA}}=1.25 \times 10^{10}$ \\
\hline & $*(1.08 \pm 0.1) \times 10^{10}$ & neut. & {$[61]$} & PR prod. form. & Absolute. $\mathrm{N}_{2} \mathrm{O}$ added. \\
\hline
\end{tabular}




\section{Chapter VII. References}

[1] Baxendale, J. H., Fielden, E. M., and Keene, J. P., Pulse Radiolysis, Ed. M. Ebert et al., p. 207, (Academic Press, London and New York, 1965).

[2] Ghosh-Mazumdar, A. S., and Hart, E. J., Advances in Chemistry Series No. 81, Radiation Chemistry. I, 193, Ed. R. F. Gould, (1968)

[3] Baxendale, J. H., Fielden, E. M., and Keene, J. P., Pulse Radiolysis Ed. M. Ebert et al. p. 217, (Academic Press London and New York, 1966).

[4] Baxendale, J. H., Breccia, A., and Ward, M. D., Int. J. Radiat. Phys. \& Chem. 2, 167 (1970).

[5] Adams, G. E., Broszkiewicz, R. K., and Michael, B. D., Trans. Faraday Soc. 64, 1256 (1968).

[6] Anbar, M., and Thomas, J. K., J. Phys. Chem. 68, 3829 (1964).

[7] Baxendale, J. H., Bevan, P. L. T., and Stott, D. A., Trans. Faraday Soc. 64, 2389 (1968).

[8] Thomas, J. K., J. Phys. Chem. 70, 2409 (1966).

[9] Hochanadel, C. J., J. Phys. Chem. 56, 587 (1952).

[10] Matheson, M. S., Adv. in Chem. Ser. 50, Amer. Chem. Soc., 45 (1965).

[11] Bunn, D., Dainton, F. S., Salmon, G. A., and Hardwick, T. J., Trans. Faraday Soc. 55, 1760 (1959).

[12] Muller, J. C., Ferradini, C., and Pucheault, J., J. Chim. Phys. 63, 232 (1966)

[13] Muller, J. C., and Ferradini, C., J. Chim. Phys. 62, 654 (1965).

[14] Brown, D. M., Dainton, F. S., Walker, D. C., and Keene, J. P. in Pulse Radiolysis, Ed. M. Ebert et al., p. 221 (Academic Press, London and New York, 1965).

[15] Keene, J. P., Radiat. Res. 22, 14 (1964).

[16] Dainton, F. S., and Hardwick, T. J., Trans. Faraday Soc. 53, 333 (1957).

[17] Rothschild, W. G., and Allen, A. O., Radiat. Res. 8, 101 (1958).

[18] Kraljic, I., Chemistry of Ionisation and Excitation, Ed. G.R.A. Johnson and G. Scholes, p. 303 ('Taylor and Francis L.td., London, (1967).

[19] Buxton, G. V., Dainton, F. S., and Kalecinski, J., Int. J. Rad. Phys. \& Chem. 1, 87 (1969).

[20] Thomas, J. K., Trans. Faraday Soc. 61, 702 (1965).

[21] Rabani, J., and Matheson, M. S., J. Amer. Chem. Soc. 86, 3175 (1964).

[22] Adams, G. E., Boag, J. W., and Michael, B. D., Trans. Faraday Soc. 61, 492 (1965).

[23] Willson, R. L., Greenstock, C. L., Adams, G. E., Wageman, R., and Dorfman, L. M. Int. J. Rad. Phys. and Chem. 3, 211 (1971)

[24] Kraljic, I., and Trumbore, C. N., J. Amer. Chem. Soc. 87, 2547 (1965).

[25] Collinson, E., Dainton, F. S., Mile, B., Tazuke, S., and

[26] Sworski, T., Radiat. Res. 6, 645 (1957).

[27] Schwarz, H. A., J. Phys. Chem. 66, 255 (1962).

[28] Sworski, T., Radiat. Res. 4, 483 (1956).

[29] Cercek, B., Ebert, M., and Swallow, A. J., J. Chem. Soc., (A), 612, (1966).

[30] Ghosh-Mazumdar, A. S., and Hart, E. J., Int. J. Rad. Phys. \& Chem. 1, 165 (1969).

[31] Weeks, J. L., and Rabani, J., J. Phys. Chem. 70, 2100 (1966).

[32] Mathews, R. W., and Sangster, D. F., J. Phys. Chem. 69, 1938 (1965).
[33] Adams, G. E., Boag, J. W., Michael, B. D., Trans. Faraday Soc. 61, 1417 (1965).

[34] Behar, D., Czapski, G., and Duchovny, I., J. Phys. Chem. 74, 226 (1970).

[35] Keene, J. P., Raef, Y., and Swallow, A. J., in Pulse Radiolysis, Ed. M. Ebert et al., p. 99 (Academic Press, London and New York, 1965).

[36] Hart, E. J., Thomas, J. K., and Gordon, S., Radiat. Res. Suppl. 4, 74 (1964).

[37] Rabani, J., Mulac, W. A., and Matheson, M. S., J. Phys. Chem. 69,53 (1965).

[38] Boyle, J. W., Weiner, S., and Hochanadel, C. J., J. Phys. Chem. 63, 892 (1959).

[39] Daniels, M., and Wigg, E. E., J. Phys. Chem. 71, 1024 (1967).

[40] Grätzel, M., Henglein, A., and Taniguchi, S., Ber. Bunsenges phys. Chem. 74, 292 (1970).

[41] Shah, S., Trumbore, C. N., Giessner, B., and Park, W. Advances in Chemistry Series No. 81, Radiation Chemistry I, 321, Ed. R. F. Gould (1968).

[42] Buxton, G. V., Trans. Faraday Soc. 65, 2150 (1968).

[43] Woodward, T. W., and Sutton, H. C., Trans. Faraday Soc. 62, 70 (1966).

[44] Black, E. D., and Hayon, E., J. Phys. Chem. 74, 3199 (1970).

[45] Fricke, H., and Thomas, J. K., Radiat. Res., Suppl. 4, 35 (1964).

[46] Karman, W., Meissner, G., and Henglein, A., Zeit. für Naturforsch 22, 273 (1967).

[47] Marketos, D. G., Zeit. für Physik. Chem. Neue Folge 65, 306 (1969).

[48] Heckel, E., Henglein, A., and Beck, G., Ber. Bungenges. Physik. Chem. 70, 149 (1966).

[49] Roebke, W., Renz, M., and Henglein, A., Int. J. Rad. Phys. and Chem. 1, 39 (1969).

[50] Ward, J. F., and Kuo, I., Radiation Chemistry, Adv. in Chem. Series No. 81, p. 368, Ed. R. F. Gould (Amer. Chem. Soc., 1968).

[51] Ferradini, C., and Koulkes-Pujo, A., J. Chim. Phys. 60 , 1310 (1963).

[52] Draganic, I., Proc. Tihany Symp. Radiation Chem., 2nd Tihany Akademiai Kiado, 181, 1966.

[53] Sutton, H. C., Adams, G. E., Boag, J. W., and Michael, B. D., Pulse Radiolysis, Ed. M. Ebert et al. Academic Press, London and New York, p. 6i, 1965.

[54] Hughes, G., and Makada, H. A., Trans. Faraday Soc. 64, 3276 (1968).

[55] Anbar, M., Meyerstein, D., and Neta, P., J. Chem. Soc. (B), 742 (1966).

[56] Matheson, M. S., Mulac, W. A., Weeks, J. L., and Rabani, J., J. Phys. Chem. 70, 2092 (1966).

[57] Buxton, G. V., and Dainton, F. S., Proc. Roy. Soc. A. 304, 427 (1968).

[58] Scholes, G., Shaw, P., Willson, R. L., and Ebert, M., Pulse Radiolysis, Ed. M. Ebert et al., p. 151, (Academic Press, London and New York, 1965).

[59] Greenstock, C. L., Ng, M., and Hunt, J. W., Advances in Chem. Series No. 81, Radiation Chemistry I, 397, Ed. R. F. Gould, (1968).

[60] Scholes, G., and Willson, R. L., Trans. Faraday Soc. 63, 2983 (1967).

[61] Ellison, D. H., Salmon, G. A., and Wilkinson, F., Proc. Roy. Soc. A328, 23 (1972). 


\section{Chapter VIII. Radical Reactions}

Rate constants for the reaction of the hydroxyl radical with another hydroxyl, or with other free radicals (notably those formed in the radiolysis of water) have proved to be among the most difficult of the hydroxyl rate constants to determine accurately. Nevertheless, values have been obtained, in one case by several methods, for the following radical-radical reactions of $\mathrm{OH}$ as well as for three analogous reactions of the deuteroxy radical, OD, the latter in deuterium oxide, rather than in water.

$$
\begin{aligned}
& \mathrm{OH}+\mathrm{OH}=\mathrm{H}_{2} \mathrm{O}_{2} \\
& \mathrm{OH}+\mathrm{O}^{-}=\mathrm{HO}_{2}^{-} \\
& \mathrm{OH}+\mathrm{H}=\mathrm{H}_{2} \mathrm{O} \\
& \mathrm{OH}+e_{\mathrm{aq}}^{-}=\mathrm{OH}^{-} \\
& \mathrm{OH}+\mathrm{HO}_{2}=\mathrm{H}_{2} \mathrm{O}+\mathrm{O}_{2} \\
& \mathrm{OH}+\mathrm{O}_{2}^{-}=\mathrm{OH}^{-}+\mathrm{O}_{2} \\
& \mathrm{OH}+\mathrm{H}_{2} \mathrm{O}_{2}^{+}=\mathrm{H}_{3} \mathrm{O}^{+}+\mathrm{O}_{2} \\
& \mathrm{OD}+\mathrm{OD}=\mathrm{D}_{2} \mathrm{O}_{2}
\end{aligned}
$$

$$
\begin{aligned}
& \mathrm{OD}+\mathrm{D}=\mathrm{D}_{2} \mathrm{O} \\
& \mathrm{OD}+e_{\mathrm{D}_{2} \mathrm{O}}^{-}=\mathrm{OD}^{-}
\end{aligned}
$$

$k_{1}$ has been determined, as pointed out in chapter III, by a method analogous to the rotating sector technique. $k_{1}$ and $k_{3}$ have been determined by pulse radiolysis observation of the hydroxyl radical directly. The molar extinction coefficient must be known for this calculation, and it should be noted that there is a weak overlapping absorption of $\mathrm{H}$ atoms. Several of these rate constants have been determined by computer fitting of over-all product yields in pulsed and steady irradiations, relative to the rate constant for hydrogen atom recombination. These values, dependent as they are upon a fit to many parameters, must be regarded as approximate.

\begin{tabular}{|c|c|c|c|c|c|c|}
\hline Reaction & $k\left(M^{-1} \mathrm{~s}^{-1}\right)$ & $T\left({ }^{\circ} \mathrm{C}\right)$ & $\mathrm{pH}$ & Ref. & Method & Comments \\
\hline \multirow[t]{6}{*}{$\mathrm{OH}+\mathrm{OH}=\mathrm{H}_{2} \mathrm{O}_{2}$} & $\dagger(4.0 \pm 1.0) \times 10^{9}$ & $\mathrm{RT}$ & neut. & {$[1]$} & P rot. sector & $\begin{array}{l}\text { Relative to } k_{\mathrm{OH}+\mathrm{H}_{2}}=4.5 \times 10^{7} \\
\text { Mechanism dependent }\end{array}$ \\
\hline & $\dagger(5.5 \pm 0.8) \times 10^{9}$ & 23 & $\begin{array}{l}\text { acid and } \\
\text { neut. }\end{array}$ & {$[2]$} & PR & Relative to $k_{\mathrm{OH}+\mathrm{ferrocyan}}=0.93 \times 10^{10}$ \\
\hline & $*(5.3 \pm 0.5) \times 10^{9}$ & RT & neut. & {$[3]$} & PR direct obs. of $\mathrm{OH}$ & $\begin{array}{l}\text { Dependent on } \epsilon_{\mathrm{OH}} \text {. Absolute. Corr. } \\
\text { made for } \mathrm{H}+\mathrm{OH} \text {. }\end{array}$ \\
\hline & $*(5.3 \pm 0.5) \times 10^{9}$ & RT & 3 & [4] & PR direct obs. of $\mathrm{OH}$ & Dependent on $\epsilon_{\mathrm{OH}}$. Absolute. \\
\hline & $6 \times 10^{9}$ & RT & acid & [6] & $\begin{array}{l}\text { Prod. yields in } \mathrm{P} \text { and } \mathrm{S} \\
\text { irrad. }\end{array}$ & $\begin{array}{l}\text { Comput. fit to over-all mechanism } \\
\text { with } k_{\mathrm{H}+\mathrm{H}}=6 \times 10^{9}\end{array}$ \\
\hline & $7 \times 10^{9}$ & RT & acid & {$[8]$} & $\begin{array}{l}\text { Prod. yields in } \mathrm{P} \text { and } \mathrm{S} \\
\text { irrad. }\end{array}$ & $\begin{array}{l}\text { Comput. fit to over-all mechanism } \\
\text { with } k_{\mathrm{H}+\mathrm{H}}=6 \times 10^{9}\end{array}$ \\
\hline $\mathrm{OH}+\mathrm{O}^{-}=\mathrm{HO}_{2}^{-}$ & $\leqslant 2.0 \times 10^{10}$ & 23 & basic & {$[2]$} & PR & Relative to $k_{\mathrm{OH}+\text { ferrocyan }}=0.93 \times 10^{10}$ \\
\hline \multirow[t]{3}{*}{$\mathrm{OH}+\mathrm{H}=\mathrm{H}_{2} \mathrm{O}$} & $7 \times 10^{9}$ & $\mathrm{RT}$ & 3 & {$[4]$} & PR direct obs. of $\mathrm{OH}$ & No corr. for overlapping abs. of $\mathrm{H}$ \\
\hline & $1.2 \times 10^{10}$ & RT & acid & [6] & $\begin{array}{l}\text { Prod. yields in } \mathrm{P} \text { and } \mathrm{S} \\
\text { irrad. }\end{array}$ & $\begin{array}{l}\text { Comput. fit to over-all mechanism } \\
\text { with } k_{\mathrm{H}+\mathrm{H}}=6 \times 10^{9}\end{array}$ \\
\hline & $3 \times 10^{10}$ & RT & acid & {$[8]$} & $\begin{array}{l}\text { Prod. yields in } \mathrm{P} \text { and } \mathrm{S} \\
\text { irrad. }\end{array}$ & $\begin{array}{l}\text { Comput. fit to over-all mechanism } \\
\text { with } k_{\mathrm{H}+\mathrm{H}}=6 \times 10^{9}\end{array}$ \\
\hline $\mathrm{OH}+e_{\mathrm{aq}}^{-}+\mathrm{OH}^{-}$ & $*\left(3.0 \pm 1.0 \times 10^{10}\right.$ & 23 & basic & [5] & PR obs. of $e_{\mathrm{aq}}^{-}$ & Mechanism dependent. Absolute. \\
\hline
\end{tabular}
An accurate value for $k_{2}$ has been determined by pulse radiolysis, in competition with the ferrocyanide ion oxidation by $\mathrm{OH}$. For the reactions of $\mathrm{OD}$, there is some uncertainty, since the $p K$ for OD is not precisely known, concerning the extent of involvement of $\mathrm{O}^{-}$in the reactions. The values, as well as a brief indication of the method used along with other pertinent factors, are given in table 12 .

TABLE 12. Radical reactions 
TABLE 12. Radical reactions-Continued

\begin{tabular}{|c|c|c|c|c|c|c|}
\hline Reaction & $k\left(M^{-1} \mathrm{~s}^{-1}\right)$ & $T\left({ }^{\circ} \mathrm{C}\right)$ & $\mathrm{pH}$ & Ref. & Method & Comments \\
\hline $\mathrm{OH}+\mathrm{HO}_{2}=\dot{\mathrm{H}}_{2} \mathrm{O}+\mathrm{O}_{2}$ & $\begin{array}{l}6 \times 10^{9} \\
7.1 \times 10^{9} \\
1.4 \times 10^{10}\end{array}$ & $\begin{array}{l}\text { RT } \\
25 \\
\text { RT }\end{array}$ & $\begin{array}{l}\text { acid } \\
\text { acid } \\
\text { acid }\end{array}$ & $\begin{array}{l}{[6]} \\
{[7]} \\
{[8]}\end{array}$ & $\begin{array}{l}\text { Prod. yields in } \mathrm{P} \text { and } \mathrm{S} \\
\text { irrad. } \\
\text { Prod. yields in } \mathrm{P} \text { irrad. } \\
\text { Prod. yields in } \mathrm{P} \text { and } \mathrm{S} \\
\quad \text { irrad. }\end{array}$ & $\begin{array}{l}\text { Comput. fit to over-all mechanism } \\
\text { with } k_{\mathrm{H}+\mathrm{H}}=6 \times 10^{9} \\
\text { Comput. fit of } \mathrm{G}\left(\mathrm{H}_{2} \mathrm{O}_{2}\right) \text { with } \\
k_{\mathrm{OH}+\mathrm{OH}}=6 \times 10^{9} \\
\text { Comput. fit to over-all mechanism } \\
\text { with } k_{\mathrm{H}+\mathrm{H}}=6 \times 10^{9}\end{array}$ \\
\hline $\mathrm{OH}+\mathrm{O}_{2}^{-}=\mathrm{OH}^{-}+\mathrm{O}_{2}$ & $1.01 \times 10^{10}$ & 25 & $>2.74$ & [7] & Prod. yield in P irrad. & $\begin{array}{l}\text { Comput. fit of } \mathrm{G}\left(\mathrm{H}_{2} \mathrm{O}_{2}\right) \text { with } \\
k_{\mathrm{OH}+\mathrm{OH}}=6 \times 10^{9}\end{array}$ \\
\hline $\mathrm{OH}+\mathrm{H}_{2} \mathrm{O}_{2}^{+}=\mathrm{H}_{3} \mathrm{O}^{+}+\mathrm{O}_{2}$ & $1.27 \times 10^{10}$ & 25 & $<1.51$ & [7] & Prod. yield in P irrad. & $\begin{array}{l}\text { Comput. fit of } \mathrm{G}\left(\mathrm{H}_{2} \mathrm{O}_{2}\right) \text { with } \\
\qquad k_{\mathrm{OH}+\mathrm{OH}}=6 \times 10^{9}\end{array}$ \\
\hline $\mathrm{OD}+\mathrm{OD}=\mathrm{D}_{2} \mathrm{O}_{2}$ & $4.00 \times 10^{9}$ & 23 & basic & [9] & PR obs. of $e_{\mathrm{aq}}^{-}$ & $\begin{array}{l}\text { Concurrent with } \mathrm{OD}+e_{\mathrm{aq}}^{-} \\
\text {Uncertainty about } \mathrm{O}^{-}\end{array}$ \\
\hline $\mathrm{OD}+\mathrm{D}=\mathrm{D}_{2} \mathrm{O}$ & $2.00 \times 10^{10}$ & 23 & basic & [9] & PR obs. of $e_{\mathrm{aq}}^{-}$ & $\begin{array}{c}\text { Concurrent with } \mathrm{OD}+e_{\mathrm{aq}}^{-} \\
\text {Uncertainty about } \mathrm{O}^{-}\end{array}$ \\
\hline $\mathrm{OD}+e_{\mathrm{D}_{2} \mathrm{O}}=\mathrm{OD}^{-}$ & $2.80 \times 10^{10}$ & 23 & basic & [9] & PR obs. of $e_{\mathrm{aq}}^{-}$ & Uncertainty about amount of $\mathrm{O}^{-}$ \\
\hline
\end{tabular}

\section{Chapter VIII. References}

[1] Schwarz, H. A., J. Phys. Chem. 66, 255 (1962).

[2] Rabani, J., and Matheson, M. S., J. Phys. Chem. 70, 761 (1966).

[3] Pagsberg, P., Christensen, H., Rabani, J., Nilsson, G., Fenger, J., and Nielsen, S. O., J. Phys. Chem. 73, 1029 (1969).
[4] Thomas, J. K., Trans. Farad. Soc. 61, 702 (1965).

[5] Matheson, M. S., and Rabani, J., J. Phys. Chem. 69, 1324 (1965).

[6] Thomas, J. K., J. Phys. Chem. 67, 2593 (1963).

[7] Sehested, K., Rasmussen, O. L., and Fricke, H., J. Phys. Chem. 72, 626 (1968).

[8] Fricke, H., and Thomas, J. K., Radiation Res., Supplement No. 4, 35 (1964)

[9] Hart,.E. J., and Fielden, E. M., J. Phys. Chem. 72, 577 (1968). 


\section{Chapter IX. Reactions of the Oxide Radical Ion}

The chemical reactivity of the basic form of the hydroxyl radical, $\mathrm{O}^{-}$, differs markedly from that of $\mathrm{OH}$ in many reactions. Since the $p K$ is 11.9 for the equilibrium

$$
\mathrm{OH}+\mathrm{OH}^{-} \rightleftharpoons \mathrm{O}^{-}+\mathrm{H}_{2} \mathrm{O}
$$

all chemical reactions of the oxide radical ion have been studied in strongly basic solution. The difference in reactivity of $\mathrm{O}^{-}$, compared with $\mathrm{OH}$, may be seen in the following reactions. Whereas the hydroxyl radical is unreactive toward oxygen, the oxide radical ion adds readily to form the ozonide ion:

$$
\mathrm{O}^{-}+\mathrm{O}_{2}=\mathrm{O}_{3}^{-} \text {. }
$$

While the hydroxyl radical adds readily to aromatic molecules, the reactivity of $\mathrm{O}^{-}$toward aromatic compounds is lower by at least three orders of magnitude in the specific rate constant. The $\mathrm{OH}$ radical is much more effective than is the oxide radical ion in oxidizing a number of inorganic anions. Coulombic repulsion of $\mathrm{O}^{-}$, which undoubtedly accounts for part of this difference, is not great enough to account for all of it, and the larger part of the effect may be the result of a lower electron affinity of $\mathrm{O}^{-}$compared with that of $\mathrm{OH}$. Hydrogen abstraction reactions of $\mathrm{O}^{-}$, on the other hand, exhibit a specific reactivity only slightly lower than that of $\mathrm{OH}$ :

$$
\mathrm{O}^{-}+\mathrm{C}_{2} \mathrm{H}_{5} \mathrm{OH}=\mathrm{OH}^{-}+\mathrm{C}_{2} \mathrm{H}_{4} \mathrm{OH}
$$

Rate constants for reactions of $\mathrm{O}^{-}$have been determined in a few cases by direct observation of a transient product in pulse radiolysis. Thus the ozonide ion, formed in reaction (2), has a strong optical absorption with a maximum $[1,6]$ at 430 $\mathrm{nm}$, which has been used [3] to determine $k_{2}$ absolutely. Similarly, $k_{3}$ has been determined absolutely [7] by observing the formation of the $\alpha$-ethanol radical, of which the ionic form $[8,9]$ present at high $\mathrm{pH}$ has a conveniently observable optical absorption in the uv.

In other cases, rate constants have been determined in flash photolysis and in pulse radiolysis by competition kinetic studies $[3,6,10,14]$ using reaction (3), or some other process as the reference reaction. Where the desired result is obtained by monitoring $\mathrm{O}_{3}^{-}$, the interpretation of the data is usually quite complex, involving as it does not only the equilibrium constant for the $\mathrm{pH}$-dependent equilibrium (1), and the forward and reverse rate constants for the thermal equilibrium (2), as well as the rate constant for the reaction of interest, but also the rate constant for the analogous competing reaction of $\mathrm{OH}$. Notwithstanding the complexity, competition kinetics with ozonide formation is a feasible method, since the formation rate constant, $k_{2}$, is reasonably accurately known and the decomposition constant, $k_{2 r}$, has been determined [10] as $3.3 \times 10^{3} \mathrm{~s}^{-1}$ at $25^{\circ} \mathrm{C}$.

Table 13 lists the rate constants for reactions of $\mathrm{O}^{-}$, among which are to be found examples of addition, hydrogen abstraction, and reaction with other radicals and radical ions, notably those formed in

\begin{tabular}{|c|c|c|c|c|c|c|}
\hline Reaction & $k\left(\mathrm{M}^{-1} \mathrm{~s}^{-1}\right)$ & $T\left({ }^{\circ} \mathrm{C}\right)$ & $\mathrm{pH}$ & Ref. & Method & Comments \\
\hline $\mathrm{O}^{-}+\mathrm{O}_{2}=\mathrm{O}_{3}^{-}$ & $\begin{array}{c}\dagger * 2.5 \times 10^{9} \\
* 2.5 \times 10^{9} \\
+*(3.6+0.4) \times 10^{9} \\
4 \times 10^{9}\end{array}$ & $\begin{array}{l}\text { RT } \\
\text { RT } \\
20-25 \\
23\end{array}$ & $\begin{array}{r}13 \\
13-13.7 \\
11 \& 13 \\
11.9\end{array}$ & $\begin{array}{l}{[3]} \\
{[6]} \\
{[11]} \\
{[17]}\end{array}$ & $\begin{array}{l}\text { PR prod. form. } \\
\text { Flash. phot. prod. } \\
\text { form. } \\
\text { PR prod. form. } \\
\text { PR prod. form. }\end{array}$ & $\begin{array}{l}\text { Absolute. Observ. } \mathrm{O}_{3}^{-} \\
\text {Single concen. of } \mathrm{O}_{2} \\
\text { Absolute. Observ. } \mathrm{O}_{3}^{-} \text {in } \\
\mathrm{H}_{2} \mathrm{O}_{2} \text { phot. No data given } \\
\text { Absolute. Observ. of } \mathrm{O}_{3}^{-} \text {form. } \\
\text { Absolute. Approximate }\end{array}$ \\
\hline $\mathrm{O}^{-}+\mathrm{C}_{6} \mathrm{H}_{5} \mathrm{COO}^{-}$ & $<6 \times 10^{6}$ & 2.5 & 13 & {$[4]$} & $\begin{array}{l}\text { PR comp. with } \mathrm{O}_{\overline{3}} \\
\text { form. }\end{array}$ & $\begin{array}{l}\text { Rel. to } k_{0-+0_{2}}=2.5 \times 10^{9} \text {. } \\
\text { Complex kinetics. May be } \\
\text { very much lower. }\end{array}$ \\
\hline
\end{tabular}
the radiolysis of water.

TABLE 13. Reactions of the oxide radical ion 
TABLE 13. Reactions of the oxide radical ion-Continued

\begin{tabular}{|c|c|c|c|c|c|}
\hline Reaction & $k\left(\mathbf{M}^{-1} \mathrm{~s}^{-1}\right)$ & $T\left({ }^{\circ} \mathrm{C}\right)$ & $\mathrm{pH}$ & Ref. & Method \\
\hline $\mathrm{O}^{-}+\mathrm{H}_{2} \mathrm{O}=\mathrm{OH}+\mathrm{OH}^{-}$ & $\begin{array}{l}5.5 \times 10^{2} \\
\left(3.0 \times 10^{4} \mathrm{~s}^{-1}\right) \\
1.7 \times 10^{6} \\
\left(9.2 \times 10^{7} \mathrm{~s}^{-1}\right) \\
2 \times 10^{7}\end{array}$ & $\begin{array}{l}20-25 \\
25\end{array}$ & $13-13.7$ & $\begin{array}{l}{[6]} \\
{[12]} \\
{[10]}\end{array}$ & $\begin{array}{l}\text { Flash phot. } \\
\text { PR comp. with } \\
\mathrm{O}^{-}+\mathrm{CO}_{3}^{2-} \\
\text { Calculated }\end{array}$ \\
\hline $\mathrm{O}^{-}+\mathrm{H}_{2}=\mathrm{OH}^{-}+\mathrm{H}$ & $(8 \pm 4) \times 10^{7}$ & 23 & 13 & [13] & PR observ. of $e_{\mathrm{aq}}^{-}$ \\
\hline $\mathrm{O}^{-}+\mathrm{HO}_{2}^{-}=\mathrm{OH}^{-}+\mathrm{O}_{2}^{-}$ & $\begin{array}{l}(7 \pm 3) \times 10^{8} \\
8.1 \times 10^{8} \\
(5.0 \pm 1.7) \times 10^{8} \\
2.74 \times 10^{8}\end{array}$ & $\begin{array}{l}25 \\
20-25 \\
\text { RT } \\
24\end{array}$ & $\begin{array}{r}13 \\
11 \\
13-13.7 \\
12-13.5\end{array}$ & $\begin{array}{r}{[4]} \\
{[11]} \\
{[6]} \\
{[21]}\end{array}$ & $\begin{array}{l}\text { PR observ. of } \mathrm{O}_{3}^{-} \\
\text {PR comp. with } \\
\mathrm{OH}+\mathrm{CO}_{3}^{2-} \\
\text { PR observ. of } \mathrm{O}_{3}^{-} \\
\text {PR comp. with } \\
\mathrm{O}^{-}+\mathrm{O}_{2}\end{array}$ \\
\hline $\begin{array}{l}\mathrm{O}^{-}+\mathrm{CH}_{3} \mathrm{OH} \\
\quad=\cdot \mathrm{CH}_{2} \mathrm{OH}+\mathrm{OH}^{-}\end{array}$ & $\begin{array}{c}\dagger(5.2 \pm 1.0) \times 10^{8} \\
\dagger^{*}(5.8 \pm 0.8) \times 10^{8}\end{array}$ & $\begin{array}{l}25 \\
25\end{array}$ & $\begin{array}{r}13 \\
>13.3\end{array}$ & $\begin{array}{l}{[10]} \\
{[7]}\end{array}$ & $\begin{array}{l}\text { PR observ. of } \mathrm{O}_{\overline{3}} \\
\text { decay } \\
\text { PR prod. form. }\end{array}$ \\
\hline $\begin{array}{l}\mathrm{O}^{-}+\mathrm{C}_{2} \mathrm{H}_{5} \mathrm{OH} \\
=\cdot \mathrm{C}_{2} \mathrm{H}_{4} \mathrm{OH}+\mathrm{OH}^{-}\end{array}$ & $\begin{array}{c}+8.9 \times 10^{8} \\
+(8.4 \pm 1.6) \times 10^{8} \\
\dagger^{*}(1.13 \pm 0.17) \times 10^{9}\end{array}$ & $\begin{array}{l}\mathrm{RT} \\
25 \\
25\end{array}$ & $\begin{array}{r}>13 \\
13 \\
>13.3\end{array}$ & $\begin{array}{l}{[14]} \\
{[10]} \\
{[7]}\end{array}$ & $\begin{array}{l}\text { PR observ. of } \mathrm{O}_{\overline{3}}^{-} \\
\text {PR observ. of } \mathrm{O}_{\overline{3}}^{-} \\
\text {decay } \\
\text { PR prod. form. }\end{array}$ \\
\hline $\begin{array}{l}\mathrm{O}^{-}+\mathrm{C}_{2} \mathrm{O}_{4}^{2-} \\
\quad=\mathrm{CO}_{2}+20 \mathrm{H}^{-}+\mathrm{CO}_{2}^{-}\end{array}$ & $1.6 \times 10^{7}$ & 24 & $12-13.5$ & [15] & $\mathrm{S}$ irrad. $\mathrm{CO}_{2}$ form. \\
\hline $\begin{array}{l}\mathrm{O}^{-}+\left[\mathrm{Fe}(\mathrm{CH})_{6}\right]^{4-} \\
\stackrel{\mathrm{H}_{2} \mathrm{O}}{=}\left[\mathrm{Fe}(\mathrm{CN})_{6}\right]^{3-}+2 \mathrm{OH}^{-}\end{array}$ & $<7 \times 10^{7}$ & 23 & 13.5 & [17] & $\begin{array}{l}\text { PR comp. with } \\
\text { OH + ferro- } \\
\text { cyanide }\end{array}$ \\
\hline $\mathrm{O}^{-}+\mathrm{CO}_{3}^{2-} \stackrel{\mathrm{H}_{2} \mathrm{O}}{=} \mathrm{CO}_{3}^{-}+2 \mathrm{OH}^{-}$ & $<10^{7}$ & 23 & $10.6-13.5$ & {$[16]$} & PR prod. form. \\
\hline $\begin{array}{l}\mathrm{O}^{-}+\mathrm{HCO}_{2}^{-} \\
\stackrel{\mathrm{H}_{2} \mathrm{O}}{=} \mathrm{HCO}_{2}+2 \mathrm{OH}^{-}\end{array}$ & $1.4 \times 10^{9}$ & $20-25$ & 11 & [11] & $\begin{array}{l}\text { PR comp. with } \\
\mathrm{OH}+\mathrm{CO}_{3}^{2-}\end{array}$ \\
\hline $\mathrm{O}^{-}+\mathrm{NO}_{2}^{-} \stackrel{\mathrm{H}_{2} \mathrm{O}}{=} \mathrm{NO}_{2}+2 \mathrm{OH}^{-}$ & $2.8 \times 10^{8}$ & $20-25$ & 11 & [11] & $\begin{array}{l}\text { PR comp. with } \\
\mathrm{OH}+\mathrm{CO}_{3}^{2-}\end{array}$ \\
\hline $\mathrm{O}^{-}+\mathrm{I}^{-} \stackrel{\mathrm{H}_{2} \mathrm{O}}{=} \mathrm{I}+2 \mathrm{OH}^{-}$ & $9.6 \times 10^{8}$ & $20-25$ & 11 & [11] & $\begin{array}{c}\text { PR comp. with } \\
\mathrm{OH}+\mathrm{CO}_{3}^{2-}\end{array}$ \\
\hline $\begin{array}{l}\mathrm{O}^{-}+\mathrm{CNS}^{-} \\
\stackrel{\mathrm{H}_{2} \mathrm{O}}{=} \mathrm{CNS}+2 \mathrm{OH}^{-}\end{array}$ & $1.0 \times 10^{9}$ & & $>12$ & [19] & $\begin{array}{l}\text { PR comp. with } \\
\mathrm{O}^{-}+\mathrm{O}_{2}\end{array}$ \\
\hline
\end{tabular}

Comments

Rel. to $\mathrm{k}_{\mathrm{O}^{-}+\mathrm{O}_{2}}=2.5 \times 10^{9}$

Rel. to $k_{0^{-}+\mathrm{C}_{2} \mathrm{H}_{5} \mathrm{OH}}=1 \times 10^{9}$

Based on equilibrium consts. and $k_{() \mathrm{H}+(\mathrm{HH}}=4 \times 10^{9}$

Comput. fit with other rate consts. and depend. upon $\epsilon_{e-}^{-}$

Rel. to $k_{0-+O_{2}}=2.5 \times 10^{9}$

Rel. to $k_{\mathrm{OH}}+\mathrm{CO}_{3}^{2-}=4.1 \times 10^{8}$

Rel. to $k_{\mathrm{O}^{-}+\mathrm{O}_{2}}=2.5 \times 10^{9}$

Rel. to $k_{\mathrm{O}^{-}+\mathrm{O}_{2}}=2.5 \times 10^{9}$

Corr. to zero ionic strength

Rel. to $k_{0^{-}+O_{2}}=2.5 \times 10^{9}$

Absolute. Observ. of alcohol radical form.

Rel. to $k_{0-+O_{2}}=2.5 \times 10^{9}$

Rel. to $k_{0^{-}+O_{2}}=2.5 \times 10^{9}$

Absolute. Observ. of alcohol radical form.

Rel. to $k_{0^{-}+\mathrm{O}_{2}}=2.5 \times 10^{9}$

Approx. upper limit

Absolute. Approx. limit.

Rel. to $k_{\mathrm{OH}}+\mathrm{CO}_{3}^{2}-=4.1 \times 10^{8}$

Rel. to $k_{\mathrm{OH}}+\mathrm{CO}_{3}^{2}-=4.1 \times 10^{8}$

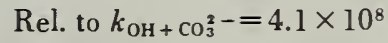

Rel. to $k_{\mathrm{O}^{-}+\mathrm{O}_{2}}=2.5 \times 10^{9}$ 
TABLE 13. Reactions of the oxide radical ion-Continued

\begin{tabular}{|c|c|c|c|c|c|c|}
\hline Reaction & $k\left(\mathrm{M}^{-1} \mathrm{~s}^{-1}\right)$ & $T\left({ }^{\circ} \mathrm{C}\right)$ & $\mathrm{pH}$ & Ref. & Method & Comments \\
\hline \multirow[t]{4}{*}{$\mathrm{O}^{-}+\mathrm{O}^{-}=\mathrm{O}_{2}^{2-}$} & $5.8 \times 10^{9}$ & RT & 13 & [3] & $\begin{array}{l}\mathrm{PR} \text { comp. with } \mathrm{O}_{3}^{-} \\
\text {form. }\end{array}$ & $\begin{array}{l}\text { Rel. to } k_{0-+0_{2}}=2.5 \times 10^{9} . \mathrm{N}_{2} \mathrm{O} \\
\text { added }\end{array}$ \\
\hline & $2 \times 10^{9}$ & 23 & $12-13$ & {$[18]$} & $\begin{array}{l}\text { PR comp. with } \\
\text { OH }+ \text { ferro- } \\
\text { cyanide }\end{array}$ & Rel. to $\mathrm{OH}+\left[\mathrm{Fe}(\mathrm{CN})_{6}\right]^{4-}$ \\
\hline & $<1.8 \times 10^{9}$ & 23 & $12-13$ & {$[17]$} & $\begin{array}{l}\text { PR comp. with } \\
\text { OH + ferro- } \\
\text { cyanide }\end{array}$ & May be much less \\
\hline & $<8 \times 10^{8}$ & 23 & 13 & {$[20]$} & $\begin{array}{l}\text { PR comp. with } \\
\text { OH + ferro- } \\
\text { cyanide }\end{array}$ & Recalculated from ref. [17] \\
\hline $\mathrm{O}^{-}+\mathrm{OH}=\mathrm{HO}_{2}^{-}$ & $<2.6 \times 10^{10}$ & 23 & $12-13$ & {$[17]$} & $\begin{array}{l}\text { PR comp. with } \\
\mathrm{OH}+\text { ferro- } \\
\text { cyanide }\end{array}$ & May be 4-fold lower \\
\hline $\mathrm{O}^{-}+e_{\mathrm{aq}}^{-} \stackrel{\mathrm{H}_{2} \mathrm{O}}{=} \mathrm{OH}^{-}$ & $(2.2 \pm 0.6) \times 10^{10}$ & 23 & $>13$ & {$[13]$} & PR observ. of $e_{\mathrm{aq}}^{-}$ & $\begin{array}{l}\text { Comp. fit with other rate } \\
\text { constants }\end{array}$ \\
\hline $\mathrm{O}^{-}+\mathrm{O}_{3}^{-} \stackrel{?}{\rightarrow}$ & $5 \times 10^{8}$ & 25 & 13 & {$[10]$} & $\begin{array}{l}\text { PR observ. of } \mathrm{O}_{3}^{-} \\
\text {decay }\end{array}$ & Rel. to $k_{0^{-}+0_{2}}=2.5 \times 10^{9}$ \\
\hline
\end{tabular}

\section{Chapter IX. References}

[1] Czapski, G., and Dorfman. L. M., J. Phys. Chem. 68, 1169 (1964).

[2] Adams, G. E., and Boag, J. W., Proc. Chem. Soc., 112 (1964).

[3] Adams, G. E., Boag, J. W., and Michael, B. D., Proc. Roy Soc. 289A, 321 (1966).

[4] Felix, W. D., Gall, B. L., and Dorfman, L. M., J. Phys. Chem. 71, 384 (1967).

[5] Heidt, L. J., and Landi, V. R., J. Chem. Phys. 41, 176 (1964).

[6] Behar, D., and Czapski, G., Israel J. Chem. 6, 43 (1968).

[7] W ander, R., Gall, B. L., and Dorlman, L. M., J. Phys. Chem. 74, 1819 (1970).

[8] Asmus, K. D., Henglein, A., Wigger, A., and Beck, G., Ber. Bunsengesell Physik. Chem. 70, 756 (1966).

[9] Simic, M., Neta, P., and Hayon, E., J. Phys. Chem. 73, 3794 (1969).

[10] Gall, B. L., and Dorfman, I. M., J. Am. Chem. Soc. 91, 2199 (1969).
[11] Buxion, (,. V., Trans. Farad. Soc. 65, 2150 (1969).

[12] Buxton, G. V., Trans. Farad. Soc. 66, 1656 (1970).

[13] Matheson, M. S., and Rabani, J., J. Phys. Chem. 69, 1324 (1965).

[14] Adams, G. E., Boag, J. W., and Mirliael, B. D., Trans. Farad. Soc. 61, 492 (1965).

[15] Draganic, Z. D., Draganic, I. G., and Kosanic, M. M., J. Phys. Chem. 70, $1418(1966)$

[16] Weeks, J. L., and Rabani, J., J. Phys. ('hem. 70, 2100 (1966).

[17] Rabani. J., and Matheson, M. S., J. Phys. Clıem. 70, 761 (1966).

[18] Rabani, J., and Matheson, M. S., J. Am. Chem. Soc. 86, 3175 (1964).

[19] Adams, G. E., Boag, J. W., Currant, J., and Michael, B. D., Pulse Radiolysis, Ed., M. Ebert, et al., p. 117 (Academic Press, N.Y., 1965).

[20] Rabani, J., Radiation Chemistry of Aqueous Systems, Ed., G. Stein, p. 229 (Weizmann Press 1968).

[21] Rabani, J., Advances in Chemistry Series, No. 81, Radiation Chemistry I, 131 Ed. R. F. Gould (1968). 


\section{Chapter X. Reactions With Biological Molecules}

There is an extensive literature on the reactions of the $\mathrm{OH}$ radical with compounds relevant to, or involved in, many biochemical and biological processes. Reactions studied include oxidative deamination of aliphatic amino acids; addition to the free bases, nucleotides, and nucleosides derived from the nucleic acids; hydrogen abstraction involving the thiol group in cysteine and other sulfurcontaining compounds and carbohydrates; and also, various investigations of $\mathrm{OH}$-oxidation of biologically-active macromolecules including enzymes and nucleic acid itself. In this chapter the data for the compounds are presented in separate tables grouped according to general biochemical type.

\section{Amino Acids}

It is now well established that oxidative and reductive deamination are major processes in the radiolysis of dilute aqueous solutions of simple aliphatic amino acids such as glycine and alanine [1]. It is believed that $\mathrm{OH}$ attack on amino acids of this type, represented as $\mathrm{NH}_{3}^{+} \mathrm{CH}(\mathrm{R}) \mathrm{COO}^{-}$, occurs mainly at the carbon atom alpha to the carboxyl or amino group.

$$
\mathrm{OH}+\mathrm{NH}_{3}^{+} \mathrm{CH}(\mathrm{R}) \mathrm{COO}^{-}=\mathrm{H}_{2} \mathrm{O}+\mathrm{NH}_{3}^{+} \dot{\mathrm{C}}(\mathrm{R}) \mathrm{COO}^{-}
$$

Dependent upon experimental conditions, the $\alpha$ amino radical may react by dismutation to form an intermediate imino-cation which hydrolyzes to yield ammonia and a keto acid:

$$
\begin{gathered}
2 \mathrm{NH}_{3}^{+} \mathrm{C}(\mathrm{R}) \mathrm{COO}^{-}=\mathrm{NH}_{3}^{+} \mathrm{CH}(\mathrm{R}) \mathrm{COO}^{-} \\
+\mathrm{NH}_{2}=\mathrm{C}(\mathrm{R}) \mathrm{COO}^{-} \\
\mathrm{NH}_{2}^{+}=\mathrm{C}(\mathrm{R}) \mathrm{COO}^{-}+\mathrm{H}_{2} \mathrm{O}=\mathrm{NH}_{4}+\mathrm{RCOCOO}^{-}
\end{gathered}
$$

Although there is an approximate 1:1 stoichiometry between $\mathrm{OH}$ disappearance and ammonia production, this is not so for aliphatic amino acids containing longer side chains. For example, in the radiolysis of such amino acids in dilute aqueous solution, the efficiency of ammonia production falls with increasing length of the aliphatic side chain [2]. This is due to the reduction in the yield of the $\alpha$-amino radical relative to that of radicals formed by $\mathrm{OH}$ attack elsewhere in the molecule.

Oxidative deamination is not a major process following the reaction of $\mathrm{OH}$ with the ring-containing amino acids, e.g. tyrosine, phenylalanine, tryptophan, and histidine. As might be expected by analogy with other aromatic and heterocyclic compounds, $\mathrm{OH}$ radicals react predominantly by addition to the ring. In the case of tyrosine, the hydroxycyclohexadienyl radical formed in this reaction undergoes a unimolecular elimination reaction in which a molecule of water is lost from the structure [3].
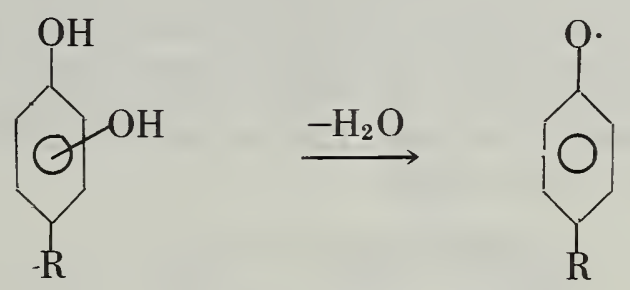

The reaction is acid-base catalyzed.

The rate constants for $\mathrm{OH}$ addition to the ringamino acids are an order of magnitude or more larger than those for the non-ring amino acids, with the exception of the sulfur-containing compounds. For this reason therefore, the ring structures in enzymes are particularly vulnerable to $\mathrm{OH}$ radical attack, reactions which may lead, in some cases, to loss of biological activity.

In the heterocyclic amino acid, tryptophan, there is evidence of multifocal attack by $\mathrm{OH}$. This is based on the analysis of the stable products following radiolysis of aqueous solutions [4] and also, on a study of the reactions of $\mathrm{OH}$ generated in the Fenton reaction [5]. A detailed pulse radiolysis study of tryptophan and related substituted indoles not only confirmed that multifocal attack occurs but has also provided information on which sites in the ring are involved [6]. The transient absorption maximum due to the $\mathrm{OH}$-adduct has three subsidiary maxima at 310,325 , and $345 \mathrm{~nm}$. The spectrum was compared with those obtained by $\mathrm{OH}$ addition to indoles in which substituent groups were present at various positions in the structures. It was found that the relative intensities of the three subsidiary maxima are dependent upon the position of the substituent. It was argued that substitution of a methyl group on various positions of the indole ring should restrict electrophilic attack by $\mathrm{OH}$ at that position. Complications arising from changes in the electron density distribution in the molecule due to the inductive effect of the methyl group appear to be negligible since the molecular spectrum of indole is not very different from those of the substituted indoles. It was concluded that the effect of substitution on the relative intensities of the subsidiary maxima in 
the transient spectra reflect the lowering of the probability of $\mathrm{OH}$ attack at the substituted position. Kinetic data indicated that the $\mathrm{OH}$ reactivities at the three sites in tryptophan were of the same order of magnitude, from which it was concluded that the three $\mathrm{OH}$-adducts are formed in approximately equal yield.

It is evident from table 14, that the sulfur-containing amino acids react extremely rapidly with $\mathrm{OH}$. Cysteine ( $\mathrm{RSH})$ is oxidized to cystine through the formation of the intermediate radical RS which results from abstraction of a hydrogen atom from the thiol group

$$
\mathrm{RSH}+\mathrm{OH}=\mathrm{RS} \cdot+\mathrm{H}_{2} \mathrm{O}
$$

It has been shown by pulse radiolysis studies on cysteine-related compounds including $\mathrm{H}_{2} \mathrm{~S}$ and simple mercaptans $[7,8]$, that under nonacidic conditions, the intermediate RS radical complexes with a solute molecule to form the ion-radical RSSRaccording to the equilibria

$$
\begin{gathered}
\mathrm{RSH} \rightleftharpoons \mathrm{RS}^{-}+\mathrm{H}^{+} \\
\mathrm{RS}+\mathrm{RS}^{-} \rightleftharpoons \mathrm{RSSR}^{-} .
\end{gathered}
$$

Cystine is probably formed by dimerization of the uncomplexed $\mathrm{RS}$ radicals

$$
\mathrm{RS}+\mathrm{RS}=\mathrm{RSSR} \text {. }
$$

In the presence of oxygen, the high efficiency for the oxidation of $\mathrm{RSH}$ indicates the occurrence of a chain reaction [9]. It has been suggested that the $\mathrm{RS}$ radicals formed in (6) react with oxygen to form the $\mathrm{RSO}_{2}$ radical which propagates the chain by the $\mathrm{H}$-atom transfer reaction

$$
\mathrm{RSO}_{2}+\mathrm{RSH}=\mathrm{RSO}_{2} \mathrm{H}+\mathrm{RS} .
$$

The chain termination step is dimerization of RS radicals to from cystine. Thiourea is rapidly oxidized by $\mathrm{OH}$ radicals [10]. It has been suggested that the reaction proceeds through a transient intermediate imino radical formed by hydrogen abstraction from the imino form of the solute.<smiles>N=C(S)N=NC(N)=S</smiles><smiles>NC(S)=NONC(=[SH+])NO</smiles>

A strong transient absorption band with a maximum near $400 \mathrm{~nm}$, is formed during the pulse radiolysis of thiourea solutions [10]. This was attributed originally to the imino-RS radical formed in reaction (11). However, more recent pulse radiolysis studies with the analogue selenourea [11], where a similar absorption band is observed, indicate that the absorption band is due to a radical anion-dimer analogous to the species RSSR-formed by $\mathrm{OH}$ oxidation of thiols.

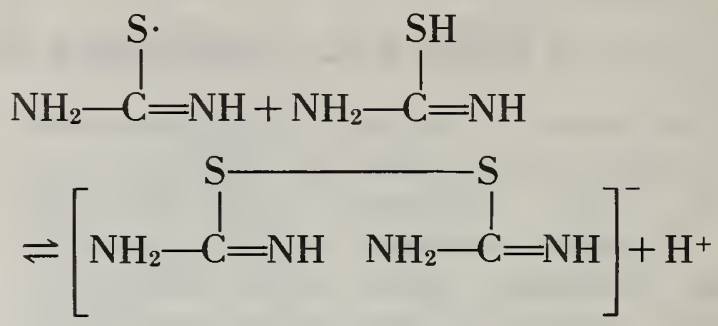

Some trends are apparent in the rate constant data listed in the tables. Clearly the absolute reactivities of $\mathrm{OH}$ with amino acids (table 15) and simple peptides (table 16) vary considerably with the structure of the compound and also with $\mathrm{pH}$, an effect which is due to the influence of the ionic equilibria in these solutes. With increasing $\mathrm{pH}$, the net charge on amino acids changes from +1 in acid solution through zero to -1 in alkaline solutions which favors reaction with the electrophile $\mathrm{OH}$.

The simple aliphatic amino acids, glycine and alanine, appear to be the least reactive although when $\mathrm{OH}$ groups or branched chains are present in the molecules, inductive effects tend to increase the reactivity. As discussed earlier, the ring-structured amino acids are among the most reactive due to the ease with which $\mathrm{OH}$ addition to the $\pi$-electron system can occur. Similar trends are apparent in the data for the simple peptides although the peptide linkage evidently increases the reactivity relative to that of the free amino acids. As might be expected, in peptides where the component amino acids have different reactivities in the free state, e.g., glutathione and glycyltyrosine, the rate constants are comparable in each case to that of the more reactive amino acid component.

\section{Enzymes}

Table 17 lists the available data for some relatively simple enzymes. In most cases, the rate constants are of the order of $10^{11} M^{-1} \mathrm{~s}^{-1}$, values which are calculated on the basis of the total molecular weight of the enzymes. Since these compounds contain in excess of 100 amino acids in their structure, the rate constants calculated on the basis of the total molarity of the individual component amino acids are of course considerably smaller. Although attempts have been made to calculate overall rate constants from a knowledge of the values for the single units, such calculations are of doubtful significance in view of the complex tertiary structure of enzymes and the varying degrees of accessibility to free radical attack of different regions in the molecules.

Overall rate constants have been measured by pulse radiolysis and stationary-state methods. Data obtained by competition techniques are less reliable than those determined by absolute methods due to 
the problems of kinetic inhomogeneity encountered in systems containing very large macromolecules. Fortunately, rate constants can be measured quite conveniently by the absolute pulse radiolysis methods since $\mathrm{OH}$ attack on proteins gives rise to strong transient absorption bands in the ultraviolet region of the spectrum. These absorption bands are due to addition of $\mathrm{OH}$ to the ring-amino acids present in the structure.

\section{Nucleic Acid Derivatives}

The relationship between intracellular damage to DNA and the response of the cell (lethal or otherwise) to ionizing radiation is one of the most fundamental problems of radiobiology. It is not surprising therefore that much effort has been devoted to the study of the radiation chemistry of DNA and its constituent nucleotides, nucleosides, and free bases.
It is from this field of research that almost all of the available information on $\mathrm{OH}$ reactivities with these compounds derives. It is relevant therefore to discuss first some of the early work on the stationary-state radiation chemistry of these compounds.

Dilute aqueous solutions of simple pyrimidine bases, e.g., thymine, cytosine, and uracil are bleached by ionizing radiation $[12,13]$. The chromophore in these solutions is the 5:6 double bond in the heterocyclic ring which gives rise to an absorption maximum at $260 \mathrm{~nm}$ and it was concluded therefore that the radiation-induced bleaching was due to saturation of this double bond. This was subsequently confirmed by measurement of residual double bonds by bromination with free bromine. In oxygenated thymine solutions, hydroperoxides are formed, and it was concluded therefore that $\mathrm{OH}$ radicals formed during the radiolysis add to the $5: 6$ double bond $[14,15]$. The full reaction sequence is as follows:<smiles>CC1C(=O)N[C@@H](C=O)CC1CO</smiles>

This has since been confirmed in numerous experiments with thymine and other pyrimidines. By comparison with the cis and trans isomers of 5-hydroxy-6-hydroperoxythymine and 6-hydroxy-5hydroperxoythymine, it was shown chromatographically $[16,17]$ that the radiation-induced peroxy compound is a mixture of the cis and trans isomers of the 6-hydroxy derivative. However, for uracil and dimethyluracil where hydroxyhydroperoxides are also produced, there are indications that both the 6-hydroxy and 5-hydroxy radicals are formed by $\mathrm{OH}$ attack in the bases [18].

An interesting application of the aerated thymine system, and of relevance to this monograph, is its use as a reference standard for the measurement of relative rate constants for reactions of $\mathrm{OH}$ with many different solutes [19a, 19b]. The method is based on kinetic analysis of the competition,

$$
\begin{gathered}
\mathrm{OH}+\text { thymine } \rightarrow \text { loss of chromophore } \\
\mathrm{OH}+\text { solute } \rightarrow \text { products, }
\end{gathered}
$$

in which the extent of bleaching of the thymine chromophor is used to measure the relative rate constant ratio $k_{16} / k_{15}$. The application of this kinetic system is discussed more fully in the final chapter together with the normalization procedure used for obtaining absolute values of the rate constants determined by this method.

In the thymine, the site of $\mathrm{OH}$ attack changes gradually with increasing $\mathrm{pH}$ [20]. In solution of

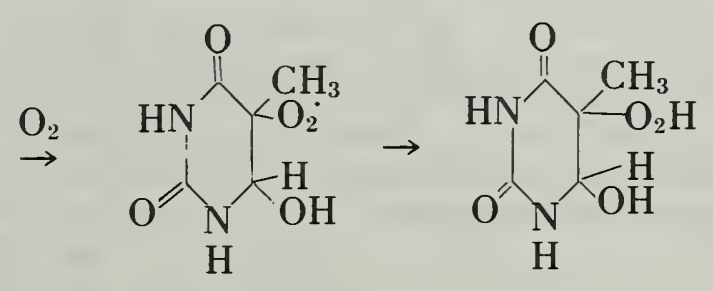

$\mathrm{pH}>9,5$-hydroxymethyluracil is one of the overall products of the oxidation, indicating that under these conditions some attack occurs at the 5-methyl group

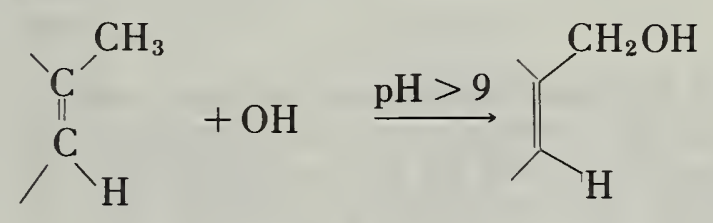

In the presence of cupric ion, the $\mathrm{OH}$ adduct of uracil is mainly oxidized directly to the vicinal glycol derivative [21]

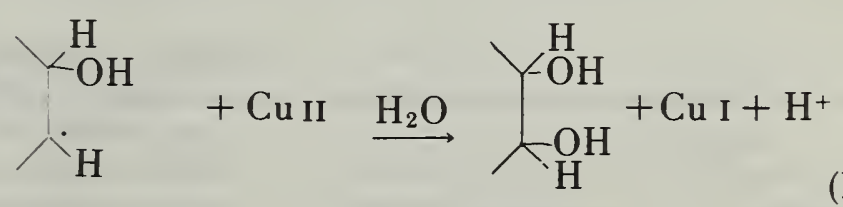

although isobarbituric acid is a minor product of the reaction

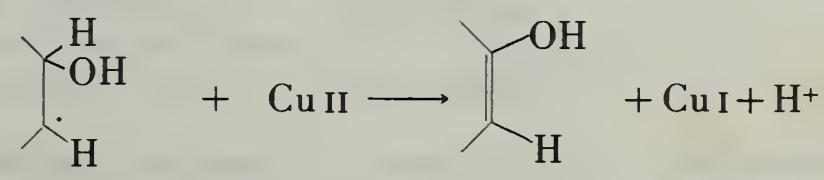

Compared with the pyrimidines, the mechanism of $\mathrm{OH}$-induced oxidation of the purines has received considerabiy less attention. Early radiation chemical 
studies which showed that deamination and ring opening were important in the overall oxidation process were explained on the basis of $\mathrm{OH}$-addition to the 4-5 double bond as the main initiating reaction $[22,23]$<smiles>NC1=NC=NC2N=CNC1N2O</smiles>

However there is some evidence [24] that $\mathrm{OH}$ attack can occur elsewhere in adenine since small yields of 8-hydroxyadenine and 4-5-6-triaminopyrimidine are formed in this system.

Further confirmation that the 4-5 double bond is a major locus of $\mathrm{OH}$ attack in purines was obtained from an analysis of the radiolysis products from several purine bases $[25,26]$. It was argued from conventional purine chemistry that oxidation at the 4-5 position should give, on hydrolysis, 4-5 diketo products. The overall stoichiometry in the case of xanthine is given by the equation:

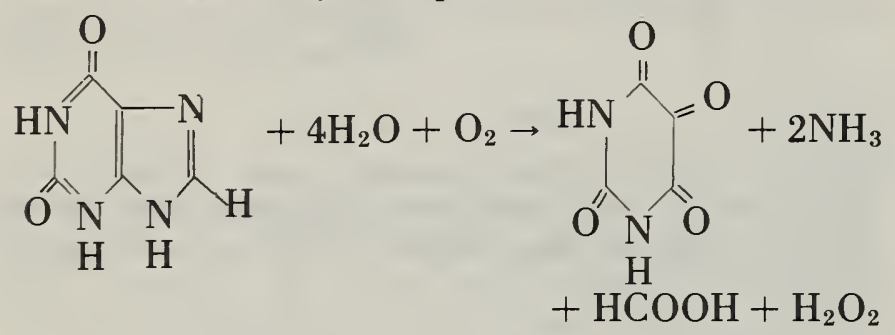

Analysis of irradiated oxygenated xanthine solution showed that alloxan and ammonia were formed in relative yields required by this stoichiometry. For other purines, the degradation products vary although $\mathrm{OH}$ addition at the 4-5 double bond is indicated as the main initiating reaction in each case.

Rate constants for reactions of $\mathrm{OH}$ with free bases, nucleosides, and nucleotides are listed in table 18. In general, the rate constants are near diffusion-limited values and unlike the reactivities with the strongly reducing entity, the hydrated electron, there appears to be little difference between free bases and the sugar phosphate derivatives. Where the data are available, it can be seen that the rate constants measured absolutely by direct observation of the rate of formation of the $\mathrm{OH}$-adduct, agree well with those determined by measurement of the rate of bleaching of the chromophor. This again confirms that the 5-6 double bond in the pyrimidines is the locus of $\mathrm{OH}$ attack. Although there are occasionally very small changes in reactivity with change of $\mathrm{pH}$, it is clear that, also unlike reaction with $e_{\mathrm{aq}}^{-}$, there appears to be little general effect of tautomerism on the rate constants for reaction with $\mathrm{OH}$.

\section{DNA}

Nucleoprotein in aqueous solution is itself fairly resistant to $\mathrm{OH}$ attack [27] which contrasts markedly with the sensitivity of free DNA even when present in solution with equimolar proportions of free protein. This apparent protection of DNA in nucleoprotein is consistent with the proposed structure for this molecule in which the double helix of DNA is enveloped by the protein chains. In aqueous solution therefore, $\mathrm{OH}$ radicals formed in the solvent have restricted access to the DNA core and must react preferentially with the protein sheath.

In solution, free DNA is inactivated by reaction with $\mathrm{OH}$, a process which occurs mainly by attack at the base moieties. However, elimination of free bases also occurs due to $\mathrm{OH}$ attack on the sugar backbone [22]. The relative yield of free base measured after hydrolysis of the irradiated DNA, is about 20 percent of the total base damage. This is as might be expected since, in general, rate constants for reaction of $\mathrm{OH}$ with alcohols and polyhydric compounds (table 19), e.g., ribose, are about an order of magnitude lower than those for addition to pyrimidine and purine bases.

TABLE 14. Sulfur and selenium compounds

\begin{tabular}{|c|c|c|c|c|c|}
\hline Reactant & $k\left(\mathrm{M}^{-1} \mathrm{~s}^{-1}\right)$ & $\mathrm{pH}$ & Ref. & Method & Comments \\
\hline cysteamine & $(1.47 \pm 0.1) \times 10^{10}$ & $1.4-9$ & {$[8]$} & PR comp. with CNS- & Rel. to $k_{\text {thiocyan. }}^{\text {rel. }}=1.1 \times 10^{10}$ \\
\hline cysteine & $\begin{array}{l}1.3 \times 10^{10} \\
(5.1 \pm 0.5) \times 10^{9}\end{array}$ & $\begin{array}{l}1 \\
2\end{array}$ & $\begin{array}{l}{[28]} \\
{[19]}\end{array}$ & $\begin{array}{l}\text { PR comp. with CNS- } \\
\text { S irrad. comp. with thymine }\end{array}$ & $\begin{array}{l}\text { Rel. to } k_{\text {thiocyan. }}^{\text {rel. }}=1.1 \times 10^{10} \\
\text { Rel. to } k_{\mathrm{OH}+\text { thymine }}=4.7 \times 10^{9}\end{array}$ \\
\hline cystine & $(4.8 \pm 0.5) \times 10^{9}$ & 2 & {$[29]$} & $S$ irrad. comp. with thymine & Rel. to $k_{\mathrm{OH}+\text { thymine }}=4.7 \times 10^{9}$ \\
\hline dimethylsulfide & ${ }^{*} 5.2 \times 10^{9}$ & neut. & {$[30]$} & PR product. form. & $\begin{array}{l}\text { Absolute. } \mathrm{N}_{2} \mathrm{O} \text { added. No corr. for } \\
\mathrm{H} \text {-atoms }\end{array}$ \\
\hline dimethylsulfoxide & $7.0 \times 10^{9}$ & neut. & {$[30]$} & PR comp. with CNS- & Rel. to $k_{\text {thiocyan. }}^{\text {rel. }}=1.1 \times 10^{10}$ \\
\hline
\end{tabular}


TABLE 14. Sulfur and selenium compounds-Continued

\begin{tabular}{|c|c|c|c|c|c|}
\hline Reactant & $k\left(\mathrm{M}^{-1} \mathrm{~s}^{-1}\right)$ & $\mathrm{pH}$ & Ref. & Method & Comments \\
\hline glutathione & $1.47 \times 10^{10}$ & 1.0 & {$[28]$} & PR comp. with $\mathrm{CNS}^{-}$ & Rel. to $k_{\text {thiocyan. }}^{\text {rel. }}=1.1 \times 10^{10}$ \\
\hline \multirow{3}{*}{ glycylmethionine } & $(4.0 \pm 0.3) \times 10^{8}$ & 2 & [29] & $\mathrm{S}$ irrad. comp. with thymine & Rel. to $k_{\mathrm{OH}+\text { thymine }}=4.7 \times 10^{9}$ \\
\hline & $(1.1 \pm 0.25) \times 10^{8}$ & 2 & [29] & PR comp. with CNS- & Rel. to $k_{\text {thiocyan. }}^{\text {rel. }}=1.1 \times 10^{10}$ \\
\hline & $(2.2 \pm 0.3) \times 10^{8}$ & 5 & {$[29]$} & PR comp. with $\mathrm{CNS}^{-}$ & Rel. to $k_{\text {thiocyan. }}^{\text {rel. }}=1.1 \times 10^{10}$ \\
\hline \multirow[t]{2}{*}{ hydrogen sulfide } & $1.84 \times 10^{10}$ & 6 & [7] & PR comp. with $\mathrm{CNS}^{-}$ & Rel. to $k_{\text {thiocy an. }}^{\text {rel. }}=1.1 \times 10^{10}$ \\
\hline & $9.0 \times 10^{9}$ & alk. & [7] & PR comp. with CNS- & Rel. to $k_{\text {thiocyan. }}^{\text {rel. }}=1.1 \times 10^{10}$ \\
\hline \multirow[t]{3}{*}{ hydrogen selenide } & $(1.0 \pm 0.3) \times 10^{10}$ & 1.0 & {$[31]$} & $\begin{array}{l}\text { PR comp. with } \mathrm{CNS}^{-} \\
\mathrm{I}^{-} \text {and } \mathrm{Br}^{-}\end{array}$ & $\left\{\begin{array}{c}\text { Mean value calculated three det. } \\
\text { Rel. to } k_{\mathrm{OH}+\mathrm{cNs}-}=6.6 \times 10^{9}\end{array}\right.$ \\
\hline & $5.5 \times 10^{9}$ & $8.5-11.5$ & {$[31]$} & $\begin{array}{l}\mathrm{PR} \text { comp. with } \mathrm{CNS}^{-} \\
\mathrm{I}^{-} \text {and } \mathrm{Br}^{-}\end{array}$ & \\
\hline & & & & & $k_{\mathrm{OH}+\mathrm{Br}-}=5.0 \times 10^{9}$ \\
\hline$t$-butylmercaptan & $(1.8 \pm 0.3) \times 10^{10}$ & 7 & {$[32]$} & PR comp. with $\mathrm{CNS}^{-}$ & Rel. to $k_{\text {thiocyan. }}^{\text {rel. }}=1.1 \times 10^{10}$ \\
\hline \multirow[t]{2}{*}{ methylmercaptan } & $(3.3 \pm 0.5) \times 10^{10}$ & 7 & {$[32]$} & PR comp. with $\mathrm{CNS}^{-}$ & Rel. to $k_{\text {thiocyan. }}^{\text {rel. }}=1.1 \times 10^{10}$ \\
\hline & $(1.0 \pm 0.15) \times 10^{10}$ & 11 & {$[32]$} & PR comp. with CNS- & Rel. to $k_{\text {thiocyan. }}^{\text {rel. }}=1.1 \times 10^{10}$ \\
\hline \multirow[t]{5}{*}{ 2-mercaptoethanol } & $8.5 \times 10^{9}$ & $6-7$ & {$[28]$} & PR comp. with $\mathrm{CNS}^{-}$ & Rel. to $k_{\text {thiocyan. }}^{\text {rel. }}=1.1 \times 10^{10}$ \\
\hline & $(2.7 \pm 0.4) \times 10^{10}$ & 7 & {$[32]$} & PR comp. with $\mathrm{CNS}^{-}$ & Rel. to $k_{\text {thiocyan. }}^{\text {rel. }}=1.1 \times 10^{10}$ \\
\hline & $\dagger(6.1 \pm 0.7) \times 10^{9}$ & 6.5 & {$[33]$} & PR comp. with ferrocyanide & Rel. to $k_{\mathrm{OH}+\text { ferrocyan. }}=9.3 \times 10^{9}$ \\
\hline & $\dagger(4.9 \pm 0.5) \times 10^{9}$ & 6.5 & {$[33]$} & PR comp. with nitrobenzene & Rel. to $k_{\mathrm{OH}+\Phi_{\mathrm{NO}_{2}}}=4.7 \times 10^{9}$ \\
\hline & $(6.7 \pm 0.1) \times 10^{9}$ & 11 & {$[32]$} & PR comp. with $\mathrm{CNS}^{-}$ & Rel. to $k_{\text {thiocyan. }}^{\text {rel. }}=1.1 \times 10^{10}$ \\
\hline \multirow[t]{3}{*}{ methionine } & $(8.2 \pm 0.7) \times 10^{9}$ & $5.5-7$ & {$[29]$} & PR comp. with CNS- & Rel. to $k_{\text {thiocyan. }}^{\text {rel. }}=1.1 \times 10^{10}$ \\
\hline & $8.5 \times 10^{9}$ & $6-7$ & {$[28]$} & PR comp. with CNS- & Rel. to $k_{\text {thiocyan. }}^{\text {rel. }}=1.1 \times 10^{10}$ \\
\hline & $(6.0 \pm 0.5) \times 10^{9}$ & $2-2.8$ & {$[29]$} & $\mathrm{S}$ irrad. comp. with thymine & Rel. to $k_{\mathrm{OH}+\text { thymine }}=4.7 \times 10^{9}$ \\
\hline \multirow[t]{5}{*}{ selenourea } & $* 6.9 \times 10^{9}$ & neut. & {$[11]$} & PR bleaching of solute & Absolute \\
\hline & $* 5.5 \times 10^{9}$ & neut. & {$[11]$} & PR build-up & Absolute \\
\hline & $1.20 \times 10^{10}$ & neut. & {$[11]$} & PR comp. with $\mathrm{CNS}^{-}$ & Rel. to $k_{\text {thiocyan. }}^{\text {rel. }}=1.1 \times 10^{10}$ \\
\hline & $1.14 \times 10^{10}$ & neut. & {$[11]$} & PR comp. with ethanol & Rel. to $k_{\mathrm{OH}+\mathrm{C}_{2} \mathrm{H}_{5} \mathrm{OH}}=1.85 \times 10^{9}$ \\
\hline & $1.17 \times 10^{10}$ & neut. & [11] & PR comp. with methanol & Rel. to $k_{\mathrm{OH}+\mathrm{CH}_{3} \mathrm{OH}}=0.85 \times 10^{9}$ \\
\hline
\end{tabular}

TABLE 15. Amino acids

\begin{tabular}{|c|c|c|c|c|c|}
\hline Reactant & $k\left(M^{-1} \mathrm{~s}^{-1}\right)$ & $\mathrm{pH}$ & Ref. & Method & Comments \\
\hline alanine & $\begin{array}{l}(4.4 \pm 0.2) \times 10^{7} \\
4.65 \times 10^{7} \\
(7.7 \pm 0.6) \times 10^{7} \\
6.6 \times 10^{8}\end{array}$ & $\begin{array}{l}2 \\
6 \\
5.5-6 \\
9.75\end{array}$ & $\begin{array}{l}{[19]} \\
{[35]} \\
{[29]} \\
{[35]}\end{array}$ & $\begin{array}{l}\mathrm{S} \text { irrad. comp. with thymine } \\
\mathrm{S} \text { irrad. comp. with } \\
\text { ferrocyanide } \\
\mathrm{PR} \text { comp. with CNS }{ }^{-} \\
\mathrm{S} \text { irrad. comp. with } \\
\text { ferrocyanide }\end{array}$ & $\begin{array}{l}\text { Rel. to } k_{\mathrm{OH}+\text { thymine }}=4.7 \times 10^{9} \\
\text { Rel. to } k_{\mathrm{OH}+\text { ferrocyan }}=9.3 \times 10^{9} \\
\text { Rel. to } k_{\text {thiocyan. }}^{\text {rel. }}=1.1 \times 10^{10} \\
\text { Rel. to } k_{\mathrm{OH}+\text { ferrocyan. }}=9.3 \times 10^{9}\end{array}$ \\
\hline arginine & $\begin{array}{l}(6.6 \pm 0.6) \times 10^{8} \\
(7.2 \pm 0.5) \times 10^{8} \\
(3.5 \pm 0.3) \times 10^{9}\end{array}$ & $\begin{array}{l}2 \\
2 \\
6.5-7.5\end{array}$ & $\begin{array}{l}{[29]} \\
{[29]} \\
{[29]}\end{array}$ & $\begin{array}{l}\text { PR comp. with CNS- } \\
\text { S irrad. comp. with thymine } \\
\text { PR comp. with CNS- }\end{array}$ & $\begin{array}{l}\text { Rel. to } k_{\text {thiocyan. }}^{\text {rel. }}=1.1 \times 10^{10} \\
\text { Rel. to } k_{\text {OH }+ \text { thymine }}=4.7 \times 10^{9} \\
\text { Rel. to } k_{\text {thiocyan. }}^{\text {rel. }}=1.1 \times 10^{10}\end{array}$ \\
\hline asparagine & $3.1 \times 10^{7}$ & 2 & [19] & $\mathrm{S}$ irrad. comp. with thymine & Rel. to $k_{\mathrm{OH}+\text { thymine }}=4.7 \times 10^{9}$ \\
\hline aspartic acid & $\begin{array}{l}(2.1 \pm 0.2) \times 10^{7} \\
(7.5 \pm 1) \times 10^{7}\end{array}$ & $\begin{array}{l}6.8 \\
2\end{array}$ & $\begin{array}{l}{[29]} \\
{[29]}\end{array}$ & $\begin{array}{l}\mathrm{S} \text { irrad. comp. with thymine } \\
\text { PR comp. with CNS- }\end{array}$ & $\begin{array}{l}\text { Rel. to } k_{\mathrm{OH}+\text { thymine }}=4.7 \times 10^{9} \\
\text { Rel. to } k_{\text {thiocyan. }}^{\text {rel. }}=1.1 \times 10^{10}\end{array}$ \\
\hline
\end{tabular}


TABLE 15. Amino acids-Continued

\begin{tabular}{|c|c|c|c|c|c|}
\hline Reactant & $k\left(M^{-1} \mathrm{~s}^{-1}\right)$ & $\mathrm{pH}$ & Ref. & Method & Comments \\
\hline glutamic acid & $(1.3 \pm 0.1) \times 10^{8}$ & 2 & {$[29]$} & S irrad. comp. with thymine & Rel. to $k_{\mathrm{OH}+\text { thymine }}=4.7 \times 10^{9}$ \\
\hline glutamine & $1.5 \times 10^{8}$ & 2 & {$[19]$} & $S$ irrad. comp. with thymine & Rel. to $k_{\mathrm{OH}+\text { thymine }}=4.7 \times 10^{9}$ \\
\hline \multirow[t]{11}{*}{ glycine } & $1.7 \times 10^{7}$ & 1 & {$[28]$} & PR comp. with CNS ${ }^{-}$ & Rel. to $k_{\text {thiocyan. }}^{\text {rel. }}=1.1 \times 10^{10}$ \\
\hline & $(7.2 \pm 0.3) \times 10^{6}$ & 2.8 & [29] & $S$ irrad. comp. with thymine & Rel. to $k_{\mathrm{OH}+\text { thymine }}=4.7 \times 10^{9}$ \\
\hline & $(1.0 \pm 0.07) \times 10^{7}$ & 2.8 & {$[29]$} & PR comp. with $\mathrm{CNS}^{-}$ & Rel. to $k_{\text {thiocyan. }}^{\text {rel. }}=1.1 \times 10^{10}$ \\
\hline & $4.5 \times 10^{6}$ & 5 & {$[36]$} & S irrad. comp. with PNDA & Rel. to $k_{\mathrm{OH}+\mathrm{C}_{2} \mathrm{H}_{5} \mathrm{OH}}=1.85 \times 10^{9}$ \\
\hline & $(1.7 \pm 0.17) \times 10^{7}$ & 5.8 & {$[29]$} & PR comp. with $\mathrm{CNS}^{-}$ & Rel. to $k_{\text {thiocyan. }}^{\text {rel. }}=1.1 \times 10^{10}$ \\
\hline & $5.9 \times 10^{6}$ & 7 & {$[35]$} & $\begin{array}{l}\mathrm{S} \text { irrad. comp. with } \\
\text { ferrocyanide }\end{array}$ & Rel. to $k_{\mathrm{OH}+\text { ferrocyan }}=9.3 \times 10^{9}$ \\
\hline & $2.7 \times 10^{9}$ & 9.5 & {$[35]$} & $\begin{array}{l}S \text { irrad. comp. with } \\
\text { ferrocyanide }\end{array}$ & Rel. to $k_{\mathrm{OH}+\text { ferrocyan }}=9.3 \times 10^{9}$ \\
\hline & $(1.8 \pm 0.15) \times 10^{9}$ & 9.5 & {$[29]$} & PR comp. with $\mathrm{CNS}^{-}$ & Rel. to $k_{\text {thiocyan. }}^{\text {rel. }}=1.1 \times 10^{10}$ \\
\hline & $2.6 \times 10^{9}$ & 10.5 & {$[37]$} & $S$ irrad. comp. with benzoate & Rel. to $k_{\mathrm{OH}+\text { benzoate }}=5.6 \times 10^{9}$ \\
\hline & $3.8 \times 10^{9}$ & 10.5 & {$[35]$} & $\begin{array}{l}S \text { irrad. comp. with } \\
\text { ferrocyanide }\end{array}$ & Rel. to $k_{\mathrm{OH}+\text { ferrocyan. }}=9.3 \times 10^{9}$ \\
\hline & $2.0 \times 10^{9}$ & 12 & {$[36]$} & S irrad. comp. with PNDA & Rel. to $k_{\mathrm{OH}+\mathrm{C}_{2} \mathrm{H}_{5} \mathrm{OH}}=1.85 \times 10^{9}$ \\
\hline \multirow[t]{2}{*}{ histidine } & $(1.9 \pm 0.15) \times 10^{9}$ & 2 & {$[29]$} & PR comp. with $\mathrm{CNS}^{-}$ & Rel. to $k_{\text {thiocyan. }}^{\text {rel. }}=1.1 \times 10^{10}$ \\
\hline & $(5.0 \pm 0.3) \times 10^{9}$ & $6-7$ & [29] & PR comp. with $\mathrm{CNS}^{-}$ & Rel. to $k_{\text {thiocyan. }}^{\text {rel. }}=1.1 \times 10^{10}$ \\
\hline hydroxyproline & $(3.3 \pm 0.15) \times 10^{8}$ & 2 & {$[29]$} & S irrad. comp. with thymine & Rel. to $k_{\mathrm{OH}+\text { thymine }}=4.7 \times 10^{9}$ \\
\hline isoleucine & $(1.7 \pm 0.1) \times 10^{9}$ & 2 & {$[29]$} & $S$ irrad. comp. with thymine & Rel. to $k_{\mathrm{OH}+\text { thymine }}=4.7 \times 10^{9}$ \\
\hline \multirow[t]{4}{*}{ leucine } & $(1.8 \pm 0.1) \times 10^{9}$ & 2 & [29] & S irrad. comp. with thymine & Rel. to $k_{\mathrm{OH}+\text { thymine }}=4.7 \times 10^{9}$ \\
\hline & $(1.6 \pm 0.1) \times 10^{9}$ & 2 & {$[29]$} & PR comp. with $\mathrm{CNS}^{-}$ & Rel. to $k_{\text {thiocyan. }}^{\text {rel. }}=1.1 \times 10^{10}$ \\
\hline & $(1.6 \pm 0.1) \times 10^{9}$ & 5.5 & {$[29]$} & PR comp. with $\mathrm{CNS}^{-}$ & Rel. to $k_{\text {thiocyan. }}^{\text {rel. }}=1.1 \times 10^{10}$ \\
\hline & $(3.8 \pm 0.5) \times 10^{9}$ & 9.8 & [29] & PR comp. with $\mathrm{CNS}^{-}$ & Rel. to $k_{\text {thiocyan. }}^{\text {rel. }}=1.1 \times 10^{10}$ \\
\hline lysine & $(6.0 \pm 0.5) \times 10^{8}$ & 2 & [29] & S irrad. comp. with thymine & Rel. to $k_{\mathrm{OH}+\text { thymine }}=4.7 \times 10^{9}$ \\
\hline norleucine & $2.8 \times 10^{9}$ & 2 & {$[19]$} & S irrad. comp. with thymine & Rel. to $k_{\mathrm{OH}+\text { thymine }}=4.7 \times 10^{9}$ \\
\hline norvaline & $1.4 \times 10^{9}$ & 2 & {$[19]$} & $S$ irrad. comp. with thymine & Rel. to $k_{\mathrm{OH}+\text { thymine }}=4.7 \times 10^{9}$ \\
\hline ornithine & $1.6 \times 10^{8}$ & 2 & {$[19]$} & $S$ irrad. comp. with thymine & Rel. to $k_{\mathrm{OH}+\text { thymine }}=4.7 \times 10^{9}$ \\
\hline \multirow[t]{6}{*}{ phenylalanine } & $(7.0 \pm 0.3) \times 10^{9}$ & 2 & [29] & $S$ irrad. comp. with thymine & Rel. to $k_{\mathrm{OH}+\text { thymine }}=4.7 \times 10^{9}$ \\
\hline & $(5.7 \pm 0.5) \times 10^{9}$ & 2 & {$[29]$} & PR comp. with CNS- & Rel. to $k_{\text {thiocyan. }}^{\text {rel. }}=1.1 \times 10^{10}$ \\
\hline & $(5.8 \pm 0.5) \times 10^{9}$ & $5.5-6$ & {$[29]$} & PR comp. with $\mathrm{CNS}^{-}$ & Rel. to $k_{\text {thiocyan. }}^{\text {rel. }}=1.1 \times 10^{10}$ \\
\hline & $\dagger 6.0 \times 10^{9}$ & neut. & {$[38]$} & $\begin{array}{l}\text { PR comp. with } \\
\text { ferrocyanide }\end{array}$ & Rel. to $k_{\mathrm{OH}+\text { ferrocyan. }}=9.3 \times 10^{9}$ \\
\hline & $\dagger * 6.6 \times 10^{9}$ & neut. & {$[38]$} & PR product form. & $\begin{array}{l}\text { Absolute. } \mathrm{N}_{2} \mathrm{O} \text { added. No corr. for } \\
\mathrm{H} \text {-addit. }\end{array}$ \\
\hline & $(9.5 \pm 1.5) \times 10^{9}$ & 10.6 & [39] & PR comp. with carbonate & Given rel. to $k_{\mathrm{OH}+\mathrm{CO}_{3}^{2-}}=4.1 \times 10^{8}$ \\
\hline proline & $(2.9 \pm 0.15) \times 10^{8}$ & 2 & {$[29]$} & $S$ irrad. comp. with thymine & Rel. to $k_{\mathrm{OH}+\text { thymine }}=4.7 \times 10^{9}$ \\
\hline \multirow[t]{2}{*}{ serine } & $(2.5 \pm 0.15) \times 10^{8}$ & 2 & {$[29]$} & PR comp. with CNS- & Rel. to $k_{\text {thiocyan. }}^{\text {rel. }}=1.1 \times 10^{10}$ \\
\hline & $(3.2 \pm 0.3) \times 10^{8}$ & $5.5-6$ & [29] & PR comp. with $\mathrm{CNS}^{-}$ & Rel. to $k_{\text {thiocyan. }}^{\text {rel. }}=1.1 \times 10^{10}$ \\
\hline threonine & $(3.6 \pm 0.15) \times 10^{8}$ & 2 & [29] & S irrad. comp. with thymine & Rel. to $k_{\mathrm{OH}+\text { thymine }}=4.7 \times 10^{9}$ \\
\hline
\end{tabular}


TABLE 15. Amino acids-Continued

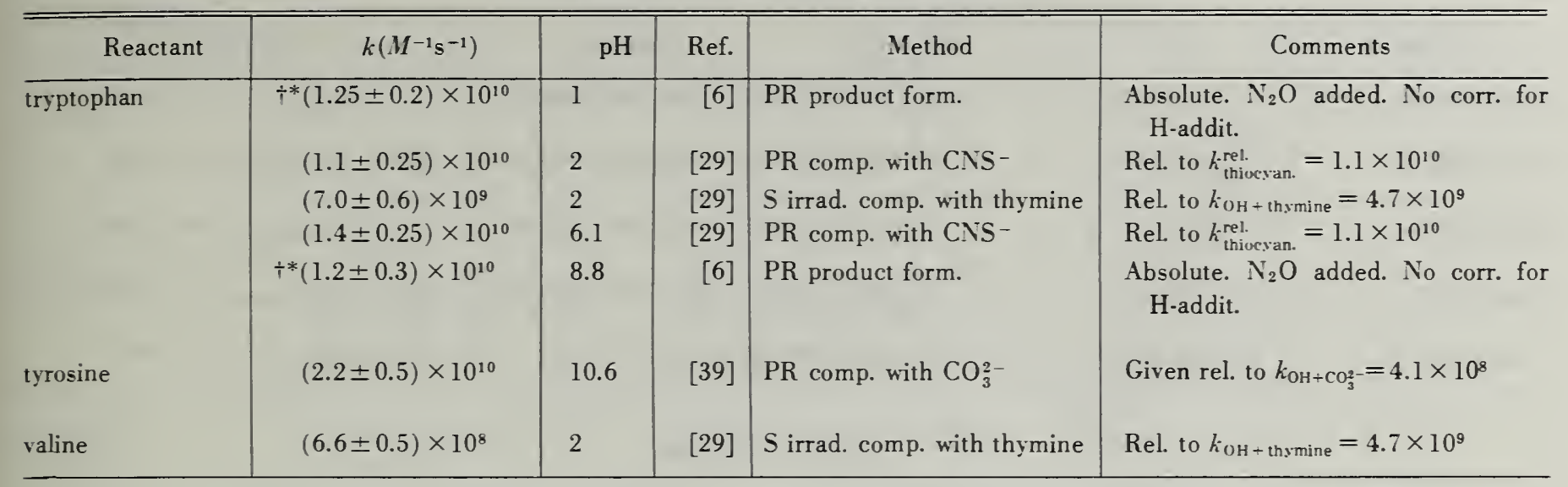

TABLE 16. Simple peptides

\begin{tabular}{|c|c|c|c|c|c|}
\hline Reactant & $k\left(M^{-1} \mathrm{~s}^{-1}\right)$ & $\mathrm{pH}$ & Ref. & Method & Comments \\
\hline acetylalanine & $4.6 \times 10^{8}$ & 9.2 & {$[41]$} & PR comp. with $\mathrm{CNS}^{-}$ & Rel. to $k_{\text {thincyan. }}^{\text {rel. }}=1.1 \times 10^{10}$ \\
\hline acetylglycine & $4.2 \times 10^{8}$ & 8.7 & {$[41]$} & PR comp. with CNS- & Rel. to $k_{\text {thincyan. }}^{\text {rel. }}=1.1 \times 10^{10}$ \\
\hline acetylglycylglycine & $7.8 \times 10^{8}$ & 8.6 & {$[41]$} & PR comp. with CNS- & Rel. to $k_{\text {thiocyan. }}^{\text {rel. }}=1.1 \times 10^{10}$ \\
\hline alanylglycine & $(1.4 \pm 0.8) \times 10^{7}$ & 2 & {$[29]$} & S irrad. comp. with thymine & Rel. to $k_{(\mathrm{OH}+\text { thymine }}=4.7 \times 10^{9}$ \\
\hline \multirow[t]{2}{*}{ glycylalanine } & $(1.7 \pm 0.15) \times 10^{8}$ & 2 & {$[29]$} & S irrad. comp. with thymine & Rel. to $k_{(\mathrm{OH}+\text { thymine }}=4.7 \times 10^{9}$ \\
\hline & $(3.5 \pm 0.3) \times 10^{8}$ & $5.5-6$ & {$[29]$} & PR comp. with $\mathrm{CNS}^{-}$ & Rel. to $k_{\text {thiocsan. }}^{\text {rel. }}=1.1 \times 10^{10}$ \\
\hline \multirow[t]{5}{*}{ glycylglycine } & $\begin{array}{l}(1.2 \pm 0.1) \times 10^{8} \\
(1.6 \pm 0.1) \times 10^{\times}\end{array}$ & $\begin{array}{r}2 \\
2.2\end{array}$ & $\begin{array}{l}{[29]} \\
{[19]}\end{array}$ & $\begin{array}{l}\text { S irrad. comp. with thymine } \\
\text { PR comp. with CNS- }\end{array}$ & $\begin{array}{l}\text { Rel. to } k_{(\mathrm{OH}+\text { thrmine }}=4.7 \times 10^{9} \\
\text { Rel. to } k_{\text {thiocsan. }}^{\text {rel. }}=1.1 \times 10^{10}\end{array}$ \\
\hline & $4.4 \times 10^{8}$ & 4.2 & {$[41]$} & PR comp. with CNS- & Rel. to $k_{\text {thiocyan. }}^{\text {rel. }}=1.1 \times 10^{10}$ \\
\hline & $(2.2 \pm 0.2) \times 10^{8}$ & $5.5-6$ & {$[29]$} & PR comp. with CNS- & Rel. to $k_{\text {thiscyan. }}^{\text {rel. }}=1.1 \times 10^{10}$ \\
\hline & $2.7 \times 10^{8}$ & $6-7$ & {$[28]$} & PR comp. with $\mathrm{CNS}^{-}$ & Rel. to $k_{\text {thiocyan. }}^{\text {rel. }}=1.1 \times 10^{10}$ \\
\hline & $5.2 \times 10^{9}$ & 10.5 & {$[41]$} & PR comp. with $\mathrm{CNS}^{-}$ & Rel. to $k_{\text {thiocyan. }}^{\text {rel. }}=1.1 \times 10^{10}$ \\
\hline \multirow[t]{5}{*}{ glycylglycylglycine } & $\begin{array}{l}(1.4 \pm 0.07) \times 10^{8} \\
(2.4 \pm 0.25) \times 10^{8}\end{array}$ & $\begin{array}{r}2 \\
2.8\end{array}$ & $\begin{array}{l}{[29]} \\
{[29]}\end{array}$ & $\begin{array}{l}\text { S irrad. comp. with thymine } \\
\text { PR comp. with } \mathrm{CNS}^{-}\end{array}$ & $\begin{array}{l}\text { Rel. to } k_{\mathrm{OH}}+\text { thymine } \\
\text { Rel. to } k_{\text {thiocyan. }}^{\text {rel. }}=1.7 \times 10^{9} \\
\text { t. }\end{array}$ \\
\hline & $7.3 \times 10^{8}$ & 5.4 & {$[41]$} & PR comp. with $\mathrm{CNS}^{-}$ & Rel. to $k_{\text {thiocyan. }}^{\text {rel. }}=1.1 \times 10^{10}$ \\
\hline & $(3.3 \pm 0.7) \times 10^{8}$ & $5.5-6.0$ & {$[29]$} & PR comp. with CNS- & Rel. to $k_{\text {thiocyan. }}^{\text {rel. }}=1.1 \times 10^{10}$ \\
\hline & $(1.75 \pm 0.15) \times 10^{9}$ & 8.5 & {$[29]$} & PR comp. with CNS- & Rel. to $h_{\text {thiocyan. }}^{\text {rel. }}=1.1 \times 10^{10}$ \\
\hline & $5.0 \times 10^{9}$ & 10.6 & {$[41]$} & PR comp. with CNS- & Rel. to $k_{\text {thiocyan. }}^{\text {rel. }}=1.1 \times 10^{10}$ \\
\hline \multirow{5}{*}{$\begin{array}{l}\text { glycylglycylglycyl- } \\
\text { glycine }\end{array}$} & $(2.2 \pm 0.6) \times 10^{8}$ & 2 & {$[29]$} & S irrad. comp. with thymine & Rel. to $k_{\mathrm{OH}+\text { thymine }}=4.7 \times 10^{9}$ \\
\hline & $(3.5 \pm 0.3) \times 10^{8}$ & 2.4 & {$[29]$} & PR comp. with $\mathrm{CNS}^{-}$ & Rel. to $k_{\text {thiocyan. }}^{\text {rel. }}=1.1 \times 10^{10}$ \\
\hline & $(4.5 \pm 0.5) \times 10^{8}$ & $5.5-6.0$ & {$[29]$} & PR comp. with $\mathrm{CNS}^{-}$ & Rel. to $k_{\text {thiocyan. }}^{\text {rel. }}=1.1 \times 10^{10}$ \\
\hline & $(1.2 \pm 0.1) \times 10^{9}$ & 7.7 & {$[29]$} & PR comp. with $\mathrm{CNS}^{-}$ & Rel. to $k_{\text {thiocyan. }}^{\text {rel. }}=1.1 \times 10^{10}$ \\
\hline & $(3.0 \pm 0.1) \times 10^{9}$ & 9.5 & {$[29]$} & PR comp. with $\mathrm{CNS}^{-}$ & Rel. to $k_{\text {thiocyan. }}^{\text {rel. }}=1.1 \times 10^{10}$ \\
\hline glycylisoleucine & $(2.7 \pm 0.15) \times 10^{9}$ & 2 & {$[29]$} & $S$ irrad. comp. with thymine & Rel. to $k_{\mathrm{OH}+\text { thymine }}=4.7 \times 10^{9}$ \\
\hline glycylleucine & $(2.3 \pm 0.15) \times 10^{9}$ & 2 & {$[29]$} & $S$ irrad. comp. with thymine & Rel. to $k_{\mathrm{OH}+\text { thymine }}=4.7 \times 10^{9}$ \\
\hline glycylpenylalanine & $(8.2 \pm 0.6) \times 10^{8}$ & 2 & {$[29]$} & S irrad. comp. with thymine & Rel. to $k_{\mathrm{OH}+\text { thymine }}=4.7 \times 10^{9}$ \\
\hline
\end{tabular}


TABLE 16. Simple peptides - Continued

\begin{tabular}{l|r|r|r|l|l}
\hline \hline \multicolumn{1}{c|}{ Reactant } & $k\left(M^{-1} \mathrm{~s}^{-1}\right)$ & $\mathrm{pH}$ & Ref. & Method & Comments \\
\hline glycylproline & $(1.3 \pm 0.1) \times 10^{9}$ & 2 & {$[29]$} & $\mathrm{S}$ irrad. comp. with thymine & Rel. to $k_{\mathrm{OH}+\text { thymine }}=4.7 \times 10^{9}$ \\
glycylserine & $(5.3 \pm 0.3) \times 10^{8}$ & 2 & {$[29]$} & $\mathrm{S}$ irrad. comp. with thymine & Rel. to $k_{\mathrm{OH}+\text { thymine }}=4.7 \times 10^{9}$ \\
glycyltyrosine & $(9.0 \pm 0.6) \times 10^{9}$ & 2 & {$[29]$} & $\mathrm{S}$ irrad. comp. with thymine & Rel. to $k_{\mathrm{OH}+\text { thymine }}=4.7 \times 10^{9}$ \\
glycylvaline & $(1.1 \pm 0.1) \times 10^{9}$ & 2 & {$[29]$} & $\mathrm{S}$ irrad. comp. with thymine & Rel. to $k_{\mathrm{OH}+\text { thymine }}=4.7 \times 10^{9}$ \\
histidylhistidine & $(9.0 \pm 0.3) \times 10^{9}$ & $5.5-6.5$ & {$[29]$} & PR comp. with CNS - & Rel. to $k_{\text {thiocyan. }}^{\text {rel. }}=1.1 \times 10^{10}$ \\
\hline
\end{tabular}

TABLE 17. Enzymes

\begin{tabular}{|c|c|c|c|c|c|}
\hline Reactant & $k\left(M^{-1} \mathrm{~s}^{-1}\right)$ & $\mathrm{pH}$ & Ref. & Method & Comments \\
\hline \multirow{2}{*}{$\begin{array}{l}\text { alcoholdehydro- } \\
\text { genase (yeast) }\end{array}$} & $1.6 \times 10^{11}$ & 9 & {$[42]$} & $S$ irrad. comp. with PNDA & Rel. to $k_{(\mathrm{OH}+\mathrm{P} \times \mathrm{N}) .1}=1.25 \times 10^{10}$ \\
\hline & $2.2 \times 10^{11}$ & neut. & {$[43]$} & PR comp. with nitrobenzene & Rel. to $k_{\left(\mathrm{OH}+\Phi_{\mathrm{N}()_{2}}\right.}=4.7 \times 10^{9}$ \\
\hline catalase & $1.4 \times 10^{11}$ & basic & {$[44]$} & PR comp. with CNS- & Rel. to $k_{\text {thiocyan. }}^{\mathrm{rel}}=1.1 \times 10^{10}$ \\
\hline \multirow[t]{3}{*}{ lysozyme } & $\dagger 4.9 \times 10^{10}$ & neut. & {$[45]$} & PR product form. & $\begin{array}{l}\text { Absolute. } \mathrm{N}_{2} \mathrm{O} \text { added. No corr. for } \\
\mathrm{H} \text {-addit. }\end{array}$ \\
\hline & $5.1 \times 10^{10}$ & neut. & {$[46]$} & PR comp. with $\mathrm{CNS}^{-}$ & Rel. to $k_{\text {thiocyan. }}^{\text {rel. }}=1.1 \times 10^{10}$ \\
\hline & $1.86 \times 10^{10}$ & 9 & {$[42]$} & S irrad. comp. with PNDA & Rel. to $k_{(\mathrm{OH}+\mathrm{P}: \mathrm{XDA}}=1.25 \times 10^{10}$ \\
\hline \multirow[t]{2}{*}{ ribonuclease } & $4.3 \times 10^{10}$ & 6.8 & {$[47]$} & PR comp. with CNS- & Rel. to $k_{\text {thiocyan. }}^{\text {rel. }}=1.1 \times 10^{10}$ \\
\hline & a $8.7 \times 10^{10}$ & 6.8 & {$[47]$} & PR comp. with CNS - & Rel. to $k_{\text {thiocyan. }}^{\text {rel. }}=1.1 \times 10^{10}$ \\
\hline \multirow[t]{2}{*}{ trypsin } & $\dagger(8.2 \pm 0.7) \times 10^{10}$ & 7.1 & {$[48]$} & PR prod. form. & $\begin{array}{l}\text { Absolute. } \mathrm{N}_{2} \mathrm{O} \text { added. No corr. for } \\
\mathrm{H} \text {-addit. }\end{array}$ \\
\hline & $(1.6 \pm 0.1) \times 10^{11}$ & 7.4 & {$[48]$} & PR comp. with glucose & Rel. to $k_{\mathrm{OH}+\text { klucose }}=1.9 \times 10^{9}$ \\
\hline trypsinogen & $(1.6 \pm 0.1) \times 10^{11}$ & 7 & {$[48]$} & PR comp. with glucose & Rel. to $k_{(\mathrm{H}+\text { Hucuse }}=1.9 \times 10^{9}$ \\
\hline
\end{tabular}

$$
{ }^{\mathrm{a}} \mathrm{T}=60^{\circ} \mathrm{C}
$$

TABLE 18. Nucleic acid derivatives

\begin{tabular}{|c|c|c|c|c|c|}
\hline Reactant & $k\left(M^{-1} \mathrm{~s}^{-1}\right)$ & $\mathrm{pH}$ & Ref. & Method & Comments \\
\hline \multirow[t]{4}{*}{ adenine } & $(8.8 \pm 0.8) \times 10^{8}$ & 2 & {$[29]$} & PR comp. with CNS- & Rel. to $k_{\text {thiocyan. }}^{\text {rel. }}=1.1 \times 10^{10}$ \\
\hline & $(3.8 \pm 0.15) \times 10^{9}$ & $5-5.5$ & {$[29]$} & PR comp. with $\mathrm{CNS}^{-}$ & Rel. to $k_{\text {thiocyan. }}^{\text {rel. }}=1.1 \times 10^{10}$ \\
\hline & $(2.8 \pm 0.5) \times 10^{9}$ & 6.5 & [49] & PR comp. with CNS- & Rel. to $k_{\text {thiocyan. }}^{\text {rel. }}=1.1 \times 10^{10}$ \\
\hline & $(5.0 \pm 0.5) \times 10^{9}$ & 7.3 & {$[29]$} & PR comp. with CNS- & Rel. to $k_{\text {thiocyan. }}^{\text {rel. }}=1.1 \times 10^{10}$ \\
\hline \multirow[t]{3}{*}{ adenosine } & $(1.75 \pm 0.15) \times 10^{9}$ & 2 & {$[29]$} & PR comp. with $\mathrm{CNS}^{-}$ & Rel. to $k_{\text {thiocyan. }}^{\text {rel. }}=1.1 \times 10^{10}$ \\
\hline & $(3.8 \pm 0.3) \times 10^{9}$ & 5.2 & {$[29]$} & PR comp. with $\mathrm{CNS}^{-}$ & Rel. to $k_{\text {thiocyan. }}^{\text {rel. }}=1.1 \times 10^{10}$ \\
\hline & $(4.2 \pm 0.4) \times 10^{9}$ & 7.6 & [29] & PR comp. with CNS- & Rel. to $k_{\text {thlocyan. }}^{\text {rel. }}=1.1 \times 10^{10}$ \\
\hline \multirow[t]{3}{*}{ adenosine-5-phosphate } & $(1.25 \pm 0.12) \times 10^{9}$ & 2 & {$[29]$} & PR comp. with $\mathrm{CNS}^{-}$ & Rel. to $k_{\text {thiocyan. }}^{\text {rel. }}=1.1 \times 10^{10}$ \\
\hline & $(3.0 \pm 0.3) \times 10^{9}$ & 5.2 & {$[29]$} & PR comp. with CNS- & Rel. to $k_{\text {thlocyan. }}^{\text {rel. }}=1.1 \times 10^{10}$ \\
\hline & $4.0 \times 10^{9}$ & 9 & {$[42]$} & S irrad. comp. with PNDA & Rel. to $k_{\mathrm{OH}+\mathrm{PNDA}}=1.25 \times 10^{10}$ \\
\hline \multirow[t]{2}{*}{ deoxyadenylic acid } & $(1.37 \pm 0.12) \times 10^{9}$ & 2 & [29] & PR comp. with $\mathrm{CNS}^{-}$ & Rel. to $k_{\text {thlocyan. }}^{\text {rel. }}=1.1 \times 10^{10}$ \\
\hline & $(3.5 \pm 0.3) \times 10^{9}$ & 6.4 & [29] & PR comp. with $\mathrm{CNS}^{-}$ & Rel. to $k_{\text {thlocyan. }}^{\text {rel. }}=1.1 \times 10^{10}$ \\
\hline
\end{tabular}


TABLE 18. Nucleic acid derivatives-Continued

\begin{tabular}{|c|c|c|c|c|c|}
\hline Reactant & $k\left(M^{-1} \mathrm{~s}^{-1}\right)$ & $\mathrm{pH}$ & Ref. & Method & Comments \\
\hline \multirow[t]{3}{*}{ cytosine } & $(3.1 \pm 0.15) \times 10^{9}$ & 2 & [29] & PR comp. with CNS- & Rel. to $k_{\text {thiocyan. }}^{\text {rel. }}=1.1 \times 10^{10}$ \\
\hline & $(4.5 \pm 0.3) \times 10^{9}$ & $5-6$ & [29] & PR comp. with CNS- & Rel. to $k_{\text {thiocyan. }}^{\text {rel. }}=1.1 \times 10^{10}$ \\
\hline & $(4.9 \pm 0.3) \times 10^{9}$ & 7.4 & [29] & PR comp. with $\mathrm{CNS}^{-}$ & Rel. to $k_{\text {thiocyan. }}^{\text {rel. }}=1.1 \times 10^{10}$ \\
\hline \multirow[t]{3}{*}{ cytidine } & $(3.3 \pm 0.3) \times 10^{9}$ & 2 & {$[29]$} & PR comp. with CNS- & Rel. to $k_{\text {thioceran. }}^{\text {rel. }}=1.1 \times 10^{10}$ \\
\hline & $(4.9 \pm 0.5) \times 10^{9}$ & 5.2 & {$[29]$} & PR comp. with $\mathrm{CNS}^{-}$ & Rel. to $k_{\text {thiocyan. }}^{\text {rel. }}=1.1 \times 10^{10}$ \\
\hline & $(4.6 \pm 0.5) \times 10^{9}$ & 7.2 & [29] & PR comp. with $\mathrm{CNS}^{-}$ & Rel. to $k_{\text {thiocyan. }}^{\text {rel. }}=1.1 \times 10^{10}$ \\
\hline \multirow{2}{*}{$\begin{array}{l}\text { cystosine-5- } \\
\text { phosphate }\end{array}$} & $(2.5 \pm 0.25) \times 10^{9}$ & 2 & [29] & PR comp. with CNS- & Rel. to $k_{\text {thiocyan. }}^{\text {rel. }}=1.1 \times 10^{10}$ \\
\hline & $(4.4 \pm 0.5) \times 10^{9}$ & 7.4 & [29] & PR comp. with CNS- & Rel. to $k_{\text {thiucyan. }}^{\text {rel. }}=1.1 \times 10^{10}$ \\
\hline \multirow[t]{3}{*}{ deoxycytidylic acid } & $(3.0 \pm 0.15) \times 10^{9}$ & 2 & [29] & PR comp. with $\mathrm{CNS}^{-}$ & Rel. to $k_{\text {thiucyan. }}^{\text {rel. }}=1.1 \times 10^{10}$ \\
\hline & $(3.8 \pm 0.3) \times 10^{9}$ & 4.3 & [29] & PR comp. with $\mathrm{CNS}^{-}$ & Rel. to $k_{\text {thiucyan. }}^{\text {rel. }}=1.1 \times 10^{10}$ \\
\hline & $(5.0 \pm 0.3) \times 10^{9}$ & 6.7 & {$[29]$} & PR comp. with CNS- & Rel. to $k_{\text {thiucyan. }}^{\text {rel. }}=1.1 \times 10^{10}$ \\
\hline guanosine & $7.6 \times 10^{9}$ & 9 & {$[42]$} & S irrad. comp. with PNDA & Rel. to $k_{0 \mathrm{H}+\mathrm{P} \times \mathrm{NA} A}=1.25 \times 10^{10}$ \\
\hline \multirow[t]{2}{*}{ deoxyguanylic acid } & $(4.7 \pm 0.5) \times 10^{9}$ & 2 & {$[29]$} & PR comp. with CNS- & Rel. to $k_{\text {thiucyan. }}^{\text {rel. }}=1.1 \times 10^{10}$ \\
\hline & $(6.8 \pm 0.5) \times 10^{9}$ & $6.5-7.0$ & [29] & PR comp. with CNS- & Rel. to $k_{\text {thiocyan. }}^{\text {rel. }}=1.1 \times 10^{10}$ \\
\hline orotic acid & $5.1 \times 10^{9}$ & neut. & {$[54]$} & PR comp. with ferrocyanide & Rel. to $k_{0 \mathrm{H}+\text { ferrocyan }}:=9.3 \times 10^{9}$ \\
\hline isoorotic acid & $3.9 \times 10^{9}$ & neut. & {$[54]$} & PR comp. with ferrocyanide & Rel. to $k_{0 \mathrm{H}+\text { ferrocyan. }}=9.3 \times 10^{9}$ \\
\hline dihydroorotic acid & $2.9 \times 10^{9}$ & neut. & {$[54]$} & PR comp. with ferrocyanide & Rel. to $k_{0 \mathrm{H}+\text { ferrucyan }}=9.3 \times 10^{9}$ \\
\hline orotidine & $3.9 \times 10^{9}$ & neut. & [54] & PR comp. with ferrocyanide & Rel. to $k_{011+\text { ferrucsan. }}=9.3 \times 10^{9}$ \\
\hline \multirow[t]{15}{*}{ thymine } & $(3.7 \pm 0.2) \times 10^{9}$ & $0.7-7.0$ & {$[50]$} & S irrad. loss of chromophor & Rel. to ethanol taking \\
\hline & $5.2 \times 10^{9}$ & 1 & {$[28]$} & PR comp. with CNS- & $\begin{aligned} k_{0 \mathrm{H}}+\mathrm{c}_{2} 1_{5} \mathrm{OH} & =1.85 \times 10^{9} \\
\text { Rel. to } k^{\text {rel. }} & =1.1 \times 10^{10}\end{aligned}$ \\
\hline & $(5.2 \pm 0.2) \times 10^{9}$ & 2 & [29] & PR comp. with CNS- & Rel. to $k^{\text {rel. }}=1.1 \times 10^{10}$ \\
\hline & $\begin{array}{l}(7.8 \pm 1.0) \times 10^{9} \\
(5.0 \pm 0.2) \times 10^{9}\end{array}$ & $\begin{array}{l}2 \\
5-5.5\end{array}$ & $\begin{array}{l}{[19]} \\
{[29]}\end{array}$ & $\begin{array}{l}\text { S irrad. loss of chromophor } \\
\text { PR comp. with CNS- }\end{array}$ & $\begin{array}{l}\text { Rel. to } k_{O H+C_{6} H_{6}}=7.8 \times 10^{9} \\
\text { Rel. to } k_{\text {thiucyan. }}^{\text {rel. }}=1.1 \times 10^{10}\end{array}$ \\
\hline & $(5.3 \pm 0.2) \times 10^{9}$ & 7.2 & [29] & PR comp. with $\mathrm{CNS}^{-}$ & Rel. to $k_{\text {thiocyan. }}^{\text {rrl. }}=1.1 \times 10^{10}$ \\
\hline & ${ }^{*} 7.4 \times 10^{9}$ & 7 & [51] & PR product form. & $\begin{array}{l}\text { Absolute. } \mathrm{N}_{2} \mathrm{O} \text { added. No corr. for } \\
\mathrm{H} \text {-addit. }\end{array}$ \\
\hline & $4.9 \times 10^{9}$ & 7 & [52] & S irrad. loss of chromophor & $\begin{array}{l}\text { Comp. with methanol and ethanol. } \\
\text { Rel. to } k_{\mathrm{OH}+\mathrm{C}_{2} \mathrm{H}_{\mathrm{s}} \mathrm{OH}}=1.85 \times 10^{9}\end{array}$ \\
\hline & $\dagger 4.7 \times 10^{9}$ & neut. & {$[38]$} & PR comp. with ferrocyanide & Rel. to $k_{\mathrm{OH}+\text { ferrocyan. }}=9.3 \times 10^{9}$ \\
\hline & $\dagger * 5.1 \times 10^{9}$ & neut. & [38] & PR bleaching chromophor & Absolute. $\mathrm{N}_{2} \mathrm{O}$ and $\mathrm{O}_{2}$ added \\
\hline & $(7.6 \pm 1.1) \times 10^{9}$ & neut. & [53] & PR comp. with $\mathrm{CNS}^{-}$ & 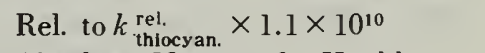 \\
\hline & $*(7-4 \pm 0.5) \times 10^{9}$ & neut. & [53] & PR bleaching of chromophor & Absolute. No corr. for $\mathrm{H}$-addit. \\
\hline & ${ }^{*}(4.6 \pm 0.3) \times 10^{9}$ & neut. & {$[53]$} & PR product form. & Absolute. No corr. for $\mathrm{H}$-addit. \\
\hline & $\begin{array}{r}6.2 \times 10^{9} \\
\dagger^{*} 3.9 \times 10^{9}\end{array}$ & & $\begin{array}{l}{[42]} \\
{[51]}\end{array}$ & S irrad. comp. with PNDA & $\begin{array}{l}\text { Rel. to } k_{\mathrm{OH}+\mathrm{PNDA}}=1.25 \times 10^{10} \\
\text { Absolute. } \mathrm{N}_{2} \mathrm{O} \text { added. No corr. for }\end{array}$ \\
\hline & $\dagger * 3.9 \times 10^{9}$ & & {$[1]$} & PR product form. & $\begin{array}{l}\text { Absolute. } \mathrm{N}_{2} \mathrm{O} \text { adaea. No corr. For } \\
\mathrm{H} \text {-addit. }\end{array}$ \\
\hline & $\dagger^{*} 1.1 \times 10^{9}$ & 12.4 & [51] & PR product form. & $\begin{array}{l}\text { Absolute. } \mathrm{N}_{2} \mathrm{O} \text { added. No corr. for } \\
\mathrm{H} \text {-addit. }\end{array}$ \\
\hline
\end{tabular}


TABLE 18. Nucleic acid derivatives-Continued

\begin{tabular}{|c|c|c|c|c|}
\hline Reactant & $k\left(M^{-1} \mathrm{~s}^{-1}\right)$ & $\mathrm{pH}$ & Ref. & Method \\
\hline dihydrothymine & $\begin{array}{l}(4.7 \pm 0.5) \times 10^{9} \\
\dagger^{*} 2.2 \times 10^{9} \\
\dagger^{*} 2.2 \times 10^{9} \\
{ }^{*} 4 \times 10^{8}\end{array}$ & $\begin{array}{l}\text { neut. } \\
\text { neut. } \\
\text { neut. } \\
12.4\end{array}$ & $\begin{array}{l}{[53]} \\
{[53]} \\
{[51]} \\
{[51]}\end{array}$ & $\begin{array}{l}\text { PR comp. with CNS- } \\
\text { PRproduct from. } \\
\text { PR product form. } \\
\text { PR product form. }\end{array}$ \\
\hline thymidine & $\begin{array}{l}(4.6 \pm 0.5) \times 10^{9} \\
(5.0 \pm 0.5) \times 10^{9} \\
(4.6 \pm 0.5) \times 10^{9} \\
\dagger^{*} 4.7 \times 10^{9} \\
\dagger^{*} 2.1 \times 10^{9}\end{array}$ & $\begin{array}{l}2 \\
5 \\
7.4 \\
7 \\
\\
12.4\end{array}$ & $\begin{array}{l}{[29]} \\
{[29]} \\
{[29]} \\
{[51]} \\
{[51]}\end{array}$ & $\begin{array}{l}\text { PR comp. with CNS- } \\
\text { PR comp. with } \mathrm{CNS}^{-} \\
\text {PR comp. with } \mathrm{CNS}^{-} \\
\text {PR product form. } \\
\text { PR product form. }\end{array}$ \\
\hline $\begin{array}{l}\text { thymicylic acid } \\
\text { (amm. salt) }\end{array}$ & $\begin{array}{l}(4.3 \pm 0.5) \times 10^{9} \\
(5.3 \pm 0.5) \times 10^{9}\end{array}$ & $\begin{array}{l}2 \\
6.5-7.0\end{array}$ & $\begin{array}{l}{[29]} \\
{[29]}\end{array}$ & $\begin{array}{l}\text { PR comp. with } \mathrm{CNS}^{-} \\
\text {PR comp. with } \mathrm{CNS}^{-}\end{array}$ \\
\hline uracil & $\begin{aligned} &(4.8 \pm 0.5) \times 10^{9} \\
&(5.2 \pm 0.7) \times 10^{9} \\
&(7.3 \pm 0.9) \times 10^{9} \\
& \dagger^{*}(7.4 \pm 1.0) \times 10^{9} \\
&(7.3 \pm 0.9) \times 10^{9} \\
& \dagger^{*}(6.0 \pm 0.3) \times 10^{9} \\
& t^{*}(6.5 \pm 0.7) \times 10^{9} \\
&(5.3 \pm 0.5) \times 10^{9} \\
& 6.8 \times 10^{9}\end{aligned}$ & $\begin{array}{l}2 \\
5 \\
6.5 \\
7 \\
\text { neut. } \\
\text { neut. } \\
\text { neut. } \\
7.3 \\
9\end{array}$ & $\begin{array}{l}{[29]} \\
{[29]} \\
{[49]} \\
{[49]} \\
{[53]} \\
{[53]} \\
{[53]} \\
{[29]} \\
{[42]}\end{array}$ & $\begin{array}{l}\text { PR comp. with CNS- } \\
\text { PR comp. with CNS- } \\
\text { PR comp. with } \mathrm{CNS}^{-} \\
\text {PR loss of chromophor } \\
\text { PR comp. with CNS } \\
\text { PR loss of chromophor } \\
\text { PR product form. } \\
\text { PR comp. with CNS- } \\
\text { S irrad. comp. with PNDA }\end{array}$ \\
\hline 5-bromouracil & $\begin{array}{r}4.3 \times 10^{9} \\
\dagger^{*} 3.6 \times 10^{9}\end{array}$ & $\begin{array}{l}9 \\
7\end{array}$ & $\begin{array}{l}{[42]} \\
{[40]}\end{array}$ & $\begin{array}{l}\text { S irrad. comp. with PNDA } \\
\text { PR prod. form. }\end{array}$ \\
\hline dihydrouracil & $(1.2 \pm 0.15) \times 10^{9}$ & neut. & {$[53]$} & PR comp. with CNS- \\
\hline uridine & $\begin{array}{r}(4.2 \pm 0.6) \times 10^{9} \\
t^{*}(6.0 \pm 0.3) \times 10^{9} \\
t^{*}(6.5 \pm 0.7) \times 10^{9} \\
(4.3 \pm 0.6) \times 10^{9}\end{array}$ & $\begin{array}{l}\text { neut. } \\
\text { neut. } \\
\text { neut. } \\
6.5\end{array}$ & $\begin{array}{l}{[53]} \\
{[53]} \\
{[53]} \\
{[49]}\end{array}$ & $\begin{array}{l}\text { PR comp. with CNS- } \\
\text { PR loss of chromophor } \\
\text { PR product form. } \\
\text { PR comp. with CNS- }\end{array}$ \\
\hline $\begin{array}{l}\text { uridine mono- } \\
\text { phosphate (mixed) }\end{array}$ & $\begin{array}{r}(5.1 \pm 0.8) \times 10^{9} \\
(5.1 \pm 0.7) \times 10^{9} \\
\dagger^{*}(4.6 \pm 0.3) \times 10^{9} \\
\dagger^{*}(4.0 \pm 0.4) \times 10^{9}\end{array}$ & $\begin{array}{l}6.5 \\
\text { neut. } \\
\text { neut. } \\
\text { neut. }\end{array}$ & $\begin{array}{l}{[49]} \\
{[53]} \\
{[53]} \\
{[53]}\end{array}$ & $\begin{array}{l}\text { PR comp. with CNS- } \\
\text { PR comp. with CNS- } \\
\text { PR loss of chromophor } \\
\text { PR product form. }\end{array}$ \\
\hline $\begin{array}{l}\text { uridylyl } 3^{\prime} \rightarrow 5^{\prime} \\
\text { uridine }(\mathrm{UpU})\end{array}$ & $\begin{array}{r}(5.3 \pm 0.6) \times 10^{9} \\
\dagger^{*}(3.8 \pm 0.2) \times 10^{9}\end{array}$ & $\begin{array}{l}\text { neut. } \\
\text { neut. }\end{array}$ & $\begin{array}{l}{[53]} \\
{[53]}\end{array}$ & $\begin{array}{l}\text { PR comp. with CNS- } \\
\text { PR loss of chromophor }\end{array}$ \\
\hline oligouridylic acid & $\begin{array}{r}(4.0 \pm 0.6) \times 10^{9} \\
\dagger^{*}(4.3 \pm 0.2) \times 10^{9}\end{array}$ & $\begin{array}{l}\text { neut. } \\
\text { neut. }\end{array}$ & $\begin{array}{l}{[53]} \\
{[53]}\end{array}$ & $\begin{array}{l}\text { PR comp. with CNS- } \\
\text { PR loss of chromophor }\end{array}$ \\
\hline polyuridylic acid & $(1.5 \pm 0.15) \times 10^{9}$ & neut. & {$[53]$} & PR comp. with $\mathrm{CNS}^{-}$ \\
\hline
\end{tabular}

Comments

Rel. to $k_{\text {thlocyan. }}^{\text {rel. }}=1.1 \times 10^{10}$

Absolute. No corr. for $\mathrm{H}$-addit.

Absolute. $\mathrm{N}_{2} \mathrm{O}$ added. No corr. for $\mathrm{H}$-addit.

Absolute. $\mathrm{N}_{2} \mathrm{O}$ added. No corr. for $\mathrm{H}$-addit.

Rel. to $k_{\text {thlocyan. }}^{\text {rel. }}=1.1 \times 10^{10}$

Rel. to $k_{\text {thiocyan. }}^{\text {relocyan. }}=1.1 \times 10^{10}$

Rel. to $k_{\text {thiocyan. }}^{\text {rel. }}=1.1 \times 10^{10}$

Absolute. $\mathrm{N}_{2} \mathrm{O}$ added. No corr. for $\mathrm{H}$-addit.

Absolute. $\mathrm{N}_{2} \mathrm{O}$ added. No corr. for $\mathrm{H}$-addit.

Rel. to $k_{\text {thiocyan. }}^{\text {rel. }}=1.1 \times 10^{10}$

Rel. to $k_{\text {thiocyan. }}^{\text {rel. }}=1.1 \times 10^{10}$

Rel. to $k_{\text {thiocyan. }}^{\text {rel. }}=1.1 \times 10^{10}$

Rel. to $k_{\text {thiocyan. }}^{\text {rel. }}=1.1 \times 10^{10}$

Rel. to $k_{\text {thiocyan. }}^{\text {rel. }}=1.1 \times 10^{10}$ Absolute. No corr. for $\mathrm{H}$-addit.

Rel. to $k_{\text {thiocyan. }}^{\text {rel. }}=1.1 \times 10^{10}$ Absolute. No corr. for $\mathrm{H}$-addit. Absolute. No corr. for $\mathrm{H}$-addit.

Rel. to $k_{\text {thiocyan. }}^{\text {rel. }}=1.1 \times 10^{10}$

Rel. to $k_{\mathrm{OH}+\mathrm{PNDA}}=1.25 \times 10^{10}$

Rel. to $k_{\mathrm{OH}+\mathrm{PNDA}}=1.25 \times 10^{10}$

Absolute. $\mathrm{N}_{2} \mathrm{O}$ added. No corr. for $\mathrm{H}$-addit.

Rel. to $k_{\text {thiocyan. }}^{\text {rel. }}=1.1 \times 10^{10}$

Rel. to $k_{\text {thiocyan. }}^{\text {rel. }}=1.1 \times 10^{10}$ Absolute. No corr. for $\mathrm{H}$-addit. Absolute. No corr. for $\mathrm{H}$-addit. Rel. to $k_{\text {thiocyan. }}^{\text {rel. }}=1-1 \times 10^{10}$

Rel. to $k_{\text {thiocyan. }}^{\text {rel. }}=1.1 \times 10^{10}$

Rel. to $k_{\text {thlocyan. }}^{\text {rel. }}=1.1 \times 10^{10}$ Absolute. No corr. for $\mathrm{H}$-addit. Absolute. No corr. for $\mathrm{H}$-addit.

Rel. to $k_{\text {thiocyan. }}^{\text {rel. }}=1.1 \times 10^{10}$

Absolute. No corr. for $\mathbf{H}$-addit. (calc. per unit base)

Rel. to $k_{\text {thiocyan. }}^{\text {rel. }}=1.1 \times 10^{10}$ Absolute. No corr. for $\mathrm{H}$-addit. (calc. per unit base)

Rel. to $k_{\text {thlocyan. }}^{\text {rel. }}=1.1 \times 10^{10}$ 
TABLE 18. Nucleic acid derivatives-Continued

\begin{tabular}{l|l|l|l|l|l}
\hline \multicolumn{1}{c|}{ Reactant } & $k\left(M^{-1} \mathrm{~s}^{-1}\right)$ & $\mathrm{pH}$ & Ref. & Method & Comments \\
\hline DNA & $* 6 \times 10^{8}$ & 7 & {$[51]$} & PR product form. & $\begin{array}{c}\text { Absolute. } \mathrm{N}_{2} \mathrm{O} \text { added. No corr. for } \\
\text { H-addit. Based on mean nucleotide } \\
\text { mol. wt. of } 350 \\
\text { Absolute. } \mathrm{N}_{2} \mathrm{O} \text { added. No corr. for } \\
\mathrm{H} \text {-addit. Based on mean nucleotide } \\
\text { mol. wt. of } 350 \\
\text { Rel. to } k_{\text {OH+PNDA }}=1.25 \times 10^{10} \\
\left.\text { (mol. wt. }=5 \times 10^{6}\right) \\
\text { Absolute. } \mathrm{N}_{2} \mathrm{O} \text { added. No corr. for } \\
\left.\mathrm{H} \text {-addit. (mol. wt. }=5 \times 10^{6}\right)\end{array}$ \\
\hline
\end{tabular}

TABLE 19. Carbohydrates and related compounds

\begin{tabular}{|c|c|c|c|c|c|}
\hline Reactant & $k\left(M^{-1} \mathrm{~s}^{-1}\right)$ & $\mathrm{pH}$ & Ref. & Method & Comments \\
\hline ascorbic acid & $1.20 \times 10^{10}$ & 1 & {$[28]$} & PR comp. with CNS- & Rel. to $k_{\text {thiocyan. }}^{\text {rel. }}=1.1 \times 10^{10}$ \\
\hline $\begin{array}{l}\text { 2-acetamido-2-deoxy- } \\
D \text {-glucose }\end{array}$ & $3.07 \times 10^{9}$ & & {$[55]$} & PR comp. with $\mathrm{CNS}^{-}$ & Rel. to $k_{\text {thiocyan. }}^{\text {rel. }}=1.1 \times 10^{10}$ \\
\hline $\begin{array}{l}\text { 2-acetamido-2-deoxy- } \\
D \text {-galactose }\end{array}$ & $1.62 \times 10^{9}$ & & {$[55]$} & PR comp. with CNS- & Rel. to $k_{\text {thiocyan. }}^{\text {rel. }}=1.1 \times 10^{10}$ \\
\hline$N$-acetylglucoseamine & $3.07 \times 10^{9}$ & & {$[56]$} & PR comp. with CNS- & Rel. to $k_{\text {thiocyan. }}^{\text {rel }}=1.1 \times 10^{10}$ \\
\hline $\begin{array}{l}\text { 2-amino-2-deoxy- } D \text { - } \\
\text { galactose }(\mathrm{HCl})\end{array}$ & $1.77 \times 10^{9}$ & & {$[55]$} & PR comp. with CNS- & Rel. to $k_{\text {thiocyan. }}^{\text {rèl. }}=1.1 \times \overline{10} 0^{10}$ \\
\hline $\begin{array}{l}\text { chondroitin-4- } \\
\text { sulfate I }\end{array}$ & $8.0 \times 10^{8}$ & & {$[55]$} & PR comp. with CNS- & $\begin{array}{l}\text { Rel. to } k_{\text {thiocyan. }}^{\text {rel. }}=1.1 \times 10^{10} \\
\text { Conc. }=\text { mol. equiv./liter } \\
\text { (1. equiv. = average mol. wt. of hexose } \\
\text { unit) }\end{array}$ \\
\hline $\begin{array}{l}\text { chondroitin-6- } \\
\text { sulfate I }\end{array}$ & $6.8 \times 10^{8}$ & & {$[55]$} & PR comp. with $\mathrm{CNS}^{-}$ & $\begin{array}{l}\text { Rel. to } k_{\text {thiocyan. }}^{\text {rel. }}=1.1 \times 10^{10} \\
\text { Conc. }=\text { mol. equiv./liter } \\
\text { (l. equiv. }=\text { average mol. wt. of } \\
\text { hexose unit) }\end{array}$ \\
\hline$N \cdot$ desulfated heparin & $8.0 \times 10^{8}$ & & {$[55]$} & PR comp. with CNS- & $\begin{array}{l}\text { Rel. to } k_{\text {thiocyan. }}^{\text {rel. }}=1.1 \times 10^{10} \\
\text { Conc. }=\text { mol. equiv. } / \text { liter } \\
\text { ( } 1 \text { equiv. }=\text { average mol. wt. of } \\
\text { hexose unit) }\end{array}$ \\
\hline $\begin{array}{l}\text { 2-deoxy-2-sulfo- } \\
\text { amino- } D \text {-glucose }\end{array}$ & $2.12 \times 10^{9}$ & & {$[55]$} & PR comp. with CNS- & Rel. to $k_{\text {thiocyan. }}^{\text {rel. }}=1.1 \times 10^{10}$ \\
\hline erythrytol & $2.0 \times 10^{9}$ & 9 & {$[36]$} & S irrad. comp. with PNDA & Rel. to $k_{\mathrm{OH}+\mathrm{C}_{2} \mathrm{H}_{3} \mathrm{OH}}=1.85 \times 10^{9}$ \\
\hline glucose & $\begin{array}{l}1 \times 10^{10} \\
1.9 \times 10^{9}\end{array}$ & 2 & $\begin{array}{l}{[57]} \\
{[19]}\end{array}$ & $\begin{array}{l}\text { PR comp. with } \mathrm{I}^{-} \\
\mathrm{S} \text { irrad. comp. with thymine }\end{array}$ & $\begin{array}{l}\text { Rel. to } k_{\mathrm{OH}+\mathrm{I}^{-}}=1.0 \times 10^{10} \\
\text { Rel. to } k_{\mathrm{OH}+\text { thymine }}=4.7 \times 10^{9}\end{array}$ \\
\hline glucuronic acid & $3.09 \times 10^{9}$ & & {$[56]$} & PR comp. with $\mathrm{CNS}^{-}$ & Rel. to $k_{\text {thiocyan. }}^{\text {rel. }}=1.1 \times 10^{10}$ \\
\hline$D$-glucuronate $(\mathrm{Na})$ & $3.09 \times 10^{9}$ & & {$[55]$} & PR comp. with CNS- & Rel. to $k_{\text {thiocyan. }}^{\text {rei. }}=1.1 \times 10^{10}$ \\
\hline heparin & $3.7 \times 10^{8}$ & & {$[56]$} & PR comp. with $\mathrm{CNS}^{-}$ & $\begin{array}{l}\text { Rel. to } k_{\text {thiocyan. }}^{\text {rel. }}=1.1 \times 10^{10} \\
\text { Conc. }=\text { mol. equiv. } / \text { liter } \\
\text { ( } 1 \text { equiv. }=\text { average mol. wt. of } \\
\text { hexose unit.) }\end{array}$ \\
\hline
\end{tabular}


TABLE 19. Carbohydrates and related compounds-Continued

\begin{tabular}{|c|c|c|c|c|c|}
\hline Reactant & $k\left(M^{-1} \mathrm{~s}^{-1}\right)$ & $\mathrm{pH}$ & Ref. & Method & Comments \\
\hline hyaluronic acid & $\begin{array}{l}6.7 \times 10^{8} \\
(1.34 \pm 0.07) \times 10^{9}\end{array}$ & & {$[58]$} & PR comp. with CNS- & $\begin{array}{l}\text { Rel. to } k_{\text {thiocyan. }}^{\text {rel. }}=1.1 \times 10^{10} \\
\text { Conc. }=\text { mol. equiv./liter } \\
\text { (l equiv. }=\text { average mol. wt. of } \\
\text { hexose unit.) } \\
\text { Rel. to } k_{\text {thiocyan. }}^{\text {rel. }}=1.1 \times 10^{10} \\
\text { Conc. }=\text { mol. equiv./liter } \\
\text { ( } 1 \text { equiv. }=\text { average mol. wt. of } \\
\text { hexose unit.) }\end{array}$ \\
\hline $\begin{array}{l}\text { hyaluronic acid } \\
\text { (sulfated) }\end{array}$ & $6.0 \times 10^{8}$ & & {$[55]$} & PR comp. with $\mathrm{CNS}^{-}$ & $\begin{array}{l}\text { Rel. to } k_{\text {thiocyan. }}^{\text {rel. }}=1.1 \times 10^{10} \\
\text { Conc. }=\text { mo. equiv./liter } \\
(1 \text { equiv. }=\text { average mol. wt. of } \\
\text { hexose unit. })\end{array}$ \\
\hline keratan sulfate & $7.8 \times 10^{9}$ & & {$[59]$} & PR comp. with $\mathrm{CNS}^{-}$ & $\begin{array}{l}\text { Rel. to } k_{\text {thiocyan. }}^{\text {rel. }}=1.1 \times 10^{10} \\
\text { Conc. }=\text { mol. equiv./liter } \\
\text { ( } 1 \text { equiv. }=\text { average mol. wt. of } \\
\text { hexose unit.) }\end{array}$ \\
\hline pentaerythrytol & $3.2 \times 10^{9}$ & 9 & {$[36]$} & S irrad. comp. with PNDA & Rel. to $k_{\mathrm{OH}+\mathrm{C}_{2} \mathrm{H}_{5} \mathrm{OH}}=1.85 \times 10^{9}$ \\
\hline ribose & $2.1 \times 10^{9}$ & 9 & {$[42]$} & $S$ irrad. comp. with PNDA & Rel. to $k_{\mathrm{OH}+\mathrm{PNDA}}=1.25 \times 10^{10}$ \\
\hline sucrose & $(2.5 \pm 0.3) \times 10^{9}$ & 2 & {$[19]$} & $S$ irrad. comp. with thymine & Rel. to $k_{\mathrm{OH}+\text { thymine }}=4.7 \times 10^{9}$ \\
\hline
\end{tabular}

TABLE 20. Miscellaneous compounds

\begin{tabular}{|c|c|c|c|c|c|}
\hline Reactant & $k\left(M^{-1} \mathrm{~s}^{-1}\right)$ & $\mathrm{pH}$ & Ref. & Method & Comments \\
\hline benzene sulfonate & $2.9 \times 10^{9}$ & & {$[56]$} & PR comp. with CNS ${ }^{-}$ & Rel. to $k_{\text {thiocyan. }}^{\text {rel. }}=1.1 \times 10^{10}$ \\
\hline ethane sulfonate & $1.0 \times 10^{7}$ & & {$[56]$} & PR comp. with $\mathrm{CNS}^{-}$ & Rel. to $k_{\text {thiocyan. }}^{\text {rel. }}=1.1 \times 10^{10}$ \\
\hline glutamine & $(1.4 \pm 0.15) \times 10^{8}$ & 2 & {$[19]$} & $S$ irrad. comp. with thymine & Rel. to $k_{\mathrm{OH}+\text { thymine }}=4.7 \times 10^{9}$ \\
\hline $\begin{array}{l}\text { poly(ethylene- } \\
\text { sulfonate) }\end{array}$ & $1.2 \times 10^{7}$ & & {$[56]$} & PR comp. with $\mathrm{CNS}^{-}$ & Rel. to $k_{\text {thiocyan. }}^{\text {rel. }}=1.1 \times 10^{10}$ \\
\hline $\begin{array}{l}\text { poly(styrene- } \\
\text { sulfonate) }\end{array}$ & $3.3 \times 10^{8}$ & & {$[56]$} & PR comp. with $\mathrm{CNS}^{-}$ & Rel. to $k_{\text {thiocyan. }}^{\text {rel. }}=1.1 \times 10^{10}$ \\
\hline toluene sulfonate & $3.0 \times 10^{9}$ & & {$[56]$} & PR comp. with $\mathrm{CNS}^{-}$ & Rel. to $k_{\text {thiocvan. }}^{\mathrm{rel} .}=1.1 \times 10^{10}$ \\
\hline $\begin{array}{l}\text { nor-pseudo-peller- } \\
\text { tierine-N-oxyl } \\
\text { (NPPN) }\end{array}$ & $(7.4 \pm 1) \times 10^{9}$ & alk. & {$[60]$} & PR comp. with $\mathrm{CO}_{\overline{3}}^{\overline{3}}$ & Rel. to $k_{\mathrm{OH}+\mathrm{CO}_{3}^{2-}}=4.1 \times 10^{8}$ \\
\hline sodium sulfacetamide & $8.1 \times 10^{9}$ & & {$[61]$} & S irrad. comp. with PNDA & $\begin{array}{l}\text { Rel. to } k_{(\mathrm{OH}+\mathrm{PNDA}}=1.25 \times 10^{10} \\
\quad(\text { Values interpolated from data) }\end{array}$ \\
\hline sulfanilic acid & $6.3 \times 10^{9}$ & & {$[61]$} & S irrad. comp. with PNDA & $\begin{array}{l}\text { Rel. to } k_{\mathrm{OH}+\mathrm{PNDA}}=1.25 \times 10^{10} \\
\text { (Values interpolated from data) }\end{array}$ \\
\hline sulfanilamide & $6.0 \times 10^{9}$ & & {$[61]$} & S irrad. comp. with PNDA & $\begin{array}{l}\text { Rel. to } k_{\mathrm{OH}+\mathrm{PNDA}}=1.25 \times 10^{10} \\
\quad \text { (Values interpolated from data) }\end{array}$ \\
\hline $\begin{array}{l}\text { triacetoneamine- } N \text { - } \\
\text { oxyl }\end{array}$ & $(4.3 \pm 0.5) \times 10^{9}$ & alk. & {$[60]$} & PR comp. with $\mathrm{CO}_{3}^{=}$ & Rel. to $k_{\mathrm{OH}+\mathrm{CO}_{\bar{i}}}=4.1 \times 10^{8}$ \\
\hline
\end{tabular}


TABLE 20. Miscellaneous compounds-Continued

\begin{tabular}{|c|c|c|c|c|c|}
\hline Reactant & $k\left(M^{-1} \mathrm{~s}^{-1}\right)$ & $\mathrm{pH}$ & Ref. & Method & Comments \\
\hline eosin & $2 \times 10^{10}$ & 8.5 & {$[62]$} & PR comp. with $\mathrm{CO}_{3}^{=}$ & 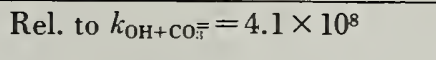 \\
\hline eosin-Y & $1.4 \times 10^{9}$ & 10.5 & {$[63]$} & PR comp. with $\mathrm{CO}_{3}^{=}$ & Rel. to $k_{\mathrm{OH}+\mathrm{CO}_{3}}=4.1 \times 10^{8}$ \\
\hline eosin dianion & $\begin{array}{l}* 1.7 \times 10^{9}(\mathrm{i}) \\
{ }^{*} 6 \times 10^{8}(\mathrm{ii})\end{array}$ & 9 & {$[64]$} & PR product form. & $\begin{array}{l}\text { Absolute. Computer analysis. } \\
\text { (i) electron transfer reaction } \\
\text { (ii) OH-addition }\end{array}$ \\
\hline fluoroscein & $\begin{array}{l}*(1.6 \pm 0.3) \times 10^{9}(\mathrm{i}) \\
*(1.4 \pm 0.2) \times 10^{9}(\mathrm{ii})\end{array}$ & 9.2 & {$[65]$} & PR product form. & $\begin{array}{l}\text { Absolute computer analysis. } \\
\text { (i) electron transfer reaction } \\
\text { (ii) } \mathrm{OH} \text {-addition }\end{array}$ \\
\hline indole & $(1.37 \pm 0.5) \times 10^{10}$ & 9 & {$[66]$} & S irrad. comp. with PNDA & $\begin{array}{l}\text { Rel. to tryptophan } \\
k_{\mathrm{OH}+\text { tryptophan }}=1.25 \times 10^{10}\end{array}$ \\
\hline indoline & $(2.02 \pm 0.14) \times 10^{10}$ & 9 & {$[66]$} & S irrad. comp. with PNDA & $\begin{array}{l}\text { Rel. to tryptophan } \\
\quad k_{\mathrm{OH}+\text { tryptophan }}=1.25 \times 10^{10}\end{array}$ \\
\hline l-methylindole & $(1.44 \pm 0.01) \times 10^{10}$ & 9 & {$[66]$} & S irrad. comp. with PNDA & $\begin{array}{l}\text { Rel. to tryptophan } \\
\qquad k_{\mathrm{OH}+\text { tryptophan }}=1.25 \times 10^{10}\end{array}$ \\
\hline 2-methylindole & $1.44 \times 10^{10}$ & 9 & {$[66]$} & S irrad. comp. with PNDA & $\begin{array}{l}\text { Rel. to tryptophan } \\
\qquad k_{\mathrm{OH}+\text { tryptophan }}=1.25 \times 10^{10}\end{array}$ \\
\hline 3-methylindole & $1.05 \times 10^{10}$ & 9 & {$[66]$} & S irrad. comp. with PNDA & $\begin{array}{l}\text { Rel. to tryptophan } \\
k_{\mathrm{OH}+\text { tryptophan }}=1.25 \times 10^{10}\end{array}$ \\
\hline 1,2-dimethylindole & $(1.25 \pm 0.02) \times 10^{10}$ & 9 & {$[66]$} & S irrad. comp. with PNDA & $\begin{array}{l}\text { Rel. to tryptophan } \\
k_{\text {OH+tryptophan }}=1.25 \times 10^{10}\end{array}$ \\
\hline 1,3-dimethylindole & $(1.01 \pm 0.08) \times 10^{10}$ & 9 & {$[66]$} & S irrad. comp. with PNDA & $\begin{array}{l}\text { Rel. to tryptophan } \\
k_{\mathrm{OH}+\text { tryptophan }}=1.25 \times 10^{10}\end{array}$ \\
\hline 2,3-dimethylindole & $(1.26 \pm 0.01) \times 10^{10}$ & 9 & {$[66]$} & S irrad. comp. with PNDA & $\begin{array}{l}\text { Rel. to tryptophan } \\
k_{\mathrm{OH}+\text { tryptophan }}=1.25 \times 10^{10}\end{array}$ \\
\hline 5-methylindole & $(1.66 \pm 0.06) \times 10^{10}$ & 9 & {$[66]$} & $S$ irrad. comp. with PNDA & $\begin{array}{l}\text { Rel. to tryptophan } \\
k_{0 H+\text { tryptophan }}=1.25 \times 10^{10}\end{array}$ \\
\hline 5-chloroindole & $(1.91 \pm 0.06) \times 10^{10}$ & 9 & {$[66]$} & $S$ irrad. comp. with PNDA & $\begin{array}{l}\text { Rel. to tryptophan } \\
k_{\mathrm{OH}+\text { tryptophan }}=1.25 \times 10^{10}\end{array}$ \\
\hline 5-bromoindole & $(1.57 \pm 0.18) \times 10^{10}$ & 9 & {$[66]$} & S irrad. comp. with PNDA & $\begin{array}{l}\text { Rel. to tryptophan } \\
k_{\mathrm{OH}+\text { tryptophan }}=1.25 \times 10^{10}\end{array}$ \\
\hline 5-hydroxyindole & $(1.67 \pm 0.10) \times 10^{10}$ & 9 & {$[66]$} & rrad. comp. with PNDA & $\begin{array}{l}\text { Rel. to tryptophan } \\
k_{\mathrm{OH}+\text { tryptophan }}=1.25 \times 10^{10}\end{array}$ \\
\hline 5-methoxyindole & $(1.39 \pm 0.04) \times 10^{10}$ & 9 & {$[66]$} & S irrad. comp. with PNDA & $\begin{array}{l}\text { Rel. to tryptophan } \\
\quad k_{\mathrm{OH}+\text { tryptophan }}=1.25 \times 10^{10}\end{array}$ \\
\hline 5-amido indole & $(3.17 \pm 0.31) \times 10^{10}$ & 9 & {$[66]$} & S irrad. comp. with PNDA & $\begin{array}{l}\text { Rel. to tryptophan } \\
k_{\mathrm{OH}+\text { tryptophan }}=1.25 \times 10^{10}\end{array}$ \\
\hline 5-nitroindole & $(1.25 \pm 0.24) \times 10^{10}$ & 9 & {$[66]$} & S irrad. comp. with PNDA & $\begin{array}{l}\text { Rel. to tryptophan } \\
\quad k_{\mathrm{OH}+\text { tryptophan }}=1.25 \times 10^{10}\end{array}$ \\
\hline 5-cyanoindole & $(1.06 \pm 0.24) \times 10^{10}$ & 9 & {$[66]$} & S irrad. comp. with PNDA & $\begin{array}{l}\text { Rel. to tryptophan } \\
k_{\mathrm{OH}+\text { tryptophan }}=1.25 \times 10^{10}\end{array}$ \\
\hline indole-5-acetic acid & $(0.79 \pm 0.07) \times 10^{10}$ & 9 & {$[66]$} & S irrad. comp. with PNDA & $\begin{array}{l}\text { Rel. to tryptophan } \\
k_{\mathrm{OH}+\text { tryptophan }}=1.25 \times 10^{10}\end{array}$ \\
\hline
\end{tabular}




\section{Chapter X. References}

[1] Garrison, W. M., Current Topics in Radiation Research, p. 45, Eds. M. Ebert and A. Howard (North Holland Publishing Co., Amsterdam, 1968).

[2] Holian, J., and Garrison, W. M., unpublished results. (May be obtained from L. M. Dorfman, Ohio State University, Columbus, Ohio 43210.)

[3] Land, E. J., and Ebert, M., Trans. Faraday Soc. 63, 1181 (1967).

[4] Jayson, G. G., Scholes, G., and Weiss, J., Biochem. J. 57, 386 (1954).

[5] Eich, E., and Rochelmeyer, H., Pharm. Acta. Helv. 41, 109 (1966).

[6] Armstrong, R. C., and Swallow, A. J., Radiation Res. 440, 563 (1969).

[7] Karmann, W., Meissner, G., and Henglein, A., Zeit. für Naturforsch. B22, 273 (1967).

[8] Adams, G. E., McNaughton, G. S., and Michael, B. D., The Chemistry of Ionisation and Excitation, p. 281, Eds. G. R. A. Johnson and G. Scholes, (Taylor and Francis Ltd., London, 1967).

[9] Swallow, A. J., J. Chem. Soc., 1334 (1952).

[10] Charlesby, A., Fydelor, P. J., Kopp, P. M., Keene, J. P., and Swallow, A. J., Pulse Radiolysis, p. 193, Ed. M. Ebert et al., (Academic Press, London and New York, 1965).

[11] Badiello, R., and Fielden, E. M., Int. J. Rad. Biol. 17, 1 (1970).

[12] Barron, E., Johnson, P., and Cobure, A., Radiation Res. 1, 410 (1954).

[13] Scholes, G., Ward, J. F., and Weiss, J. J., J. Mol. Biol. 2, 379 (1960).

[14] Scholes, G., Weiss, J. J., and Wheeler, C. M., Nature 178, 157 (1956).

[15] Daniels, M., Scholes, G., Weiss, J. J., and Wheeler, C. M., J. Chem. Soc., 226 (1957).

[16] B. Ekurt and R. Monier, Nature 184, BA58 (1959).

[17] Latarjet, R., Ekert, B., Apelgot, S., and Reybeyrotte, N., J. Chim. Phys. 58, 1046 (1961).

[18] Scholes, G., and Weiss, J. J., Nature 185, 305 (1960).

[19a] Ward, J. F., and Myers, L. S., Jr., Radiation Res. 26, 483 (1965).

[19b] Scholes, G., and Willson, R. L., Trans. Faraday Soc. 63, 2983 (1967).

[20] Myers, L. S., Jr., Ward, J. F., Tsukamoto, W. T., Holmes, D. E., and Julia, J. P., Science 148, 1234 (1965).

[21] Holian, J., and Garrison, W. M., Nature 212, 394 (1966).

[22] Scholes, G., and Weiss, J. J., Exp. Cell. Res. Suppl. 2, 219 (1952).

[23] Scholes, G., and Weiss, J. J., Biochem. J. 53, 567 (1963).

[24] Conlay, J. J., Nature 197,555 (1963).

[25] Holian, J., and Garrison, W. M., J. Phys. Chem. 71, 462 (1964).

[26] Holian, J., and Garrison, W. M., Chem. Comm. 14, 676 (1967).

[27] Emmerson, P. T., Scholes, G., Thompson, D., Ward, J. F., and Weiss, J. J., Nature 187, 319 (1960).

[28] Adams, G. E., Boag, J. W., Currant, J., and Michael, B. D., Pulse Radiolysis, p. 131, Ed. M. Ebert et al. (Acad. Press, London and New York, 1965).

[29] Scholes, G., Shaw, P., Willson, R. L., and Ebert, M., Pulse Radiolysis, p. 151, Ed. M. Ebert et al. (Acad. Press, London and New York, 1965)

[30] Meissner, G., Henglein, A., and Beck, G., Zeit. für Naturforsch. 22, 13 (1967).

[31] Schoeneshoefer, M., Karmann, W., and Henglein, A., Int. J. Rad. Phys. and Chem. 1, 407 (1969).

[32] Karmann, W., Granzow, A., Meissner, G., and Henglein, A., Int. J. Rad. Phys. and Chem. 1, 395 (1969).

[33] Jayson, G. G., Stirling, D. A., and Swallow, A. J., Int. J. Rad. Biol. 19, 143 (1971).
[34] Scholes, G., Willson, R. L., and Ebert, M., Chem. Comm., 17 (1969).

[35] Rabani, J., and Stein, G., Trans. Faraday Soc. 58, 2150 (1962).

[36] Anbar, M., Meyerstein, D., and Neta, P., J. Chem. Soc., 742 (1966).

[37] Matthews, R. W., and Sangster, D. F., J. Phys. Chem. 69, 1938 (1965).

[38] Willson, R. L., Greenstock, C. L., Adams, G. E., Wageman, R., and Dorfman, L. M., Int. J. Rad. Phys. and Chem. 3, 211 (1971).

[39] Chrysochoos, J., Radiation Res., 33, 465 (1968).

[40] Zimbrick, J. D., Ward, J. F., and Myers, L. S., Jr., Int. J. Rad. Biol. 16,505 (1969).

[41] Simic, M., Neta, P., and Hayon, E., J. Amer. Chem. Soc. 92 , 4763 (1970).

[42] Kraljic, I., Chemistry of Ionisation and Excitation, p. 303, Eds. G. R. A. Johnson and G. Scholes (Taylor and Francis Ltd., London, 1967).

[43] Davies, J. V., Ebert, M., and Quintilliani, M., in Radiation Protection and Sensitisation, p. 87, Eds. H. L. Moroson and M. Quintilliani (Taylor and Francis Ltd., London, 1970).

[44] Henglein, A., Karmann, W., Roebke, W., and Beck, G., Makromol. Chem. 92, 105 (1966).

[45] Adams, G. E., Aldrich, J. E., Cundall, R. B., and Willson, R. L., Int. J. Rad. Biol. 16, 333 (1969).

[46] Davies, J. V., Ebert, M., and Shalek, R. J., Int. J. Rad. Biol. 14, 19 (1968).

[47] Braams, R., and Ebert, M., Advances in Chemistry Series No. 81, Radiation Chemistry I, 464, Ed. R. F. Gould (1968).

[48] Masuda, T., Ovadia, J., and Grossweiner, L. I., Int. J. Rad. Biol. 20, 447 (1971).

[49] Greenstock, C. L., Ng, M., and Hunt, J. W., Advances in Chemistry Series No. 81, Radiation Chemistry, 397, Ed. R. F. Gould (1968).

[50] Ward, J. F., and Myers, L. S., Jr., Radiation Res. 26, 483 (1965).

[51] Myers, L. S., Jr., Hollis, M. L., and Theard L. M., Advances in Chemistry Series No. 81, Radiation Chemistry I, 345, Ed. R. F. Gould (1968).

[52] Loman, H., and Blok, J., Radiation Res. 36, 1 (1968).

[53] Greenstock, C. L., Hunt, J. W., and Ng, N., Trans. Faraday Soc. 65, 3279 (1969).

[54] Greenstock, C. L., Trans. Faraday Soc. 66, 2541 (1970).

[55] Moore, J. S., Phillips, G. O., Davies, J. V., and Dodgson, K. S., Carbohyd. Res. 12, 253 (1970).

[56] Balazs, E. A., Davies, J. V., Phillips, G. O., and Scheufele, D. S., J. Chem. Soc., 1420 (1968).

[57] Davies, J. V., Griffiths, W., and Phillips, G. O., Pulse Radiolysis, p. 181, Ed. M. Ebert et al. (Academic Press, London and New York, 1965).

[58] Balazs, E. A., Davies, J. V., Phillips, G. O., and Young, M. D., Radiation Res. 31, 243 (1967).

[59] Jooyandeh, F., Moore, J. S., Morgan, R. E., and Phillips, G. O., Radiation Research 45, 455 (1971).

[60] Fielden, E. M., and Roberts, P. B., Int. J. Rad. Biol. 20 , 355 (1971).

[61] Phillips, G. O., Power, D. M., and Sewart, M., Radiation Res. 46, 236 (1971).

[62] Grossweiner, L. I., Redde, A. F., Jr., Sandberg, G., and Chrysochoos, J., Nature 210,1154 (1966).

[63] Chrysochoos, J., Ovadia, J., and Grossweiner, L. I., J. Phys. Chem. 71, 1629 (1967).

[64] Grossweiner, L. I., Advances in Chemistry Series, No. 81, Radiation Chemistry I, 309, Ed. R. F. Gould (1968).

[65] Cordier, P., and Grossweiner, L. I., J. Phys. Chem. 72, 2018 (1968).

[66] Iddon, B., Phillips, G. O., Robbins, K. E., and Davies, J. V., J. Chem. Soc. (B), 1887 (1971).

[67] Zimbrick, J. D., Ward, J. F., and Myers, L. S., Jr., Int. J. Rad. Biol. 16, 505 (1969). 


\section{Chapter XI. Cross-Correlation of Rate Constants}

It will be seen from the considerable number of $\mathrm{OH}$ rate constants listed in the tables that the large majority of those determined indirectly were obtained using one of three independent competition methods. The respective reference solutes in question are thiocyanate ion, thymine, and paranitrosodimethyl aniline (PNDA) [1-3]. While the thiocyanate system is restricted to the pulse radiolysis method, the other two solutes have been used to determine $\mathrm{OH}$ rate data by both stationarystate and pulse-radiolysis methods. The thiocyanate method utilizes the intense transient spectrum of the thiocyanate radical-ion (CNS) ${ }_{2}^{-}$as the reference absorption. This radical is formed in the electron transfer reaction:

$$
\begin{aligned}
& \mathrm{CNS}^{-}+\mathrm{OH}=\mathrm{CNS} \cdot+\mathrm{OH}^{-} \\
& \mathrm{CNS}++\mathrm{CNS}^{-} \leftrightharpoons(\mathrm{CNS})_{2}^{-}
\end{aligned}
$$

The experimental rate constant for its formation is $6.6 \times 10^{9} \mathrm{M}^{-1} \mathrm{~s}^{-1}$, which does not, in fact, correspond to $k_{1}$. This value had been adopted in numerous publications for calculation of rate data for a wide variety of inorganic, organic, and biological molecules. Because of its extensive usage the matter of the validity of the method merits careful scrutiny. It has been shown [4-6] that reaction (1) is not the rate-determining process for formation of $(\mathrm{CNS})_{2}^{-}$and, therefore, absolute rate constants calculated on the basis of $k_{1}=6.6$ $\times 10^{9} M^{-1} \mathrm{~s}^{-1}$ are all too low.

One detailed kinetic study of this system [4] has indicated an approximate value for $k_{1}$ of $2.8 \times 10^{10} M^{-1} \mathrm{~s}^{-1}$. Inspection shows that when several independent estimates of the $\mathrm{OH}$ reactivity of a given solute are available, the value determined by the thiocyanate method and calculated relative to this value for $k_{1}$ is, in all cases, too large by a factor of about three.

The data for ethanol serve to illustrate this point. Excluding values obtained by the thiocyanate method, there are 14 independent estimates of this rate constant listed in table 3 , all of which, with two exceptions, fall within the narrow range $1.6-1.9 \times 10^{9} \mathrm{M}^{-1} \mathrm{~s}^{-1}$. When the rate constant obtained by use of the thiocyanate system is calculated on the basis of $k_{1}=2.8 \times 10^{10} M^{-1} \mathrm{~s}^{-1}$, the value obtained, $4.6 \times 10^{9} \mathrm{M}^{-1} \mathrm{~s}^{-1}$, is clearly anomalous. In order to examine whether, in cases where replicate measurements by other methods are available, the thiocyanate data can be successfully normalized, we selected ethanol as a secondary standard, adopting, from competition data, the absolute value $1.85 \times 10^{9} \mathrm{M}^{-1} \mathrm{~s}^{-1}$ for the rate constant. All rate constants listed in this compilation which have been determined by the thiocyanate method, have been expressed relative to the above values for ethanol. From this value it follows that the corresponding calculated value for the rate constant of reaction (1) is $1.1 \times 10^{10} \mathrm{M}^{-1} \mathrm{~s}^{-1}$.

Toward the completion of this compilation a new determination [5] of $k_{1}$ gave the value $k_{1}=(1.08$ $\pm 0.10) \times 10^{10} \mathrm{M}^{-1} \mathrm{~s}^{-1}$, in excellent agreement with the value based on ethanol as a secondary standard. When the value $1.1 \times 10^{10}$ is used for calculating other rate constants determined using the thiocyanate method, agreement is generally good when the existence of independent estimates of these rate constants permits comparison. However, in spite of this apparent agreement, the discrepancy in the experimental determinations of the reference rate constant $k_{1}$ may raise questions as to the validity of the thiocyanate method particularly since the reference radical, $(\mathrm{CNS})_{2}^{-}$, is not formed in a onestage process.

There are over 140 solutes listed in this compilation for which rate constants have been determined by this technique. In order to investigate whether this large volume of data is at all reliable, we have examined methods of normalizing the values in terms of other standards. There are several solutes which can be used with confidence for this purpose. Multiple independent determinations are available for several of the alcohols. In most cases, the agreement is very good, e.g., methanol and ethanol. The scatter in the ethanol rate constant is small and there are eight independent estimations for which the scatter is within about \pm 10 percent of the mean value of $1.85 \times 10^{9} \mathrm{M}^{-1} \mathrm{~s}^{-1}$. Similar agreement is apparent for methanol. All rate constants listed in this compilation which have been determined by the thiocyanate method have been expressed relative to the above mean value for ethanol. Although the calculated value of $1.1 \times 10^{10}$ is in excellent agreement with the more recent determination of $k_{1}=$ $1.08 \times 10^{10}$, all data obtained by the thiocyanate method carry the qualification in the comment column $k_{\text {thiocyanate }}^{\text {rel. }}=1.1 \times 10^{10} M^{-1} \mathrm{~s}^{-1}$.

Inspection of the separate tables shows that normalization based on this value is successful in almost all cases where independent determinations permit a direct comparison. For comparison, a selection of these data, along with others, is listed in table 21. For such a large number of solutes, it seems most unlikely that the satisfactory agreement with independent data could arise by a chance cancellation of errors. Despite the existing disagree- 
$\left(\mathrm{M}^{-1} \mathrm{~s}^{-1} \times 10^{-9}\right)$

\begin{tabular}{|c|c|c|c|c|c|c|}
\hline Solute & $\begin{array}{c}\text { Absolute } \\
\text { measurement }\end{array}$ & $\begin{array}{l}\text { Ferro- } \\
\text { cyanide }\end{array}$ & $\begin{array}{l}\text { Thio- } \\
\text { cyanate }\end{array}$ & Thymine & PNDA & Benzoate \\
\hline methanol.... & 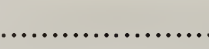 & 0.86 & 0.77 & 0.76 & 1.0 & 0.80 \\
\hline ethanol................ & .......... & 1.85 & 1.72 & 1.7 & 1.82 & 1.73 \\
\hline$n$-propanol... & & 2.7 & 2.5 & 2.7 & & \\
\hline 2-propanol... & & 2.0 & 1.8 & 1.9 & 2.1 & \\
\hline$n$-butanol..... & & 4.0 & 3.7 & 4.0 & & \\
\hline$t$-butanol.......... & & 5.2 & 4.2 & 6.3 & & \\
\hline ethylene glycol... & ........ & 1.47 & 1.44 & 1.5 & ... & \\
\hline glycerol................ & & 1.9 & 1.59 & 1.64 & & \\
\hline acrylamide....................... & 6.8 & 4.7 & 3.3 & & & \\
\hline benzoate................... & 5.9 & 5.4 & 5.5 & & 5.0 & \\
\hline acetophenone.............. & 6.0 & 5.2 & & & 4.8 & \\
\hline phenylalanine.. & 6.6 & 6.0 & 5.8 & 7.0 & & \\
\hline thymine........... & 4.7 & 4.7 & 5.2 & & & \\
\hline uracil.............. & 6.6 & & 6.0 & & 6.8 & \\
\hline acetone........ & ....... & 0.12 & 0.097 & 0.066 & 0.08 & 0.09 \\
\hline ferrocyanide. & 9.3 & & & & & \\
\hline PNDA.......... & 12.5 & & & & & \\
\hline thiocyanate. & & & b 11.0 & 9.2 & & \\
\hline
\end{tabular}

${ }^{a}$ Values shown in this table are, in many cases, an average of several determinations. Thus, the value for the absolute determination for benzoate, 5.9 , is the average of the two values 5.7 and 6.0 from table 2.

${ }^{\mathrm{b}}$ This value of 11.0 for thiocyanate is the value obtained in competition studies with ethanol, taking $k_{\mathrm{OH}+\mathrm{C}_{2} \mathrm{H}_{5} \mathrm{OH}}=1.85 \times 10^{9}$, and has been used as the reference value in the competition studies with CNS-

ment in the absolute value of the rate constant for reaction (1), it seems clear that the large amount of published data for $\mathrm{OH}$ reactivity obtained by the thiocyanate method need not be discarded.

The thymine and PNDA methods used most frequently for stationary-state determination of $\mathrm{OH}$ rate constants, are based upon radiation-induced bleaching of the respective solutes:

$$
\text { solute }+\mathrm{OH} \rightarrow \text { loss of chromophore. }
$$

In the presence of a second solute, the competition is measured by the decrease in the amount of $\mathrm{OH}$ induced loss of the reference chromophore absorption. Both methods have limitations, as is stressed by the respective authors of the original papers on the subject. The methods can be used for the determination of the reactivity of a given solute only under conditions where other reactions which can produce absorption at the reference wavelength are either absent or can be quantitatively assessed. Despite this limitation and, also, certain $\mathrm{pH}$ restrictions, data obtained by both these methods show generally good agreement with data obtained by other methods.

The chromophore in thymine is the 5-6 double bond which exhibits an absorption maximum at $260 \mathrm{~nm}$. Reaction of $\mathrm{OH}$ occurs by addition to the double bond resulting in a loss of this absorption. The subsequent fate of this $\mathrm{OH}$-adduct depends upon the nature of the competing solute. However, in all cases studied, the overall result of a stationary-state irradiation is a decrease in absorption at $260 \mathrm{~nm}$.

In principle, the absolute rate constant for the thymine reaction, (3), can be determined either by direct observation of the indirect bleaching due to $\mathrm{OH}$ addition, or by measurement of the rate of formation of the transient product which has an absorption at longer wavelengths. In neutral solution, values determined by these methods (table 18) range from $4.6-7.4 \times 10^{9} M^{-1} \mathrm{~s}^{-1}$. The rate constants determined by the reference to the ethanol standard and by competition with ferrocyanide ion all fall within a narrower range and we have adopted as the best value for this rate constant, the value $4.7 \times 10^{9} M^{-1} \mathrm{~s}^{-1}$.

Due to mechanistic requirements, rate constants determined by the PNDA method have been measured, in most instances, at $\mathrm{pH}$ 9. There are two independent estimates of the absolute value of the reference rate constants, namely, $1.25 \times 10^{10}$ $M^{-1} \mathrm{~s}^{-1}[7]$ and $1.8 \times 10^{10} M^{-1} \mathrm{~s}^{-1}$ [8]. Unfortunately, they do not agree. However, since calculation of the rate constant on the basis of the ethanol standard agrees precisely with the lower absolute measurement, we have adopted this value for calculation of the rate data, from competition studies, listed in the various tables. It is clear that, in general, the consistency is good when independent measurements permit direct comparison.

Although the ferrocyanide method (pulse radiolysis) has been used to determine relatively few rate 
constants, it is evident from table 21 that agreement with values determined by absolute methods is generally very good. There is little doubt attached to the authenticity of the absolute value of the reference rate constant and, in addition, the reference reaction is a one-electron transfer reaction in which both the reactant (ferrocyanide ion) and the product (ferricyanide ion) are stable chemical species. We consider, therefore, that the evidence to date justifies the acceptance of this method as a reliable competition method for the determination of $\mathrm{OH}$ rate constants.

\section{Chapter XI. References}

[1] Adams, G. E., Boag, J. W., Currant, J., and Michael, B. D., Pulse Radiolysis, p. 131, Ed. M. Ebert et al. (Acad. Press, London and New York, 1965).

[2] Scholes, G., Shaw, P., Willson, R. L., and Ebert, M., Pulse Radiolysis, p. 151, Ed. M. Ebert et al. (Acad. Press, London and New York, 1965).

[3] Kraljic, I., ${ }^{-}$and Trumbore, C. N., J. Amer. Chem. Soc. 87, 2547 (1965).

[4] Baxendale, J. H., Bevan, P. L. T., and Stott, D. A., Trans. Faraday Soc. 64, 2389 (1968).
[5] Ellison, D. H., Salmon, G. A., and Wilkinson, F., Proc. Roy. Soc. A328, 23 (1972).

[6] Behar, D., Bevan, P. L. T., and Scholes, G., J. Phys. Chem. $76,1537(1972)$

[7] Baxendale, J. H., and Khan, A. A., Int. J. Rad. Phys. and Chem. 1.11.(1969).

[8] Dainton, F. S., and Wiseall, B., Trans. Faraday Soc., 64, 694 (1968)

Most of the writing and compilation of tables in this monograph was done while one of us (LMD) was a Fellow of the John Simon Guggenheim Foundation, at the Royal Institution of Great Britain, in London. I am grateful to the Guggenheim Foundation and to my host at the Royal Institution, Professor Sir George Porter.

We are indebted to Dr. Alberta B. Ross of the Radiation Chemistry Data Center, University of Notre Dame, for providing us with many helpful lists of references. We acknowledge, with thanks, the help of Mrs. Mary Cook and Mrs. D. Woodman in typing the manuscript with its extensive tables. 



\section{Publications in the National Standard Reference Data Series National Bureau of Standards}

You may use this listing as your order form by checking the proper box of the publication(s) you desire or by providing the full identification of the publication you wish to purchase. The full letter symbols with each publication number and full title of the publication and author must be given in your order, e.g. NSRDS - NBS-21, Kinetic Data on Gas Phase Unimolecular Reactions, by S. W. Benson and H. E. O'Neal.

Pay for publications by check, money order, or Superintendent of Documents coupons or deposit account. Make checks and money orders payable to Superintendent of Documents. Foreign remittances should be

NSRDS-NBS I, National Standard Reference Data System-Plan of Operation, by E. L. Brady and M. B. Wallenstein, 1964 (15 cents), SD Catalog No. C13.48:1.

NSRDS-NBS 2, Thermal Properties of Aqueous Uni-univalent Electrolytes, by V. B. Parker, 1965 (45 cents), SD Catalog No. C13.48:2. NSRDS-NBS 3, Sec. 1, Selected Tables of Atomic Spectra, Atomic Energy Levels and Multiplet Tables, Si II, Si III, Si IV, by C. E. Moore, 1965 (35 cents), SD Catalog No. C13.48:3/Sec.1.

NSRDS-NBS 3, Sec. 2, Selected Tables of Atomic Spectra, Atomic Energy Levels and Multiplet Tables, Si I, by C. E. Moore, 1967 (20 cents), SD Catalog No. C13.48:3/Sec.2.

$\square$ NSRDS-NBS 3, Sec. 3, Selected Tables of Atomic Spectra, Atomic Energy Levels and Multiplet 'Tables, C I, C II, C III, C IV, C v, C vi, by C. E. Moore, 1970 (\$1), SD Catalog No. C13.48:3/Sec.3.

NSRDS-NBS 3, Sec. 4, Selected Tables of Atomic Spectra, Atomic Energy Levels and Multiplet Tables, $\mathbf{N}$ IV, $\mathbf{N}$ v, $\mathbf{N}$ vi, $\mathbf{N}$ vII, by made either by international money order or draft on an American bank. Postage stamps are not acceptable.

No charge is made for postage to destinations in the United States and possessions, Canada, Mexico, and certain Central and South American countries. To other countries, payments for documents must cover postage. Therefore, one-fourth of the price of the publication should be added for postage.

Send your order together with remittance to Superintendent of Documents, Government Printing Office, Washington, D.C. 20402.

C. E. Moore, 1971 (55 cents), SD Catalog No. C13.48:3/Sec.4.

NSRDS-NBS 3, Sec. 6, Selected Tables of Atomic Spectra, Atomic Energy Levels and Multiplet Tables, HI , D, T, by C. E. Moore, 1971 (In press), SD Catalog No. C13.48:3/Sec. 6. NSRDS-NBS 4, Atomic Transition Probabilities, Vol. I, Hydrogen Through Neon, by W. L. Wiese, M. W. Smith, and B. M. Glennon, 1966 (\$2.50), SD Catalog No. C13.48:4/Vol. I.

NSRDS-NBS 5, The Band Spectrum of Carbon Monoxide, by P. H. Krupenie, 1966 (70 cents), SD Catalog No. C13.48:5.

NSRDS-NBS 6, Tables of Molecular Vibrational Frequencies, Part 1 , by $T$. Shimanouchi, 1967 (40 cents), SD Catalog No. C13.48:6/Pt.1. Superseded by NSRDS-NBS 39 . NSRDS-NBS 7, High Temperature Properties and Decomposition of Inorganic Salts, Part 1. Sulfates, by K. H. Stern and E. L. Weise, 1966 (35 cents), SD Catalog No. C13.48:7/Pt.1.

NSRDS-NBS 8, Thermal Conductivity of Selected Materials, by R. W. Powell, C. Y. Ho, 
and P. E. Liley, 1966 (\$3). PB189698*

NSRDS-NBS 9, Tables of Bimolecular Gas Reactions, by A. F. Trotman-Dickenson and G. S. Milne. 1967 (\$2), SD Catalog No. C13.48:9. NSRDS-NBS 10, Selected Values of Electric Dipole Moments for Molecules in the Gas Phase, by R. D. Nelson, Jr., D. R. Lide, Jr., and A. A. Maryott, 1967 (40 cents), SD Catalog No. C13.48:10.

$\square$ NSRDS-NBS 11, Tables of Molecular Vibrational Frequencies, Part 2 , by $T$. Shimanouchi, 1967 (30 cents), SD Catalog No. C13.48:11/Pt.2. Superseded by NSRDS-NBS 39 . NSRDS-NBS 12, Tables for the Rigid Asymmetric Rotor: Transformation Coefficients from Symmetric to Asymmetric Bases and Expectation Values of $\mathbf{P}_{z}^{2}, \mathbf{P}_{z}^{4}$, and $\mathbf{P}_{z}^{6}$, by R. H. Schwendeman, 1968 (60 cents), SD Cata$\log$ No. C13.48:12.

NSRDS-NBS 13, Hydrogenation of Ethylene on Metallic Catalysts, by J. Horiuti and K. Miyahara, 1968 (\$1), SD Catalog No. C13.48:13.

NSRDS-NBS 14, X-Ray Wavelengths and XRay Atomic Energy Levels, by J. A. Bearden, 1967 (40 cents), SD Catalog No. C13.48:14.

NSRDS-NBS 15, Molten Salts: Vol. 1, Electrical Conductance, Density, and Viscosity Data, by G. J. Janz, F. W. Dampier, G. R. Lakshminarayanan, P. K. Lorenz, and R. P. T. Tomkins, 1968 (\$3), SD Catalog No. C13.48:15/Vol.l.

NSRDS-NBS 16, Thermal Conductivity of Selected Materials, Part 2, by C. Y. Ho, R. W. Powell, and P. E. Liley, 1968 (\$2), SD Catalog No. C13.48:16/Pt.2.

NSRDS-NBS 17, Tables of Molecular Vibrational Frequencies, Part 3 , by $\mathrm{T}$. Shimanouchi, 1968 (30 cents), SD Catalog No. C13.48:17/Pt.3. Superseded by NSRDS-NBS 39. NSRDS-NBS 18, Critical Analysis of the HeatCapacity Data of the Literature and Evaluation of Thermodynamic Properties of Copper, Silver, and Gold from 0 to $300 \mathrm{~K}$, by G. T. Furukawa, W. G. Saba, and M. L. Reilly, 1968 (40 cents), SD Catalog No. C13.48:18.

NSRDS-NBS 19, Thermodynamic Properties of Ammonia as an Ideal Gas, by L. Haar, 1968 (20 cents), SD Catalog No. C13.48:19.

$\square$ NSRDS-NBS 20, Gas Phase Reaction Kinetics of Neutral Oxygen Species, by H. S.

*Available from National Technical Information Scrvice, Spring. field. Virginia 22151.
Johnston, 1968 (45 cents), SD Catalog No. C13.48:20.

NSRDS-NBS 21, Kinetic Data on Gas Phase Unimolecular Reactions, by S. W. Benson and H. E. O’Neal, 1970 (\$7), SD Catalog No. C13.48:21.

NSRDS-NBS 22, Atomic Transition Probabilities, Vol. II, Sodium Through Calcium, A Critical Data Compilation, by W. L. Wiese, M. W. Smith, and B. M. Miles, 1969 (\$4.50), SD Catalog No. C13.48:22/Vol.II.

NSRDS-NBS 23, Partial Grotrian Diagrams of Astrophysical Interest, by C. E. Moore and P. W. Merrill, 1968 (55 cents), SD Catalog No. C13.48:23.

NSRDS-NBS 24, Theoretical Mean Activity Coefficients of Strong Electrolytes in Aqueous Solutions from 0 to $100{ }^{\circ} \mathrm{C}$, by Walter J. Hamer, 1968 (\$4.25), SD Catalog No. C13.48:24. NSRDS-NBS 25, Electron Impact Excitation of Atoms, by B. L. Moiseiwitsch and S. J. Smith, 1968 (\$2), SD Catalog No. C13.48:25.

NSRDS-NBS 26, Ionization Potentials, Appearance Potentials, and Heats of Formation of Gaseous Positive Ions, by J. L. Franklin, J. G. Dillard, H. M. Rosenstock, J. T. Herron, K. Draxl, and F. H. Field, 1969 (\$4), SD Catalog No. C13.48:26.

NSRDS-NBS 27, Thermodynamic Properties of Argon from the Triple Point to $300 \mathrm{~K}$ at Pressures to 1000 Atmospheres, by A. L. Gosman, R. D. McCarty, and J. G. Hust, 1969 (\$1.25), SD Catalog No. C13.48:27.

NSRDS-NBS 28, Molten Salts: Vol. 2, Section 1. Electrochemistry of Molten Salts: Gibbs Free Energies and Excess Free Energies from Equilibrium-Type Cells, by G. J. Janz and C. G. M. Dijkhuis; Section 2. Surface Tension Data, by G. J. Janz, G. R. Lakshminarayanan, R. P. T. Tomkins, and J. Wong, 1969 (\$2.75), SD Catalog No. C13.48:28/Vol.2.

NSRDS-NBS 29, Photon Cross Sections, Attenuation Coefficients, and Energy Absorption Coefficients from $10 \mathrm{keV}$ to $100 \mathrm{GeV}$, by J. H. Hubbell, 1969 (75 cents), SD Catalog No. C13.48:29.

NSRDS-NBS 30, High Temperature Properties and Decomposition of Inorganic Salts, Part 2. Carbonates, by K. H. Stern and E. L. Weise, 1969 (45 cents), SD Catalog No. C13.48:30/Pt.2.

NSRDS-NBS 31, Bond Dissociation Energies 
in Simple Molecules, by B. deB. Darwent, 1970 (55 cents), SD Catalog No. C13.48:31.

NSRDS-NBS 32, Phase Behavior in Binary and Multicomponent Systems at Elevated Pressures: $n$-Pentane and Methane- $n$-Pentane, by V. M. Berry and B. H. Sage, 1970 (70 cents), SD Catalog No. C13.48:32.

NSRDS-NBS 33, Electrolytic Conductance and the Conductances of the Halogen Acids in Water, by W. J. Hamer and H. J. DeWane, 1970 (50 cents), SD Catalog No. C13.48:33.

NSRDS-NBS 34, Ionization Potentials and Ionization Limits Derived from the Analyses of Optical Spectra, by C. E. Moore, 1970 (75 cents), SD Catalog No. C13.48:34.

$\square$ NSRDS-NBS 35, Atomic Energy Levels as Derived from the Analyses of Optical Spectra, Vol. I, ${ }^{1} \mathrm{H}$ to ${ }^{23} \mathrm{~V}$; Vol. II, ${ }^{24} \mathrm{Cr}$ to ${ }^{41} \mathrm{Nb}$; Vol. III, ${ }^{\text {t2 }} \mathrm{Mo}$ to ${ }^{57} \mathrm{La},{ }^{72} \mathrm{Hf}$ to ${ }^{89} \mathrm{Ac}$, by C. E. Moore, 1971 (Vol. I, \$5; Vol. II, \$4.25; Vol. III, $\$ 4.50)$, SD Catalog No. C13.48:35/Vols. I, II, and III.

NSRDS-NBS 36, Critical Micelle Concentrations of Aqueous Surfactant Systems, by P. Mukerjee and K. J. Mysels, 1971 (\$3.75), SD Catalog No. C13.48:36.

NSRDS-NBS 37 , JANAF Thermochemical Tables, 2d Edition, by D. R. Stull, H. Prophet, et al., 1971 (\$9.75), SD Catalog No. C13.48:37.
NSRDS-NBS 38, Critical Review of Ultraviolet Photoabsorption Cross Sections for Molecules of Astrophysical and Aeronomic Interest, by R. D. Hudson, 1971 (\$1), SD Catalog No. C13.48:38.

NSRDS-NBS 39, Tables of Molecular Vibrational Frequencies, Consolidated Tables, by T. Shimanouchi, 1972 (In press), SD Catalog No. C13.48:39.

NSRDS-NBS 40, A Multiplet Table of Astrophysical Interest (Reprint of 1945 Edition), by C. E. Moore, 1972 (\$2), SD Catalog No. C13.48:40. NSRDS-NBS 41, Crystal Structure Transformations in Binary Halides, by C. N. R. Rao, 1972 (In press), SD Catalog No. C13.48:41.

NSRDS-NBS 42, Selected Specific Rates of Reactions of the Solvated Electron in Alcohols, by E. Watson, Jr., and S. Roy, 1972 (In press), SD Catalog No. C13.48:42.

NSRDS-NBS 43, Selected Specific Rates of Reactions of Transients from Water in Aqueous Solution, by M. Anbar, M. Bambenek, and A. B. Ross, 1972 (In press), SD Catalog No. C13.48:43.

NSRDS-NBS 44, The Radiation Chemistry of Gaseous Ammonia, by D. B. Peterson, 1972 (In press), SD Catalog No. C13.48:44. 

FORM NBS-114A $(1.71)$

\begin{tabular}{|c|c|c|c|}
\hline $\begin{array}{l}\text { U.S. DEPT. OF COMM. } \\
\text { BIBLIOGRAPHIC DATA } \\
\text { SHEET }\end{array}$ & $\begin{array}{l}\text { 1. PUBLICATION OR REPORT NO. } \\
\text { NSRDS - IBS }-46\end{array}$ & $\begin{array}{l}\text { 2. Gov't Accession } \\
\text { No. }\end{array}$ & 3. Recipient's Accession No. \\
\hline \multicolumn{3}{|l|}{ 4. TIT LE AND SUBTITLE } & 5. Publication Date \\
\hline \multirow{2}{*}{\multicolumn{3}{|c|}{ Reactivity of the Hydroxyl Radical in Aqueous Solutions }} & June 1973 \\
\hline & & & 6. Performing Organization Code \\
\hline \multicolumn{3}{|c|}{ Leon M. Dorfman and Gerald E. Adams } & 8. Performing Organization \\
\hline \multicolumn{3}{|c|}{ 9. PERF ORMING ORGANIZATION NAME AND ADDRESS } & 10. Project/Task/Work Unit No. \\
\hline \multicolumn{3}{|c|}{$\begin{array}{l}\text { NAT IONAL BUREAU OF STAND ARDS } \\
\text { DEP ARTMENT OF COMMERCE } \\
\text { WASHINGTON, D.C. } 20234\end{array}$} & 11. Contract/Grant No. \\
\hline \multicolumn{3}{|c|}{ 12. Sponsoring Organization Name and Address } & $\begin{array}{l}\text { 13. Type of Report \& Period } \\
\text { Covered }\end{array}$ \\
\hline \multicolumn{3}{|c|}{ Same as No. 9.} & Final \\
\hline & & & 14. Sponsoring Agency Code \\
\hline
\end{tabular}

15. SUPPLEMENTARY NOTES

16. ABSTRACT (A 200-word or less factual summary of most significant information. If document includes a significant bibliography or literature survey, mention it here.)

The reaction rate data of the hydroxyl radical in aqueous solution are compiled and evaluated in this critical review. The values are reported in a series of tables covering additon, hydrogen abstraction, inorganic electron transfer and radical reactions. Rate constants for the hydroxyl radical with biological molecules are included. In addition, the rate constant data for the oxide radical ion are given. Physical properties are listed and the experimental methods employed in OH radical chemistry are reviewed. An analysis involving rate constant data comparisons is made.

17. KEY WORDS (Alphabetical order, separated by semicolons)

Abstraction reactions; addition reactions; aqueous solution; biological molecules; electron transfer reactions; hydroxyl radical; oxide radical ion; radical reactions; rate constants; reference data.

18. AVAILABILITY STATEMENT

UNL IMIT ED.

FOR OFFICIAL DISTRIBUTION. DO NOT RELEASE TO NTIS.

\begin{tabular}{|l|c|}
$\begin{array}{l}\text { 19. SECURITY CLASS } \\
\text { (THIS REPORT) }\end{array}$ & $\begin{array}{c}\text { 21. NO. OF PAGES } \\
\text { UNCL ASSIF IED }\end{array}$ \\
\hline $\begin{array}{l}\text { 20. SECURITY CLASS } \\
\text { (THIS PAGE) }\end{array}$ & $\begin{array}{c}\text { 22. Price } \\
90 \text { cents } \\
\text { domestic }\end{array}$ \\
\hline
\end{tabular}




\section{Announcement of New Publications in}

National Standard Reference Data Series

Superintendent of Documents,

Government Printing Office,

Washington, D.C. 20402

Dear Sir:

Please add my name to the announcement list of new publications to be issued in the series: National Standard Reference Data Series - National Bureau of Standards.

Name

Company

Address

City___ State__ Zip Code_

(Notification key $\mathrm{N}-337$ )

U. S. GOVERNMENT PRINTING OFFICE : 1973 OL - 492-021 


\section{NBS TECHNICAL PUBLICATIONS}

\section{PERIODICALS}

IOL'RNAL OF RESEARCH reports National him sis of Standards research and derclopment in thesers rathematics. and chem'str: Comprotensive venifio papers give onmpletr details of the work. uelading laboraton data. experimental procedures. wheomtical and math matical analises. Illistrated at) pholographs. drawings, and charts. Includes wags of other NBS papers as issued.

sanbins in tuo sectuon, arailable separately:

\section{Physics and Chemistry (Section A)}

Foors of interest primarils to scientiste working in fields. This sertion covers a hroad range of hyoral and ch mical revarch, with maior emphasis in tandards of phreical measurement. fiındamental sustants, and propirties of matter Issued six times war. Annual i heription: Domestic, \$17 010 : For*n. $\$ 21.25$

\section{* Mathematical Sciences (Section B)}

Ludies and compilations decigned manly for the whematician and thennetical phrsicist. Topics in wathematical statistics. thenly of experiment design. immerical analvsis. thenetical phrsics and chemistry; weral decinen and programming of compiters and wivowiter stems, Short nu merical tables Iscued quarof Anniral subscription. Domestic. $\$ 9.00$ : Foreign 1) 27

\section{TECHNICAL NEWS BULLETIN}

The best single source of information concerning the fuleav's measirement, research, developmental. coneratre, and publication activities this monthls asblication is decigned for the industrs-oriented wividual wh/s daly work inrolves intimate contact

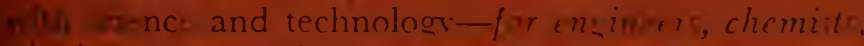
ohpuitirts, reviatch manaver. producl-deielopment Moway $r$, and campans recculie s. Inclides listing of sil NBS papers as issued. Annual s.bscription: Domair. \$6.50, Fortign. $\$ 825$.

\section{KONPERIODICALS}

Applied Mathematics Series. Mathematical tables. 11 anmals, and studies.

Building Science Series. Research results, test mithod and performance criteria of building matrials. components. sistems, and structures.

Handbooks. Recomm nded codes of engineering and indistral practice including safety codes) dereloped in cooperation with interested industries. profecsional organizations, and regulatory bodies.

Special Publications. Proceedings of NBS conferences. bib ingraphies, annual reports, wall charts, pamphlets, etc.

Monographs. Major contributions to the technical literature on various subjects related to the Bureau's scirntific and technical activities.

National Standard Reference Data Series. NSRDS provides quantitative data on the physical and chemical properties of materials, compiled from the world's literature and critically evaluated.

Product Standards. Provide requirements for sizes, twpes qualitv, and methods for tecting various industrial products. These standards are developed conperativelv with interested Government and industry groups and provide the basis for common understanding of product characteristics for both buvers and sclers. Their use is voluntar:

Technical Notes. This series consists of communications and repors cosering hoth nther-agencr and VBS-sponsored work of limited or transitor interest.

Federal Information Processing Standards Publications. This series is the official publication within the Federal Government for information on standards adopted and promulgated under the Public Law 89-306. and Bireais of the Budget Circular A-86 entitled. Standardization of Data Elements and Codes in Data Srctems.

Consumer Information Series. Practical informatinn. havd on NBS research and experience, covering areas of interest to the consumer. Easily understandable language and illustrations provide useful backrround knowledge for shopping in today's technological marketplace.

\section{BIBLIOGRAPHIC SLBSCRIPTIOY SERVICES}

The following current-awareness and literature-survey bibliographies are issued periodically by the Bureau :

Cryogenic Data Center Current A wareness Service Publications and Reports of Interest in Crogenics

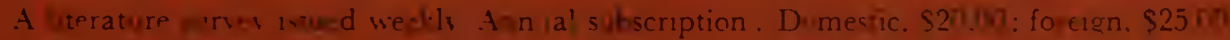

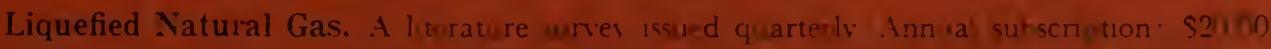

Superconducting Devices and Materials. A literature surm i sued quarterls. Annwal a bacription. \$2000 Sind soise ription oders and remittances for the preceding bibliogaphic services to the L S Department of Commercr. National Tref nical Infrmat on Service Sprinufield Va 22151

Electromagnetic Metrology Current Awareness Service (An-tratts of Ceircted Arvich on Mt) in n nt

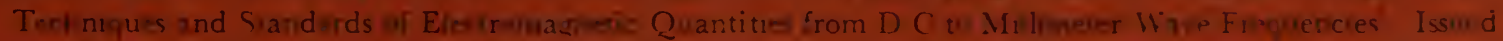

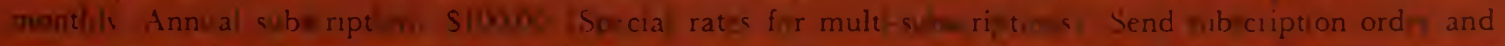

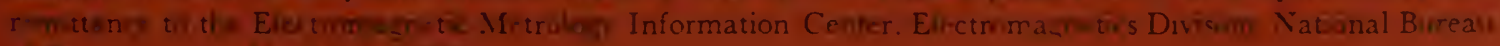

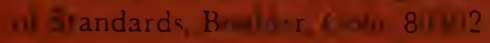


U.S. DEPARTMENT OF COMMERCE

National Bureau of Standards

Washington, D.C. 20234

OFFICIAL BUSINESS

Penalty for Private Use. $\$ 300$
POSTAGE ANO FEES PAID US DEPARTMENT OF COMMEACE COM-215

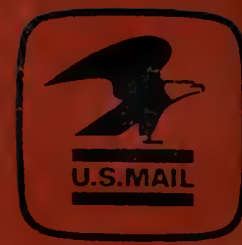

